\author{
UNIVERSIDADE DE SÃO PAULO \\ FACULDADE DE FILOSOFIA, LETRAS E CIÊNCIAS HUMANAS \\ DEPARTAMENTO DE HISTÓRIA \\ PROGRAMA DE PÓS-GRADUAÇÃO EM HISTÓRIA ECONÔMICA
}

\title{
O olhar estrangeiro em São Paulo até meados do oitocentos: relatos de viajantes ingleses e norte-americanos.
}

Tathiane Gerbovic

Dissertação apresentada ao Programa de Pós-Graduação em História Econômica do Departamento de História da Faculdade de Filosofia, Letras e Ciências Humanas da Universidade de São Paulo, para a obtenção do título de Mestre em História.

Orientador: Prof. ${ }^{\text {a }}$ Dr. ${ }^{\text {a }}$ Raquel Glezer 


\author{
UNIVERSIDADE DE SÃO PAULO \\ FACULDADE DE FILOSOFIA, LETRAS E CIÊNCIAS HUMANAS \\ DEPARTAMENTO DE HISTÓRIA \\ PROGRAMA DE PÓS-GRADUAÇÃO EM HISTÓRIA ECONÔMICA
}

TATHIANE GERBOVIC

O olhar estrangeiro em São Paulo até meados do oitocentos:

relatos de viajantes ingleses e norte-americanos. 


\section{$\underline{\text { Resumo }}$}

Ao longo do século XIX a Capitania e a Província de São Paulo foram visitadas por alguns viajantes ingleses e norte-americanos. O britânico John Mawe esteve nessas paragens entre o final de 1807 e início de 1808, em busca de minérios e de contratos comerciais. Seu conterrâneo, o comerciante Edmund Pink deixou o Rio de Janeiro durante alguns meses no ano de 1823 para percorrer a região açucareira paulista.

O pastor metodista norte-americano Daniel Parish Kidder, como missionário, desembarcou na Província em 1839 para propalar os ensinamentos evangélicos e distribuir exemplares da Bíblia. Alguns anos depois, o missionário James Cooley Fletcher, seu compatriota, esteve em São Paulo, entre junho e julho de 1855, com os mesmos fins, e para aproximar comercial e culturalmente os Estados Unidos e o Brasil.

Movido por outros objetivos, J.J. Aubertin, superintendente da Estrada de Ferro de São Paulo, durante 1865 viajou na companhia de um grupo de norte-americanos pelas regiões algodoeiras paulistas a fim de analisar o patamar de desenvolvimento desta lavoura, tendo permanecido na Província entre 1861 e 1868.

Diferentes fins impulsionaram a vinda destes viajantes para São Paulo. Apesar das disparidades, através do estudo dos relatos nota-se haver uma ótica econômica e utilitarista em comum, que agrega valores monetários e de uso aos elementos das regiões nas quais estiveram. Eles vieram munidos de um arcabouço cultural fundamentado na valorização do trabalho disciplinado, no uso racional do tempo, na maximização da produção para o aumento do lucro e na exaltação das inovações técnicas.

Os viajantes descreveram as diferentes formas de relação com o trabalho e o tempo sob o ponto de vista utilitarista, e consideraram o comportamento geral dos escravos e homens livres pobres diverso do que eles consideravam adequado, como um padrão de ociosidade.

Nossa análise está centrada na compreensão deste olhar nos escritos de viagem.

Palavras chave: viajantes ingleses e norte-americanos; ótica econômica; relatos de viagem; São Paulo; século XIX. 


\section{$\underline{\text { Abstract }}$}

Throughout the nineteenth century, the Captaincy and Province of São Paulo were visited by English and American travelers. English traveler John Mawe visited the area from the end of 1807 to the beginning of 1808, searching for ores and commercial contacts. On the other hand, English merchant Edmund Pink left Rio de Janeiro for some months in 1823 in order to visit the sugar-producing area of São Paulo.

American Methodist Episcopal theologian and writer arrived at the Province as a missionary in 1839 in order to preach and distribute copies of the Bible. Another American missionary, James Cooley Fletcher, was in São Paulo from June to July 1855, not only to preach, but also to bring United States and Brazil closer both commercially and culturally.

On the other hand, J.J. Aubertin, superintendent of the São Paulo Railway, travelled together with a group of Americans in 1865 to the cotton-producing areas of São Paulo in order to analyze the development of this crop. He remained in the Province from 1861 to 1868.

Different purposes motivated the journey of these travelers to São Paulo. In spite of their many differences, the study of their travel narratives reveals a common economic and utilitarian perspective on São Paulo, which includes monetary values and possible uses of the visited areas. Said travelers had a cultural background based on the importance of disciplined work, rational use of time, production maximization in order to increase profits and interest in technical innovations.

The aforementioned travelers described the different forms of relationship with labor and time from the utilitarian perspective, thereby considering the general behavior of the slaves and poor free men different from what they deemed adequate. Such behavior was regarded as idleness.

This study focuses on the understanding of this perspective in the travelers' journals.

Keywords: English and American travelers; economic perspective; travel narratives; São Paulo; nineteenth century. 


\section{$\underline{\text { Agradecimentos }}$}

Ao longo desta pesquisa estive cercada pelo amparo e o apoio de amigos e familiares que souberam me incentivar nos momentos oportunos e foram pacientes durante a elaboração desta dissertação. Muito obrigado, sem vocês nada disto teria sido concretizado.

Agradeço ao Conselho Nacional de Desenvolvimento Científico e Tecnológico (CNPq) pela bolsa de mestrado, que certamente possibilitou a realização deste trabalho.

Sou imensamente grata à professora Raquel Glezer por quase uma década de orientação, no mais amplo sentido do termo. Com muita sabedoria soube direcionar e moldar minhas paixões como pesquisadora, mostrando-me caminhos a serem trilhados e, em especial, foi capaz de me elucidar o que muitas vezes eu não conseguia encontrar explicação.

Aos meus familiares por estarem presentes com apoio incondicional em todas as etapas deste trabalho, pela certeza de que tudo isto um dia terminaria e pela paciência de viverem cercados por documentos, livros e mapas. Aos meus tios, tias e primos por compreenderem minha ausência.

Ao Mauro Marino Júnior, que participou de parte da pesquisa, à paciência diante de inúmeras crises e à esperança do sucesso na realização desta empreitada.

Aos professores Pedro Puntoni, Vera Ferlini e Marisa Deaecto pela leitura valiosa que me possibilitou resolver inúmeras questões e por sempre estarem generosamente dispostos a auxiliar. À Marisa, em especial pelo título dado ao Capítulo 1 - abordado pela professora Vera também, e pela presença serena e o apoio em momentos de dificuldade.

A todos "freqüentadores" da Sala I-2, em especial ao Magno Nascimento pela diagramação das imagens. Seria impossível descrever toda a ajuda que recebi de Marly Spacachieri, por isso agradeço a presença valiosa e inestimável em todos os instantes de angústia e dúvidas.

A Christina Rostworowski da Costa sou imensamente grata pela generosidade e disposição em sempre ajudar, pelas traduções ao longo destes anos e pelos apontamentos valiosos.

A Eliane Rodrigues pela amizade, o carinho e a calma em analisar situações tempestuosas. A Patrícia Cantoni pela paciência, generosidade e o carinho de sempre estar presente nos momentos de dificuldade. Seria impossível tentar dar a dimensão da minha 
gratidão pela Ana Cláudia, sempre presente, capaz de me auxiliar em todos os sentidos e que compartilhou inúmeras incertezas e esperanças ao longo destes anos. A todas vocês obrigada pelas presenças em minha vida.

Aos meus avôs Roberto Somera e Ivan Gerbovic', e minhas avós Miroslava Dragojevic' Bosko Gerbovic' e Glória Guimbute Somera agradeço infinitamente por terem me ensinado o amor ao passado, aos nossos antepassados e à Mooca. 


\section{$\underline{\text { Sumário }}$}

Introdução

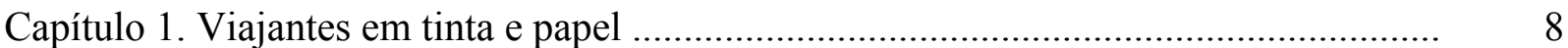

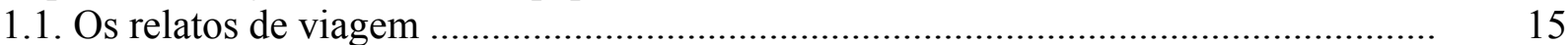

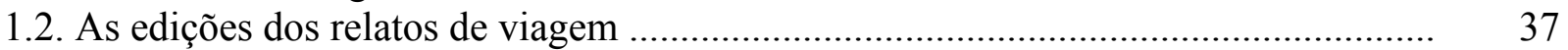

Capítulo 2. Os olhares de John Mawe, Edmund Pink e Daniel Kidder sobre São Paulo .. 43

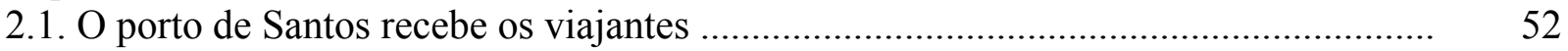

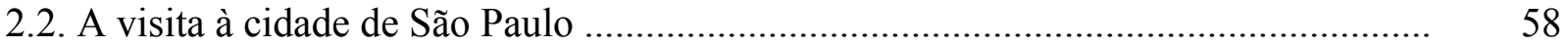

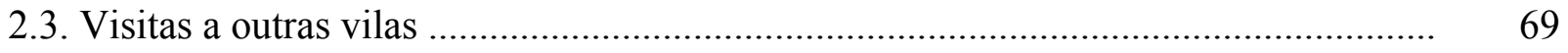

2.4. A agricultura paulista e a visita à Fábrica de Ferro de Ipanema ................................. 76

Capítulo 3. A viagem de James Cooley Fletcher e J. J. Aubertin por terras paulistas ...... 87

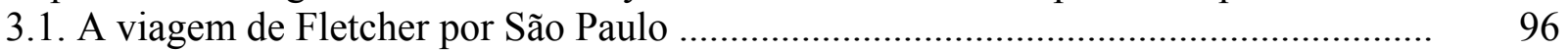

3.2. Aubertin visita o interior da Província de São Paulo ................................................. 111

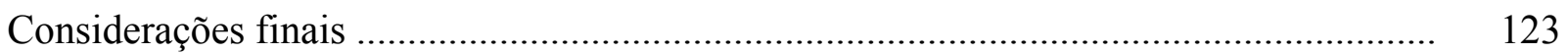

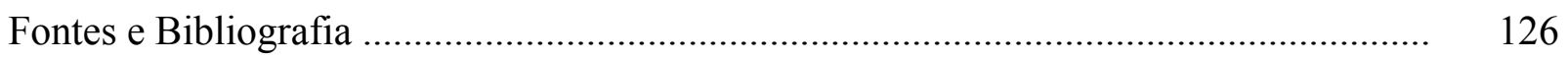

Anexos

Anexo I - O território da capitania de São Paulo, 1700 a 1853 ........................................

Fonte: Honório de Sylos. São Paulo e seus caminhos. São Paulo: McGraw-Hill, 1976, p. 7. apud. Maria Lucília Viveiros Araújo. Os caminhos da riqueza dos paulistanos na primeira metade do oitocentos. São Paulo: Hucitec/FAPESP, 2006, p. 22.

Lista de Ilustrações

Lista de Mapas

Lista de Tabelas 


\section{$\underline{\text { Lista de Ilustracões }}$}

FIGURA 1 - Edmund Pink. "Sketch of the city of St. Pauls taken on the rising ground to the right of the Road to Itu (Perfil da Cidade de São Paulo tomada da elevação à direita do Caminho para Itu)", 1823.

FONTE: Pedro Corrêa do Lago. Iconografia Paulistana: do século XIX. 2. ed. rev. e ampl. São Paulo: Capivara, 2003, p. 64-65.

FIGURA 2 - Edmund Pink. "Sketch of the City of St. Pauls taken from near the Spot where the Gallows is erected to the left of the Road from Santos as you enter de city (Perfil da Cidade de São Paulo tomado nas imediações da Forca, à esquerda do Caminho de Santos, na Estrada da Cidade)", 1823.

FONTE: Pedro Corrêa do Lago. Iconografia Paulistana: do século XIX. 2. ed. rev. e ampl. São Paulo: Capivara, 2003, p. 64-65.

FIGURA 3 - Edmund Pink. "Sketch of Peranza, the spot where the present Emperor Dom Pedro or Then Prince Regent Declaredt the Independece of Brazil (Vista de Peranza [sic], lugar onde o atual Imperador Dom Pedro ou o então Príncipe Regente declarou a Independência do Brasil)", 1823.

FONTE: Pedro Corrêa do Lago. Iconografia Paulistana: do século XIX. 2. ed. rev. e ampl. São Paulo: Capivara, 2003, p. 68.

FIGURA 4 - Edmund Pink. "View of Saint Pauls from the Rio Road (Panorama de São Paulo do Caminho para o Rio de Janeiro)", 1823.

FONTE: Pedro Corrêa do Lago. Iconografia Paulistana: do século XIX. 2. ed. rev. e ampl. São Paulo: Capivara, 2003, p. 63.

FIGURA 5 - D. P. Kidder e J. C. Fletcher. "Ponte e Serra de Cubatão", 1857.

FONTE: D. P. Kidder e J. C. Fletcher. O Brasil e os brasileiros (Esboço histórico e descritivo). São Paulo: Companhia Editora Nacional, 1941, vol. 2, p. 62.

FIGURA 6 - D. P. Kidder e J. C. Fletcher. "Esporas erroneamente colocadas pelo velho Congo", 1857.

FONTE: D. P. Kidder e J. C. Fletcher. O Brasil e os brasileiros (Esboço histórico e descritivo). São Paulo: Companhia Editora Nacional, 1941, vol. 2, p. 103.

FIGURA 7 - John Mawe. "A view of the gold washing at Jaragua near Saint Pauls (Uma vista da lavagem do ouro em Jaraguá, perto de São Paulo)”, 1812.

FONTE: Pedro Corrêa do Lago. Iconografia Paulistana: do século XIX. 2. ed. rev. e ampl. São Paulo: Capivara, 2003, p. 19. 
FIGURA 8 - John Mawe. "Costume delle Pauliste (Traje das paulistas)", 1817.

FONTE: Pedro Corrêa do Lago. Iconografia Paulistana: do século XIX. 2. ed. rev. e ampl. São Paulo: Capivara, 2003, p. 18.

FIGURA 9 - Aimé-Adrien Taunay. "Costume de S. Paul”, 1825.

FONTE: Pedro Corrêa do Lago. Iconografia Paulistana: do século XIX. 2. ed. rev. e ampl. São Paulo: Capivara, 2003, p. 75.

FIGURA 10 - Charles Landseer. "Lady of St. Pauls", 1827.

FONTE: Pedro Corrêa do Lago. Iconografia Paulistana: do século XIX. 2. ed. rev. e ampl. São Paulo: Capivara, 2003, p. 98.

FIGURA 11 - Charles Landseer. "Woman of St. Pauls", 1827.

FONTE: Pedro Corrêa do Lago. Iconografia Paulistana: do século XIX. 2. ed. rev. e ampl. São Paulo: Capivara, 2003, p. 105.

FIGURA 12 - John Mawe. "Explicação da gravura dos cristais de diamante, topázios e turmalina".

FONTE: John Mawe. Viagens ao interior do Brasil. Belo Horizonte: Ed. Itatiaia; São Paulo: Edusp, 1978, p. 184-185.

FIGURA 13 - Henry Chamberlain. “Troperos or Muleteers”, 1822. p. 56

FONTE: Pedro Corrêa do Lago. Iconografia paulistana: do século XIX. 2. ed. rev. e ampl. São Paulo: Capivara, 2003, p. 42.

FIGURA 14 - Jean-Baptiste Debret. "Pauvres Tropeiros de St. Paul”, 1823.

FONTE: Pedro Corrêa do Lago. Iconografia paulistana: do século XIX. 2. ed. rev. e ampl. São Paulo: Capivara, 2003, p. 89.

FIGURA 15 - Edmund Pink. "Vista da Cidade - Palácio da Sola", 1823.

FONTE: Pedro Corrêa do Lago. Iconografia paulistana: do século XIX. 2. ed. rev. e ampl. São Paulo: Capivara, 2003, p. 62.

FIGURA 16 - Noel-Aimé Pissis. "São Paulo - Vista tomada do Caminho de Santos", 1839.

FONTE: Pedro Corrêa do Lago. Iconografia paulistana: do século XIX. 2. ed. rev. e ampl. São Paulo: Capivara, 2003, p. 119. 
FIGURA 17 - D. P. Kidder e J. C. Fletcher. "Fazenda do Senador Vergueiro, em Ibicaba", 1857.

FONTE: D. P. Kidder e J. C. Fletcher. O Brasil e os brasileiros (Esboço histórico e descritivo). São Paulo: Editora Nacional, 1941, vol. 2, p. 119.

FIGURA 18 - D. P. Kidder e J. C. Fletcher. "Colônia Vergueiro", 1857.

FONTE: D. P. Kidder e J. C. Fletcher O Brasil e os brasileiros (Esboço histórico e descritivo). São Paulo: Editora Nacional, 1941, vol. 2, p. 121.

FIGURA 19 - Militão Augusto de Azevedo (atribuição). "Porto de Santos", 1865. p. 118 FONTE: Carlos Eugênio Marcondes de Moura. Até onde o olhar alcança. In.: Carlos Eugênio Marcondes de Moura (org.). Vida cotidiana em São Paulo no século XIX: memórias, depoimentos, evocações. São Paulo: Ateliê Editorial: Fundação Editora UNESP: Imprensa Oficial do Estado: Secretaria de Estado da Cultura, 1998, p. 398. 


\section{$\underline{\text { Lista de Mapas }}$}

MAPA 1 - John Mawe. “A Map of the Author's Route from Rio de Janeiro to Canta Gallo also to Villa Rica and thro the Centre of the Gold Mines to Tejuco, the Capital of the Diamond Mines \& District called Cerro do Frio", 1812 p. 30

FONTE: John Mawe. Viagens ao interior do Brasil. Belo Horizonte: Ed. Itatiaia; São Paulo: Edusp, 1978, p. 183.

MAPA 2 - Candido Mendes. "Mapa da Província de São Paulo (1868)". p. 36

FONTE: Candido Mendes. Atlas do Império do Brazil (1868). Rio de Janeiro: Arte \& História, Livros e Edições, 2000, mapa XVII.

MAPA 3 - "Mapa do território paulista até 1853".

FONTE: Baseado no "Mapa do Império do Brazil (1868)". In.: Candido Mendes. Atlas do Império do Brazil (1868). Rio de Janeiro: Arte \& História, Livros e Edições, 2000, mapa II.

MAPA 4 - Rufino José Felizardo e Costa. "Planta da Imperial Cidade de S. Paulo", 1841.

p. 68

FONTE: Pedro Corrêa do Lago. Iconografia paulistana: do século XIX. 2. ed. rev. e ampl. São Paulo: Capivara, 2003, p. 143.

MAPA 5 - Marisa Midori Deaecto. "Mapa da Vida Intelectual e Espiritual na Cidade de São Paulo (1837-1878)".

p. 101

FONTE: Marisa Midori Deaecto. No Império das Letras: circulação e consumo de livros na São Paulo oitocentista. Tese de doutorado. Departamento de História/Faculdade de Filosofia, Letras e Ciências Humanas. São Paulo, 2005, p. 197-198.

MAPA 6 - "Regiões paulistas percorridas por J. J. Aubertin, Drs. Gastón e Shaw e Major Mereweather em 1865".

p. 116

FONTE: Baseado em Francisco Vidal Luna e Herbert S. Klein. Evolução da sociedade e economia escravista de São Paulo, de 1750 a 1850. São Paulo: Edusp, 2005, p. 35. 


\section{$\underline{\text { Lista de Tabelas }}$}

TABELA 1 - Navios ancorados no porto do Rio de Janeiro - 1791-1810.

FONTE: Ernest Pijning. A new interpretation of contraband trade. HAHR, aug./nov. 2001, p. 82; Roberto Simonsen. História econômica do Brasil (1500-1820). São Paulo: Companhia Editora Nacional, 1969, p. 440. apud. José Jobson de Andrade Arruda. Uma colônia entre dois impérios: a abertura dos portos brasileiros. 1800-1808. Bauru (SP): EDUSC, 2008, p. 116.

TABELA 2 - Localidades visitadas por Edmund Pink - 1823.

FONTE: Tabela elaborada com base no relato do viajante Edmund Pink. A São Paulo de Edmund Pink. São Paulo: CBA, 2000, p. 81-97.

TABELA 3 - Exportação de açúcar pelo porto de Santos - 1836-1842.

FONTE: Livro das exportações da Barreira de Cubatão, entrada de Santos. apud. Maria Thereza Schorer Petrone. A lavoura canavieira em São Paulo. Expansão e declínio (17651851). São Paulo: Difusão Européia do Livro, 1968, pp. 152-167.

TABELA 4 - Volume de importação do porto de Santos para o ano comercial de 18361837.

FONTE: Daniel Pedro Müller. Ensaio d'um quadro estatístico da Província de São Paulo: ordenado pelas leis municipais de 11 de abril de 1836 e 10 de março de 1837. 3. ed. Edição fac-similar. São Paulo: Governo do Estado, 1978, p. 227.

TABELA 5 - Número de engenhos e produção de açúcar e de aguardente em Campinas $1775-1854$.

p. 71

FONTE: Maria Thereza Schorer Petrone. A lavoura canavieira em São Paulo. Expansão e declínio (1765-1851). São Paulo: Difusão Européia do Livro, 1968, p. 48.

TABELA 6 - Importação de algodão na Inglaterra (fardos).

FONTE: O Auxiliador, 1869, p. 90. apud. Alice P. Canabrava. O algodão em São Paulo: 1861-1875. 2. ed. São Paulo: Ed. T. A. Queiroz, 1984, p. 7.

TABELA 7 - Exportação de algodão (em Kgs).

FONTE: (1) Synopsis da exportação total da Província de São Paulo, pelo porto de Santos, nos últimos quinze exercicios, e estes comparados por quinquennios. A. de Brito Relatório, 1881, s.p. (2) O estado da lavoura. Diário de S. Paulo, 21-5-1874, p. 2. (3) J. A. B. Scherer. Cotton as World Power, p. 420. apud. Alice P. Canabrava. O algodão em São Paulo: 1861-1875. 2. ed. São Paulo: Ed. T. A. Queiroz, 1984, p. 301. 
TABELA 8 - Exportação do algodão da Província de S. Paulo (fardos).

FONTE: A situação da cultura do algodão em nossa Província. Diário de S. Paulo. 4-11873, p. 2. apud. Alice P. Canabrava. O algodão em São Paulo: 1861-1875. 2. ed. São Paulo: Ed. T. A. Queiroz, 1984, p. 7. 


\section{Introducão}

Com a transferência e a instalação da Corte Portuguesa e do aparato burocrático nas suas possessões sul-americanas houve a abertura dos portos às nações amigas, a partir de 1808, e ocorreu a vinda de inúmeras casas comerciais e de negociantes em busca de mercados. Devido às relações entre Portugal e Inglaterra, como esta detinha a hegemonia comercial, destaca-se a presença marcante de britânicos no cenário brasileiro. Durante sua estada, alguns desses estrangeiros percorreram o território e sobre as experiências vivenciadas escreveram os relatos de viagem.

Se era grande a vontade da Inglaterra em manter sua preponderância, os Estados Unidos ansiavam desafiar esse poderio e buscavam obter espaço nas relações comerciais com o Brasil. Concomitante à vinda dos viajantes ingleses tivemos a dos norte-americanos.

A presença da Corte no Centro-Sul acarretou a centralização política administrativa. No contexto de disputa por mercados e influência, ingleses e norteamericanos foram para a capital carioca e durante as viagens pelas vizinhanças do Rio de Janeiro alguns percorreram a Capitania e a Província de São Paulo, movidos por distintos objetivos. Seus relatos são as fontes para este trabalho.

Ao longo do século XIX São Paulo passou por profundas transformações que influenciaram os roteiros e os dados contidos nos relatos. Na primeira década do oitocentos, o atrativo era o crescimento e a expansão da lavoura canavieira e o seu papel na economia nacional. Os autores assinalaram a fundação da Academia de Direito, a vinda de forasteiros que instalaram casas comerciais na região e uma política governamental de melhoria nas estruturas da cidade com mão-de-obra estrangeira; e também os problemas do escoamento da produção paulista pelo porto de Santos, visando dinamizar o comércio com outras regiões da província e do exterior.

Os anos pós 1850 foram de rápidas mudanças. São Paulo passou a ter mais companhias nacionais e estrangeiras. O número de estrangeiros no cenário paulista passou a ser significativo, desaparecendo o assombro dos habitantes dos primeiros anos do século ao ver os forasteiros. Foram tomadas medidas efetivas de remodelação de ruas, estradas, portos e nas casas. Os hotéis passaram a existir em maior número e a não mais pedir cartas de recomendação. A produção do açúcar começou a perder força e a do café foi galgando espaço, conquistando a supremacia na lavoura e no comércio dentro e fora da Província. Durante a Guerra Civil norte-americana, entre 1861-1865, as terras paulistas foram alvo de 
investimentos britânicos em busca de mercados fornecedores de algodão e recebeu norteamericanos à procura de locais para o estabelecimento de colônias de imigrantes.

Entre finais de 1807 e início de 1808 a Capitania recebeu a visita do britânico John Mawe, vindo do Uruguai, que esteve nas minas de Jaraguá e tinha como destino o Rio de Janeiro, com a finalidade de obter contratos e contatos junto à Corte. Seu conterrâneo, o comerciante Edmund Pink esteve em São Paulo em 1823, para visitar as regiões açucareiras. Ambos escreveram relatos de suas viagens: o primeiro é autor de Viagens ao interior do Brasil, e o segundo do Diário de uma viagem através das províncias do Rio de Janeiro e São Paulo. Brasil. América do Sul.

Os norte-americanos Daniel Parish Kidder e James Cooley Fletcher também estiveram nas terras paulistas. Kidder o fez em 1839 com objetivos religiosos e relata suas experiências em Reminiscências de viagens e permanência nas Províncias do Sul do Brasil: Rio de Janeiro e Província de São Paulo: compreendendo notícias históricas e geográficas do Império e das diversas províncias. Fletcher, em 1855, veio com a mesma finalidade e para promover as relações entre o Brasil e os Estados Unidos. Adiciona suas experiências à obra de seu compatriota compondo: O Brasil e os brasileiros (Esboço histórico e descritivo).

A Guerra de Secessão nos Estados Unidos entre 1861-1865 fez cair bruscamente a produção algodoeira norte-americana, afetando diretamente o seu grande consumidor: a Inglaterra, que para evitar um colapso em seu próspero sistema industrial têxtil, enviou ingleses pelo mundo em busca de regiões capazes de produzir algodão e de se tornarem mercado exportador. Por este esforço esteve em São Paulo, de 1861 a 1868, J. J. Aubertin que em 1865 percorreu os distritos algodoeiros na companhia de um grupo de norteamericanos sulistas a procura de locais nos quais fosse possível a instalação de imigrantes norte-americanos. Os resultados foram registrados em Onze dias de viagem na Província de São Paulo com os Srs. Americanos Drs. Gaston e Shaw, e o Major Mereweather. 1865. Carta dirigida ao Illm. e Exm. Sr. Barão de Piracicaba.

Ao visitarem São Paulo, os viajantes ingleses e norte-americanos o fizeram com diferentes objetivos, mas tinham todos eles em comum o mesmo olhar: o viés econômico e utilitarista que direcionava seus interesses para os recursos naturais passíveis de serem explorados. As regiões são valorizadas por seu desempenho no comércio interno e externo da província, descritas e caracterizadas pelos resultados das ações humanas no local, isto é, 
no que concerne à agricultura: os gêneros cultivados e a extensão da lavoura, e as construções eram vistas pelas dificuldades em terem sido realizadas e pelas utilidades.

Quando tratam dos habitantes e dos estabelecimentos, os descrevem a partir dos parâmetros e modelos de suas sociedades, os quais nem sempre abarcavam os aspectos da realidade paulista. Suas balizas eram a dedicação ao trabalho disciplinado, a concepção linear do tempo, a maximização da produção, a exaltação das inovações tecnológicas, e a condenação do ócio.

As diversas edições dos relatos de viagem nos apontam para a grande receptividade deles pelos leitores europeus e norte-americanos. Em meio ao florescente mercado editorial anglo-saxão e a ampliação no número de bibliotecas na Inglaterra, os relatos eram fontes de informações que retificavam as anteriormente publicadas, e através deles era possível conhecer outras formas de habitar o mundo, e para os envolvidos nas atividades comerciais, novos campos de investimento e exploração de riquezas.

Utilizamos como fonte para citações as edições brasileiras contemporênas pela facilidade de acesso, com exceção da obra de J. J. Aubertin em que usamos o exemplar de 1866, e modernizamos a linguagem. As informações detalhadas constam no item 1.2.

Os relatos dos viajantes foram abordados sob diferentes perspectivas pela historiografia brasileira. Foram utilizados como registros precisos e verdadeiros, por terem sido elaborados por figuras participantes e observadoras in loco dos acontecimentos no passado ${ }^{1}$. Também foram explorados pelo fato dos autores serem estrangeiros, e, por não terem laços profundos com as regiões visitadas serem capazes de captar particularidades, que aos seus habitantes passariam despercebidas por serem comum ${ }^{2}$.

\footnotetext{
1 "Em 1818, além de novos navios lançados ao mar, tinham sido reparados os velhos, remodelado o almirantado, restauradas as fortalezas de Santa Cruz e Villegaignon, armazenada a artilharia pesada na ilha das Cobras, levantadas novas baterias de defesa em posições estratégicas, edificados quartéis, artilhadas as praias. Assim nos informa Luccock, e a sua informação discordante da de Maler e mais fidedigna por ser a de um homem do mundo comercial indiferente a questões exclusivamente políticas, indica que o agente diplomático via e julgava a expansão portuguesa na América, muito melhor aparelhada como estava sendo, pelo prisma deturpado do seu legitimismo e do seu europeanismo, igualmente infensos à libertação da América...”. Oliveira Lima. Dom João VI no Brasil. 4. ed. Rio de Janeiro: Topbooks, 2006, p. 564.

2 "Fizemos uma tentativa de estudá-los partindo do pressuposto de que o viajante, em sua qualidade de estrangeiro, como não fazia parte do grupo cultural visitado, tinha condições de perceber aspectos, incoerências e contradições da vida quotidiana que o habitante, ao dá-la como natural e permanente, encontrava-se incapaz de perceber. O habitante vive sua vida e reflete apenas sobre seus aspectos mais próximos, sem tomar conhecimento de muitos outros do ambiente em que se encontra". Miriam Lifchitz Moreira Leite. Livros de viagem (1803-1900). Rio de Janeiro: UFRJ, 1997, p. 9-10.
} 
Sob outro prisma, os relatos de viagem foram entendidos como uma síntese da postura do civilizado frente a uma sociedade considerada primitiva, e, as informações que foram registradas detentoras de camadas de preconceitos, representações e limitações dos viajantes em compreender a realidade observada.

José Carlos Barreiro, através da desconstrução do discurso dos viajantes, aponta o olhar pré-determinado por referências culturais denominadas por ele de modernidade. E neles analisa a resistência das classes subalternas contra a imposição do trabalho disciplinado, a concepção de propriedade privada e a idéia da natureza como um empecilho para a organização humana ${ }^{3}$.

Os referenciais e os padrões culturais dos viajantes mudaram ao longo do século, e conseqüentemente a forma como abordaram a realidade. Wilton Carlos Lima da Silva analisa como o olhar estrangeiro se alterou por meio do estudo das obras de Jean de Léry (século XVI), André João Antonil (entre os séculos XVII e XVIII) e Richard Francis Burton (século XIX). Para apreender tais transformações, os relatos foram vistos como resultado de inúmeras vertentes culturais que constituíam o cabedal do viajante, juntamente com os fatores econômicos de cada época ${ }^{4}$.

Tais perspectivas de compreensão dos relatos de viagem fazem parte do processo de "descolonização do conhecimento", isto é, nas palavras da autora do termo, Mary Louise Pratt: “... a tarefa de compreender os caminhos pelos quais o Ocidente (a) constrói seu conhecimento do mundo, alinhando às suas ambições econômicas e políticas, e (b) subjuga e absorve os conhecimentos e as capacidades de produção de conhecimento de

\footnotetext{
3 "Pela análise de um conjunto significativo de obras [os relatos de viajantes estrangeiros] abrangendo todo o século XIX e as províncias do Brasil, foi possível identificar os mecanismos pelos quais a referência cultural de um tempo, que se convencionou chamar de modernidade, presidiu sistematicamente as suas formulações sobre a sociedade brasileira e sobre as classes subalternas, em particular. [...] Por fim, a utilização do discurso dos viajantes foi importante sobretudo para demonstrar a inconsistência dos argumentos da impossibilidade de fazer a história das classes subalternas, sob o pretexto da inexistência de registros legados por esse segmento social. Reavivamos aqui aspectos fundamentais dessa memória, com base nos próprios registros deixados pelas classes dominantes". José Carlos Barreiro. Imaginário e viajantes no Brasil do século XIX: cultura e cotidiano, tradição e resistência. São Paulo: Editora UNESP, 2002, p. 224-225. [Itálico do autor]

4 "Nosso esforço de iluminar alguns pontos na história do Brasil partiu da análise dos relatos de viagem sobre as terras brasileiras de três homens que viveram em tempos distintos (Jean de Léry, no século XVI, André João Antonil, na passagem do XVII para o XVIII e Richard Francis Burton, no XIX) e nos propomos a perceber as continuidades e rupturas nas formas de apreensão e descrição do mundo natural. [...] Buscaremos identificar os relatos dos viajantes como campo fronteiriço onde se tocam a história e a literatura, em que se estruturam as representações dentro do imaginário de uma época ou cultura, dentro de um universo temporal amplo, no período colonial e no Império, em que se mesclam a exploração econômica, a criação de identidades e alteridades, e o embate de diferentes concepções culturais que não permitem serem percebidas em suas nuanças senão por meio da análise do universo simbólico, imaginário e cultural". Wilton Carlos Lima da Silva. As terras inventadas: discurso e natureza em Jean de Léry, André João Antonil e Richard Francis Burton. São Paulo: Editora UNESP, 2003, p.14-15.
} 
outros $"$. E, ainda segundo ela, a possibilidade de analisar e criticar tais obras é resultado da desmistificação do imperialismo durante o século $\mathrm{XX}^{6}$.

Em nossa pesquisa, devido às mudanças significativas ocorridas em São Paulo ao longo do século XIX, dividimos os viajantes em dois conjuntos. No primeiro arrolamos os relatos elaborados durante as viagens da primeira década do oitocentos: as de John Mawe, Edmund Pink e Daniel Kidder. No outro, os dos viajantes que percorreram as terras paulistas na segunda metade: James Fletcher e J. J. Aubertin. Com isto, além de estruturar a análise dos documentos, ficou possível apontar as permanências e mudanças na ótica destes forasteiros.

Não exploramos aqui os viajantes no período dominado pela lavoura cafeeira, pois pela quantidade deles e variedade de observações teríamos um trabalho muito maior que o dimensionado para o mestrado.

Os viajantes não somente descreveram a realidade paulista através do registro escrito, como também se valeram de aquarelas, esboços e mapas. $\mathrm{O}$ uso do material iconográfico por nós tem a finalidade de compreender melhor como os viajantes viam os novos locais visitados, e foi estudado procurando sempre vê-lo em comparação com o relato de viagem e outras imagens criadas por diferentes viajantes. Não o analisaremos detidamente, apenas indicando a reafirmação ou alteração do olhar subjetivo.

O material cartográfico apresentado foi entendido como parte do contexto de reconhecimento da Capitania e Província de São Paulo, pois concomitante às viagens e a elaboração dos relatos de viagem tivemos o mapeamento de parte do território e a produção de mapas. Este material é utilizado para identificar os caminhos percorridos pelos viajantes e entender melhor suas propostas.

Em função da organização do material documental a ser descrito e analisado, os capítulos da dissertação são os que seguem:

\section{Capitulo 1 - Viajantes em tinta e papel}

Aí abordamos a transferência da Família Real em 1808 e a conseqüência deste acontecimento no contexto das viagens pela América Portuguesa. Com a instalação da

\footnotetext{
${ }^{5}$ Mary Louise Pratt. Os olhos do império: relatos de viagem e transculturação. Bauru (SP): EDUSC, 1999, p. 15.

${ }^{6}$ Ibidem, p. 19.
} 
Corte houve a permissão régia para estrangeiros visitarem e percorrerem o território lusobrasileiro e paulista.

Devido à hegemonia econômica britânica no Brasil, foram os ingleses figuras normalmente encontradas no novo cenário. Proporcionalmente à pressão da Inglaterra em continuar com sua preponderância, existiu o desejo norte-americano em desafiar o seu poderio e se fazer presente nas relações comerciais brasileiras. Neste contexto de disputas e simultaneamente à vinda dos viajantes ingleses, destacamos a dos norte-americanos.

Dentre o conjunto dos viajantes, selecionamos John Mawe, Edmund Pink, Daniel Kidder, James Fletcher e J. J. Aubertin. Por seus relatos de viagem procuramos entender os elementos utilizados para a apresentação e descrição dos locais visitados e as experiências vividas. E identificamos a forma como se utilizaram de outras fontes para registrar suas informações, buscando mapear os seus objetivos ao percorrerem as terras paulistas.

Também tratamos das edições dos relatos de viagem com o intuito de entender a receptividade do público leitor e, as mudanças ocorridas nas obras ao longo das edições e das traduções.

Capítulo 2 - Os olhares de John Mawe, Edmund Pink e Daniel Kidder sobre São Paulo

Neste capítulo iniciamos com um breve contexto histórico paulista no início do século XIX para a análise dos relatos de Mawe, Pink e Kidder, com o objetivo de compreender como a ótica econômica utilitarista se faz presente na apresentação do porto e cidade de Santos, da cidade de São Paulo e dos seus arredores.

Concomitante aos dados sobre a capacidade paulista de crescimento, a ocorrência de recursos naturais e possibilidades de extração das riquezas, estes viajantes descrevem os entraves para o desenvolvimento de São Paulo. Buscando compreender a forma como vêem a realidade paulista, nos focamos também nos apontamentos críticos sobre a agricultura e a Fábrica de Ferro de Ipanema.

\section{Capitulo 3 - A viagem de James Cooley Fletcher e J. J. Aubertin por terras paulistas}

Neste capítulo procuramos entender os relatos de Fletcher e Aubertin, por meio do estudo das motivações que os trouxeram à São Paulo, e da forma como descrevem as regiões visitadas, em meados do século XIX. 
Nosso intuito principal foi o de mapear os parâmetros e a ótica econômica para a compreensão da realidade paulista. Inclusive, no caso de Aubertin, através dos seus apontamentos sobre a Fábrica de Ferro de Ipanema.

Nas Considerações Finais retomamos a proposta analítica e a concluímos, mostrando como a ótica econômica permeia os relatos dos viajantes selecionados em seus percursos e descrições de São Paulo nos dois momentos do século XIX, que antecedem à hegemonia da lavoura cafeeira. 


\section{Capítulo 1: Viajantes em tinta e papel}

O espaço geográfico do território hoje ocupado pelo Estado de São Paulo, enquanto Capitania ou Província, não foi dos mais explorados, diversamente do que ocorreu com outros territórios considerados pelos viajantes mais relevantes econômica e politicamente.

Há apenas algumas obras que abordam os viajantes no período pré-oitocentista. Destacamos duas: a de Affonso de Taunay intitulada Visitantes do Brasil Colonial (Séculos $X V I$ e $X V I I I)^{7}$ sobre os viajantes Oliver Van Noord, Ricardo Fleckno, De la Flotte e J. G. Semple Lisle, analisando suas incursões às possessões portuguesas na América; e o trabalho de Glória Kok O sertão itinerante: expedições da capitania de São Paulo no século XVIII, que aborda as expedições portuguesas de exploração do território, como a do sargento-mor Teotônio José Juzarte quando sob as ordens do governador da capitania de São Paulo - D. Luís Antônio de Sousa Botelho Mourão, o Morgado de Mateus - foi para a Praça do Iguatemi (próximo à atual cidade de Iguatemi/MS) com o objetivo de ocupar a fronteira do Paraguai com as terras do Mato Grosso ${ }^{8}$.

A expedição de Juzarte no dia 13 de abril de 1769 saiu de Araritaguaba, às margens do Tietê (hoje Porto Feliz), com destino ao Iguatemi, e retornou para as terras paulista em maio de 1771. Sobre este período escreveu o Diário da navegação do rio Tietê, rio Grande Paraná, e rio Gatemi em que se dá relação de todas as coisas mais notáveis destes rios, seu curso, sua distância, e de todos os mais rios que se encontram, ilhas, perigos, e de tudo o acontecido neste diário pelo tempo de dois anos e dois meses. Que principia em 10 de março de 1769, e compôs o Plano Borrão com os mapas e as imagens dos locais percorridos $^{9}$.

No Diário da navegação... descreve as embarcações utilizadas, a equipagem, o modo de navegação, os insetos e animais, as ações dos gentios, as cachoeiras perigosas e o

\footnotetext{
${ }^{7}$ Affonso de Taunay. Visitantes do Brasil Colonial. (Séculos XVI e XVIII). 2. ed. São Paulo, Rio de Janeiro, Recife, Porto Alegre: Companhia Editora Nacional, 1938.

${ }^{8}$ Glória Porto Kok. O sertão itinerante: expedições da capitania de São Paulo no século XVIII. São Paulo: Hucitec/FAPESP, 2004. Segundo a autora "este livro tem como objetivo traçar as especificidades da cultura mameluca inerentes aos habitantes da capitania de São Paulo. Para tanto, pretendo trazer à tona o cotidiano das expedições paulistas que percorreram o sertão da América portuguesa durante o século XVIII, com o fim de iluminar, por um lado, o raio de ação dos paulistas e, por outro, seu universo mental. O enfoque no mundo da experiência comum, entretanto, persegue a uma dimensão histórica, como força motriz de contínuas rupturas e articulações com os projetos de colonização encetados pela Coroa portuguesa". Ibidem, p. 15.

9 Em 2000, quando das comemorações "Brasil 500 anos", foi reunido pela primeira vez o Diário de navegação... de Teotônio José Juzarte, bem como seus mapas elaborados no Plano Borrão na edição de Jonas Soares de Souza e Miyoko Makino (orgs.). Diário de navegação. São Paulo: Edusp;Imprensa Oficial do Estado, 2000.
} 
que se perdeu na sua travessia entre homens e objetos, as fugas dos integrantes, as diferentes doenças que dizimaram grande parte do grupo e o quadro de desolação na Praça do Iguatemi.

Este estudo fixou-se em autores estrangeiros - ingleses e norte-americanos - pois tem o objetivo de verificar como a ótica econômica direcionou suas observações e seus relatos sobre a realidade paulista oitocentista.

Em 1808 com a transferência da Coroa Portuguesa para a América e a abertura dos portos às nações amigas houve a ampliação e intensificação das atividades econômicas nos territórios luso-americanos. Inúmeras casas comerciais estrangeiras se instalaram em busca de lucro em tão extenso território, assim como indivíduos em atividades como cônsules, diplomatas, militares, naturalistas, religiosos e outros. A hegemonia britânica nas relações comerciais brasileiras no período foi marcada pela busca de soluções para a crise em que vivia, decorrente das dificuldades da indústria devido à restrição de importações e exportações com o Bloqueio Continental e às difíceis relações com os Estados Unidos.

A colônia portuguesa que passou a ser a sede da monarquia, a Metrópole, tornou-se um ponto fundamental para o escoamento da produção e abertura de novos mercados com a marcante presença de ingleses, em especial no ramo comercial, tanto no Rio de Janeiro como em todo território luso-americano. Segundo Marco Morel, "era o momento de expansão do Império Britânico que passa também a incorporar sob seu manto imperial territórios independentes politicamente, mas cada vez mais subordinados do ponto de vista econômico" ${ }^{\prime \prime}$.

Sobre a influência britânica no Brasil escreve Olga Pantaleão: "A penetração inglesa marcará o século XIX brasileiro. Predominam os ingleses em nosso mercado: trazendo mercadorias de toda a espécie, levam matérias-primas, como algodão, e produtos agrícolas ou derivados da pecuária. Investem grandes capitais: em títulos de empréstimos do governo, em companhias mineiras, em estradas de ferro e em inúmeras outras empresas. Influem em todos os aspectos da vida brasileira. [...] [e] também intelectualmente [...] O século XIX, sobretudo em sua primeira metade, foi assim, no

\footnotetext{
${ }^{10}$ Marco Morel. As transformações dos espaços públicos. Imprensa, atores políticos e sociabilidade na Cidade Imperial (1820-1840). São Paulo: Ed. Hucitec, 2005, p. 51.
} 
Brasil o século inglês por excelência. E tudo isso começou com a chegada da família real portuguesa" ${ }^{\prime 1}$.

A hegemonia inglesa no Brasil foi desafiada pelos Estados Unidos da América ao longo do século $\mathrm{XIX}^{12}$. Como destaca Fernanda de Almeida: "se a decisão da GrãBretanha no sentido de tutelar essa expressiva porção da América era firme, também o eram a vontade e a pertinácia com que os norte-americanos procuravam desafiar essa tutela,"13.

Antes de 1808, Portugal e Estados Unidos tentaram estabelecer tratados comerciais que não foram concretizados. Em 1802, o Departamento de Estados norte-americano, por recomendação de Thomas Jefferson, extinguiu sua representação em Portugal visando poupar recursos, mas após a chegada da Família Real ao continente americano o governo republicano reatou as relações diplomáticas, e Jefferson em 4 de março de 1808 emitiu credenciais para Henry Hill, comerciante de Nova York estabelecido na Bahia, atuar como cônsul em Salvador, sendo enviado ao Rio de Janeiro para cumprimentar a Corte portuguesa.

No dia 7 de março de 1809 Hill foi nomeado efetivamente pelo Senado norteamericano, juntamente com Thomas Sumter Jr. designado para ocupar o posto de ministro na capital carioca ${ }^{14}$. A ação imediatista do governo norte-americano em designar agentes diplomáticos para o país deve-se tanto ao interesse comercial no novo e promissor mercado, quanto pela incômoda presença de uma monarquia européia no continente americano $^{15}$.

\footnotetext{
${ }^{11}$ Olga Pantaleão. A presença inglesa. In.: Sérgio Buarque de Holanda (org.). História Geral da Civilização Brasileira. O Brasil monárquico: O processo de emancipação. 2. ed. São Paulo: Difusão Européia do Livro, 1965 , vol. 1, p. 64-65.

12 "Ao longo do século XIX, a política externa brasileira foi obrigada a se adaptar, sucessivamente, à hegemonias britânica e americana. Sob a influência direta da primeira, o Império renunciou à projeção africana, conformando-se ao horizonte sul-americano, assimilando o Atlântico como fronteira oriental e, conseqüentemente, aprofundando o seu 'destino continental'. O advento da polaridade dos Estados Unidos condicionou a reorientação diplomática concluída por Rio Branco, cuja interpretação do pan-americanismo enfatizava a busca de uma parceria privilegiada capaz de conferir ao Brasil a posição dominante na esfera da América do Sul". Demétrio Magnoli. O corpo da pátria: imaginação geográfica e política externa no Brasil (1808-1912). São Paulo: Ed. UNESP; Moderna, 1997, p. 295.

${ }_{13}$ Antonia Fernanda Pacca de Almeida. Desafio americano à preponderância britânica no Brasil: 18081850. Tese de doutorado. Departamento de História/Faculdade de Filosofia, Letras e Ciências Humanas/ Universidade de São Paulo, 1970, p. 49.

${ }^{14}$ Antonia Fernanda de Almeida Wright. Brasil - Estados Unidos. In.: Sérgio Buarque de Holanda (org.). História Geral da Civilização Brasileira. O Brasil Monárquico: declínio e queda do império. 5. ed. Rio de Janeiro: Bertrand Brasil, 1995, p. 173; Luiz Alberto Moniz Bandeira. Presença dos Estados Unidos no Brasil. Rio de Janeiro: Civilização Brasileira, 2007, pp. 49-50.

15 "Não há, nesse quadro geral suficiente apoio para dar-se a devida ênfase ao papel desempenhado pelo Brasil nas cogitações mais óbvias da política exterior americana, principalmente a partir da década do
} 
Após $1808^{16}$, viajantes de diferentes nacionalidades desembarcaram nos portos luso-brasileiros. No mesmo ano da chegada da Família Real, o comerciante inglês John Luccock se instalou no Rio de Janeiro onde viveu até 1818 , com breves interrupções ${ }^{17}$. Gustavo Beyer, médico sueco, visitou a Bahia, Rio de Janeiro e São Paulo em $1813^{18}$.

O naturalista francês Auguste de Saint-Hilaire esteve no Brasil em duas ocasiões; a primeira em 1816 - por influência do Conde de Luxemburgo - e visitou o Rio de Janeiro, Espírito Santo, Minas Gerais, Goiás, Mato Grosso, São Paulo, Paraná, Santa Catarina e Rio Grande do Sul. E na segunda viagem, em 1822, andou pelo Rio de Janeiro, Minas Gerais e São Paulo ${ }^{19}$. Carl von Martius e Johann von Spix visitaram o Brasil de 1817 a $1820^{20}$.

\footnotetext{
'destino manifesto' [1823]. Isso porque os próprios fatos mostram o 'Império' Americano como o chama Alstyne, crescendo então mais a volta de si mesmo. Tudo leva a crer que seus homens de Estado, mais do que nunca olhassem naquela época para dentro do país. É somente consultando a documentação diplomática referente ao Brasil, nesse período, que se pode perceber a continuidade da atividade política norte-americana; talvez mais cautelosa após 1840, mas, nem por isso, menos objetiva e eficiente ao aproveitar toda e qualquer possibilidade que se apresentasse para desafiar o poderio europeu aqui representado de maneira mais agressiva pela preponderância da Grã-Bretanha”. Antonia Fernanda Pacca de Almeida. Desafio americano..., $o p$. cit., p. 65. "As relações oficiais entre os Estados Unidos e o Império do Brasil estabeleceram-se num clima de dubiedade e suspeita. As raízes da desconfiança cresciam na diferença dos regimes e de estrutura das duas sociedades. Os Estados Unidos consideravam o Império uma anomalia na América. O Império via nos Estados Unidos um foco de subversão". Luiz Alberto Moniz Bandeira. Presença dos Estados Unidos..., op. cit., p. 101.

16 "A não ser no Quinhentos e, até certo ponto, no Seiscentos, nunca o nosso país parecera tão atraente aos geógrafos, aos naturalistas, aos economistas, aos simples viajantes, como aqueles anos que imediatamente se seguem à instalação da Corte portuguesa no Rio e à abertura dos portos ao comércio internacional. $\mathrm{O}$ fato acha em si mesmo sua explicação. A contar de 1808 ficam enfim suspensas as barreiras que, ainda pouco antes, motivaram o célebre episódio daquela ordem régia mandando atalhar a entrada em terras da Coroa de Portugal de 'certo Barão de Humboldt, natural de Berlim', por parecer suspeita a sua expedição e sumamente prejudicial aos interesses políticos do Reino. De modo que a curiosidade tão longamente sofreada pode agora expandir-se sem estorvo e, não poucas vezes, com o solícito amparo das autoridades. Nesses poucos anos foi como se o Brasil tivesse amanhecido de novo aos olhos dos forasteiros, cheio da graça milagrosa e das soberbas promessas com que se exibira aos seus mais antigos visitantes. Num intervalo de cerca de dois séculos, a terra parecera ter perdido, para portugueses e luso-brasileiros, muito de sua primeira graça e gentileza, que agora the vinha restituída...”. Sérgio Buarque de Holanda. A herança colonial: sua desagregação. In.: Sérgio Buarque de Holanda (org.). História Geral da Civilização Brasileira. O Brasil monárquico: O processo de emancipação..., op. cit., vol. 1, p. 12-13. Para Valter Pires Pereira "a política de restrições coloniais proibia viagens e migrações de estrangeiros para a colônia, a exemplo da não autorização ao pedido de Humboldt para viagem de pesquisa pelo interior do Brasil. A mudança ocorreu a partir da expedição do Decreto de 25 de novembro de 1808 , que permitirá inclusive a concessão de sesmarias a estrangeiros que fixarem residência no Brasil, como forma de contribuir para o desenvolvimento da agricultura". Valter Pires Pereira. A idéia de progresso na formação social brasileira: das academias literárias à Sociedade Auxiliadora da Indústria Nacional. Tese de doutorado. Departamento de História/Faculdade de Filosofia, Letras e Ciências Humanas/Universidade de São Paulo, 1999, p. 199.

${ }^{17}$ John Luccock. Notas sobre o Rio de Janeiro e partes meridionais do Brasil. Trad. Milton da Silva Rodrigues. Belo Horizonte: Ed. Itatiaia; São Paulo: Edusp, 1975.

${ }^{18}$ Gustavo Beyer. Viagem a São Paulo no verão de 1813. Trad. Alberto Loëfgren. 2. ed. Campinas (SP): PucCampinas, 1992.

${ }^{19}$ Sobre sua visita a São Paulo. Primeira viagem: Auguste de Saint-Hilaire. Viagem à Província de São Paulo. Trad. Regina Reis Junqueira. Belo Horizonte: Ed. Itatiaia; São Paulo: Edusp, 1976. E Segunda viagem do Rio de Janeiro a Minas Gerais e a São Paulo, 1822. Trad. Vivaldi Moreira. Belo Horizonte: Ed. Itatiaia; São Paulo: Edusp, 1974.
} 
Em 1826 partiu da França Alcide Dessalines D’Orbigny que percorreu o Brasil, as Missões do Paraguai e o Uruguai ${ }^{21}$. O barão Georg Heinrich von Langsdorff visitou o Brasil em algumas ocasiões, inclusive chefiando uma expedição, em companhia de sua esposa Wilhelmine Langsdorff ${ }^{22}$. Entre 1833 a 1835 o naturalista inglês Charles James Fox Bunbury esteve no Rio de Janeiro, Minas Gerais e região do Prata ${ }^{23}$. George Gardner, naturalista escocês, visitou o Rio de Janeiro seguindo para os atuais Norte, Nordeste e Sudeste entre 1836 a $1841^{24}$.

Na década de 1850, Thomas Ewbank, norte-americano, esteve no Rio de Janeiro ${ }^{25}$. O médico alemão Robert Avé-Lallemant no ano de 1858 viajou por São Paulo, Paraná e Santa Catarina ${ }^{26}$. No mesmo período Johann Jakob von Tschudi viajou pelas províncias do Rio de Janeiro e São Paulo ${ }^{27}$. Em 1853 e 1868 William Hadfield esteve no Rio de Janeiro, São Paulo e norte do país ${ }^{28}$. No ano de 1865, o casal Elizabeth Cary e Luiz Agassiz deixou Nova York em uma expedição científica, chefiada por ele, que percorreu o Rio de Janeiro seguindo para o norte do Brasil ${ }^{29}$.

Em 1865 Sir Richard Francis Burton foi mandado para Santos na condição de cônsul e, durante suas férias incursionou pelo Rio de Janeiro e Minas Gerais ${ }^{30}$. De 1870 a 1881, com algumas interrupções, o naturalista norte-americano Herbert Smith com

\footnotetext{
${ }^{20}$ Carl von Martius e Johann von Spix. Viagem pelo Brasil. 1817-1820. Trad. Lúcia Furquim Lahmeyer. 2. ed. São Paulo: Melhoramentos, s/d.

${ }^{21}$ Alcide Dessalines D’Orbigny. Viagem pitoresca através do Brasil. Trad. David Jardim. Belo Horizonte: Ed. Itatiaia; São Paulo: Edusp, 1976.

${ }^{22}$ Danuzio Gil Bernardino da Silva (org.). Os diários de Langsdorff. Trad. Márcia Egg e outros. Rio de Janeiro: Fiocruz; Campinas (SP): Associação Internacional de Estudos Langsdorff, 1997. (Vol. 1. Rio de Janeiro e Minas Gerais - 8 de maio de 1824 a 17 de fevereiro de 1825; vol. 2. 26 de agosto de 1825 a 22 de novembro de 1826).

${ }^{23}$ Charles James Fox Bunbury. Viagem de um naturalista inglês ao Rio de Janeiro e Minas Gerais: 18331835. Trad. Helena Garcia de Souza. Belo Horizonte: Ed. Itatiaia; São Paulo: Edusp, 1981.

${ }^{24}$ George Gardner. Viagem ao interior do Brasil, principalmente nas províncias do Norte e nos distritos do ouro e do diamante durante os anos de 1836-1841. Trad. Milton Amado. Belo Horizonte: Ed. Itatiaia; São Paulo: Edusp, 1975.

${ }^{25}$ Thomas Ewbank. A vida no Brasil; ou, Diário de uma visita à terra do cacaueiro e das palmeiras, com um apêndice contendo ilustrações das artes sul-americanas antigas. Trad. Jamil Almansur Haddad. Belo Horizonte: Ed. Itatiaia; São Paulo: Edusp, 1976.

${ }^{26}$ Robert Avé-Lallemant. Viagens pelas províncias de Santa Catarina, Paraná e São Paulo (1858). Trad. Teodoro Cabral. Belo Horizonte: Ed. Itatiaia; São Paulo: Edusp, 1980.

${ }^{27}$ Johann Jakob von Tshudi. Viagens às províncias do Rio de Janeiro e São Paulo. Trad. Eduardo de Lima Castro. Belo Horizonte: Ed. Itatia; São Paulo: Edusp, 1980.

${ }^{28}$ William Hadfield. Brazil and the River Plate in 1868: by William Hadfield, showing the progress of those countries since his former visit in 1853. London: Bates, Hendy and CO., 1869.

${ }^{29}$ Luiz e Elizabeth Agassiz. Viagem ao Brasil: 1865-1866. Trad. João Etienne Filho. Belo Horizonte: Ed. Itatiaia; São Paulo: Edusp, 1975.

${ }^{30}$ Sir Richard Francis Burton. Viagem do Rio de Janeiro a Morro Velho. Trad. David Jardim Júnior. Belo Horizonte: Ed. Itatiaia; São Paulo: Edusp, 1976; e Viagem de canoa de Sabará ao Oceano Atlântico. Trad. David Jardim Júnior. Belo Horizonte: Ed. Itatiaia; São Paulo: Edusp, 1977.
} 
objetivos científicos visitou inúmeras regiões do Brasil ${ }^{31}$. O naturalista John Ball percorreu São Paulo, Rio de Janeiro, Bahia, Pernambuco e Fernando de Noronha em finais de $1885^{32}$. E dois anos antes da Proclamação da República, o ex-cônsul norte-americano Christopher Andrews visitou o Rio de Janeiro e São Paulo ${ }^{33}$.

Devido à supremacia comercial e política da Inglaterra no Brasil, os viajantes desta nacionalidade se destacam em quantidade entre os das outras nações, percorrendo de norte a sul as terras luso-brasileiras ${ }^{34}$. Entretanto, ao longo do século XIX, no contexto das disputas comerciais dos Estados Unidos e Grã-Bretanha ao redor do mundo ${ }^{35}$, chegaram concomitante aos viajantes ingleses, os norte-americanos, que incursionaram pela colônia portuguesa na América, e depois Brasil, e pela Capitania e Província de São Paulo ${ }^{36}$.

Com a instalação da Coroa e de seu aparato burocrático no Rio de Janeiro ocorreu o processo de interiorização da metrópole com a Corte a lançar os fundamentos do novo Império e chamar "para si o controle e a exploração das outras 'colônias' do continente"37.

\footnotetext{
${ }^{31}$ Herbert H. Smith. Do Rio de Janeiro a Cuyabá. Notas de um naturalista por Herbert Smith (Com capitulo de Carlos von den Steinen sobre a capital de Matto Grosso). São Paulo: Companhia Melhoramentos/Weiszflog Irmãos Incorporados, 1922.

${ }^{32}$ John Ball. Notes of a naturalist in South America. London: Kegan Paul, Trench \& CO., 1887.

${ }^{33}$ C. C. Andrews. Brazil. Its conditions and prospects. New York: D. Applenton and Company, 1887.

${ }^{34}$ Cândido de Mello-Leitão remonta ao Setecentos as facilidades dos ingleses em penetrar no território lusobrasileiro. Em suas palavras: "Para os ingleses desde o século XVIII fizera Portugal uma exceção ao ciúme com que furtava o Brasil a alheias vistas, e quando os viajantes de outras nações apenas tocavam a medo em alguns portos, vemos os ingleses, a convite do próprio Governo da metrópole, penetrarem até a recatadíssima região de mineração de ouro. Talvez que tais facilidades desinteressassem a coroa de Inglaterra, e, contrastando com as missões científicas alemães, austríacas, francesas e russa nenhuma vemos mandada pelo Governo Britânico". C. de Mello-Leitão. A biologia no Brasil. São Paulo: Companhia Editora Nacional, 1937, p. 157-158.

35 “O predomínio da Grã-Bretanha manifestou-se essencialmente na sua destacada influência diplomática e na sua posição comercial hegemônica, jamais no controle territorial direto sobre os Estados sul-americanos. $\mathrm{O}$ papel que ela desempenhou foi o de promover o isolamento das Américas em relação às potências continentais européias. Assim, ironicamente, a frota britânica cumpriu a função de instrumento efetivo da Doutrina Monroe [1823], afiançando a independência política das nações do Novo Mundo". Demétrio Magnoli. O corpo da pátria..., op. cit., p. 133-134.

36 "Até 1822 foi afirmando-se o significado atual de paulistano. Na proclamação de 8 de setembro Dom Pedro, príncipe regente, dirige-se aos honrados paulistanos e no texto da mesma invoca os amigos paulistanos. A Capitania de São Paulo não recebeu o seu primeiro governador capitão-general Rodrigo Cesar de Meneses senão a 5 de setembro de 1721 e, desprezando-se a perda oficial que não implicou a designação usual de capitania entre 1748 e 1765 , somente passou a ser de fato uma província desde 23 de junho de 1821 e, de direito, desde a Constituição de 25 de março de 1824. Em vão muitos repetem que a mesma carta régia, de 15 de dezembro de 1815, que elevou o Brasil a Reino Unido, mudou para o de província o nome das capitanias. Não há palavra nenhuma a respeito no documento malcitado". Aluísio de Almeida. Vida cotidiana da Capitania de São Paulo (1722-1822). Excertos de uma Obra Completa. In.: Carlos Eugênio Marcondes de Moura (org.). Vida cotidiana em São Paulo no século XIX: memórias, depoimentos, evocações. São Paulo: Atêlie Editorial: Fundação Editora da Unesp: Imprensa Oficial do Estado: Secretaria de Estado da Cultura, 1998, p. 9.

${ }^{37}$ Maria Odila Leite da Silva Dias. A interiorização da metrópole e outros estudos. 2. ed. São Paulo: Alameda, 2005, p. 22.
} 
A centralização político-administrativa no Centro-Sul do Brasil trouxe inúmeros viajantes para a capital carioca que também visitaram as terras paulistas.

No que tange à Província de São Paulo, segundo Denise de Moura a proximidade com o Rio de Janeiro "refletiu positivamente na economia paulista de animais, açúcar e alimentos, pois [a presença da Família Real] ampliou o mercado consumidor fluminense ${ }^{, 38}$. Aluísio de Almeida também destaca esta relação: "Tomada a Capitania em conjunto, não só no renovamento do ciclo do açúcar houve exportação da Europa, mas sempre houve excedentes da lavoura de subsistência, exportados para o Rio, Bahia e Recife, por exemplo, a mandioca que se enviava de Paranaguá e Cananéia a Santos e daí para o Rio e para as embarcações que aportavam, inclusive navios europeus "39.

Os viajantes ingleses e norte-americanos estiveram nas terras paulistas e, sobre suas viagens escreveram relatos que tratam dos inúmeros aspectos da organização política, social, cultural e econômica das localidades visitadas. Dentre esses estrangeiros, nossa pesquisa foca os relatos dos ingleses: John Mawe: Viagens ao interior do Brasil e Edmund Pink: Diário de uma viagem através das províncias do Rio de Janeiro e São Paulo. Brasil. América do Sul. Os norte-americanos: Daniel Parish Kidder: Reminiscências de viagens e permanência nas Províncias do Sul do Brasil: Rio de Janeiro e Província de São Paulo: compreendendo notícias históricas e geográficas do Império e das diversas províncias e James Cooley Fletcher e Daniel Parish Kidder: O Brasil e os brasileiros. Esboço histórico e descritivo. E o relato de J. J. Aubertin Onze dias de viagem na Província de São Paulo com os Srs. Americanos Drs. Gaston e Shaw, e o Major Mereweather. 1865. Carta dirigida ao Illm. e Exm. Sr. Barão de Piracicaba, sobre sua viagem à São Paulo em companhia de norte-americanos.

\footnotetext{
${ }^{38}$ Denise Aparecida Soares de Moura. Economia, cultura e sociedade em São Paulo (1808-1850). Tese de doutorado. Departamento de História/Faculdade de Filosofia, Letras e Ciências Humanas/Universidade de São Paulo, 2002, p. 14.

${ }^{39}$ Aluísio de Almeida. Vida cotidiana da Capitania de São Paulo..., op. cit., p. 35. Sobre esta questão, Maria Lucília Viveiros Araújo reitera as colocações de Denise de Moura e Aluísio de Almeida e afirma: "D. João VI escolheu o Rio de Janeiro como sede do governo: a proximidade da Corte e a experiência dos paulistas com a venda de tropas e alimentos abriram novos horizontes ao comércio paulista". Maria Lucília Viveiros de Araújo. Os caminhos da riqueza dos paulistanos na Primeira Metade do Oitocentos. São Paulo: Hucitec/FAPESP, 2006, p. 28.
} 


\subsection{Os relatos de viagem}

O relato de viagem é a materialização das experiências vividas pelos ingleses e norte-americanos após suas viagens na Capitania e depois Província de São Paulo. O fato de terem vivenciado as situações expostas e visitado as terras descritas dota a eles e as suas obras com o estatuto da veracidade ${ }^{40}$ e os capacita a tratar das regiões percorridas com confirmado conhecimento.

O inglês John Mawe desembarcou em 1804 no Rio da Prata, e em Montevidéu foi capturado juntamente com seu navio e sua carga. No ano de 1807 foi posto em liberdade, e logo iniciou sua viagem com destino ao Rio de Janeiro, munido de uma carta de apresentação fornecida pelo embaixador português em Londres, irmão do Conde de Linhares. Na colônia portuguesa passou por Santa Catarina e daí para São Paulo, onde interrompeu sua estada com a notícia da chegada da Família Real, seguindo em direção à capital. Seu relato Viagens ao interior do Brasil (1812), patrocinado pelo Príncipe Regente, consiste em suas observações associadas às sugestões de melhorias nos locais visitados, baseado no que viu e vivenciou, conforme suas palavras:

"A Sua Alteza Real O Príncipe Regente de Portugal, Príncipe do Brasil, etc. etc. etc.

Senhor

Com a sanção de Vossa Alteza Real realizei viagens pelos seus domínios do Brasil, e delas é a narrativa que se segue: obedecendo à ordem que Vossa Alteza se dignou dar-me, quando parti do Rio de Janeiro, submeto-a, agora, ao Público.

Com imparcialidade, e livre de qualquer preconceito, tentei fazer um relato claro e fiel do que vi. Ao descrever as condições atuais da mineração e da agricultura nos seus domínios, tomei a liberdade de sugerir alguns melhoramentos, que, na minha modesta opinião, contribuiriam para aumentar a renda de Vossa Alteza Real e multiplicar os recursos do país. Estes foram os pontos principais em que baseei minha esperança de que o trabalho, apesar de suas imperfeições, fosse julgado digno de ser patrocinado por um Príncipe, cuja fidelidade consiste em assegurar a de seus súditos" ${ }^{\text {"41 }}$.

O viajante aponta os objetivos do seu relato nos seguintes termos:

"As observações feitas nessas viagens, sobre o país e seus habitantes, constituem a parte principal deste volume, ora oferecido ao público.

\footnotetext{
40 "O discurso dos viajantes é um esforço de dar realidade e inteligibilidade ao que se vê através de uma espessa camada das representações, em que versões são superpostas a fatos, evidenciando como as culturas estabelecem identidades e alteridades, aproximações e afastamentos, hierarquias e desordens". Wilton Carlos Lima da Silva. As terras inventadas..., op. cit., p. 54.

${ }^{41}$ John Mawe. Viagens ao interior do Brasil. Trad. Selena Benevides Viana. Belo Horizonte: Itatiaia; São Paulo: Edusp, 1978, p. 21.
} 
Quaisquer que sejam as falhas ou os méritos por ela apresentados, relacionam-se com os assuntos atuais, extremamente interessantes, quer sob o aspecto político, quer sob o ângulo comercial. Elas têm por fim revelar o desenvolvimento dos recursos físicos de uma colônia que, através de recentes transformações, está prestes a constituir um império e, em parte, retratar o caráter de uma nação que é e sempre foi a aliada mais fiel da Grã-Bretanha"42.

Outro viajante, o pastor metodista norte-americano Daniel Parish Kidder também utiliza os conhecimentos adquiridos in loco, para criticar um artigo sobre o Brasil na "M'Culloch's Universal Gazetteer":

"Fomos ao mesmo tempo tomados de surpresa e aborrecimento ao perceber que o artigo estava crivado de erros. Dificilmente se concebe como foi possível condensar em tão pequeno espaço, tamanha cópia de inexatidões. Tentar a enumeração de tais deslizes, seria perda de tempo. Deixá-los passar sem protesto, principalmente os mais clamorosos, seria um ato de injustiça para com aqueles que desejam ser corretamente informados. [...] Também dificilmente se pode desculpar que se encarregue alguém, sem ter conhecimento pessoal do grande império brasileiro, da elaboração de artigo destinado à publicidade como o trabalho a que nos referimos" ${ }^{\prime 43}$.

Esta questão é preponderante no relato de Kidder intitulado Reminiscências de viagens e permanência nas Províncias do Sul do Brasil: Rio de Janeiro e Província de São Paulo: compreendendo notícias históricas e geográficas do Império e das diversas províncias (1845). Segundo suas anotações, o objetivo de sua obra é informar aos norteamericanos alguns aspectos da realidade brasileira, baseado na observação empírica das paragens, associada ao estudo de obras e documentos sobre o Brasil. Em suas palavras:

"Até hoje não se havia impresso nos Estados Unidos um livro que tratasse exclusivamente do Brasil. Sobre nenhuma outra nação de igual tamanho e importância são tão restritas as fontes de informação de que dispomos. Não são recentes os trabalhos existentes em língua inglesa sobre esse país, nem tão pouco sabemos de algum cujo autor tenha visitado mais de duas ou três das dezoito províncias do Império. Tais circunstâncias, aliadas às solicitações recebidas de diversas procedências, induziram-nos a publicar, ao lado de alguns apontamentos históricos e geográficos, nossas reminiscências relativas a quase dois anos e meio de residência e viagens através dessa interessante região sulamericana" 44 .

\footnotetext{
${ }^{42}$ John Mawe. Viagens ao interior do Brasil..., op. cit., p. 23.

${ }^{43}$ Daniel Parish Kidder. Reminiscências de viagens e permanência nas Provincias do Sul do Brasil: Rio de Janeiro e Províncias de São Paulo: compreendendo notícias históricas e geográficas do Império e das diversas provincias. Trad. Moacir Vasconcelos. Belo Horizonte: Itatiaia; São Paulo: Edusp, 1980, p. 291293.

${ }^{44}$ Ibidem, p. 17.
} 
O mesmo objetivo é retomado em O Brasil e os brasileiros. Esboço histórico e descritivo (1857). Este relato é o resultado da viagem do também pastor metodista norteamericano James Cooley Fletcher, que acrescenta à obra de Kidder, Reminiscências de viagens..., dados sobre sua permanência no Brasil nas décadas de 1850-60, com breves intervalos, tendo visitado São Paulo em 1855. Na obra, escrita a quatro mãos ${ }^{45}$, propõem:

"Não seria exagero dizer que a grande maioria dos leitores está mais inteirada sobre a China e a Índia do que sobre o Brasil. Quão poucos sabem que existe, no distante hemisfério meridional, uma estável monarquia constitucional, uma florescente nação, que ocupa um território de área maior que a dos Estados Unidos, e que os descendentes dos portugueses ocupam na América do Sul a mesma posição relativa que os descendentes dos ingleses na América do Norte. Quão poucos os protestantes que conhecem o fato de que, no território do Brasil, foi a religião protestante pela primeira vez proclamada no Continente Ocidental! A presente obra escrita por duas pessoas que têm vinte anos de experiência no Império do Brasil, pretende traçar um retrato fiel da história do país, e, pela narrativa dos incidentes relacionados com as viagens empreendidas e durante a residência dos autores na Terra de Santa Cruz, tornar conhecidos os costumes, os hábitos e o adiantamento do povo mais progressivo que vive ao sul do Equador" ${ }^{46}$.

O objetivo de John Mawe de tornar conhecidos os recursos físicos e as transformações no Brasil se assemelha aos desígnios dos relatos de Kidder e Fletcher quando pretendem abordar os avanços e progressos nas terras brasileiras ${ }^{47}$. Mas os últimos consideram-no um país novo, e com isto definiram seus parâmetros comparativos do seguinte modo:

"Deve-se ter sempre em mente a origem dos brasileiros, que o Brasil é um país novo entre os demais países do mundo, e que a única forma verdadeira de comparar o Brasil não é medir o seu progresso pelos

\footnotetext{
45 "Embora o presente volume seja o resultado de um trabalho comum, o desejo de maior uniformidade fez com que o primeiro dos autores [Kidder] entregasse ao Segundo J. C. Fletcher a sua contribuição, permitindo que este usasse o seu nome na terceira pessoa do singular. A soma de trabalho devida a cada uma das duas penas é mais igual do que à primeira vista pode parecer". D. P. Kidder e J. C. Fletcher. O Brasil e os brasileiros (esboço histórico e descritivo). Trad. Elias Dolianiti. São Paulo: Editora Companhia Nacional, 1941 , vol. 1, p. XII.

${ }^{46}$ Ibidem, p. XI-XII.

${ }^{47}$ A temática dos melhoramentos ocorridos no território luso-brasileiro, tal como encontrado nos viajantes, se faz presente na fala de D. Pedro II ao encerrar a Assembléia Geral de 11 de setembro de 1859, na ocasião da sua visita ao Norte e Nordeste do Brasil, quando destaca o seu empenho em aprimorar moral e materialmente as províncias brasileiras: "Para melhor conhecer as províncias do meu Império, cujos melhoramentos morais e materiais são o alvo de meus constantes desejos e dos esforços do meu governo, decidi visitar as que ficam ao Norte da do Rio de Janeiro, sentindo a estreiteza do tempo que medeia entre as sessões legislativas me obrigue a percorrer as províncias do Espírito Santo, Bahia, Sergipe, Alagoas, Pernambuco e Paraíba, reservando a visita das outras para mais tarde". Dom Pedro II. Imperador do Brasil. Viagens pelo Brasil: Bahia, Sergipe e Alagoas (1859-1860). 2. ed. Rio de Janeiro: Bom Texto; Letras \& Expressões, 2003, p. 25.
} 
Estados Unidos, Inglaterra ou França, mas sim pelo das demais nações de raça latina na América" 48 .

O olhar sobre as potencialidades econômicas paulistas também se faz presente no relato de J. J. Aubertin intitulado Onze dias na Província de São Paulo com os Srs. Americanos Drs. Gaston e Shaw, e o Major Mereweather. 1865. Carta dirigida ao Illm. e Exm. Sr. Barão de Piracicaba ${ }^{49}$ (1866). Ao saber da excursão de um grupo de norteamericanos pela província paulista, juntou-se a eles para analisar o desenvolvimento da lavoura algodoeira nas regiões visitadas. Sua carta apresenta a promissora situação do cultivo deste gênero, assim como as inúmeras potencialidades naturais para a exploração, destacando a necessidade de melhores caminhos para o escoamento da produção e a inserção de São Paulo no comércio mundial.

Os viajantes registraram o que viram e viveram e somaram a tais informações imagens e dados obtidos através de diferentes obras. E implementaram seus relatos com elementos visuais ${ }^{50}$ - daguerrótipos, aquarelas, mapas, etc. e textuais - documentos, pareceres, relatórios, etc. - capazes de proporcionar um quadro mais acessível dos locais visitados e dos temas tratados.

As imagens produzidas são um veículo de informação tanto para os leitores europeus e norte-americanos quanto para os brasileiros, pois lhes ensinou a ver sua própria paisagem e definiu maneiras de descrevê-la ${ }^{51}$. Como sugere Flora Süssekind: “Lembre-se, ainda, que uma das formas de adestramento artesanal de um outro pintor, Almeida Júnior, foi a cópia de desenhos originais do paisagista-viajante Hercules Florence. O que se observa numa tela como A partida da monção, por exemplo, ${ }^{, 52}$.

Em nossa pesquisa abordamos a iconografia produzida pelos viajantes comparativamente às descrições dos locais visitados, e também com outras imagens

\footnotetext{
${ }^{48}$ D. P. Kidder e J. C. Fletcher. O Brasil e os brasileiros..., op. cit., vol. 1, p. XVIII.

${ }^{49}$ Segundo Alice Canabrava "a primeira fábrica de tecidos da Província, que de fato adquiriu estabilidade e subsistiu, foi a fábrica São Luiz, em Itu, a primeira que se estabeleceu no período estudado [1861-1875] [...] Um dos sócios dessa empresa, o barão de Piracicaba (Capitão Antonio Paes de Barros), retirou-se logo depois da sociedade para fundar, em 1871, com seu filho, o major Diogo Antonio de Barros, uma fábrica de tecidos na capital da Província. Começou ela a funcionar em 1874 [...]”. Alice P. Canabrava. O algodão em São Paulo: 1861-1875. 2. ed. São Paulo: Ed. T. A. Queiroz, 1984, p. 282-283.

50 "Do material iconográfico sobre São Paulo e que temos conhecimento até o momento, percebe-se que os artistas tenderam a não registrar tipos ou o movimento humano nas ruas e junto aos edifícios da cidade, o que pode ter sido um dos estímulos para a visão de uma cidade vazia e sem vida social”. Denise Aparecida Soares de Moura. Economia, cultura e sociedade em São Paulo..., op. cit., p. 27.

${ }^{51}$ Flora Süssekind. O Brasil não é longe daqui: o narrador, a viagem. 3. reimp. São Paulo: Companhia das Letras, 2008, p. 39.

${ }^{52}$ Ibidem, p. 40.
} 
produzidas por outros viajantes. Não as analisaremos detidamente, apenas pretendemos traçar um quadro mais amplo dos recursos que utilizaram para registrar e descrever a realidade paulista.

O inglês Edmund Pink em 1823 percorreu São Paulo a fim de visitar os distritos açucareiros, e através do seu itinerário nota-se que teve como foco os do "quadrilátero do açúcar" ${ }^{\prime 53}$. Para Nicolau Sevcenko, o viajante intencionava promover o levantamento de dados sobre essas regiões tanto para sua empresa familiar, a Standfast \& Co. de propriedade de George Thomas Standfast e localizada no Rio de Janeiro, quanto à comunidade inglesa de negociantes, atenta às novas possibilidades de lucro ${ }^{54}$.

Em seu relato Diário de uma viagem através das províncias do Rio de Janeiro e São Paulo. Brasil. América do Sul ${ }^{55}$ temos uma série de aquarelas retratando os caminhos por onde esteve e alguns aspectos da vida paulista ${ }^{56}$. No dia 30 de maio de 1823 chegou à Província de São Paulo via porto de Santos e visitou Cubatão, Jundiaí, Campinas, Mogi Mirim, Itu, Porto - Feliz, Sorocaba e a capital.

Em sua passagem por Itu além de escrever sobre alguns aspectos da lavoura canavieira encontrada, pintou a aquarela Sketch of the city of St. Pauls taken on the rising ground to the right of the Road to Itu (Perfil da cidade de São Paulo tomada da elevação direita do Caminho para Itu, 1823). O caminho de Santos foi retratado em Sketch of the City of St. Pauls taken from near the Spot where the Gallows is erected to the left of the Road from Santos as you enter de city (Perfil da Cidade de São Paulo tomado nas imediações da Forca, à esquerda do Caminho de Santos, na Estrada da Cidade, 1823).

\footnotetext{
53 "No quadrilátero formado por Sorocaba, Piracicaba, Mogi Guaçu e Jundiaí, área de eleição da cana de açúcar em São Paulo na segunda metade do século XVIII e na primeira do século XIX, e que já em 1797 produzia 83435 arrobas de açúcar destinadas à exportação, destacam-se duas áreas: Itu e Campinas. Não nos devemos esquecer, entretanto, que a cana de açúcar estava disseminada por toda a área [paulista] em maior ou menor intensidade". Maria Thereza Schorer Petrone. A lavoura canavieira em São Paulo. Expansão e declínio (1765-1851). São Paulo: Difusão Européia do Livro, 1968, p. 41.

${ }^{54}$ Nicolau Sevcenko. Vislumbrando novas perspectivas. In.: Edmund Pink. A São Paulo de Edmund Pink. Trad. e transcr. Cristina Antunes. São Paulo: CBA, 2000, p. 12.

${ }^{55}$ Seu relato, salvaguardado pela Bolsa de Valores de São Paulo, permaneceu inédito até o ano de 2000, quando foi publicado pela CBA. Edmund Pink. A São Paulo de Edmund Pink..., op. cit.. Nesta obra temos o diário do viajante intitulado Diário de uma viagem através das províncias do Rio de Janeiro e São Paulo. Brasil. América do Sul, e uma série de aquarelas produzidas por ele.

${ }^{56}$ As aquarelas pintadas por Edmund Pink foram reproduzidas na obra de Pedro Corrêa do Lago. Iconografia Paulistana: do século XIX. 2. ed. rev. e ampl. São Paulo: Capivara, 2003, p. 60-69.
} 


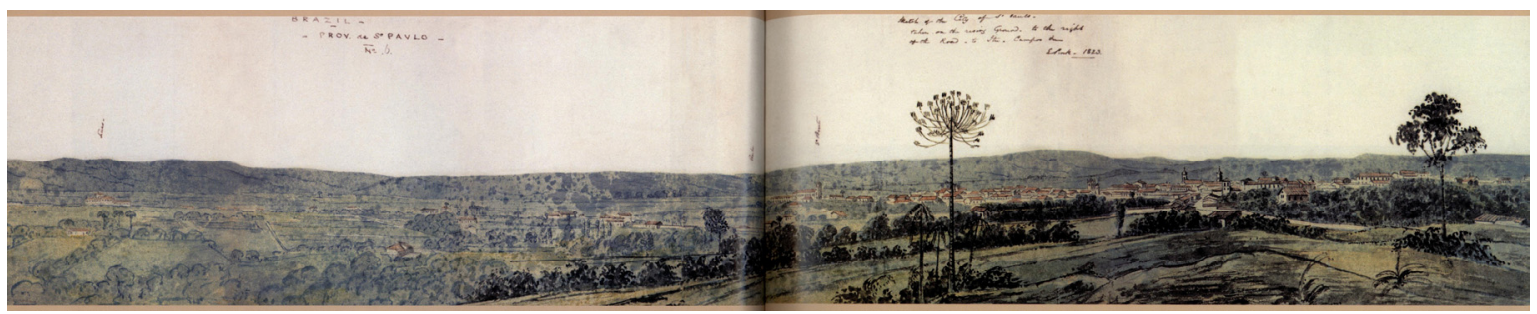

Figura 1. Edmund Pink. "Sketch of the city of St. Pauls taken on the rising ground to the right of the Road to Itu (Perfil da Cidade de São Paulo tomada da elevação à direita do Caminho para Itu)", 1823. Aquarela, 17 x 98,5 cm. Acervo de Artes da BOVESPA, São Paulo, Brasil. In.: Pedro Corrêa do Lago. Iconografia Paulistana: do século XIX. 2. ed. rev. e ampl. São Paulo: Capivara, 2003, p. 64-65.

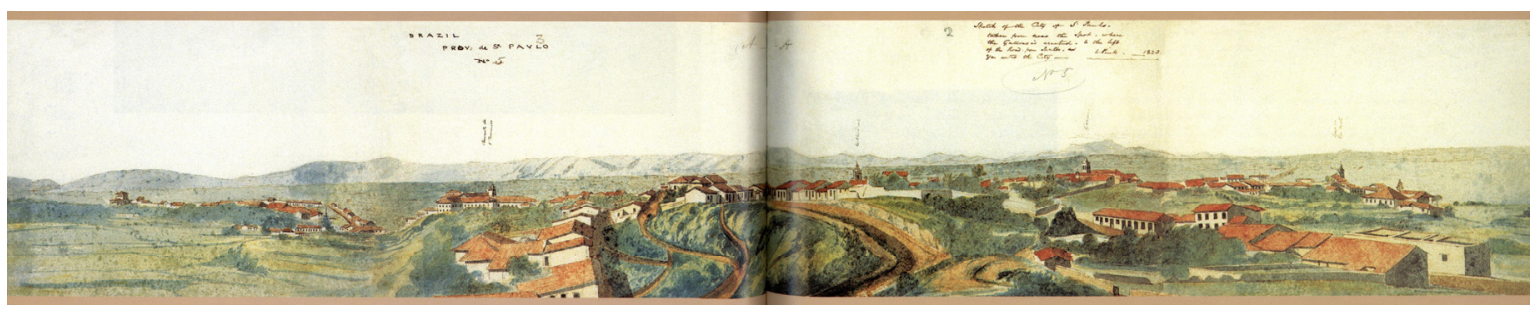

Figura 2. Edmund Pink. "Sketch of the City of St. Pauls taken from near the Spot where the Gallows is erected to the left of the Road from Santos as you enter de city (Perfil da Cidade de São Paulo tomado nas imediações da Forca, à esquerda do Caminho de Santos, na Estrada da Cidade)", 1823. Aquarela, 16, $5 \mathrm{~cm} \mathrm{x}$ $90 \mathrm{~cm}$. Acervo de Artes da BOVESPA, São Paulo, Brasil. In.: Pedro Corrêa do Lago. Iconografia Paulistana: do século XIX. 2. ed. rev. e ampl. São Paulo: Capivara, 2003, p. 64-65. 
Em junho do mesmo ano percorreu o Ipiranga, onde havia sido proclamada a Independência do Brasil, em 1822, e escreve:

"Cerca de 1 légua antes de se atingir a cidade, passa-se pelo lugar chamado Piranga [sic], uma casa desolada - a Venda - onde o imperador, então apenas regente, encontrou o mensageiro com os despachos vindos do Rio (o imperador havia estado em Santos de onde estava retornando) que aparentemente não foram recebidos por ele com prazer. E, sem expressar suas idéias para ninguém ao seu redor, arrancou a roseta constitucional portuguesa azul e branca de seu chapéu, pisou nela e proclamou a Independência do Brasil, passando a usar a roseta verde e amarela" ${ }^{\$ 7}$.

A região abordada em sua obra foi registrada na aquarela Sketch of Peranza, the spot where the present Emperor Dom Pedro or Then Prince Regent Declaredt the Independece of Brazil (Vista de Peranza [sic], lugar onde o atual Imperador Dom Pedro ou o Então Príncipe Regente declarou a Independência do Brasil, 1823). Segundo Pedro Corrêa do Lago esta aquarela "é o único testemunho quase contemporâneo do local onde foi proclamada a independência, retomada na cena pintada por Pedro Américo 65 anos depois e por Miguel Dutra em sua aquarela datada de $1847^{, 58}$.

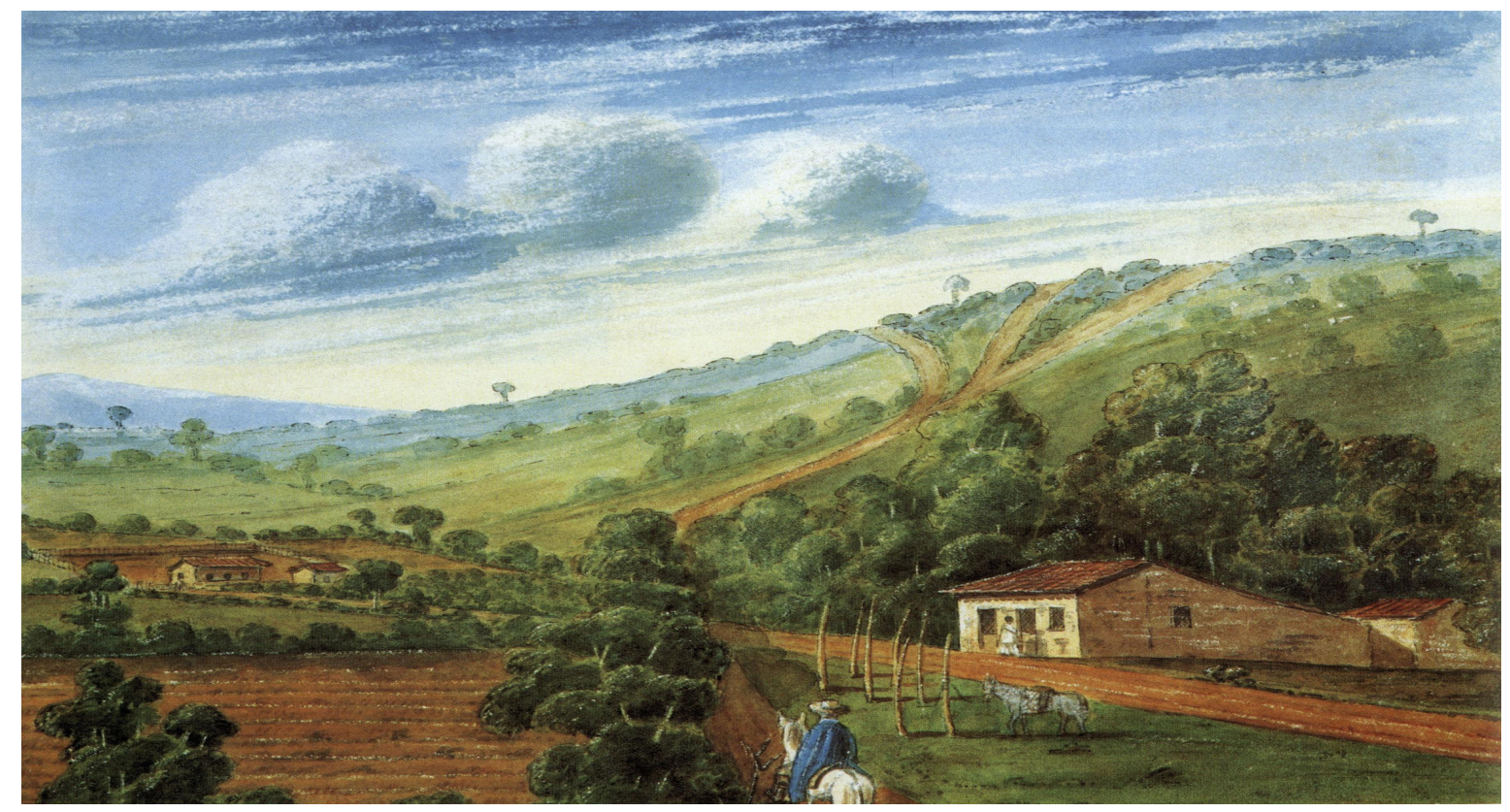

Figura 3. Edmund Pink. "Sketch of Peranza, the spot where the present Emperor Dom Pedro or Then Prince Regent Declaredt the Independece of Brazil (Vista de Peranza [sic], lugar onde o atual Imperador Dom Pedro ou o então Príncipe Regente declarou a Independência do Brasil)”, 1823. Aquarela, 18,5 x 24 cm. Acervo de Artes da BOVESPA, São Paulo, Brasil. In.: Pedro Corrêa do Lago. Iconografia Paulistana: do século XIX. 2. ed. rev. e ampl. São Paulo: Capivara, 2003, p. 68.

\footnotetext{
${ }^{57}$ Edmund Pink. A São Paulo de Edmund Pink..., op. cit., p. 85.

${ }^{58}$ Pedro Corrêa do Lago. Iconografia Paulistana..., op. cit., p. 68.
} 
Após percorrer o quadrilátero do açúcar, em 21 de outubro de 1823 deixou São Paulo com destino ao Rio de Janeiro. O caminho é retratado em duas aquarelas: View of Saint Pauls from the Rio Road (Panorama de São Paulo no caminho para o Rio de Janeiro, 1823) e Sketch of St. Pauls taken from the Rio Road (Esboço da Cidade de São Paulo visto do Caminho para o Rio, 1823).

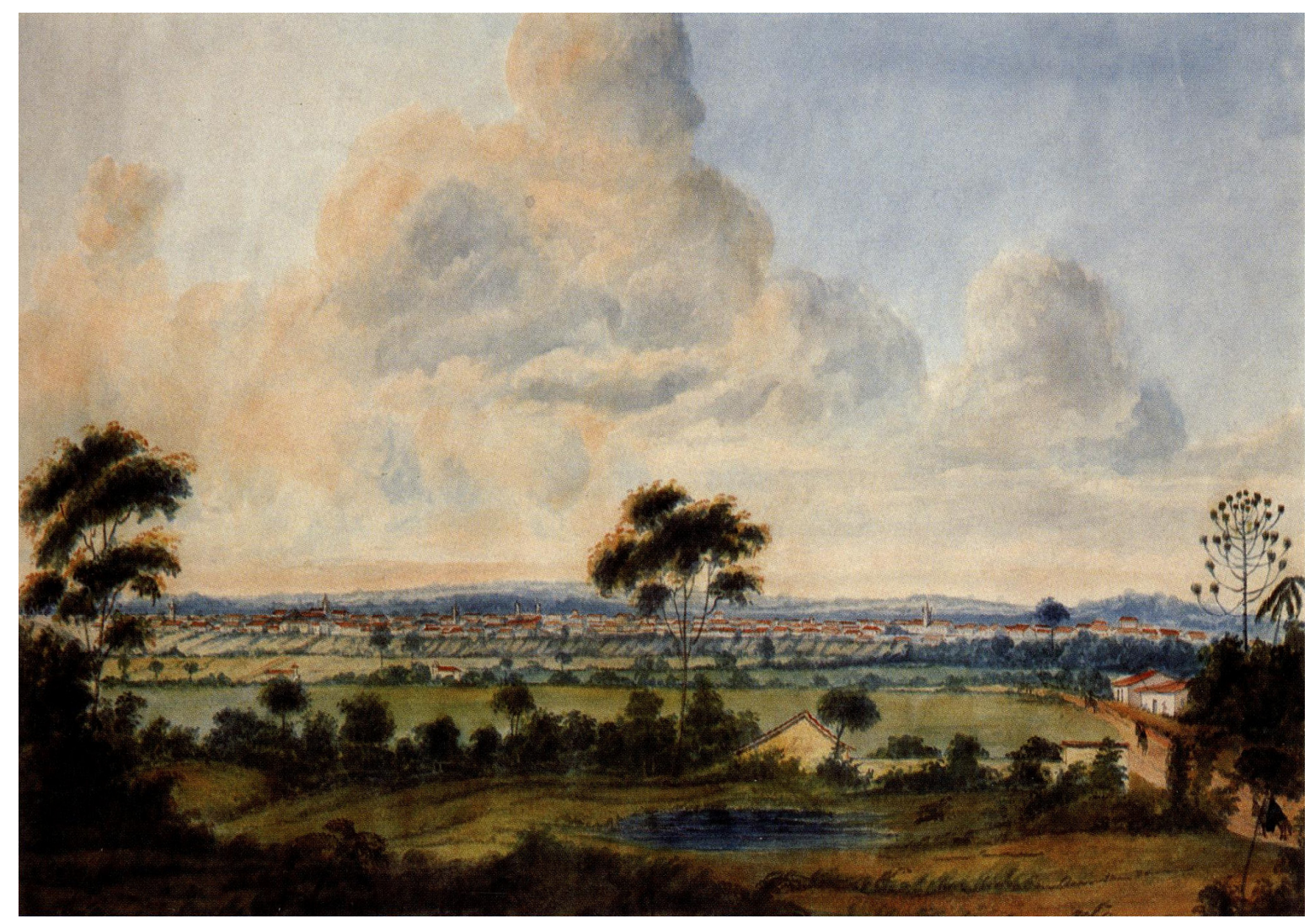

Figura 4. Edmund Pink. "View of Saint Pauls from the Rio Road (Panorama de São Paulo do Caminho para o Rio de Janeiro)", 1823. Aquarela, 25 x $44 \mathrm{~cm}$. Acervo de Artes da BOVESPA, São Paulo, Brasil. In.: Pedro Corrêa do Lago. Iconografia Paulistana: do século XIX. 2. ed. rev. e ampl. São Paulo: Capivara, 2003, p. 63.

O norte-americano James Fletcher adicionou às informações apontadas em sua obra uma série de ilustrações. Segundo o viajante "são ou desenhos ou vistas daguerreotípicas do natural. [E] foram fiel e cuidadosamente executadas pelos Srs. Van Ingen $\mathcal{E}$ Snyder, de Filadélfia" ${ }^{, 59}$.

Durante sua visita à São Paulo, de Santos seguiu por Cubatão para a cidade de São Paulo, e depois para Campinas, Limeira, Ibicaba (na fazenda do Senador Vergueiro) e

\footnotetext{
${ }^{59}$ D. P. Kidder e J. C. Fletcher. O Brasil e os brasileiros..., op. cit., vol. 1, p. XIII.
} 
retornou ao porto santista "para tomar o vapor do dia 6 [de julho de 1855] para o Rio"60. Em seu relato, ao apresentar as dificuldades e melhorias feitas na passagem de Cubatão compara-as à descrição do seu conterrâneo Daniel Kidder, escrita em 1839:

"A descrição acima [de Kidder] da estrada era rigorosamente verdadeira, há quinze anos passados; mas presentemente, graças a uma previdente engenharia, as subidas não são tão íngremes, e com grandes despesas toda a estrada foi macadamizada. Mas mesmo assim, a subida é demasiadamente forte para veículos pesadamente carregados. Isso será em breve remediado" $" 61$.

Sua experiência no local é comparada tanto com a passagem de Kidder como a do jesuíta Simão Vasconcelos, retirada da Crônica da Companhia de Jesus no Estado do Brasil de 1663, excerto que já havia sido reproduzido por Kidder no seu relato de $1845^{62}$ :

"Quando subi a serra montado num cavalo de aspecto tão desanimado, o nevoeiro cobria tudo, apenas podendo eu ver uma vara diante de mim; mas, na volta, não só as montanhas estavam banhadas pela luz em cheio do sol, como as planícies em baixo e o oceano distante, pareciam ter sido aproximados, como por um efeito de mágica. Havia uma primitividade e uma sublimidade tais na paisagem que não as vira excedidas nem mesmo nos arredores do Rio de Janeiro. Do cume da montanha os escuros e ásperos desfiladeiros, não estavam ainda revestidos da abundante vegetação que se encontrava em outros lugares. As torrentes jorravam de alguns dos mais altos cumes e estrondavam em baixo nas grotas fundas.

O jesuíta Vasconcelos fez a subida desta Serra há duzentos anos passados, e sua descrição do cenário é esboçada com mão de mestre; mas a sua avaliação da altitude foi certamente exagerada", ${ }^{\text {"3 }}$.

Após apresentar a crítica de Daniel Kidder aos registros de Vasconcelos, sobre a altitude da Serra considera:

"Todavia, parece-me que a altitude avaliada da Serra, feita pelo bom frei Vasconcelos, foi justa, admitindo-se o seu padrão de medida; pois, mesmo considerando que ele não tivesse asma, subir uma montanha escarpada [...], não viajando, porém, subindo com pés e mãos [...], e isto entre penhascos e precipícios, sem dúvida alguma seria suficiente para fazer qualquer um palpitar $[\ldots]^{\prime \prime 64}$.

A discussão sobre o caminho pela Serra de Cubatão conta com a imagem deste local, porque possibilita a visualização da experiência retratada por Fletcher. Segundo ele "na gravura, a atual estrada real, relativamente ainda muito sinuosa, mostra o seu forte

${ }^{60}$ D. P. Kidder e J. C. Fletcher. O Brasil e os brasileiros..., op. cit., vol. 2, p. 139.

${ }^{61}$ Ibidem, p. 61.

${ }^{62}$ Daniel Parish Kidder. Reminiscências de viagens..., op. cit., p. 193.

${ }^{63}$ D. P. Kidder e J. C. Fletcher. O Brasil e os brasileiros..., op. cit., vol. 2, p. 62-63.

${ }^{64}$ Ibidem, p. 64. [Itálico do autor]. 
contraste com a estrada quase vertical feita pelos primeiros Jesuitas, antes daquela que o Dr. Kidder nos descreve. A estrada dos Jesuitas é a linha escura que parece dividir a montanha cônica em partes iguais ${ }^{\prime 65}$.

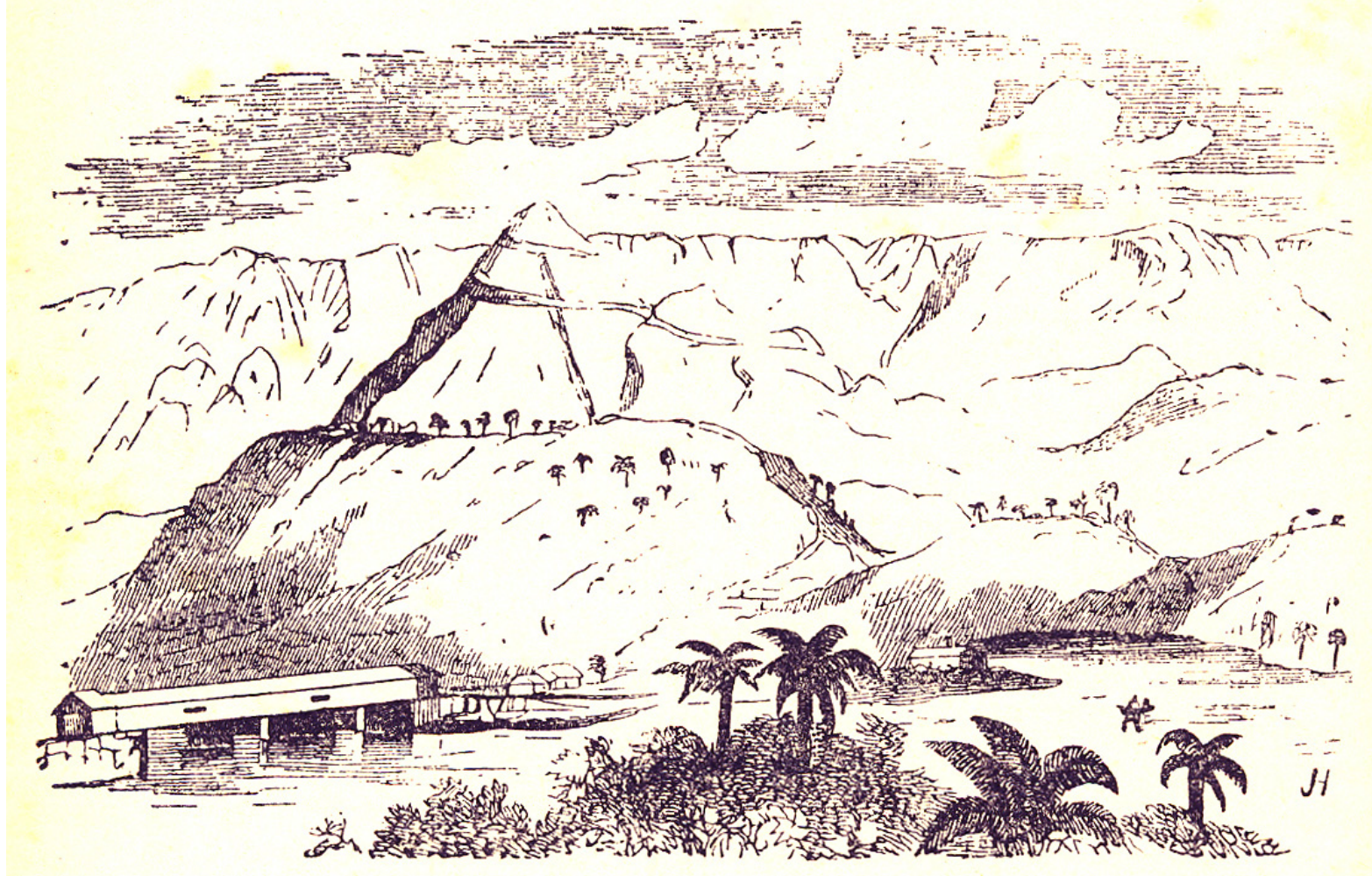

Figura 5. D. P. Kidder e J. C. Fletcher. "Ponte e Serra de Cubatão", 1857. Litografia, 5 x 9 cm. Ilustração do relato O Brasil e os brasileiros (Esboço histórico e descritivo). São Paulo: Companhia Editora Nacional, 1941, vol. 2, p. 62. Sobre a autora do desenho diz na página 135: "Em Limeira encontrei um engenheiro alemão, que, com sua esposa hamburguesa, uma senhora bastante distinta, (a quem sou devedor dos esboços da ponte de Cubatão e da casa de colono alemão) formam uma agradável companhia para o Dr...”.

Outras imagens são apresentadas em seu relato, e nelas encontramos retratos de indígenas, paisagens, construções, locais visitados e situações vividas pelo viajante e por ele consideradas inusitadas, como as esporas erroneamente colocadas por seu guia, o velho Congo, que tanto provocou risos nos paulistas no caminho da cidade de São Paulo para Limeira ${ }^{66}$.

${ }^{65}$ D. P. Kidder e J. C. Fletcher. O Brasil e os brasileiros..., op. cit., vol. 2, p. 62.

66 "Meu guia era um preto velho de sessenta anos, cujas vestimentas consistiam numa jaqueta usada, um par de calças e um velho chapéu de palha. Seus calcanhares nus e ossudos não ostentavam o mais leve sinal de espora. Como eu tinha de viajar depressa, para fazer a minha viagem em um dado tempo, vi que não podia conservar o velho Congo assim desarmado nas extremidades dos pés; e, dirigindo o cavalo para uma loja de ferragens, dei ao velho um par de esporas de ferro, cujas pontas eram do tamanho do esporão de um galo de briga. Com um pedaço de corda ele amarrou-as em seus tornozelos descarnados e, montando, pusemo-nos 

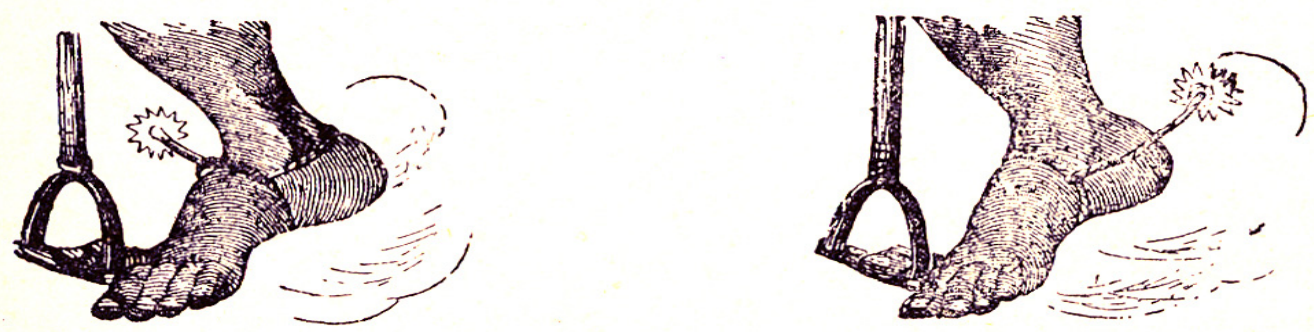

Figura 6. D. P. Kidder e J. C. Fletcher. "Esporas erroneamente colocadas pelo velho Congo", 1857. Litografia, 2,5 x 8,5 cm. Ilustração do relato O Brasil e os brasileiros (Esboço histórico e descritivo). São Paulo: Companhia Editora Nacional, 1941, vol. 2, p. 103.

John Mawe também se vale do recurso iconográfico em duas edições do seu relato Viagens ao interior do Brasil. A primeira, publicada em Londres no ano de 1812, e reproduzida nas edições seguintes, tem "a primeira imagem da cidade [de São Paulo] no século XIX de que se tem notícia: A view of the gold washing at Jaragua near Saint Pauls (Uma Vista da Lavagem do Ouro em Jaraguá Perto de São Paulo) [1812], gravura executada por Barrenger, a partir de um esboço do próprio Mawe"67.

logo em caminho e em minutos, estávamos saindo da cidade de São Paulo. [...] Ouvindo um barulho de cascos atrás de nós, voltei-me e vi dois paulistas galopando na nossa mesma direção. Passando à nossa frente, caíram num acesso de risos imoderado. Não pude a princípio adivinhar o que excitava tanto as suas capacidades cômicas, até que um deles exclamou, 'Olha as esporas'. Olhando para baixo, percebi que a corda, que amarrava as pontas de ferro aos calcanhares do velho Congo, descrevera uma volta e a espora se colocara mesmo por cima do seu peito do pé”. D. P. Kidder e J. C. Fletcher. O Brasil e os brasileiros..., op. cit., vol. 2, p. 102-103. [Itálicos do autor].

${ }^{67}$ Pedro Corrêa do Lago. Iconografia Paulistana..., op. cit., p. 18. 


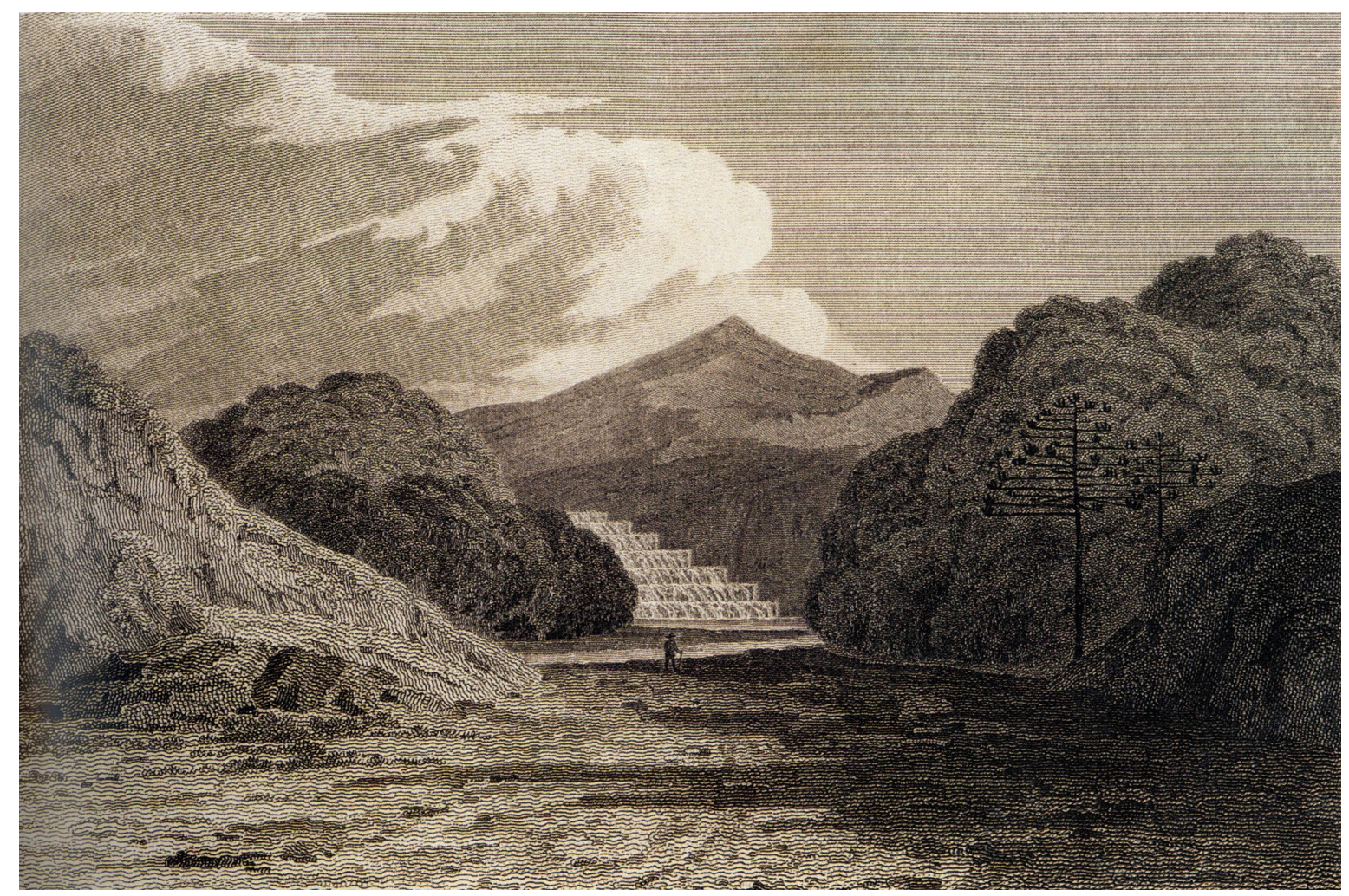

Figura 7. John Mawe. "A view of the gold washing at Jaragua near Saint Pauls (Uma vista da lavagem do ouro em Jaraguá, perto de São Paulo)”, 1812. Gravura em cobre, 15,2 x 20,8 cm. Lowry (del., a partir de esboço do próprio John Mawe) e Barrenger (sculpt.). Coleção Ruy Souza e Silva, São Paulo, Brasil. Esta imagem foi publicada na primeira edição do relato Travels in the Interior of Brazil..., Londres: Longman, Hurst, Rees, Orme \& Brown, 1812, p. 78. In.: Pedro Corrêa do Lago. Iconografia Paulistana: do século XIX. 2. ed. rev. e ampl. São Paulo: Capivara, 2003, p. 19.

A segunda gravura é apresentada pela primeira vez na edição italiana de 1817, e é intitulada Costume delle Pauliste (Traje das paulistas) [1817]. De acordo com Pedro Corrêa do Lago esta imagem não indica ter sido feita a partir de desenhos de Mawe, porque "apesar de ser em grande parte conforme às outras imagens de vestimentas das mulheres de São Paulo na época quanto ao comprimento do vestido, tanto os detalhes da gola, de inspiração holandesa, quanto o chapéu florido aparecem um pouco fantasiosos (o formato do chapéu e mais semelhante àquele usado pelos homens). Na verdade, o vestido aparenta ter sido interpretado pelo artista italiano [Giuseppe Dall'Acqua] que assina a gravura, a partir da descrição do próprio Mawe em seu livro: '...a vestimenta das mulheres fora da casa, especialmente quando vão à igreja, consiste de uma roupa de seda preta, com um longo xale da mesma fazenda e guarnecido com renda larga'. Como se pode observar nos desenhos de Aimé Taunay e Landseer, a renda guarnecida o xale e não 
a gola do vestido, como parece ter entendido o artista italiano "68. Abaixo reproduzimos as imagens elaboradas pelos três viajantes estrangeiros sobre o vestuário da mulher paulista.

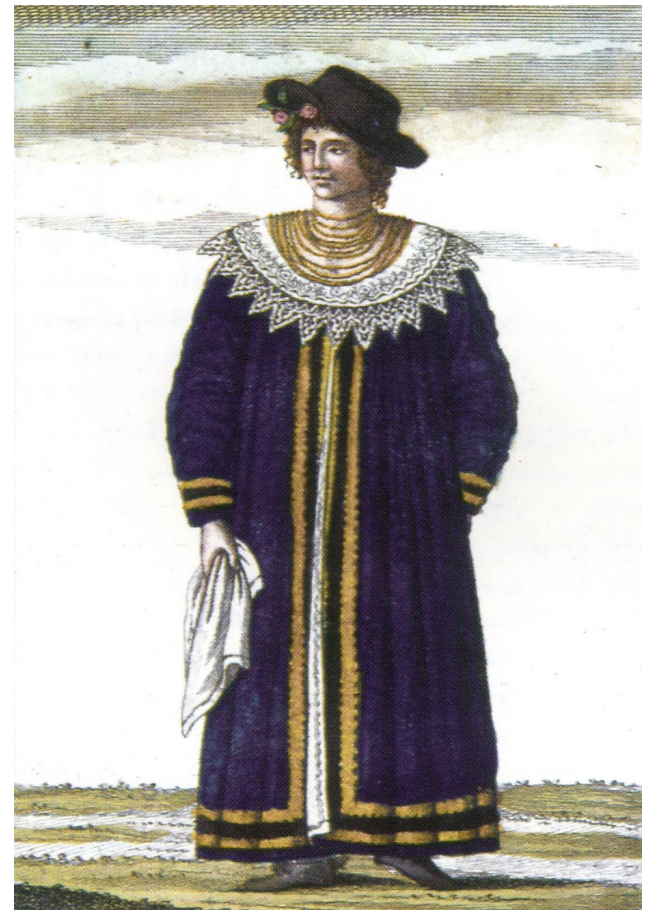

Figura 8. John Mawe. "Costume delle Pauliste (Traje das paulistas)", 1817. Gravura em cobre colorida a mão, 17 x $10 \mathrm{~cm}$. Dall'Acqua (inc.) e Lazarretti (col.). Coleção Ruy Souza e Silva, São Paulo, Brasil. Esta imagem foi publicada na edição italiana do relato Viaggio nell'interno del Brasile. Milão: Tipografia, Sonzogno e Comp., 1817, p. 138. In.: Pedro Corrêa do Lago. Iconografia Paulistana: do século XIX. 2. ed. rev. e ampl. São Paulo: Capivara, 2003, p. 18 .

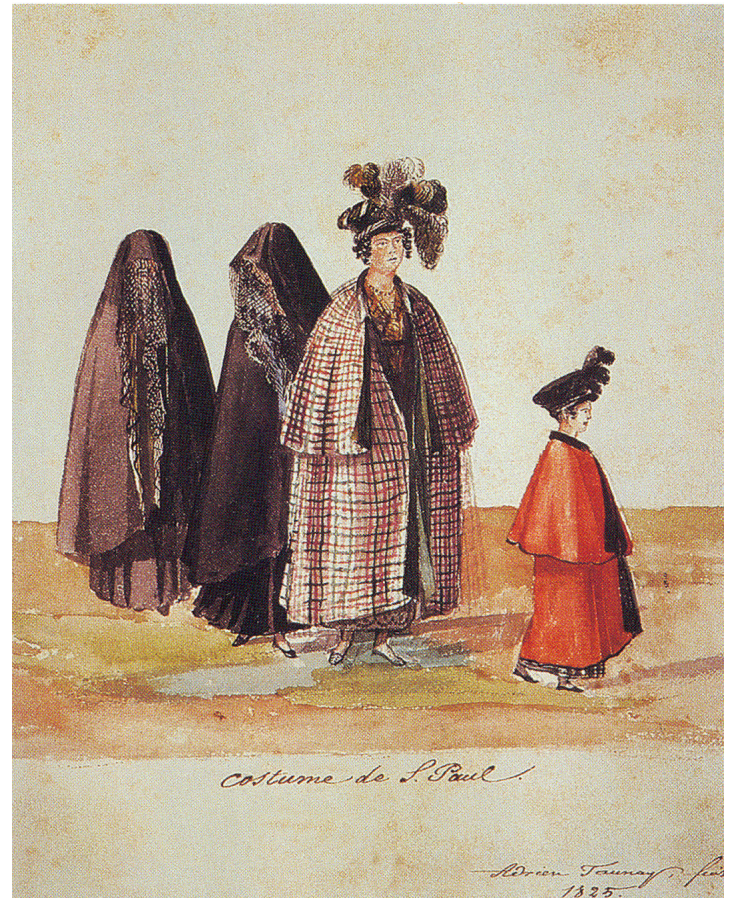

Figura 9. Aimé-Adrien Taunay. "Costume de S. Paul, 1825". Aquarela e tinta sobre papel, 21,5 x $17,5 \mathrm{~cm}$. Academia de Ciências da Rússia, São Petesburgo, Rússia. In.: Pedro Corrêa do Lago. Iconografia Paulistana: do século XIX. 2. ed. rev. e ampl. São Paulo: Capivara, 2003, p. 75.

\footnotetext{
${ }^{68}$ Pedro Corrêa do Lago. Iconografia Paulistana..., op. cit., p. 18.
} 


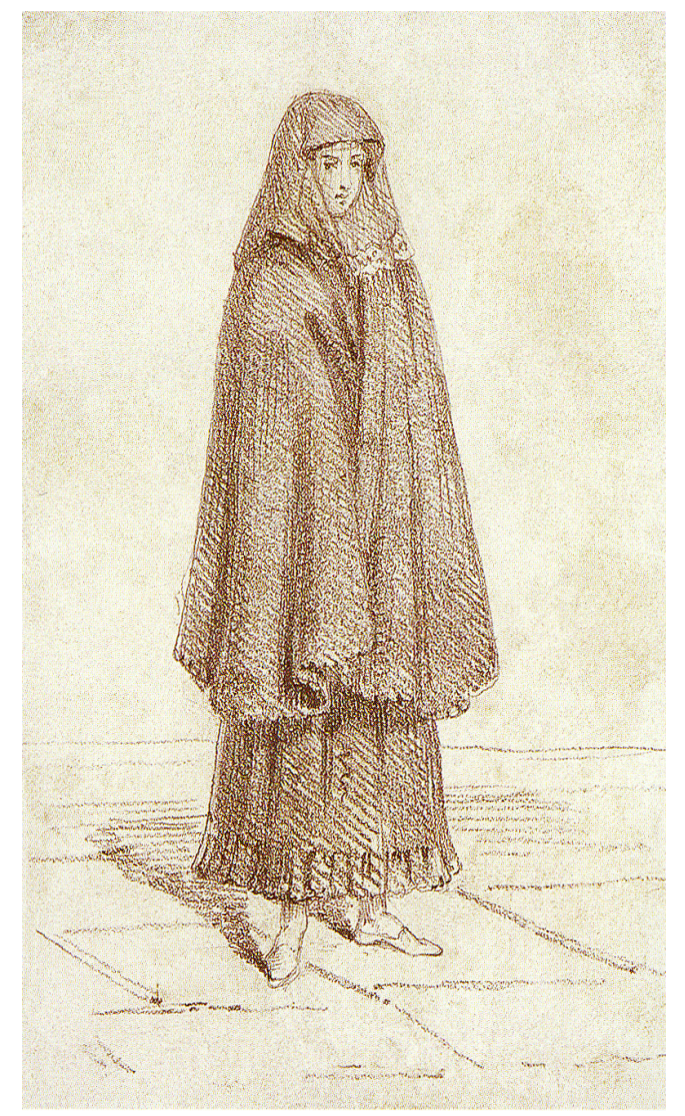

Figura 10. Charles Landseer. "Lady of St. Pauls", 1827. Lápis, 16 x 11, $5 \mathrm{~cm}$. Coleção IMS, Rio de Janeiro, Brasil. In.: Pedro Corrêa do Lago. Iconografia Paulistana: do século XIX. 2. ed. rev. e ampl. São Paulo: Capivara, 2003, p. 98.

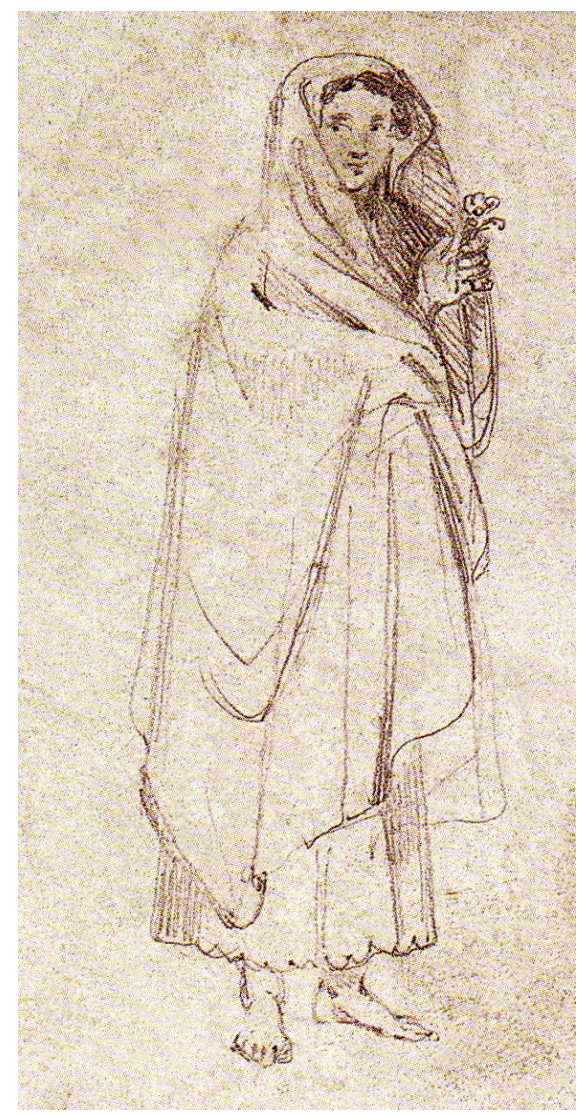

Figura 11. Charles Landseer" . "Woman of St. Pauls", 1827. Lápis, 11 x 5, 5, cm. Coleção IMS, Rio de Janeiro, Brasil. In.: Pedro Corrêa do Lago. Iconografia Paulistana: do século XIX. 2. ed. rev. e ampl. São Paulo: Capivara, 2003, p. 105.

Destacamos este caso especificamente para lembrar a questão das mediações entre o autor e o artista que realiza a obra gráfica. As imagens produzidas pelos próprios viajantes já contém em si mediações pelo olhar, conhecimento artístico, modelos dominantes e conhecimento/compreensão do objeto. E as produzidas a partir de descrições sofrem duplamente de tais condições.

Mawe ao percorrer e estudar a ocorrência mineralógica em Minas Gerais e na região paulista das minas do Jaraguá apresenta o maquinário utilizado na busca de minérios e uma série de gravuras sobre os cristais de diamantes, topázio e turmalina,

\footnotetext{
${ }^{69}$ A coletânea com alguns dos desenhos realizados por Charles Landserr pode ser encontrada na obra Charles Landseer. Landseer. Editor Cândido Guinle de Paula Machado. Textos Alberto Rangel. São Paulo: Lanzara S. A., 1972.
} 
seguida da explicação de cada imagem. Quando retornou para Inglaterra, no ano de 1811, seus conhecimentos sobre mineralogia adquiridos nas minas da Inglaterra e da Escócia, somados à experiência de campo no Brasil foram utilizados na loja que abriu na Strand (margem do Tamisa) perto de Summerset House, tendo adquirido renome como perito conhecedor de minerais e pedras preciosas ${ }^{70}$. O viajante também escreveu obras sobre mineralogia, geologia e pedras preciosas.

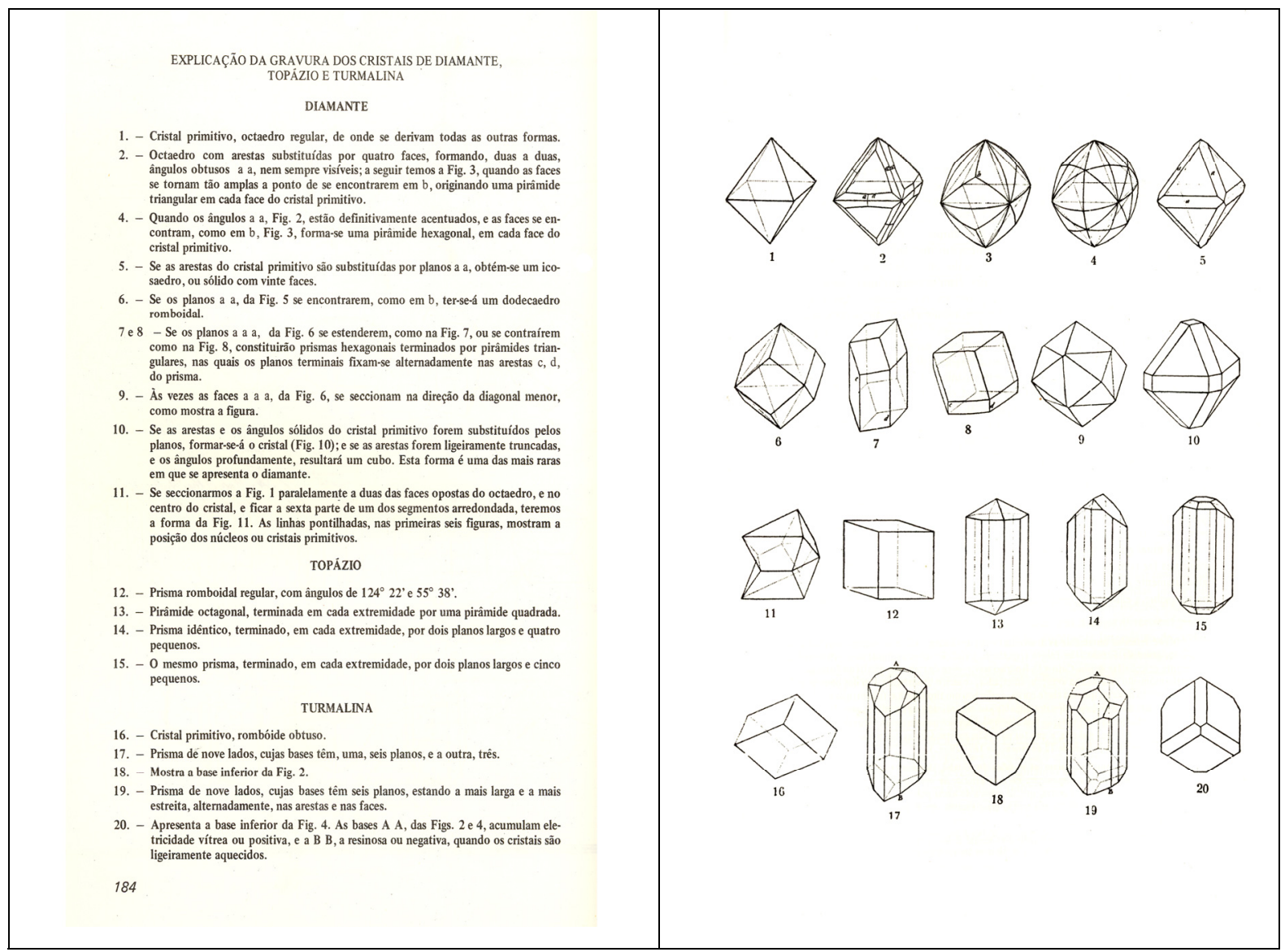

Figura 12. John Mawe. "Explicação da gravura dos cristais de diamante, topázios e turmalina". Gravura, 15 x 17, 8 cm. In.: John Mawe. Viagens ao interior do Brasil. Belo Horizonte: Ed. Itatiaia; São Paulo: Edusp, 1978, p. 184-185.

No seu relato somou às descrições dos locais visitados e às gravuras sua rota de viagem apresentada no mapa “A Map of the Author's Route from Rio de Janeiro to Canta Gallo. Also to Villa Rica and thro'the Centre of the Gold Mines to Tejuco, the Capital of

\footnotetext{
${ }^{70}$ Bernardo Barham Woodward. Dictionary of National Biography, t. XIII, p. 110-111. apud. Clado Ribeiro de Lessa. Introdução. In.: John Mawe. Viagens ao interior do Brasil..., op. cit., p. 16.
} 
the Diamond, Mines \& District called Cerro do Frio". Todavia, no itinerário traçado as regiões paulistas visitadas não estão inclusas.

\section{MAPA 1 - A Map of the Author's Route from Rio de Janeiro to Canta Gallo also to Villa Rica and thro the Centre of the Gold Mines to Tejuco, the Capital of the Diamond Mines \& District called Cerro do Frio. John Mawe.}

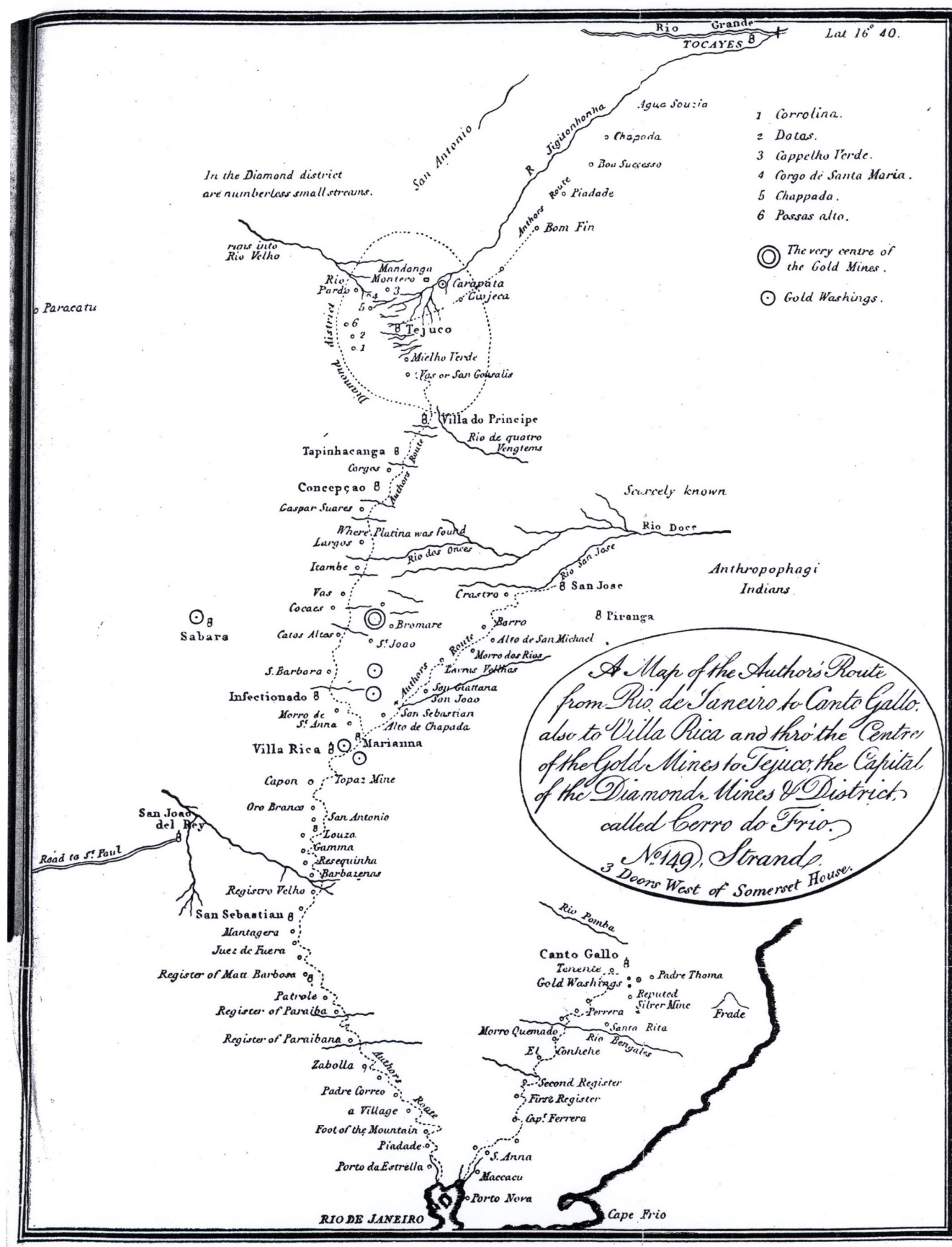

Itinerário do autor.

(mapa da $1 .^{\mathrm{a}}$ ed. inglesa)

FONTE: John Mawe. "Itinerário do autor". Este mapa foi publicado na primeira edição do relato Travels in the Interior of Brazil..., Londres: Longman, Hurst, Rees, Orme \& Brown, 1812. In.: John Mawe. Viagens ao interior do Brasil. Belo Horizonte: Ed. Itatiaia; São Paulo: Edusp, 1978, p. 183. 
Os viajantes, além do recurso iconográfico, se valeram de outras obras para escrever seus relatos, associando às imagens e à descrição dos locais visitados dados oriundos de relatórios oficiais, trabalhos sobre a história e a geografia brasileira e paulista, jornais, memórias, crônicas, discursos, documentos públicos, relatos de outros viajantes e informações coletadas em arquivos internacionais.

O próprio John Mawe com a notícia da instalação da Família Real no Rio de Janeiro, em 1808, e a decisão de ir para a capital carioca faz um balanço dos dias em que esteve nas terras paulistas, e compara as experiências vividas com as informações que obteve através de alguns trabalhos sobre a região visitada:

"Lembro-me sempre, com a mais grata das emoções, das atenções que recebi nesta cidade, e melhor compreenderão os que não ignoram o que seja visitar uma cidade longínqua, num país estrangeiro, onde, segundo as narrativas dos viajantes anteriores, reina o barbarismo e a falta de hospitalidade, e onde se viram desagradavelmente decepcionados. É fácil de imaginar que encontrei dificuldades em conciliar o caráter dos paulistas, tal como o observei, com as estranhas referências à sua origem espúria, citada pelos geógrafos modernos. Estas referências, baseadas no testemunho suspeito dos jesuítas do Paraguai e, com variantes, no dos melhores historiadores portugueses, foram ultimamente refutadas, da maneira mais completa, por um brilhante membro da Real Academia de Ciências de Lisboa [Frei Gaspar da madre de Deus]. Ele expôs plenamente a inconsistência das afirmativas de Vaissette e Charlevoix, ao atribuírem a origem de São Paulo a um bando de refugiados, composto de espanhóis, portugueses, mestiços, mulatos e outros, que fugiram para aqui de várias partes do Brasil, e estabeleceram uma república de piratas. Demonstra de maneira satisfatória terem sido os primeiros colonizadores os índios de Piratininga e os jesuítas, e que a cidade, desde sua fundação, não reconheceu nenhuma outra soberania, senão a de Portugal. A verdade desta afirmação é mais tarde confirmada pelo caráter predominante dos paulistas, que, longe de herdarem a infâmia, vínculo natural de descendentes de velhacos e vagabundos, se tornaram conhecidos, em todo o Brasil, pela sua probidade, indústria e afabilidade de maneiras" $" 71$.

O relato de Mawe foi utilizado por outros viajantes que compararam suas informações com os dados registrados pelo inglês. Em janeiro de 1839, trinta anos após sua viagem, desembarcou nas terras paulistas o pastor metodista norte-americano Daniel Parish Kidder, e tal como ele seguiu de Santos para a cidade de São Paulo via Serra de Cubatão. Sobre sua passagem pelo local compara-a com a experiência de Mawe e os valores apresentados na medição do Cap. King, e concluí serem errôneos os dados do britânico sobre a latitude e visibilidade na região. Conforme aponta:

\footnotetext{
${ }^{71}$ John Mawe. Viagens ao interior do Brasil..., op. cit., p. 74.
} 
"A altura da Serra não é tão grande quanto se tem repetidamente afirmado. $\mathrm{O}$ sr. Mawe dá 6.000 pés como sendo a mais baixa estimada. Todavia o Cap. King, medindo-a de fato, determinou sua altitude em apenas 2, 250 pés. O Sr. Mawe cometeu erro ainda maior afirmando que do topo da serra não se avista Santos. Não sabemos como explicar tal deslize, a menos que se suponha que a cidade e suas adjacências estivessem encobertas pela neblina conquanto o topo da serra estivesse limpo na ocasião em que aquele cavalheiro observou. De fato esse fenômeno ocorre às vezes, sendo muito mais freqüente no inverno"72a-b .

Kidder na elaboração de Reminiscências de viagens e permanências nas províncias do sul do Brasil (1845) utiliza, além do relato de Mawe, outros trabalhos e fontes. Segundo o viajante:

"Consultamos freqüentemente a história de Southey e sua continuação pelo sr. Armitage. Sentimo-nos profundamente gratos pelas notas e jornais fornecidos por nosso estimado colega, Rev. Justin Spaulding que morou durante perto de seis anos no Rio de Janeiro. O mesmo diremos com relação às diversas memórias e aos vários discursos apresentados ao Instituto Histórico e Geográfico, recentemente fundado na capital brasileira. Fizemos, além disso, numerosas referências a relatórios de presidentes de Províncias, documentos oficiais, autores brasileiros, em suma, a todas as mais recentes e autênticas fontes de referência do que nos pudemos valer com relação a todos os recantos do Império. [...] Nem podemos regatear expressões de agradecimento para com o falecido $\mathrm{Sr}$. Upshur que nos facilitou o manuseio de valiosos documentos relativos ao Brasil, existentes nos arquivos nacionais de Washington",73.

O atraso na publicação de sua obra não foi considerado um fato problemático, pois neste período fez atualizações nas leituras e acessou novas fontes. Para Kidder "nesse ínterim, consultamos documentos recentes, e, também por meio de correspondência, conseguimos obter informes relativos a um período de quase sete anos, pondo assim o nosso trabalho em dia, na data de sua publicação" ${ }^{74}$ que ocorreu no ano de 1845 . Seu regresso aos Estados Unidos havia se dado em 1840.

Em O Brasil e os brasileiros (1857) Daniel Kidder e James Cooley Fletcher continuaram a agregar aos seus registros uma bibliografia capaz de abarcar as temáticas abordadas:

\footnotetext{
${ }^{72}$ A - Daniel Parish Kidder. Reminiscências de viagens..., op.cit., p. 189-190.

B - Daniel Kidder baseia sua observação no seguinte trecho do relato de Mawe sobre a passagem pela Serra de Cubatão: "Em três horas alcançamos o cume, um vasto planalto, cuja mínima é calculada em seis mil pés. A superfície compõe-se, principalmente, de quartzo, coberto de areia. O mar, embora distante vinte milhas, deu-nos a impressão de banhar as fraldas das montanhas; a parte plana da costa e o Porto de Santos, abaixo de nós, não incidiam no ângulo de visão". John Mawe. Viagens ao interior do Brasil.., op. cit., p. 61. Kidder utilizou a edição inglesa do relato de 1816.

${ }_{73}^{73}$ Daniel Parish Kidder. Reminiscências de viagens..., op. cit., p. 17-18.

${ }^{74}$ Ibidem, p. 18.
} 
"Os autores consultaram todas as obras importantes em francês, alemão, inglês e português, que lhes pudesse [sic] trazer esclarecimentos sobre a história do Brasil, assim como várias memórias publicadas e discursos lidos perante a florescente 'Sociedade Geográfica e Histórica' do Rio de Janeiro. Para os dados estatísticos examinaram pessoalmente os arquivos do Império e das províncias, ou fizeram citações diretas de publicações oficiais" $"$.

As novas edições do relato foram sistemática e continuadamente atualizadas com informações sobre as mudanças ocorridas no cenário brasileiro. $\mathrm{Na} 6^{\mathrm{a}}$ edição, de 1866 , apresentam esta preocupação:

"Para tratar pormenorizadamente das transformações e progressos que o Brasil realizou nos últimos dez anos, seria necessário o espaço de um volume. Assim, foram acrescentadas, em emendas e aditamentos, em notas e apêndices, cerca de cem páginas de matéria nova à presente edição, tendo-se também, em muitos casos, alterado e acrescido o texto. Tanto quanto possível, foi toda a matéria posta em dia (1866), por meio de notas colocadas no final dos capítulos. Em alguns casos, cartas e descrições de viagens foram conservadas, sem mencionar datas, pelo fato de se referirem a hábitos e costumes que não sofreram alterações. Quando o assunto exigia maior espaço, preferiu-se tratá-lo em Apêndice" ${ }^{, 76}$.

Os relatos de viagem abordados neste trabalho são os resultados das incursões destes viajantes ingleses e norte-americanos pela Capitania e depois Província de São Paulo. Concomitantemente às descrições do que viveram, agregaram materiais iconográficos e uma série de dados pesquisados em diferentes trabalhos, o que proporciona ao leitor um aprofundamento das situações e locais apresentados nas obras.

Apesar do intervalo de tempo entre a vinda destes viajantes, eles têm em comum o anseio de mostrarem as potencialidades de enriquecimento, a grande ocorrência de matéria-prima e a possibilidade de sua utilização, o progresso e as transformações da região, vista como um palco para as realizações materiais dos homens, uma reserva de matérias-primas e local para o estabelecimento de atividades produtivas ${ }^{77}$.

\footnotetext{
${ }_{75}^{75}$ D. P. Kidder e J. C. Fletcher. O Brasil e os brasileiros..., op. cit., vol. 1, p. XIII

${ }^{76}$ Ibidem, p. XVIII-XIX.

77 "No século XIX a natureza não só passa a ser acolhida como uma manifestação de beleza, mas também como objeto de conhecimento, fonte de matérias-primas e de amplo palco de extensas relações entre fenômenos naturais interligados, interdependentes e cíclicos". Wilton Carlos Lima da Silva. As terras inventadas..., op. cit., p. 217.
} 
Ao tratarem da realidade paulista eles tinham como referência o ideal de modernidade, que abarcava o trabalho disciplinado, o controle e a concepção linear do tempo, a condenação do ócio e a maximização da produção para aumento do lucro ${ }^{78}$.

Através da leitura dos relatos podemos ver como se faz presente a ótica econômica e utilitarista dos viajantes ingleses e norte-americanos em diferentes períodos em que estiveram em São Paulo. Realizamos a seleção dos autores e das obras pelo fato de suas viagens e observações terem sido realizadas em intervalos de tempos regulares, de 10 a 15 anos, e ocorridas entre 1808 e 1865. Depois, com o predomínio do café nas balanças comerciais paulistas, que vinha ocorrendo paulatinamente desde meados do século XIX, e das mudanças impressas nas feições de São Paulo com esta cultura ${ }^{79}$, o conteúdo dos relatos de viagem passa a ter outras intenções.

No relato de Kidder e Fletcher temos a viagem do último à fazenda cafeeira Ibicaba do Senador Vergueiro, em Limeira, mas o objetivo de sua visita e a análise da região não recaem especificamente sobre o café, e com isto a obra destes viajantes faz parte no nosso corpus documental.

A nova complexidade do meio econômico e social e a hegemonia do café como tema, sendo visto sob diversos prismas nos relatos de viagem, exigem uma outra análise específica sobre o período. E as regiões paulistas percorridas pelos viajantes selecionados estavam localizadas próximas do litoral onde havia maior densidade populacional, não abarcando grande parte daquelas onde haveria a expansão e a hegemonia da lavoura

\footnotetext{
${ }^{78}$ José Carlos Barreiro ao analisar os relatos dos viajantes estrangeiros no Brasil aponta o referencial cultural da modernidade de valorização da propriedade privada e exaltação do trabalho disciplinado como uma lente, presente sistematicamente nestes registros ao tratarem e caracterizarem a sociedade brasileira e as classes subalternas. E vai além, apresentando que estes referências estão presentes na sociedade brasileira do século XX: "A substância básica das formas erradias, difusas e de intensa vibração cultura que formava a essência da cidade brasileira desde o período colonial ficou submergida por um projeto de modernidade, cujos ecos estenderam-se por mais de dois séculos. Os desdobramentos desse imaginário sobre a ação dos primeiros reformadores urbanos foram bastante eficazes. As reformas do Recife e Rio de Janeiro de inícios do século XIX são exemplares, sobretudo pelas conseqüências funestas trazidas à população pobre. As linhas de força desse imaginário permanecem um século depois, nas reformas urbanas de início do período republicano. A razão funcional que orientou o projeto desenvolvimentista da construção de Brasília parece ter sido o prolongamento mais recente do sonho autocrático e disciplinador que os viajantes nutriam sobre a organização da cidade e seus habitantes". José Carlos Barreiro. Imaginário e viajantes no Brasil do século XIX..., op. cit., p. 223.

${ }^{79}$ Os limites da expansão cafeeira paulista começaram a ser definidos no final da década de 1850 , e nos anos de 1870 já estava claramente demarcado. Segundo Alice Canabrava "nos seus últimos anos, as numerosas freguesias fundadas nos sertões do Oeste apontavam os limites alcançados pela extensão máxima das culturas de café na Província de São Paulo: Piraju, 1871; São Pedro do Turvo, 1875; Campos Novos Paulistas, São Manuel e Bauru, 1880; Jaú, 1858; São José do Rio Preto, 1879; Barretos, 1874; Ribeirão Preto, 1870”. Alice Canabrava. A grande lavoura. In.: Sérgio Buarque de Holanda (org.). O Brasil monárquico: declínio e queda do Império..., op. cit., p. 92.
} 
cafeeira. A seguir temos o "Mapa da Província de São Paulo (1868)"," elaborado por Candido Mendes, e nele podemos ver estas questões.

${ }^{80}$ Candido Mendes. Mapa da Província de São Paulo (1868). In.: Candido Mendes. Atlas do Império do Brazil (1868). Rio de Janeiro: Arte \& História, Livros e Edições, 2000, mapa XVII. 


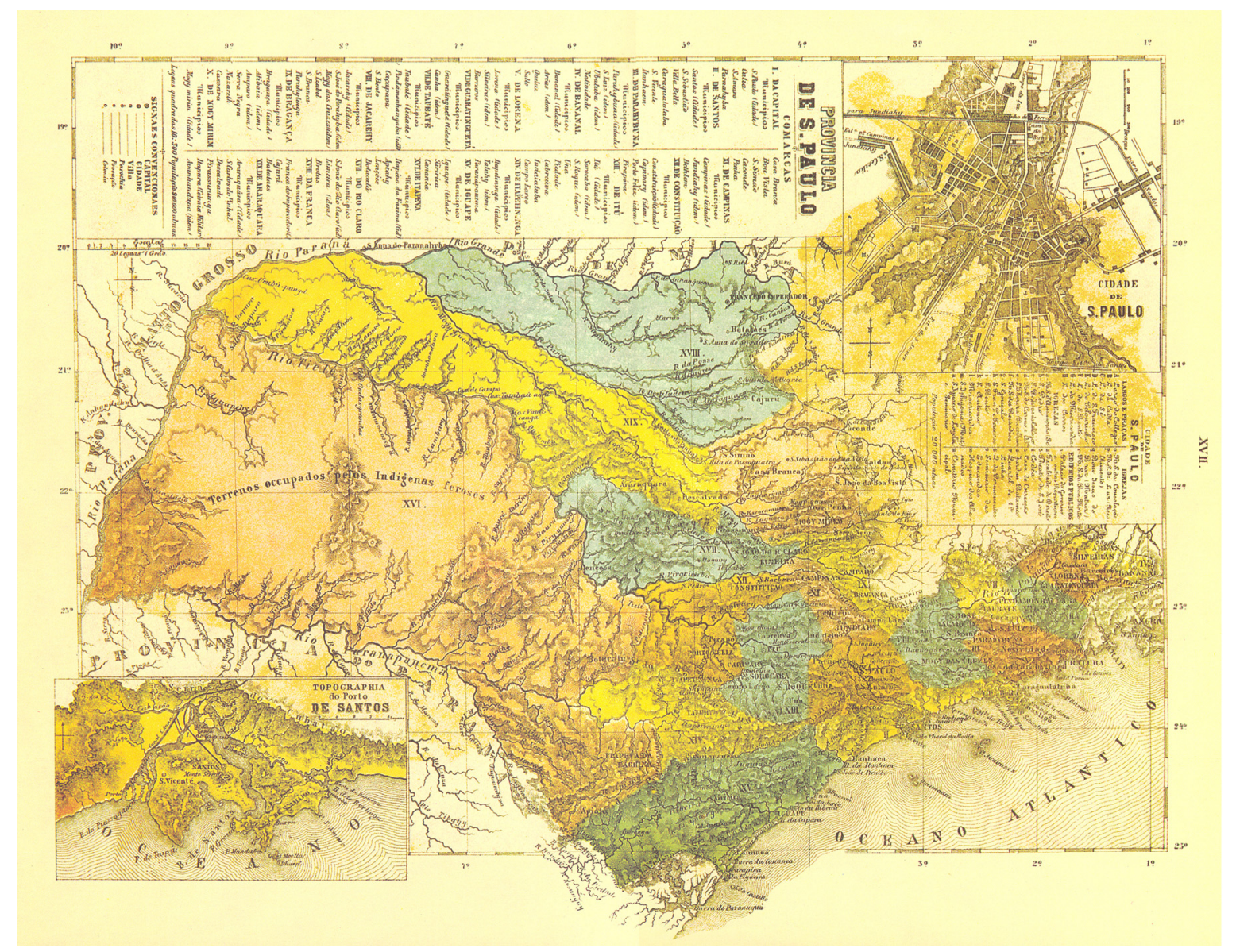




\subsection{As edicões dos relatos de viagem}

Ao longo do século XIX os relatos de viagem foram divulgados por um florescente mercado editorial, e acolhidos pelo público europeu e norte-americano ${ }^{81}$ interessados em conhecer as terras luso-brasileiras e a vida nestas paragens ${ }^{82}$. Na Inglaterra, as obras impressas puderam ser lidas em um número maior de bibliotecas, conforme aponta Manuel Portela, com base nas informações compiladas por Robin C. Alston, o número daquelas recenseadas foram: de 1600 a 1699, havia 1.177 unidades; de 1700 a 1799, 3.071 e, de 1800 a $1899,7.683^{83}$.

Do final de 1807 a 1811 o inglês John Mawe esteve no território da América Portuguesa e sobre sua viagem escreveu o relato Travels in the interior of Brazil, particularly in the Gold and Diamond Districts, by authority of the Prince Regent of Portugal. Including a Voyage to the Rio de la Plata and a Historical Sketch of the Revolution of Buenos Aires. Illustrated with engravings. By John Mawe, author of the Treatise on the "Mineralogy of Derbyshire". A primeira edição ocorreu em 1812 na Inglaterra, com 368 páginas e 9 estampas, sendo uma colorida, pela Longaman, Hurst, Rees, Orme \& Brown, Paternoster-Row, e em 1821 houve a segunda edição inglesa. No intervalo entre estas edições a obra foi impressa no ano de 1816 na Filadélfia, Estados Unidos, com duas tiragens. No mesmo ano foi traduzida para o francês e alemão. Em 1817 foi traduzido para o holandês e o italiano, e nesta edição foi apresentada a gravura da

\footnotetext{
${ }^{81}$ Flora Süssekind aponta o importante papel desempenhado pelos viajantes estrangeiros e seus relatos na constituição do narrador na prosa de ficção brasileira. Com isto, não somente havia a repercussão dessas obras como os "interlocutores não eram ingênuos, os letrados locais, leitores dos relatos de viagem pelo Brasil, não os liam à toa, mas com olhar de colecionador semelhante ao que lançavam tais viajantes para as cenas de natureza nos trópicos”. Flora Süssekind. O Brasil não é longe daqui..., op. cit., p. 127.

${ }^{82}$ No Rio de Janeiro, durante o Império, os livros de viagem também se destacavam nas coleções e nas estantes. Em 1827, na Livraria Plancher situada na Rua do Olvidor, n. 95, no Rio de Janeiro, de propriedade do francês Pierre-René-François Plancher de la Noé, os catálogos ofertavam 317 títulos. Sobre suas temáticas, Marco Morel aponta que "a História formava o principal filão editorial: somada à Política, compunha quase metade do acervo da livraria. Que tipo de História se escrevia? O item mais citado eram as Memórias, seguido dos livros de Viagem, Geografia e Cartografia. Havia também a História Moderna (por Estados nacionais), e as Biografias, ficando em último lugar, na quantidade, a História eclesiástica. Quanto à Política propriamente, subdividia-se em Teoria Política, Constituições, Relações entre Estados, Manifestos e Relatórios". Marco Morel. As transformações dos espaços públicos..., op. cit., p. 38.

${ }^{83}$ Manuel Portela. O comércio da literatura. Mercado e representação. Ensaio. Lisboa: Antígona, 2003, p. 75. apud. Marisa Midori Deaecto. No Império das Letras: circulação e consumo de livros na São Paulo oitocentista. Tese de doutorado. Departamento de História/Faculdade de Filosofia, Letras e Ciências Humanas/Universidade de São Paulo, 2005, p. 251-252. Segundo a autora, "Manoel Portela se vale de informações compiladas por Robin C. Alston, para o projeto The Library Database, http://www.ralston.co.uk",
} 
Mulher Paulista analisada acima. E em Estocolmo houve a publicação do relato pela Tryckt hos E. A. Ortman, em $1820^{84}$.

Em Lisboa, a tradução portuguesa foi publicada no ano de 1819 pela Imprensa Régia com o título Viagens ao interior do Brasil, com huma exacta descripção das Ilhas dos Açores, por João Mawe, Inglez. Authorizadas pelo Rei Fideslissimo D. João VI, Nosso Senhor, a beneficio da Livraria do Convento de S. Francisco da Cidade, obra promovida pelo R. P. M. Fr. Polidoro de N. S. da Lapa, leitor de Theologia e Bibliothecario da mesma. Esta edição foi traduzida do exemplar francês, já que nela consta Descrição das Ilhas dos Açores. A Viagem ao Rio da Prata e a Narrativa da revolução de Buenos Aires foram retiradas.

No ano de 1922, pela Imprensa Oficial do Estado de Minas Gerais os capítulos que tratam das terras mineiras foram traduzidos por Demeval Lessa, e intitulados Publicações do Centenário em Minas Gerais: Collectanea de scientistas extrangeiros (assumptos mineiros) organizada pelo Prof. Rodolpho Jacol. Vol. Mawe. Trad. de Demeval LessaEschwege (Pluto Brasiliensis) trad. de Rodolpho Jacob.

Em 1944, o relato foi publicado pela carioca Zélio Valverde, e por sua vez contou com a tradução de Solena Benevides, introdução e notas de Clado Ribeiro de Lessa, e foi intitulado Viagens ao interior do Brasil, principalmente aos distritos do ouro e dos diamantes. Nele encontramos reproduzida a capa da primeira edição inglesa de 1812 e também as imagens Lavagem de ouro no Jaraguá nas cercanias de São Paulo, Maquinaria, Itinerário do autor e Gravura dos cristais de diamante, topázio e turmalina, seguida da sua explicação. Da edição italiana de 1817 temos Trajes usados pelas paulistas $^{85}$. Esta edição foi a base para a de 1978 publicada pela Editora Itatiaia de Belo Horizonte e a Editora da Universidade de São Paulo, e nela todavia foram inclusas somente o Itinerário do autor e Gravura dos cristais, sendo omitida as outras imagens.

Além do seu relato de viagem, Mawe escreveu uma memória intitulada On a Gold Mine in South America, conservada na biblioteca da Geological Society, em Londres. É autor também de inúmeros trabalhos sobre a mineralogia e geologia, e no que diz respeito às pedras preciosas brasileiras tratou-as em $A$ treatise on diamonds and precious Stones, including their history - natural and commercial, to whisch is added some account of the

\footnotetext{
${ }^{84}$ Para o levantamento das edições das obras de John Mawe além dos dados obtidos através de nossas leituras, utilizamos a Introdução de Clado Ribeiro de Lessa em John Mawe. Viagens ao interior do Brasil..., op. cit., p. 15-20; e o banco de dados da Library of Congress online catalog em: http://catalog.loc.gov.

${ }^{85}$ John Mawe. Viagens ao interior do Brasil, principalmente aos distritos do ouro e dos diamantes. Trad. Solena Benevides Viana. Introd. e notas de Clado Ribeiro de Lessa. Rio de Janeiro: Zélio Valverde, 1944.
} 
best methods of cutting and polishing them, impressa pelo mesmo editor de Viagens no Brasil, um ano após o relato, em 1813, e com a segunda edição de 1823.

No ano de 1840, retornava aos Estados Unidos o pastor metodista Daniel Parish Kidder, no Brasil desde 1837. Sua viagem é relatada em Sketches of residence and travel in Brazil, dividida em dois volumes. No primeiro trata do Rio de Janeiro e São Paulo e no segundo volume as províncias do norte. A primeira edição se deu em 1845, concomitantemente em Londres pela Wiley \& Putnam, e na Filadélfia pela Sorin and Ball $^{86}$.

A parte do relato referente à Pernambuco foi traduzida para o português por Alfredo de Carvalho, e impressa nos números 75 e 89 da Revista do Instituto Arqueológico e Geográfico Pernambucano como Impressões de um Missionário Metodista em Pernambuco $^{87}$.

A tradução integral da obra foi feita por Moacir Vasconcelos e editada em 1940 pela Livraria Martins, com o título de Reminiscências de viagens e permanência no Brasil (Rio de Janeiro e Província de São Paulo): compreendendo notícias históricas e geográficas do Império e de diversas províncias. Em 1943 apresentou também a edição da obra referente às Províncias do Norte. No ano de 1980 o relato foi co-editado pela Editora Itatiaia e Edusp e, publicado na Coleção Reconquista do Brasil, nova série, com o mesmo título da edição de 1940. No ano de 2001 houve outra edição pelo Senado Federal.

Kidder escreve seu relato de viagem quando percorre as terras brasileiras entre 1837 a 1840, é co-autor de $O$ Brasil e os brasileiros, e tradutor de uma brochura do padre Feijó que trata do celibato clerical ${ }^{88}$.

\section{O relato Brazil and the Brazilians (Portrayed in Historical and Descriptive} Sketches) escrito por Kidder com James Colley Fletcher, também pastor metodista e norteamericano, contou com diversas edições ${ }^{89}$. O relato é o resultado da viagem de Fletcher

\footnotetext{
${ }^{86}$ Rubens Borba de Morais. Introdução. In.: Daniel Parish Kidder. Reminiscências de viagens..., op. cit., p. 15-16. Além das leituras realizadas para o levantamento das edições do relato de Daniel Kidder, pesquisamos os bancos de dados da Fundação Biblioteca Nacional em www. bn.br/portal/; do Sistema de Bibliotecas da Unicamp em www.unicamp.br/bc/; do Sistema de Bibliotecas da PUC/SP em http://lumen.pucsp.br; e da Library of Congress online catalog em: http://catalog.loc.gov.

${ }^{87}$ Notas bio-biográficas de Edgard Süssekind de Mendonça. In.: D. P. Kidder e J. C. Fletcher. O Brasil e os brasileiros..., op. cit., vol. 1, p. X.

${ }^{88}$ Daniel Parish Kidder também é autor de livros religiosos. Uma série de obras do viajante está catalogada na Library of Congress em: http://catalog.loc.gov.

${ }^{89}$ Os dados relativos às edições do relato de Daniel Kidder e James Fletcher, O Brasil e os brasileiros..., foram obtidas a partir de nossas leituras, nas Notas bio-biográficas de Edgard Süssekind de Mendonça. In.: D. P. Kidder e J. C. Fletcher. O Brasil e os brasileiros..., op. cit., vol. 1, p. IX-X; e nos bancos de dados da Fundação Biblioteca Nacional em www. bn.br/portal/; do Sistema de Bibliotecas da Unicamp em
} 
pelo Brasil nas décadas de 1850 e 1860, com pequenas interrupções, quando agregou suas experiências às obtidas anos antes por Kidder e que foram apontadas no relato Reminiscências de viagem e permanência...

A primeira edição foi feita em 1857 na Filadélfia, pela Childs \& Petersons. Entre 1858 a 1866 o relato contou com a $2^{\mathrm{a}}, 3^{\mathrm{a}}, 4^{\mathrm{a}}$ e $5^{\mathrm{a}}$ edições pela mesma editora do ano anterior e pela Little, Brown de Boston. De 1866 a 1868, pela Child \& Peterson, houve anualmente publicações da obra, compreendendo a $6^{\mathrm{a}}, 7^{\mathrm{a}}$ e $8^{\mathrm{a}}$ edições. Segundo Edgard Süssekind de Mendonça, José Carlos Rodrigues refere-se à 9 edições, e Alfredo de Carvalho fala de 12 edições.

O relato foi traduzido para o português por Elias Dolianiti, em 1941, e publicado pela Companhia Editora Nacional na Coleção Brasiliana com o título O Brasil e os brasileiros (Esboço Histórico e Descritivo), em dois volumes.

Kidder e Fletcher escrevem no prefácio da $6^{\text {a }}$ edição sobre o expressivo número de edições: “A favorável acolhida que tiveram as cinco edições anteriores da presente obra nos Estados Unidos, na Inglaterra e no Brasil, demonstra um interesse crescente pela maior e mais estável das nações sul-americanas" $"$.

Fletcher também escreveu International relations with Brazil. Proceeding on the reception of H. E. Senhor d'Azambuja, Envoy Extraordinary and Minister Plenipotenciary from Brazil by the Chamber of commerce of the state of New-York, publicada em Nova York pela John Ammermann, no ano de 1865.

Para Tania Quintaneiro os relatos de viagem foram bem acolhidos e permearam a vida dos estadunidenses, pois "o dia-a-dia americano cristalizava-se em diários, relatórios comerciais e diplomáticos, tratados de história natural e geografia e até em roteiros turísticos que iam chegando às mãos dos que pretendiam trilhar os mesmos caminhos, assim como dos que só viriam a sair de suas casas por meio da imaginação"91.

A viagem do inglês Edmund Pink por São Paulo em 1823 e registrada no seu Journal of an Excursion taken - from Rio de Janeiro in the Year 1823 - in Company with $F$. F. ae though a portion of the province of $S$. Pauls ficou manuscrita e sem tradução até o ano de 2000, quando a Bovespa tornou público o relato que contou com a transcrição

www.unicamp.br/bc/; do Sistema de Bibliotecas da PUC/SP em http://lumen.pucsp.br; e da Library of Congress online catalog em: http://catalog.loc.gov.

${ }^{90}$ D. P. Kidder e J. C. Fletcher. O Brasil e os brasileiros..., op. cit., vol. 1, p. XVII.

${ }^{91}$ Tania Quintaneiro. Retratos de mulher: a brasileira vista por viageiros ingleses e norte-americanos durante o século XIX. Petrópolis (RJ): Vozes, 1995, p. 18. 
paleográfica e a tradução de Cristina Antunes ${ }^{92}$, e a CBA como editora. O relato e suas aquarelas fazem parte da obra A São Paulo de Edmund Pink ${ }^{93}$.

Em 1865 o inglês Aubertin percorreu a região algodoeira paulista e escreveu sobre sua viagem uma carta ao Barão de Piracicaba, publicada em São Paulo no ano de 1866 pela Typ. Allemã de H. Schroeder, com o título Onze dias de viagem na Província de São Paulo com os Srs. Americanos Drs. Gaston e Shaw, e o Major Mereweather. 1865. Carta dirijida ao Illm. e Exm. Sr. Barão de Piracicaba por J. J. Aubertin. Superintendente da Estrada de Ferro de São Paulo.

No banco de dados da The Library of Congress consta a obra Eleven days' journey in the province of Sao Paulo, com publicação de Bates-Hendy, em 1868, Londres. E o autor é J. J. Aubertin, que corresponde a John James Aubertin ${ }^{94}$.

Alice Canabrava no seu trabalho $O$ algodão em São Paulo ${ }^{95}$ aponta a existência de artigos escritos por Aubertin para os jornais Correio Paulistano, Diário de S. Paulo e Revista Commercial, e destaca que a sua correspondência versava sobretudo sobre a situação da lavoura algodoeira em São Paulo.

As diversas edições dos relatos nos apresentam o interesse do público pelas narrativas de viagens. Segundo Rouanet, este quadro se dá pela necessidade de divulgação e correção das informações apresentadas nas obras, o crescimento do mercado dos livros de viagem e, pela ampliação dos processos de colonização para os países envolvidos nas

\footnotetext{
${ }^{92}$ No banco de dados da Library of Congress consta que a tradução foi feita por Cristina Antunes e John Gledson. Em: http://catalog.loc.gov.

${ }^{93}$ Edmund Pink. A São Paulo de Edmund Pink..., op. cit.

${ }^{94}$ Os dados sobre Aubertin são contraditórios. Durante nossas pesquisas seu nome foi apontado no banco de dados da Library of Congress como sendo John James Aubertin, e por Alice Canabrava como sendo Jean Jacques Aubertin. Sobre sua nacionalidade, encontramos informações que dizem ser J. J. Aubertin inglês, como consta na Grande Enciclopédia Portuguesa e Brasileira, Verbo - Enciclopédia Luso-Brasileira de Cultura, no trabalho de Alice Canabrava e na obra de Gilberto Freyre. Já na Paulistania, edições 53-72, encontramos, na página 19, que J. J. Aubertin é o engenheiro francês Jean Jacques Aubertin (tal informação foi retirada de: www.book.google.com.br). Com base nos dados apresentados nestas obras e no relato de viagem, em nosso trabalho consideramos ser inglesa a nacionalidade de J. J. Aubertin. Alice Canabrava. $O$ algodão em São Paulo..., op. cit.; Gilberto Freyre. Ingleses no Brasil. Aspectos da influência britânica sobre a vida, a paisagem e a cultura do Brasil. Rio de Janeiro: Livraria José Olympio, 1948, p. 88; Grande Enciclopédia... Lisboa; Rio de Janeiro: Editorial Enciclopédia, s/d, p. 704, vol. 3; Verbo - Enciclopédia Luso-Brasileira... Lisboa: Editorial Verbo, 1960, p. 1803, vol. 2; Library of Congress online catalog, em: http://catalog.loc.gov; J. J. Aubertin. Onze dias de viagem na Província de São Paulo.., op. cit.

${ }^{95}$ Alice Canabrava. O algodão em São Paulo..., op. cit.
} 
expedições e viagens ${ }^{96}$. Também por meio destas obras os leitores podem entrar em contato com outras formas de habitar o mundo ${ }^{97}$.

\footnotetext{
${ }^{96}$ M. Rouanet. Eternamente em berço esplêndido. São Paulo: Siciliano, 1991, p. 88. apud. Wilton Carlos Lima da Silva. As terras inventadas..., op. cit., p. 166.

${ }^{97}$ Mary Louise Pratt ao abordar os relatos, em especial os escritos no século XVIII, aponta: "Os relatos jornalísticos e a narrativa de viagem, contudo, eram mediadores essenciais entre a rede científica e o público europeu mais amplo, pois eram agentes centrais na legitimação da autoridade científica e de seu projeto global, ao lado de outras formas européias de ver o mundo e habitá-lo". Mary Louise Pratt. Os olhos do Império..., op. cit., p. 63.
} 


\section{Capítulo 2. Os olhares de John Mawe, Edmund Pink e Daniel Kidder sobre São Paulo}

Este capítulo tem o intuito de compreender como o filtro utilitarista e econômico se faz presente nos relatos do inglês John Mawe ${ }^{98}$, de seu conterrâneo Edmund Pink ${ }^{99}$ e do norte-americano Daniel Parish Kidder ${ }^{100}$ que estiveram na Capitania e depois Província de São Paulo na primeira metade do século XIX.

Mawe chegou a terras luso-americanas após uma viagem com fins comerciais ao Rio da Prata feita em 1804. Em Montevidéu ele, seu navio e sua carga foram capturados. Quando solto, em finais de 1807, e munido de uma carta de apresentação fornecida pelo embaixador português em Londres, seguiu rumo ao Rio de Janeiro:

“Ao voltar a Montevidéu, não perdi tempo em pôr em execução minha planejada viagem ao Rio de Janeiro, e, tendo notícias de que não seria

\footnotetext{
98 “John Mawe nasceu em Derbyshire em 1764. Durante a mocidade gastou 15 anos em viagens marítimas. Pelos fins do século XVIII, percorreu a maioria das minas da Inglaterra e da Escócia à cata de exemplares mineralógicos para a coleção do rei da Espanha. Em agosto de 1804 partiu para uma viagem ao Rio da Prata. Chegou a Cádiz por ocasião do rompimento da guerra entre a Inglaterra e a Espanha, ficando retido na cidade, onde adoeceu e escapou de morrer. Velejou de Cádiz em março de 1805 para Montevidéu, e, ao desembarcar foi preso como espião inglês. Conseguiu libertar-se pouco depois, mas foi internado, e só pode recuperar a liberdade de locomoção quando da captura da cidade pelo general Beresford em 1806. Acompanhou a expedição a Buenos Aires comandada pelo General Whitelocke e, de regresso a Montevidéu, fretou um barco e zarpou para o Brasil, escalando em vários portos. Foi bem recebido no Rio de Janeiro pelo Príncipe Regente D. João, que lhe concedeu permissão para visitar as jazidas de diamantes de Minas Gerais e outras regiões do interior, durante os anos de 1809-1810, facultando-lhe, outrossim, a consulta dos arquivos públicos. Mawe voltou a Londres em 1811, abriu loja na Strand (Margem do Tamisa) perto de Summerset House, e adquiriu grande renome como perito conhecedor de minerais e pedras preciosas em particular. Faleceu nessa cidade a 26 de Outubro de 1829. Uma lápide em sua memória foi colocada na igreja de Castleton, no Derbyshire. Seu negócio continuou sob a direção do mineralogista James Tennant”. In.: Bernardo Barham Wooodward. Dictionary of National Biography. t. XIII, pp. 110-111. apud. Clado Ribeiro de Lessa. Introdução. In.: John Mawe. Viagens ao interior do Brasil..., op. cit., p. 16.

99 "Pouco se sabe a respeito da vida de Edmund Pink. A única informação oficial que se tem dele no Brasil é a data de sua partida, de volta a Londres, em 1825. No registro consta que em 15 de setembro desse ano, Edmund Pink, comerciante inglês, de 23 anos, de estatura comum, rosto claro, farta barba e cabelos avermelhados, partira para Inglaterra. Por meio desse documento foi possível estabelecer a data de nascimento do aquarelista - 1802. [...] Seja como for, ele veio ao Brasil em 1821 para trabalhar como associado da empresa G.T. Standfast \& Co., de propriedade de George Thomas Standfast, localizada na rua do Rosário, centro do Rio de Janeiro, e estabelecida no país entre 1816 e 1825, quando encerrou suas atividades". Notas biográficas. In.: Edmund Pink. A São Paulo de Edmund Pink..., op. cit., p. 21.

${ }^{100}$ Daniel Parish Kidder nasceu em 18 de outubro de 1815, em Darien, Estado de New York. Passou grande parte da meninice na casa dos tios em Vermont. Estudou em diversos colégios. Formou-se na Wesleyan University em 1836. Embora não fosse de família metodista, contrariando a vontade do pai converteu-se e resolveu ser pastor. Pretendeu ir para China como missionário, não o conseguindo, resolveu aceitar, da American Bible Society, um cargo de missionário no Brasil. Embarcou na companhia de sua esposa Cynthia H. Russel em 1837 e em 1840 devido ao falecimento dela retornou aos Estados Unidos. Atuou como pastor em Paterson e Trenton, secretário de escolas - sendo também diretor de publicações especiais destas unidades de ensino - e professor de teologia no Garret Biblial Institute Institute (Evanston, Illinois) e no Drew Theological Seminary (Madison, Nova York). Em 1880 foi eleito membro da Comissão de Educação da Igreja Metodista, tendo escrito diversas obras. No ano de 1887 com problemas de saúde, aposentou-se e foi residir em Evanston, perto de Chicago, onde faleceu em 29 de julho de 1891, deixando viúva Hariett Smith, com quem se casara, pela segunda vez, em 1842. Rubens Borba de Morais. Introdução. In.: Daniel Parish Kidder. Reminiscências de viagem e permanência nas Províncias do Sul do Brasil..., op. cit., p. 15-16.
} 
muito difícil a entrada de um navio inglês naquele porto, fretei um barco português, chamado 'Vencedor', e a mim se reuniram vários cavalheiros, cujos negócios reclamavam sua presença na capital do Brasil" $"$ 101.

Sua vinda ocorreu no contexto da transferência da Família Real Portuguesa e da abertura dos portos às nações amigas. Em decorrência das alianças entre Portugal e Inglaterra, a última detinha a hegemonia sobre as relações comerciais e, conseqüentemente no número de embarcações nos portos recém abertos. Na Tabela 1 abaixo podemos visualizar o aumento do número dos navios no porto do Rio de Janeiro entre 1791 e $1810^{102}$, com o predomínio das embarcações britânicas e portuguesas:

TABELA 1 - Navios ancorados no porto do Rio de Janeiro - 1791-1810

\begin{tabular}{|c|c|c|c|c|}
\hline $1791=9$ & $1795=26$ & $1799=39$ & $1803=54$ & $1807=47$ \\
\hline $1792=34$ & $1796=16$ & $1800=70$ & $1804=54$ & $1808=70$ \\
\hline $1793=29$ & $1797=24$ & $1801=64$ & $1805=38$ & $1809=83$ \\
\hline $1794=19$ & $1798=27$ & $1802=51$ & $1806=59$ & $1810=122$ \\
\hline
\end{tabular}

FONTE: Ernest Pijning. A new interpretation of contraband trade. HAHR, aug./nov. 2001, p. 82; Roberto Simonsen. História econômica do Brasil (1500-1820). São Paulo: Companhia Editora Nacional, 1969, p. 440. apud. José Jobson de Andrade Arruda. Uma colônia entre dois impérios: a abertura dos portos brasileiros. 1800-1808. Bauru (SP): EDUSC, 2008, p. 116.

Do final de 1807 ao início de 1808 esteve em São Paulo e interrompeu sua estada com a notícia da chegada da Família Real, seguindo para a capital carioca a fim de obter alguma ocupação junto à Corte. No Rio de Janeiro, entregou sua carta de apresentação, e "algumas semanas após a minha chegada, pedi permissão a Sua Excelência o Conde de Linhares para trabalhar numa mina de ferro em Guaraciaba, fazendo-lhe ver, ao mesmo tempo, as imensas vantagens que adviriam para o Estado de tal experiência, ao explorar os seus próprios recursos, para suprimento daquele metal. Ele concordou, em parte, com a proposta, mas manifestou desejo que eu dedicasse antes alguns dias a uma inspeção à fazenda do Príncipe, em Santa Cruz e, ao voltar, fizesse um relatório sobre as condições

\footnotetext{
${ }^{101}$ John Mawe. Viagens ao interior do Brasil..., op. cit., p. 51.

${ }^{102}$ Segundo José Jobson Arruda, tais dados apontam não só o aumento do número de navios no porto carioca após 1808, mas principalmente o período entre 1791-1792 como marco de uma mudança significativa na postura dos comerciantes brasileiros no sentido de praticarem o comércio ilegal mesmo sob a vigilância dos funcionários reais, em especial com seu consentimento, com destaque na prática do contrabando dos comerciantes ingleses. $\mathrm{O}$ foco desta atividade, segundo o autor, era o porto do Rio de Janeiro por concentrar $34,2 \%$ das exportações e $38,1 \%$ das importações. Assim, aponta a gradual abertura dos portos a partir de 1800 e sua formalização em 1808. José Jobson de Andrade Arruda. Uma colônia entre dois impérios: a abertura dos portos brasileiros. 1800-1808. Bauru (SP): EDUSC, 2008.
} 
em que a encontrara" ${ }^{\text {103 }}$. E assim, passou a realizar serviços para a Coroa, deixando o Brasil alguns anos depois, em 1811.

Após quinze anos da viagem de Mawe, o inglês Edmund Pink, no Brasil desde 1821, percorreu a Província de São Paulo, de 30 de maio a outubro de 1823. Segundo o viajante, seu objetivo era "uma viagem através dos distritos de açúcar" vinda, a lavoura canavieira era o principal produto paulista e a região de maior destaque era denominada o "quadrilátero do açúcar", formada por Sorocaba, Piracicaba, MogiGuaçu e Jundiai ${ }^{105}$. Estas localidades e suas vizinhanças foram o foco da sua visita ${ }^{106}$.

TABELA 2 - Localidades visitadas por Edmund Pink - 1823

\begin{tabular}{|l|l|l|}
\hline \multicolumn{1}{|c|}{ Localidade } & Distância percorrida & \multicolumn{1}{c|}{ Tempo de Permanência } \\
\hline Santos & * Desembarque & 31 de maio a 5 de junho de 1823 \\
\hline Cubatão & 2 léguas & 6 de junho de 1823 \\
\hline Ponte Alta & 4 léguas & 6 e 7 de junho de 1823 \\
\hline Cidade de São Paulo & 5 léguas & 7 de junho a 26 de junho de 1823 \\
\hline Jacaré (sic) & Não há dados & 26 e 27 de junho de 1823 \\
\hline Jundiaí & 10 léguas & 27 e 28 de junho de 1823 \\
\hline Campinas & 8 léguas & 28 de junho a 30 de junho de 1823 \\
\hline Mogi - Mirim & 10 léguas & 30 de junho a 8 de julho de 1823 \\
\hline Campinas & 17 léguas & 9 e 10 de julho de 1823 \\
\hline Itu & 9 léguas & 10 a 19 de julho de 1823 \\
\hline Porto Feliz & 6 léguas & 19 de julho de 1823 \\
\hline Fábrica S. João de Ipanema & 4 léguas & 20 a 23 de julho de 1823 \\
\hline Sorocaba & 4 léguas & 23 a 26 de julho de 1823 \\
\hline Vila de Santa Rocha & Não há dados & 26 e 27 de julho de 1823 \\
\hline Cidade de São Paulo & Não há dados & 27 de julho a 21 de outubro de 1823 \\
\hline Mogi das Cruzes & Não há dados & 22 a 24 de outubro de 1823 \\
\hline Freguesia de N. S. da Escada & Não há dados & 24 e 25 de outubro de 1823 \\
\hline Jacaré́ & Não há dados & 25 e 26 de outubro de 1823 \\
\hline São José & Não há dados & 26 a 29 de outubro de 1823 \\
\hline
\end{tabular}

FONTE: Tabela elaborada com base no relato do viajante Edmund Pink. A São Paulo de Edmund Pink. São Paulo: CBA, 2000, p. 81-97.

\footnotetext{
${ }^{103}$ John Mawe. Viagens ao interior do Brasil..., op. cit., p. 86.

${ }^{104}$ Edmund Pink. A São Paulo de Edmund Pink..., op. cit., p. 86.

${ }^{105}$ Maria Thereza Schorer Petrone. A lavoura canavieira em São Paulo. Expansão e declínio (1765-1851). São Paulo: Difusão Européia do Livro, 1968, p. 24.

106 "Ao contrário dos exploradores e naturalistas, estes viajantes da década de 1820 não registraram realidades que supunham novas; não se apresentaram como descobridores de um mundo primal; e os fragmentos de natureza que coletavam eram amostras de matérias primas, não fragmentos dos desígnios cósmicos da natureza. Em seus escritos, a retórica contemplativa e estetizante da descoberta é freqüentemente substituída por uma retórica de consecução de objetivos, de conquista e realizações. Em muitos relatos, o próprio itinerário torna-se a oportunidade para uma narrativa de sucesso, na qual a viagem é, em si, um triunfo". Mary Louise Pratt. Os olhos do império..., op. cit., p. 256.
} 
A cultura canavieira em São Paulo tornou-se um empreendimento visando o mercado mundial principalmente a partir do governo de Luiz Antonio de Sousa Botelho Mourão - o Morgado de Mateus, que governou a Capitania restaurada entre 1765 a $1775^{107}$, e a infra-estrutura para a produção e exportação do açúcar iniciada neste período foi realizada, sobretudo, até o governo de Antonio Manuel de Mello Castro e Mendonça, de 1797 a $1802^{108}$.

Conforme Maria Thereza Petrone, ao longo do final do século XVIII e início do XIX houve o aumento da cultura canavieira paulista devido, principalmente, a três fatores: internamente passou a contar com o incentivo administrativo visando sua exportação, externamente houve a maior procura do açúcar brasileiro pelo mercado europeu ${ }^{109}$ e a relação Metrópole e Colônia passou por uma transformação a partir de 1808 com a mudança da sede do Império Português ${ }^{110}$.

Concomitantemente ao crescimento do comércio passou a haver o reconhecimento do território de São Paulo e, em âmbito internacional, este movimento passou a influenciar o imaginário europeu no final do século XVIII sobre a constituição das terras paulistas ${ }^{111}$. Os mapas elaborados representavam, visualmente, o poder político e econômico constituído ${ }^{112 \mathrm{a}-\mathrm{b}}$.

\footnotetext{
${ }^{107}$ Maria Thereza Schorer Petrone. A lavoura canavieira em São Paulo..., op. cit., p. 12.

108 Ibidem, p. 223.

${ }^{109}$ Maria Thereza Schorer Petrone. A lavoura canavieira em São Paulo..., op. cit., p. 18. O aumento da procura do açúcar brasileiro pelo mercado internacional tem como um dos fatores a desarticulação da produção açucareira nas possessões francesas. Sobre este aspecto aponta Virgílio Noya Pinto "tendo permanecido em estado letárgico durante a maior parte do século XVIII, o açúcar sofrera nos fins daquele século revalorização no mercado internacional, graças às lutas coloniais em torno da Revolução Francesa, nas Antilhas, com a desarticulação de regiões produtoras, exemplificada pelo colapso da produção açucareira haitiana em 1792". Virgílio Noya Pinto. Balanço das transformações econômicas no século XIX. In.: Carlos Guilherme Mota (org.). Brasil em Perspectiva. 2. ed. São Paulo: Difusão Européia do Livro, 1969, p. 127. Francisco Luna e Herbert Klein escrevem a respeito do tema: "A alta dos preços internacionais, depois do colapso da produção de São Domingos em 1791, e o crescimento de uma pujante economia açucareira no Rio de Janeiro criaram uma demanda em constante expansão para a porção regional do Sudeste, que suplantaria o Nordeste como principal área produtora de açúcar no Brasil". Francisco Vidal Luna e Herbert S. Klein. Evolução da sociedade e economia escravista de São Paulo, de 1750 a 1850. São Paulo: Edusp, 2005, p. 57.

${ }^{110}$ Maria Thereza Schorer Petrone. A lavoura canavieira em São Paulo..., op. cit., p. 173.

${ }^{111}$ Airton José Cavenaghi. O território paulista na iconografia oitocentista: mapas, desenhos e fotografias. Análise de uma herança cotidiana. Anais do Museu Paulista: História e Cultura Material. v. 14, n. 1, jan./jun. 2006, p. 12. Disponível em www.scielo.br.

${ }_{112}$ A - Ibidem, p. 3.

B- Segundo Aírton Cavenagui "a produção cartográfica, ao mesmo tempo em que é considerada como fruto de uma análise científica do território, envolvendo uma seqüência de escalas e padrões de representação, pode e deve ser interpretada por outro viés: como uma representação mental, fruto de um momento social, político e econômico específico". Ibidem.

Neste período, o governador Bernardo José de Lorena (1788-1797) encarregou o Engenheiro Militar Antonio Roiz Montesinho de elaborar o mapa da Capitania de São Paulo, que foi intitulado "Mappa corographico da Capitania de S. Paulo (1791-1792)". Para Affonso Taunay, apesar das falhas, é "o primeiro ensaio completo
} 
Após quase cinco meses em terras paulistas, e depois de percorrer a região dos distritos açucareiros, Pink no dia 21 de outubro [1823] anunciou sua ida para o Rio de Janeiro. E em 15 de setembro de 1825 retornou a Londres.

A cultura canavieira continuava sendo o esteio econômico paulista quando Daniel Kidder desembarcou no Brasil. Uma série de acontecimentos favoreceu sua vinda para estas paragens. Internamente os Estados Unidos seguia sua política expansionista que anexou os territórios de Missouri, Oregon (reclamado pela Grã-Bretanha e Estados Unidos) e parte do México ${ }^{113}$. A descoberta do rio Columbia em terras estadunidenses atraiu inúmeros exploradores e o estabelecimento de companhias, e gerou uma onda migratória visando à fixação de norte-americanos, iniciada em 1834, e a ida de missionários metodistas para a região ${ }^{114}$.

O envio de missionários ultrapassou os limites dos Estados Unidos, com Beecher no comando da American Bible Society e seus associados estabelecendo uma ampla rede de sociedades missionárias e de caridade para espalhar os ensinamentos bíblicos pelas partes mais remotas do mundo ${ }^{115}$. Neste período, Daniel Kidder passou a seguir a doutrina metodista, e, em $1837^{116}$, foi enviado pela instituição bíblica como missionário para o Brasil. Em janeiro de 1839, o pastor metodista esteve em São Paulo na companhia de sua esposa Cynthia H. Russel, e devido ao falecimento dela decidiu voltar aos Estados Unidos em 1840.

para uma carta de conjunto da capitania de S. Paulo, cheio de elementos verídicos e excelentes". Collectanea de mappas da cartograhia paulista antiga. Abrangendo nove cartas, de 1612 a 1837, reproduzidas da collecção do Museu Paulista e acompanhadas de breves comentários por Affonso D'Escragnolle Taunay. São Paulo: Companhia Melhoramentos de S. Paulo, 1922, p. 6. Esta coletânea foi publicada na ocasião do Primeiro Centenário da Independência Nacional.

${ }^{113}$ Sobre a política expansionista dos Estados Unidos ver o trabalho de Samuel Eliot Morison e Henry Steele Commager. História dos Estados Unidos. São Paulo: Edições Melhoramentos, s/d, tomo 2.

${ }^{114}$ Antônia Fernanda Pacca de Almeida. Desafio americano à preponderância britânica no Brasil..., op. cit., p. 150.

${ }^{115}$ Luiz Estevam Fernandes e Marcus Vinícius de Morais. Os EUA no século XIX. In.: Leandro Karnal [et alli]. História dos Estados Unidos: das origens ao século XXI. São Paulo: Contexto, 2007, p. 120.

${ }^{116} \mathrm{Na}$ apresentação de Rubens Borba de Morais sobre Daniel Parish Kidder o ano de 1837 é considerado como sendo de embarque do norte-americano para o Rio de Janeiro. Todavia, Edgard Süssekind de Mendonça considera ter sido o ano de 1836 como da vinda de Kidder ao Brasil, baseando-se na obra de José Carlos Rodrigues Religiões acatólicas no Brasil, de 1900, e na Celebração de quatro aniversários da Igreja Metodista do Expositor Christão de 1936. Os apontamentos de Rubem Borba de Moraes estão em Daniel Parish Kidder. Reminiscências de viagem..., op. cit., p. 15-16. Sobre os dados assinalados por Edgar de Mendonça ver Dados Bio-bibliográficos, In.: P. Kidder e J. C. Fletcher. O Brasil e os brasileiros..., op. cit., vol. 1, p. IX a XVI. 
Durante sua permanência no Brasil, o gênero de maior destaque no comércio paulista, o açúcar e seus derivados, tinha como destino principal o porto de Santos ${ }^{117}$. A tabela 3 nos apresenta o valor em réis do café e do açúcar exportados no porto santista, e a predominância do último nas exportações:

TABELA 3 - Exportação de açúcar pelo porto de Santos - 1836-1842

\begin{tabular}{|l|l|l|}
\hline \multicolumn{1}{|c|}{ Ano Comercial } & \multicolumn{1}{|c|}{ Açúcar (arrobas) } & \multicolumn{1}{c|}{ Café (arrobas) } \\
\hline & \multicolumn{1}{|c|}{} \\
\hline $1836-1837$ & 433.268 & 87.659 \\
\hline $1837-1838$ & 297.041 e 18 libras & 97.751 e 10 libras \\
\hline $1838-1839$ & 490.019 e 2 libras & 113.965 \\
\hline $1839-1840$ & 570.779 e 26 libras & 136.524 e 28 libras \\
\hline $1840-1841$ & 533.142 e 6 libras & 184.976 e 2 libras \\
\hline $1841-1842$ & 444.318 & 184.976 e 2 libras \\
\hline
\end{tabular}

FONTE: Livro das exportações da Barreira de Cubatão, entrada de Santos. apud. Maria Thereza Schorer Petrone. A lavoura canavieira em São Paulo. Expansão e declínio (1765-1851). São Paulo: Difusão Européia do Livro, 1968, pp. 152-167.

NOTA: No ano de 1841, em decorrência de uma forte geada a lavoura canavieira e cafeeira foram seriamente prejudicadas, o que ocasionou uma queda abrupta no valor das exportações, principalmente no ano comercial seguinte.

No período as transações comerciais entre Brasil e Estados Unidos eram florescentes ${ }^{118}$. Também pelo porto de Santos importou-se dos Estados Unidos o valor em réis de 21:517\$300. Com base na tabela 4 abaixo percebemos o predomínio norteamericano entre as nações estrangeiras, com exceção da Argentina e de Portugal, tendo inclusive um montante final superior ao da Inglaterra.

\footnotetext{
${ }^{117}$ A política de favorecimento do porto de Santos para escoamento da produção açucareira paulista é analisada por Maria Thereza Schorer Petrone. A lavoura canavieira em São Paulo..., op. cit.; e Francisco Vidal Luna e Herbert S. Klein. Evolução da sociedade e economia escravista de São Paulo..., op. cit.

${ }^{118}$ Sobre a política norte-americana no Brasil e as relações comerciais entre os dois países durante o século XIX ver Antônia Fernanda Pacca de Almeida. Desafio americano..., op. cit.; Antônia Fernanda de Almeida Wright. Brasil - Estados Unidos. In.: Sérgio Buarque de Holanda (org.). História Geral da Civilização Brasileira. O Brasil monárquico: declínio e queda do Império..., op. cit., p. 171-203; Luiz Alberto Moniz Bandeira. Presença dos Estados Unidos no Brasil..., op. cit.
} 
TABELA 4 - Volume de importação do porto de Santos para o ano comercial de 1836-1837

\begin{tabular}{|c|c|c|}
\hline Origem & Produtos & Valor em réis \\
\hline Rio de Janeiro & $\begin{array}{l}\text { Fazendas secas e molhados, especiarias, louça, vidros, } \\
\text { drogas, ferragens e pólvora }\end{array}$ & 1.944:970\$110 \\
\hline Buenos Aires & Carne seca, couros, sebo, sabão e peles & $58: 312 \$ 560$ \\
\hline Pernambuco & Sal, vinho, pano de algodão, fazendas e especiarias & 41:513\$000 \\
\hline Lisboa & ---------- & $39: 820 \$ 680$ \\
\hline Porto & $\begin{array}{l}\text { Ferro e prata em obras, vinho, fazendas, } \\
\text { quinquilharias, sal e cera }\end{array}$ & $25: 024 \$ 232$ \\
\hline Nova York & Farinha de trigo, fazendas, vinho e louças & $21: 517 \$ 300$ \\
\hline Portsmouth & $\begin{array}{l}\text { Farinha, sal, vela de sebo, tábuas de pinho, breu e } \\
\text { bacalhau }\end{array}$ & $20: 261 \$ 512$ \\
\hline S. Catarina & Farinha, louça, cebola, tábua e feijão & $16: 195 \$ 960$ \\
\hline Paranaguá & Cal, farinha, carne seca, arroz, tábua e cabos de embé & 15:081\$000 \\
\hline Iguape & Arroz & $14: 506 \$ 700$ \\
\hline S. Sebastião & Aguardente, café, louça, telhas e fumo & $12: 378 \$ 870$ \\
\hline Ilha de Maio & Sal & $10: 748 \$ 000$ \\
\hline Tarragona & Vinho e calçados & $4: 678 \$ 000$ \\
\hline Monte Vídeo & Carne seca, couros, sebo, sabão e peles & $3: 980 \$ 490$ \\
\hline Rio S. Francisco & ---------- & $3: 567 \$ 800$ \\
\hline Ilha da Boa Vista & Sal & $3: 554 \$ 000$ \\
\hline Patagônia & Sal e drogas & $3: 066 \$ 000$ \\
\hline Ilha do Assú & Sal & $3: 055 \$ 000$ \\
\hline Bahia & $\begin{array}{l}\text { Fazendas, pano de algodão, massame, sabão, sal, ferro } \\
\text { em barra e em obras e vidro }\end{array}$ & $2: 735 \$ 500$ \\
\hline Guaratuba & ---------- & $1: 056 \$ 000$ \\
\hline Porto Bello & Farinha de mandioca & $640 \$ 000$ \\
\hline Hamburgo & Ferro em obras e óleo de linhaça & $367 \$ 080$ \\
\hline
\end{tabular}

FONTE: Daniel Pedro Müller. Ensaio d'um quadro estatístico da Província de São Paulo: ordenado pelas leis municipais de 11 de abril de 1836 e 10 de março de 1837. 3. ed. Edição fac-similar. São Paulo: Governo do Estado, 1978, p. 227. A estrutura da tabela com os valores em ordem decrescente tem como objetivo a melhor visualização das considerações apontadas. [Grifo nosso].

Os dados sobre a importação do porto de Santos no ano comercial de 1836-1837 foram coletados e apresentados pelo Marechal Daniel Pedro Müller ${ }^{119}$, que segundo Maria Lucília Viveiros Araújo "era engenheiro, alocado em São Paulo como ajudante de ordens

\footnotetext{
119 Segundo Airton José Cavenaghi, foi o marechal Müller quem elaborou o primeiro mapa oficial da Província de São Paulo intitulado "Mappa corographico da Provincia de S. Paulo (1837)", e sobre o material cartográfico produzido por ele aponta que "o governo provincial patrocinou sua edição na França, além de distribuí-lo para várias partes da província. Era a primeira tentativa de exposição direta dos poderes administrativos do governo provincial aos habitantes do território e nota-se que foi uma exposição mais 'visual' do que textual e normativa". Ainda de acordo com o autor, com base em Affonso Taunay, este material está relacionado "ao momento em que o território passa a ter caminhos padronizados, linhas férreas, entre outros melhoramentos que exigiram seu conhecimento pormenorizado. Esse período, entre os séculos XVII e XIX, é caracterizado por uma grande produção documental, com observações in loco do território, feitas por engenheiros, cientistas e viajantes". Airton José Cavenaghi. O território paulista na iconografia oitocentista: mapas, desenhos e fotografias. Análise de uma herança cotidiana. Anais do Museu Paulista: História e Cultura Material..., op. cit., p. 21 e 3.
} 
do governo Franca e Horta. Foi responsável por várias obras de engenharia e topografia da cidade, como a antiga Ponte do Carmo, o Chafariz do Piques e o mapeamento da província de São Paulo, mas ficou conhecido como organizador do recenseamento da província em 1836. Esse recenseamento foi o mais completo e extenso da fase histórica dos recenseamentos de São Paulo. Muller publicou seu quadro estatístico em 1838" 120.

Quanto ao território paulista visitado por Mawe entre 1807 e 1808, Pink em 1823 e Kidder no ano de 1839, ele compreendia, em linhas gerais, o seu atual limite mais o Paraná. Os viajantes Mawe e Kidder apesar de citarem dados sobre a região paranaense o fazem com base em informações de terceiros, não tendo percorrido o local. Pink não esteve no Paraná e tampouco o aborda em seu relato.

A lei $\mathrm{n}^{\mathrm{o}} 704$, de 29 de agosto de 1853, tornou o Paraná uma província independente da de São Paulo. Para melhor identificar o território paulista, com base no "Mapa do Império do Brazil (1868)", produzido por Candido Mendes ${ }^{121}$, elaboramos a seguir o mapa do Império com as suas demarcações, representadas em vermelho, até o ano de 1853, e no anexo I é possível visualizar a perda de terras pela Capitania e Província de São Paulo de 1700 a meados do século XIX, quando foi elaborada a lei.

Sobre sua viagem ao Brasil e a São Paulo Kidder escreveu Reminiscências de viagens e permanências nas Províncias do Sul do Brasil (1845). O viajante Mawe também o fez na sua obra Viagens ao interior do Brasil (1812), e Pink relatou-a no seu Diário de uma viagem feita do Rio de Janeiro no ano de 1823, em companhia de F.F. através de uma parte da província de São Paulo (1823-2000). O próximo sub-capítulo tem como foco estes relatos.

\footnotetext{
${ }^{120}$ Maria Lucília Viveiros Araújo. Os caminhos da riqueza dos paulistanos na Primeira Metade do Oitocentos..., op. cit., p. 41-42.

${ }^{121}$ Candido Mendes. Atlas do Império do Brazil (1868). Rio de Janeiro: Arte \& História, Livros e Edições, 2000, mapa II: “Mapa do Império do Brazil (1868)".
} 


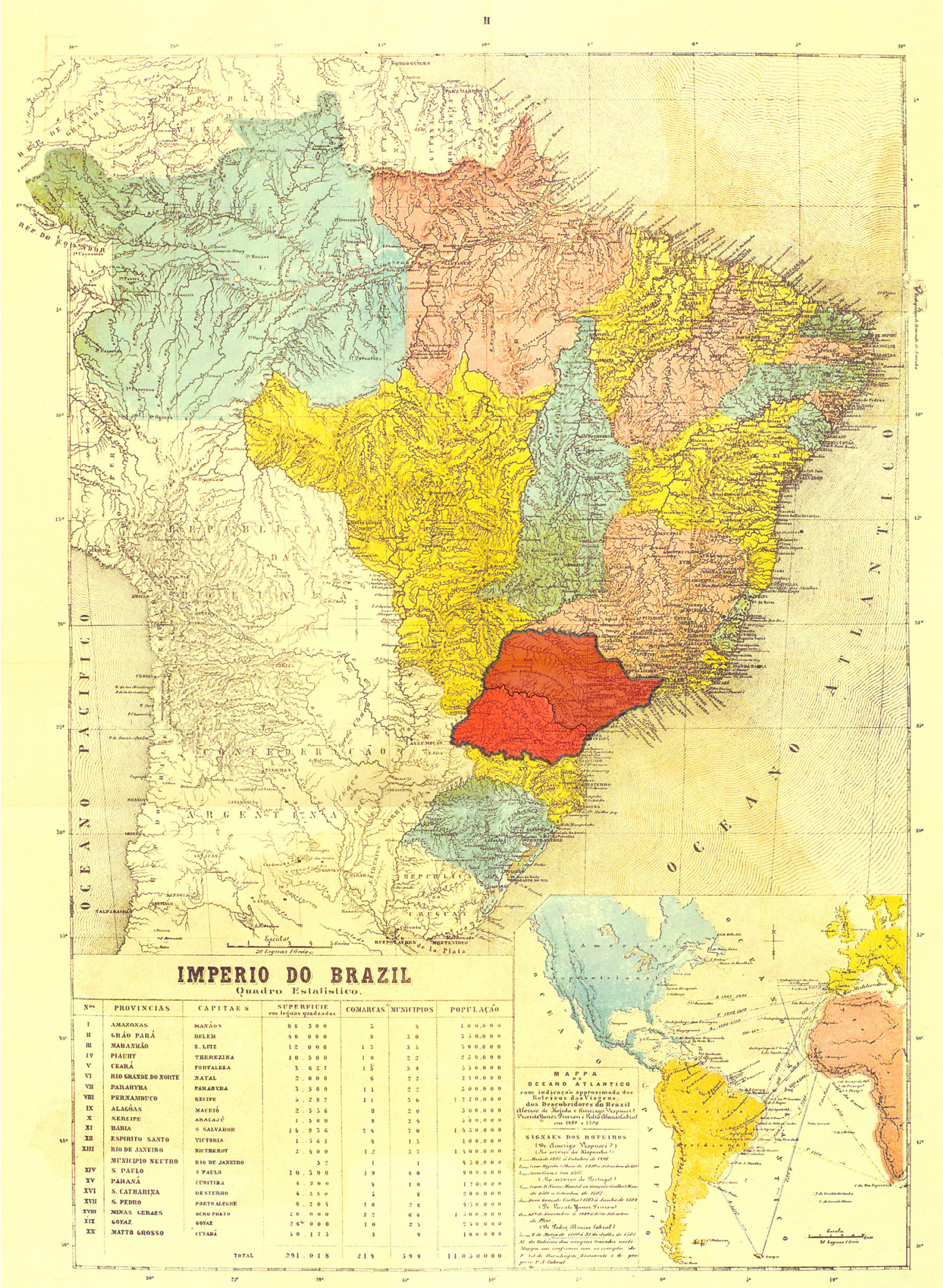




\subsection{O porto de Santos recebe os viajantes}

Ao desembarcarem no Brasil, Mawe, Pink e Kidder iniciaram um percurso de viagem que abrangeu São Paulo. O porto e a cidade de Santos foi a primeira localidade visitada e descrita por eles.

Em outubro de 1807, Mawe, vindo de Santa Catarina, desembarcou no porto de Santos $^{122}$. Em sua descrição da localidade notamos que o foco é a apresentação das capacidades portuárias, com dados sobre sua navegabilidade e segurança para as embarcações:

"Próximo de Santos vimos vários rochedos altaneiros, chamados Alcatrases [sic], e recifes contra os quais o mar arrebentava furiosamente. $\mathrm{O}$ continente é tão elevado e montanhoso que as terras baixas, na sua base, são quase imperceptíveis das elevações. O porto de Santos possui uma estrada segura e está bem protegida; é um estreito, tendo a Ilha de São Vicente à esquerda, numa extensão de meia milha, quando muda de direção. Aqui fica situado o porto, que tem bom ancoradouro, com regular profundidade, em direção à praia, que se vai tornando, pouco a pouco, mais rasa. As correntes e as ressacas trazem algum embaraço, e o planalto ocasiona bruscas variações dos ventos, atordoando os marinheiros, quando penetram nos estreitos; mas como a profundidade é pouca e as correntes fracas, o navio está a salvo, uma vez lançada a âncora, e, por meio de um bote e de um cabo de reboque, obedece perfeitamente ao comando do piloto. A parte denominada estreito está defendida por dois fortes" ${ }^{\text {"123 }}$.

De acordo com as informações obtidas por ele, dali era enviada aos territórios espanhóis e ao Rio Grande do Sul grande quantidade de açúcar, café, aguardente, arroz, mandioca, índigo, etc. E deles recebia peles e banhas, mormente reexportados para a Europa. Sérgio Buarque de Holanda destaca o açúcar como o produto de maior importância no comércio paulista no período da viagem do inglês e sobre os outros gêneros escreve:

\footnotetext{
${ }^{122}$ A comarca de Curitiba somente com a lei de $\mathrm{n}^{\mathrm{o}} 704$, de 29 de agosto de 1853 , foi elevada à categoria de Província, com o nome de Província do Paraná. Tendo em vista que antes deste ano Curitiba estava subordinada à Província de São Paulo, a primeira localidade paulista visitada por John Mawe foram as terras curitibanas, mas para o presente estudo não foi analisada sua passagem por esta região, porque as informações apresentadas foram coletadas por ele de terceiros e não apreendidas e vivenciadas pessoalmente. Conforme Sérgio Buarque de Holanda: "É a partir da comarca, e mais precisamente da própria vila de Curitiba, que principia John Mawe sua descrição da terra paulista. Serve-se neste ponto, é certo, de informações alheias, colhidas segundo parece no porto catarinense de São Francisco". Sérgio Buarque de Holanda. São Paulo. In.: Sérgio Buarque de Holanda (org.). História Geral da Civilização Brasileira. O Brasil Monárquico. Dispersão e unidade. 6. ed. Rio de Janeiro: Bertrand Brasil, 1995, tomo II, vol. 2, p. 416.

123 John Mawe. Viagens ao interior do Brasil..., op. cit., p. 58-59.
} 


\begin{abstract}
"Os outros artigos, que figuram com algum realce nessas exportações sem contar o gado, que saindo pela via terrestre não é geralmente computado - são, em ordem decrescente, couros, arroz, café, tabaco e algodão. É de notar que o algodão, tendo ocupado em 1801 o segundo lugar, logo depois do açúcar, com 160 arrobas, no valor de 640\$000, decai em 1806 (faltam os números de 1807 ou não houve exportação a consignar) para 20 arrobas no valor de $102 \$ 400$. A farinha de trigo só aparece em 1807: 594 alqueires avaliados em 816\$000. A diminuição de volume nas remessas de açúcar durante os dois últimos anos é em parte compensada com uma ascensão quase vertical nas exportações de couros e arroz, que passam respectivamente, entre 1801 e 1807 , de $298 \$ 400$ a $52: 389 \$ 480$ e de $79 \$ 500$ a $45: 618 \$ 240 " 124$.
\end{abstract}

Ao tratar da vila de Santos, Mawe mescla as informações sobre a origem, localização, salubridade, vegetação e hidrografia com sua atividade comercial, enfatizando a sua posição de rota para o desembarque e local de armazenamento da produção paulista com destino ao porto e de receptora, pois a partir dela os gêneros recebidos eram comercializados nas regiões vizinhas:

"Santos é um considerável empório comercial, serve de armazém à grande Capitania de São Paulo, é porto obrigatório da escala para os navios que comercializam com o Rio da Prata. [...] A localidade não se pode considerar, de modo nenhum, saudável, sendo baixa a região que a rodeia, coberta de matas, quase sempre alagada pelas chuvas, devido às altas montanhas das proximidades, que impedem a passagem das nuvens. Vários riachos, que correm da base dessas montanhas, cortam a região em todas as direções, confluindo para um único rio, pouco antes de chegar á cidade de Santos. Considera-se o arroz deste distrito, produzido em grandes quantidades, o melhor do Brasil, e as bananas também são conhecidas [..] Santos, sendo o porto de embarque de São Paulo, seu intercâmbio com aquela cidade é considerável. Todos os dias chegam do interior muitas mulas carregadas de mercadorias, voltando com sal, ferro, cobre, louça de barro e manufatura européias. Para o comércio com as localidades vizinhas aproveitam o transporte fluvial, pois o rio é navegável por vinte milhas, até Cubatão, onde estaciona um oficial, com uma guarda de soldados, encarregado de receber os impostos do Rei, destinados ao conserto de estradas e outras obras públicas" $" 125$.

O destaque dado à vila em decorrência do seu comércio, da ligação com o porto e das conseqüências de tal proximidade é compartilhado pelo norte-americano Daniel Parish Kidder, que esteve na região em duas ocasiões: a primeira ao chegar à Província de São Paulo, e a outra quando deixou as terras paulistas e embarcou no "Paquete do Norte" com destino ao Rio de Janeiro, ambas em 1839. Para ele: "Santos distingue-se mais pelo seu

\footnotetext{
${ }^{124}$ Sérgio Buarque de Holanda. São Paulo. In.: Sérgio Buarque de Holanda (org.). História Geral da Civilização Brasileira: O Brasil Monárquico. Dispersão e unidade..., op. cit., p. 420.

${ }^{125}$ John Mawe. Viagens ao interior do Brasil..., op. cit., p. 59.
} 
comércio, como porto de mar da província que pela beleza de sua situação ou pela elegância de seus prédios" estabelecimento dessa espécie que vimos no Brasil"127, e sobre sua produção diz: "Da grande quantidade de açúcar produzida no país, a maior parte é consumida ou exportada no mesmo estado em que sai do engenho. Muito dele, entretanto, é alvejado, conquanto sempre em forma de pó ${ }^{\prime \prime 28}$.

$\mathrm{O}$ porto e a cidade de Santos durante o século XIX teve no que concerne à São Paulo uma relação de forças centrípeta e centrífuga. Concomitantemente ao fato de ser um dos portos paulista com maior destaque por realizar o escoamento da sua produção, em grande parte centralizando tal atividade, para outras localidades da colônia portuguesa e as vizinhas espanholas, recebia produtos vindos destas e outras regiões que eram comercializados em todo território da colônia.

Segundo Denise de Moura "O intercâmbio Santos-planalto e vice-versa, marcou a sociedade do núcleo urbano e a própria capitania desde a última década do Dezoito. A todo momento negociantes saíam de Santos e chegavam à cidade incumbidos de vender algum produto, comestivel ou de uso doméstico e de trabalho. N'outras ocasiões, pegando cargas para conduzir para Santos, esses tropeiros ou seus trabalhadores apertavam-se em litígios de sedução de jovens com mães e pais vizinhos aos ranchos em que provisoriamente se estabeleciam ${ }^{, 129}$.

Grande parte da produção paulista de Santos para São Paulo, e vice-versa, era transportada no lombo de mulas como afirma Mawe. Kidder também trata deste ponto ao se deparar com as tropas enquanto seguia no caminho da baixada santista para a cidade de São Paulo:

\footnotetext{
"As tropas com que freqüentemente cruzávamos nesse caminho, ofereciam aspecto interessante. Eram compostas de cem a trezentas mulas cada uma e levavam número suficiente de homens para lidar com os cargueiros e guardá-los. Os burros geralmente levavam apenas uma cangalha com dois jacás perfeitamente balanceados, contendo sacos de açúcar ou de outra carga qualquer. Um dos animais é adestrado para conduzir os demais. Esse, que é geralmente escolhido pela sua prática e conhecimento dos caminhos, além de outras qualidades, - leva em geral um penacho na cabeça, fantasiosamente ornamentado de conchas marinhas, fitas e penas de pavão. Leva ainda um sincerro pendurado ao

${ }^{126}$ Daniel Parish Kidder. Reminiscências de viagens..., op. cit., p. 272-273.

${ }^{127}$ Ibidem, p. 276.

${ }^{128}$ Ibidem.

${ }^{129}$ Denise Aparecida Soares de Moura. Economia, cultura e sociedade em São Paulo (1808- 1850)..., op. cit., p. 33 .
} 
pescoço e caminha sempre à frente dos outros. O tropeiro chefe vai sempre muito bem montado e leva um laço preso à cincha, pronto para ser arremessado sobre qualquer animal que desgarre" $" 130$.

O inglês Edmund Pink quando se estabeleceu pela segunda vez na cidade de São Paulo, em 27 de julho [1823], registrou a hegemonia do transporte de mercadorias no lombo de mulas e nas estradas que percorreu, onde somente as tropas tinham passagem, impedindo outras formas de carregamento ${ }^{131}$ : “As estradas geralmente necessitam de melhorias para permitirem a passagem de carroças. Atualmente, a totalidade da produção é transportada no lombo de mulas; em muitos lugares só são encontradas trilhas de mulas em vez de estradas abertas ${ }^{, 132}$.

A figura do tropeiro paulista foi retratada pelos viajantes Henry Chamberlain cônsul inglês no Rio de Janeiro de 1815 a 1829 -, e Jean Baptiste Debret, que chegou ao Brasil em 1816 integrando a Missão Artística Francesa. Ambas imagens foram produzidas na década de 1820 .

\footnotetext{
${ }^{130}$ Daniel Parish Kidder. Reminiscências de viagem..., op. cit., p. 199-200.

${ }^{131}$ Francisco Luna e Herbert Klein remontam ao século XVIII a configuração dos caminhos e das estradas onde só comportava a passagem de tropas, e também destacam a importância dos muares na geração de riqueza para a Capitania de São Paulo. Como apontam: “A localização privilegiada de São Paulo garantia-lhe uma posição de monopólio como principal fornecedora para Minas Gerais e Rio de Janeiro de animais criados no Sul, principalmente mulas. No século XVIII, os muares eram os principais animais de tração na porção sul e central da Colônia, e os principais animais de carga nas trilhas da região. Pouquíssimas estradas do Brasil podiam suportar o tráfego de carros ou carretas, e com o fim da escravidão indígena todas as mercadorias passaram a seguir em lombo de mula. Esses animais eram criados nos pampas, no extremo sul da Colônia, e levados para o norte até a cidade paulista de Sorocaba, para serem vendidos a comerciantes vindos do Rio de Janeiro e Minas Gerais. Provavelmente parte expressiva da riqueza produzida na capitania no período inicial do século XIX proveio dessa atividade mercantil". Francisco Vidal Luna e Herbert S. Klein. Evolução da sociedade e economia escravista de São Paulo..., op. cit., p. 44.

${ }^{132}$ Edmund Pink. A São Paulo de Edmund Pink..., op. cit., p. 95.
} 


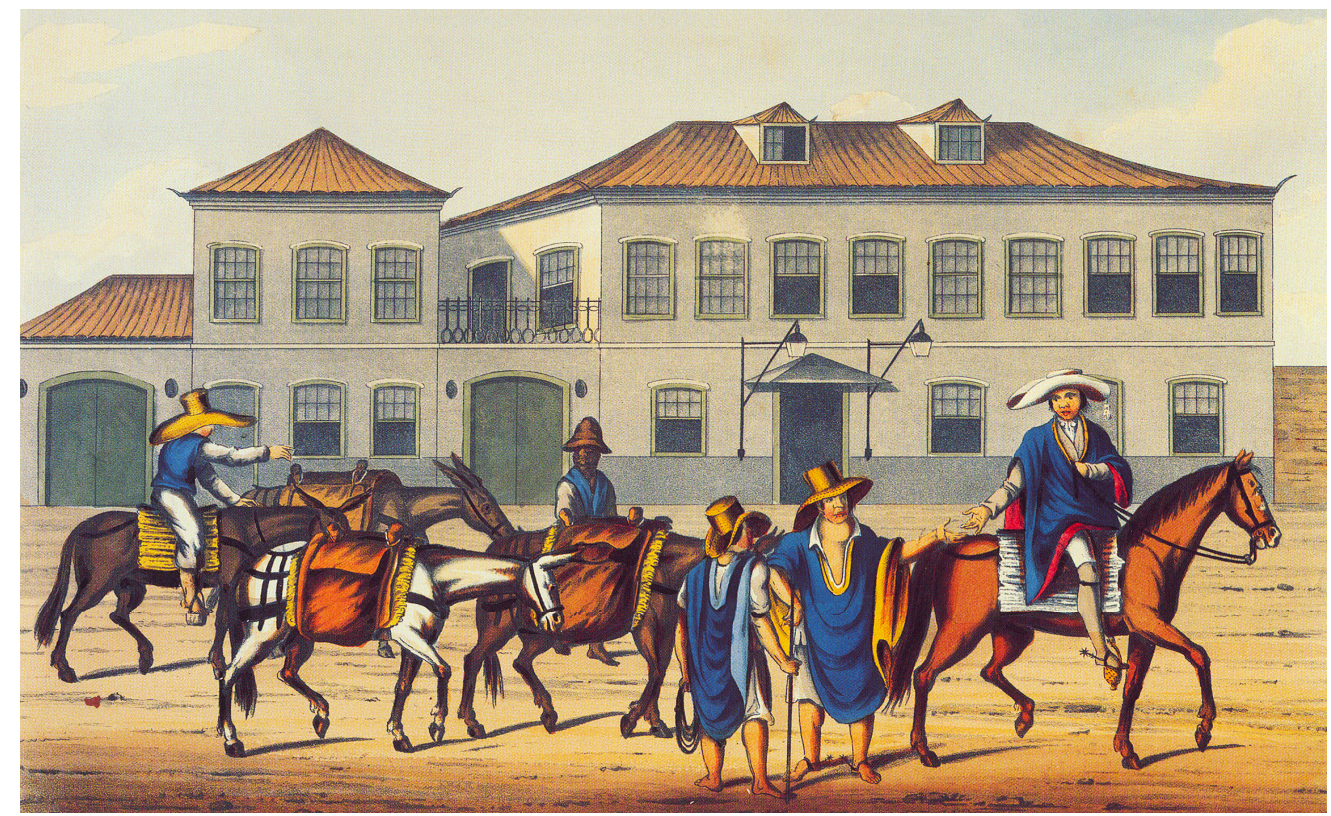

Figura 13. Henry Chamberlain. “Troperos or Muleteers”, 1822 (Tropeiros ou Arrieiros). Gravura em águatinta, 20,2 x $28 \mathrm{~cm}$. Coleção Beatriz e Mário Pimenta Camargo, São Paulo, Brasil. Ilustração do livro de Henry Chamberlain Views and Costumes of the City and Neighbourhood of Rio de Janeiro. Londres: Howlet \& Brimmer, 1822. In.: Pedro Corrêa do Lago. Iconografia paulistana: do século XIX. 2. ed. rev. e ampl. São Paulo: Capivara, 2003, p. 42.

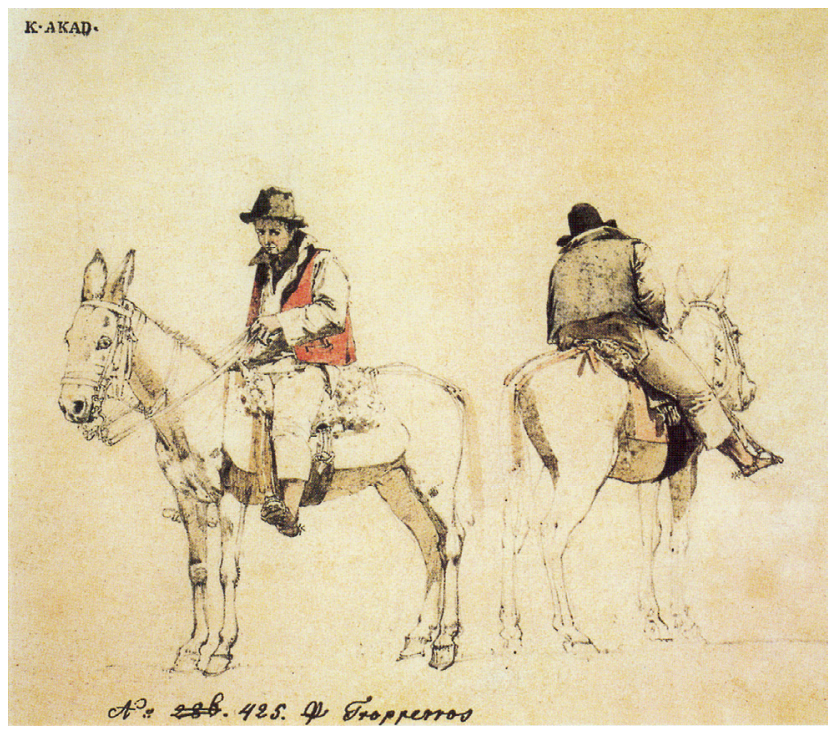

Figura 14. Jean-Baptiste Debret. "Pauvres Tropeiros de St. Paul, 1823" (Pobres tropeiros de São Paulo). Aquarela, 15,2 x 22,4 cm. Museus Castro Maya - IPHAN/MinC, Rio de Janeiro, Brasil. In.: Pedro Corrêa do Lago. Iconografia paulistana: do século XIX. 2. ed. rev. e ampl. São Paulo: Capivara, 2003, p. 89.

Em 30 de maio de 1823 Pink desembarcou no porto de Santos para visitar os distritos açucareiros paulistas. Sua descrição, tal como a de Mawe anos antes, versa principalmente sobre a capacidade, a movimentação portuária e os gêneros comercializados: 
"O porto tem grande capacidade. Navios com tonelagem de 17 pés podem ancorar longe da cidade e receber suas cargas a bordo e embarcações menores são carregadas ao longo dos cais. Sendo ele o porto melhor localizado nesta província, domina uma grande quantidade do comércio tanto de exportação como de importação. Seu comércio de exportação, até poucos anos atrás, se limitava à capital do Brasil e às províncias do Sul e do Norte, sendo o porto o último lugar para a troca de vinhos e outras mercadorias trazidas dali. Mas agora grandes quantidades de açúcar são embarcadas diretamente para várias partes do continente europeu. Desfruta também de insignificante comércio de escravos com a costa da África. O sal deve ser enumerado como o principal artigo entre as importações para esta província. Ele é indispensável para o gado das províncias locais" ${ }^{\text {"133. }}$.

$\mathrm{Na}$ vila de Santos apresentou seu passaporte ao governador e, quando trata desta localidade descreve sucintamente sua fundação, localização e estabelecimentos:

\begin{abstract}
"Santos - situa-se na latitude 24.15 Sul e na longitude 16.30 Oeste, cerca de 190 milhas ao Sudeste do Rio... uma cidade considerável, mal construída, mas muito vantajosamente localizada no lado norte da Ilha de São Vicente. Foi fundada no ano de 1545. Possui uma casa de misericórdia, a mais antiga do Brasil, vários conventos e hospitais, várias capelas e uma igreja matriz [...] Santos está sujeita a chuvas quase contínuas, estando situada tão perto da serra de Cubatão" ${ }^{\text {"134 }}$.
\end{abstract}

Nas descrições feitas pelos viajantes o destaque é dado ao comércio, no papel desempenhado pelo núcleo santista nas relações comerciais com o planalto, e na situação privilegiada de rota de transporte e escoamento da produção paulista. Ao visitar o porto seus olhares voltaram-se para o mapeamento da sua localização, capacidade, movimentação e navegabilidade. A ênfase está na ação humana e suas possibilidades, seja no comércio ou nas atividades portuárias.

Após visitarem as terras santistas, os viajantes seguiram viagem para a cidade de São Paulo através de Cubatão. O objetivo do próximo sub-capítulo é descrever como a ótica econômica utilitarista se faz presente nos seus apontamentos sobre as regiões percorridas.

\footnotetext{
${ }^{133}$ Edmund Pink. A São Paulo de Edmund Pink..., op. cit., p. 82.

${ }^{134}$ Ibidem.
} 


\title{
2.2. A visita à cidade de São Paulo
}

John Mawe quando desembarcou em Santos obteve a permissão do governador para ficar na vila. Munido de uma carta de recomendação, procurou um local para dormir, todavia não o encontrando decidiu seguir para a cidade de São Paulo, via Cubatão. Os melhoramentos no caminho para a passagem de transeuntes é valorizada pelo inglês como reflexo do espírito empreendedor do brasileiro, que ultrapassa os limites e as dificuldades impostas pela natureza. Para ele, o destaque de uma obra arrojada e seu sucesso é proporcional à capacidade do homem em utilizar ferramentas capazes de sobrepor e domesticar os obstáculos naturais de acordo com suas necessidades. Sobre o caminho escreve:

\begin{abstract}
"Os milhões de coroas despendidos em derrubar as matas, perfurar as rochas por distâncias consideráveis, assim como pavimentá-las, de um lado, em toda a extensão, dão não pequena idéia do espírito empreendedor dos brasileiros. Poucas obras públicas, mesmo na Europa, lhes são superiores e, se considerarmos que a região por onde passa é quase desabitada, encarecendo, portanto, muito mais, o trabalho, não encontremos nenhuma, em país algum, tão perfeita, tendo em vista tais desvantagens" ${ }^{\prime 135}$.
\end{abstract}

Após percorrer o caminho de Cubatão, chegou à São Paulo e o aspecto da cidade lhe agradou. As ruas eram limpas e pavimentadas, as vias principais possuíam casas de dois a três andares e eram pintadas em várias cores. As construções eram erguidas com taipa e os telhados moldados para evitar a umidade ${ }^{136}$. Havia suntuosas procissões religiosas e no carnaval brincava-se de jogar frutas de cera com água perfumada. Sobre os habitantes, trata dos homens, seus trajes e o grau de civilidade - considerando-o bastante adiantado. Com relação às mulheres aborda seu comportamento, afazeres domésticos e sobre seu vestuário, além das informações escritas, há a gravura em cobre Costume delle Pauliste (Traje das Paulistas), impressa pela primeira vez na edição italiana (1817) ${ }^{137}$.

Havia em abundância perus, gansos e patos. As plantas alimentícias, leguminosas e frutas eram bastante variadas e em grande quantidade. Segundo o viajante, "a fertilidade da região que circunda São Paulo pode ser avaliada pela quantidade de produtos com os quais, como afirmei, abarrotam o mercado"138.

\footnotetext{
${ }^{135}$ John Mawe. Viagens ao interior do Brasil..., op. cit., p. 61.

${ }^{136}$ Ibidem, p. 62-65.

${ }^{137}$ Ibidem, p. 72-73. Sobre a imagem Traje das Paulistas ver Capítulo 1.

${ }^{138}$ Ibidem, p. 66.
} 
Dentre as atividades desenvolvidas pelos habitantes de São Paulo, nos apresenta a pouca existência de médicos e o grande número de boticários, alguns ourives, alfaiates, sapateiros, marceneiros e diz que a grande maioria da população vive do cultivo de pequenas porções de terras, como fazendeiros ou modestos lavradores. O destaque vai para os comerciantes porque "constituem classe numerosa, que, como na maioria das cidades coloniais negociam com quase tudo e, muitas vezes fazem fortunas consideráveis "139.

Ao tratar das florestas paulistas é sintomático o filtro econômico e das possibilidades de lucro com a exploração dos recursos naturais. Sobre os animais destaca juntamente com a grande diversidade a qualidade de sua pelagem. Quando apresenta a madeira descreve suas lindas flores, aromas, propriedades medicinais, mas, também acrescenta a possibilidade de extração e uso pelo homem, no caso, por ser apropriada para a construção. A descrição da ocorrência da madeira em São Paulo é associada ao seu valor intrínseco de lucro:

"As florestas encerram grande variedade de animais da espécie do macaco, e também animais de presa, alguns dos quais possuem peles razoavelmente boas. Entre eles, inclui-se uma espécie peculiar de lontra. Os insetos são numerosos, mas os mosquitos não atacam tanto quanto os do Rio da Prata. O animalzinho denominado ninguá ou bicho do pé é aborrecido; introduz-se sob as unhas dos dedos dos pés e, às vezes, das mãos, mas pode ser eliminado facilmente, extraindo-se-o [sic], e ao seu saco de ovos, com uma agulha, enchendo-se a cavidade com cloreto de mercúrio, ou tabaco, pelo receio de que ainda reste algum. Répteis, como já disse, encontram-se em grande quantidade, mas vi poucos, exceto sapos, que, à noite, coaxam nas estradas e, muitas vezes, infestam as ruas da cidade. A surucucu e a jararaca (serpentes), segundo se afirma são muito perigosas. As florestas possuem madeira durável, em quantidade, apropriada para construções. Das árvores que conservam os nomes indígenas, algumas dão ótima goma. $\mathrm{O}$ jacarandá, conhecido na Inglaterra como pau rosa, é bastante comum. Muitos dos seus arbustos cobrem-se de lindas flores, extremamente aromáticas. Entre as inúmeras trepadeiras, que cobrem o solo das terras incultas, algumas passam por ser antídotos infalíveis contra a picada de répteis venenosos; uma, em particular, o Coração de Jesus, é universalmente conhecida" ${ }^{\text {140 }}$.

\footnotetext{
${ }^{139}$ John Mawe. Viagens ao interior do Brasil..., op. cit., p. 64-65.

"É inquestionável que a agricultura foi a principal força propulsora da economia e sociedade paulista nos séculos XVIII e XIX. Ainda assim, não foi essa a única área de atividade existente. Uma significativa minoria da população não se dedicava à lide agrícola, e essa minoria aumentou no decorrer do tempo, conforme a economia e a sociedade foram se tornando mais complexa e mais urbanas. Mas esse grupo era complexo, abrangendo alguns elementos muito abastados, de profissionais liberais e comerciantes com negócios internacionais a tropeiros com grandes tropas de mulas e escravos. Essa parte da elite não-agrícola provavelmente tinha laços familiares e financeiros com a elite dos proprietários de terras e formava, juntamente com os agricultores mais ricos, os produtores de açúcar e café, a classe dominante da sociedade provincial". Francisco Vidal Luna e Herbert S. Klein. Evolução da sociedade e economia escravista de São Paulo..., op. cit., p. 239.

140 John Mawe. Viagens ao interior do Brasil..., op. cit., p. 68.
} 
Pink, quinze anos após Mawe, fez o mesmo trajeto. Ao chegar a Cubatão obteve algumas mulas para ele e sua carga e seguiu viagem para a cidade de São Paulo, "e logo começamos a subir a imponente serra de Cubatão. A estrada serpenteava em ziguezague até o topo... calçada, o que a torna transitável em qualquer tempo. Levamos duas horas para completar nossa tarefa". ${ }^{141}$. Após percorrer 44 milhas, chega à cidade às 22:00 do dia 7 de junho de 1823. Sua descrição abrange a população, as construções, as ruas, as casas, as pontes e sua localização como entroncamento das estradas provenientes dos distritos açucareiros, o que proporcionava vida aos negócios:

"A cidade de São Paulo é de tamanho considerável, muito irregularmente construída. Atualmente, a população deve ser de mais ou menos 20.000 habitantes, incluindo escravos... bem situada, em terreno suavemente elevado, na confluência de dois pequenos rios banhando-a nos lados leste e oeste. O Rio Tietê a atravessa a cerca de - légua ao norte, ele corre muito perto do Trópico de Capricórnio. As casas são geralmente feitas de taipa. Possui uma casa de misericórdia, diversos hospitais, conventos, igrejas, uma catedral, também é residência do bispo - que tem um palácio dentro da cidade e outro a poucas milhas de distância -, uma prisão, banco, teatro, etc., além de uma casa para o teste de ouro que agora é pouco requisitada, uma vez que não há minas em funcionamento na vizinhança embora a [situação] anteriormente considerável como a primeira mina de ouro explorada no Brasil esteja situada a poucas léguas da cidade. Há varias pontes de pedra e outras de madeira. Há diversos chafarizes, mas a melhor água vem do rio. Muitas das ruas são bem calçadas. As casas das pessoas mais abastadas são bem pintadas e com janelas envidraçadas, mas para aqueles mais pobres esses luxos ainda não foram conferidos, as janelas de rótula são as mais usadas. Também possui aqui seu palácio, o qual é necessário visitar quando se chega para exibir o passaporte e apresentar os cumprimentos. $\mathrm{O}$ fato de todas as estradas provenientes dos vários distritos açucareiros se encontrarem aqui torna o palácio extremamente agitado e dá vida aos seus negócios, particularmente durante a temporada em que as maiores quantidades de açúcar são transportadas para o embarque do Porto de Santos. Em outras temporadas é parado. Mais do que em qualquer outro dia, a maior quantidade de negócios é feita no domingo, quando o povo, geralmente vindo do campo, se reúne na cidade" ${ }^{142}$.

A cidade de São Paulo recebeu o viajante mais uma vez em seu retorno dos distritos açucareiros, em 27 de julho [1823]. Nesta ocasião, apresenta um quadro das regiões visitadas e inicia sua ida ao Rio de Janeiro, no dia 21 de outubro do mesmo ano. Sobre a vida na cidade pintou a aquarela Sketch in the city - O Palacio de Sola (Vista da Cidade Palácio da Sola, 1823).

${ }^{141}$ Edmund Pink. A São Paulo de Edmund Pink..., op. cit., p. 83.
${ }^{142}$ Ibidem, p. 85-86. 
Segundo Pedro Corrêa do Lago “com esta extraordinária aquarela Pink torna-se o primeiro artista estrangeiro a mostrar uma cena urbana de São Paulo em cores, desligada da representação específica de qualquer monumento. Este Palácio da Sola encontrava-se no Largo da Misericórdia, e vê-se claramente o chafariz realizado pelo Mulato Tebas, o mais famoso artesão do século XVIII. As mercadorias expostas nas portas da bela casa na Rua da Candelária (como indica uma placa abaixo da primeira janela), depois Rua do Comércio [...] Também única é a cena da jovem à janela, com o crucifixo, a vestimenta e o recato exigido das mulheres na São Paulo da época" ${ }^{\text {"143. }}$

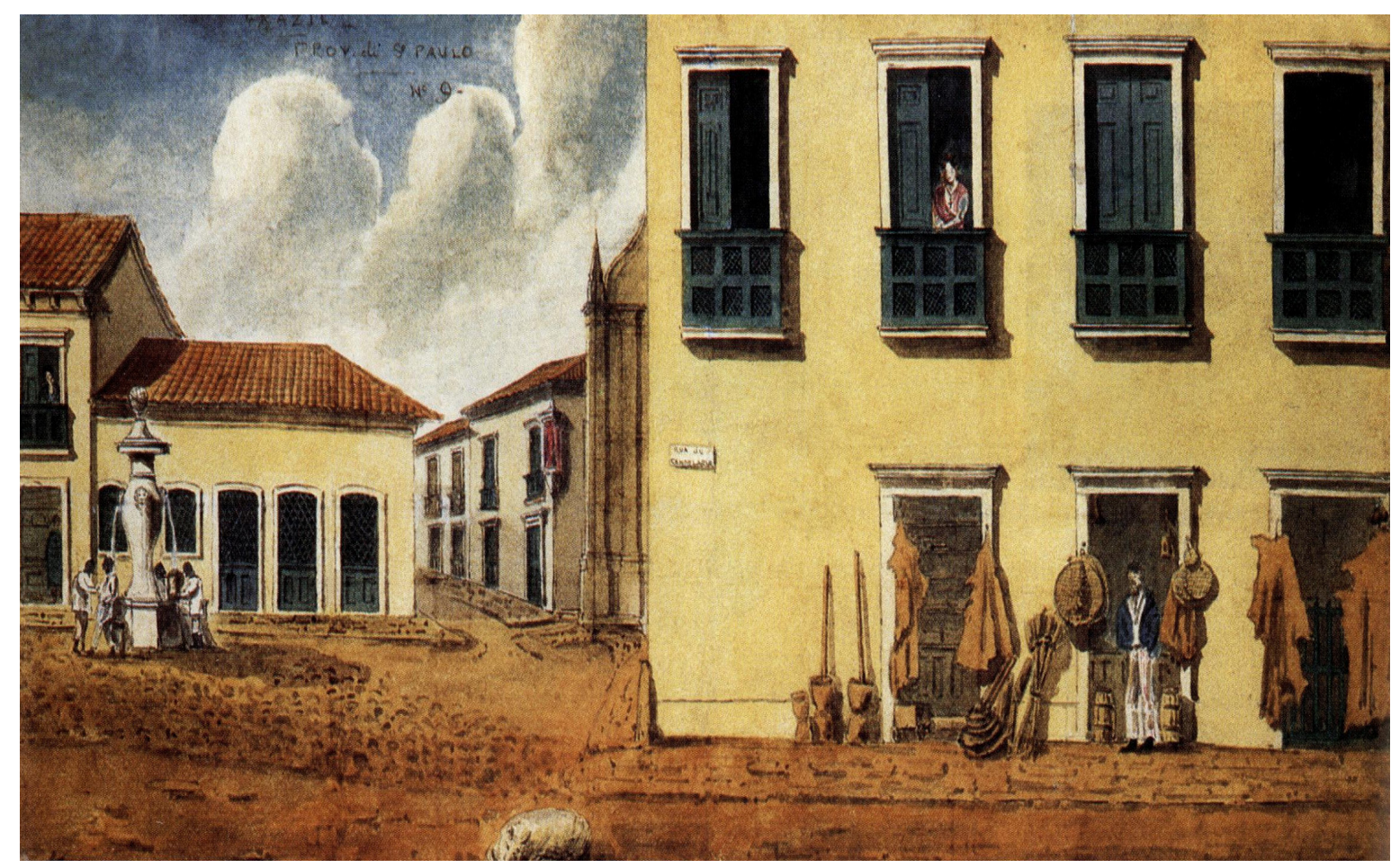

Figura 15. Edmund Pink. "Sketch in the city - O Palacio de Sola (Vista da Cidade - Palácio da Sola)", 1823. Aquarela, 18,5 x $40 \mathrm{~cm}$. Acervo de Artes da BOVESPA, São Paulo, Brasil. In.: Pedro Corrêa do Lago. Iconografia paulistana: do século XIX. 2. ed. rev. e ampl. São Paulo: Capivara, 2003, p. 62.

Daniel Kidder, em 1839, como os outros viajantes antes dele, passou pelo caminho de Cubatão seguindo para São Paulo. Sobre a estrada considera-a uma importante obra e "uma das mais caras estradas que já se construiu no Brasil. Entretanto, devido à sua enorme declividade não pode ser transitada por veículos. Compreende cerca de quatro milhas de sólida pavimentação e mais de cento e oitenta curvas em todo o seu sinuoso

143 Pedro Corrêa do Lago. Iconografia paulistana: do século XIX. 2. ed. rev. e ampliada. São Paulo: Capivara, 2003, p. 62. 
percurso. A conclusão dessa importante obra mereceu ser comemorada como acontecimento notável na história colonial portuguesa"144. Entretanto, devido ao fluxo intenso ela apresentava sinais de deterioração e alguns perigos para quem transitasse por ela $^{145}$.

Na cidade descreve sua localização, os passeios, os edifícios, as casas, o arranjo interno das moradias, os subúrbios e o Jardim Botânico. No domingo, um dia pós ter chegado com sua esposa, visitaram diversas igrejas, capelas de conventos e, no dia 25 de janeiro, a procissão e as festas da conversão de São Paulo, padroeiro da cidade e da província.

Na mesma época da visita de Kidder à província, a paisagem vista do Caminho de Santos para São Paulo foi registrada pelo naturalista francês Noel-Aimé Pissis, em julho de 1839, na aquarela reproduzida abaixo.

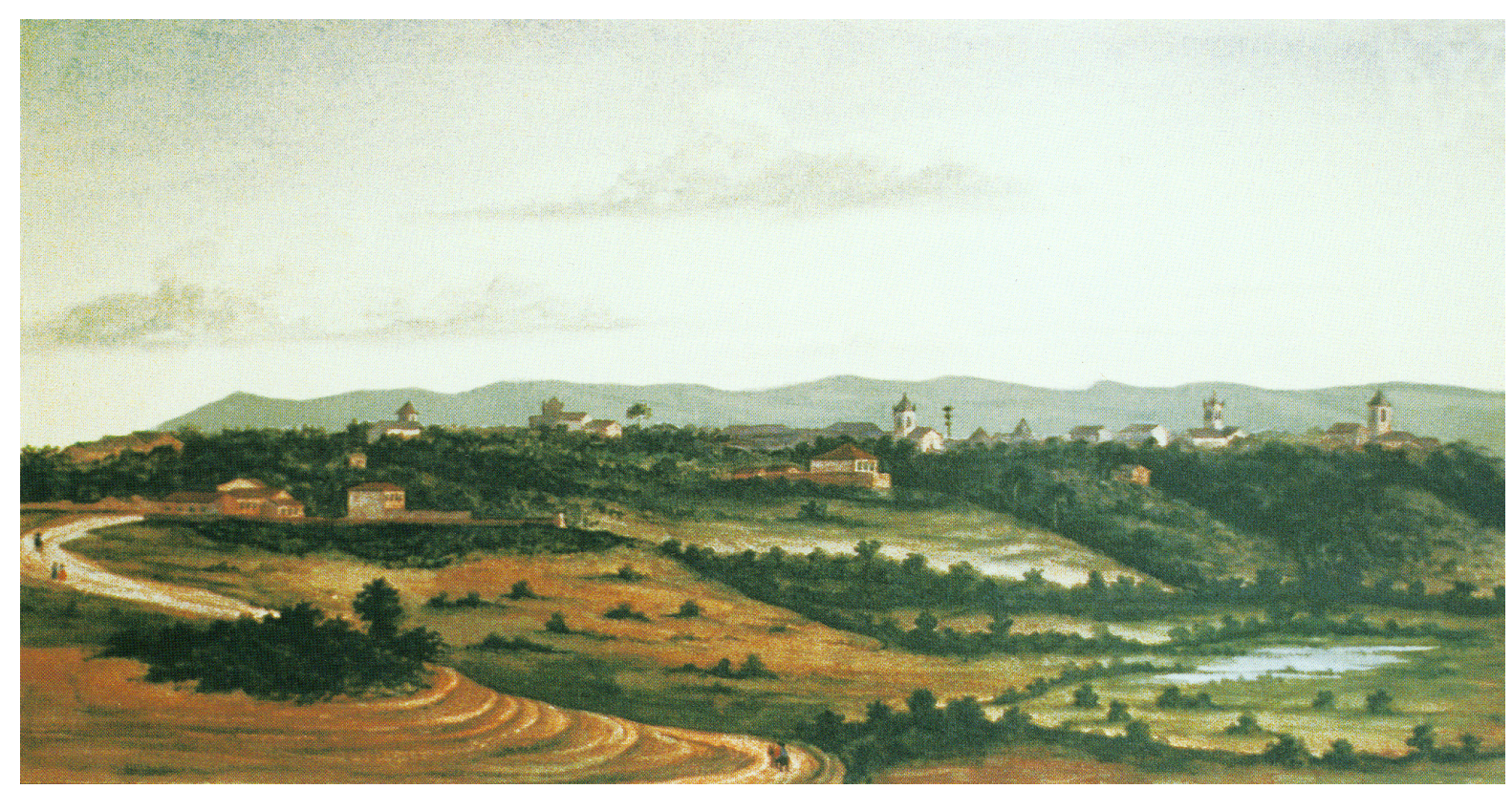

Figura 16. Noel-Aimé Pissis. "São Paulo - Vista tomada do Caminho de Santos", 1839. Aquarela, 16, 5 x 25,8 cm. Coleção particular, São Paulo, Brasil. In.: Pedro Corrêa do Lago. Iconografia paulistana: do século $X I X$. 2. ed. rev. e ampl. São Paulo: Capivara, 2003, p. 119.

\footnotetext{
${ }_{144}^{144}$ Daniel Parish Kidder. Reminiscências de viagem..., op. cit., p. 191.

145 "O contínuo perpassar dos animais e das enxurradas que de todas as direções se precipitam sobre a estrada, por ocasião das grandes chuvas, tornaram imprescindível a pavimentação dessa passagem da serra. A despeito da perfeição original do trabalho, continuadamente conservado e reparado, encontramos diversas valetas cavadas pela erosão e barreiras que se poderiam chamar colossais [...] Nesses pontos, um único passo em falso, precipitaria no vácuo a montaria e o cavaleiro, sem a menor probabilidade de salvação". Ibidem, p. 192.
} 
Quando estavam percorrendo as terras paulistas Mawe, em 1808, e Kidder, em 1839, viram nas proximidades da cidade o rio Tietê e seus arredores e as minas do Jaraguá.

O primeiro a convite do então capitão-general e governador de São Paulo (Antônio José da Franca e Horta, 1802-1811) cruzou o Tietê a caminho das minas. A descrição do rio e seu entorno é feita nos seguintes termos:

"Neste ponto, é de considerável largura e mais profundo que nos arredores de São Paulo; possui excelente ponte de madeira, isenta de portagem. Nas suas margens há lugares verdadeiramente dignos de inveja; belas e ricas terras cobertas de madeira, capazes de satisfazer, se devidamente cultivadas, não somente as necessidades, mas os luxos da vida, num grau centuplicado" ${ }^{146}$.

Após se distanciarem quatro léguas da cidade chegaram às minas de Jaraguá, de propriedade do governador ${ }^{147}$. Mawe diz serem elas "afamadas pelos imensos tesouros, há aproximadamente dois séculos, quando este distrito era considerado o Peru do Brasil e, pelos portos de Santos e São Vicente, se embarcava o ouro para a Europa"148. O tema principal do relato sobre a região é o sistema de trabalho nas minas, denominado lavagem. Este processo junto à sua descrição conta com uma gravura em cobre intitulada $A$ view of the gold washing at Jaragua near Saint Pauls (Uma Vista da Lavagem do Ouro em Jaraguá, perto de São Paulo, 1812), reproduzida na página 26.

$\mathrm{Na}$ região das minas, o que viu despertou a expectativa de encontrar algum minério ou pedra de valor. Em sua obra diz:

"Despertou-me profundamente a atenção a grande quantidade de destroços ou refugos das lavagens de ouro, que jazem nos inúmeros montes e contém várias substâncias que me deram forte esperança de encontrar alguns espécimes interessantes e valiosos de turmalinas, topázios e outras cristalizações, e também uma rica série de rochas, que podiam formar o feognósticos da região. Fiquei, tão fortemente preocupado com esta esperança, que, realmente, imaginei ter em meu poder um dos melhores produtos minerais do Brasil" $" 149$.

\footnotetext{
${ }^{146}$ John Mawe. Viagens ao interior do Brasil..., op. cit., p. 69.

147 "O governador convidou-me a visitar as minas de ouro de Jaraguá, as primeiras descobertas no Brasil, que agora lhe pertencem, bem como uma fazenda vizinha, distante cerca de vinte e quatro milhas da cidade". Ibidem, p. 68-69. Segundo Maria Lucília Viveiros Araújo, "a fazenda do Jaraguá foi comprada pela viúva Gertrudes Galvão. Na fazenda havia extração de ouro. Essa propriedade pertencia ao general Franca e Horta, quando John Mawe a visitou, e apareceu, em 1802, na declaração de bens de Maria Leite Lombria". Maria Lucília Viveiros Araújo. Os caminhos da riqueza dos paulistanos na Primeira Metade do Oitocentos..., op. cit., p. 155.

${ }^{148}$ John Mawe. Viagens ao interior do Brasil..., op. cit., p. 69.

${ }^{149}$ Ibidem, p. 70.
} 
E com tais sentimentos, por três dias consecutivos, desde manhã muito cedo lavrou a terra "até que minhas mãos não suportassem mais o martelo, [e] vi-me forçado a abandonar a pesquisa, como infrutífera" ${ }^{\prime 50}$. Deixando o trabalho nas minas visitou a fazenda do governador na companhia dele e de sua esposa.

Kidder, trinta anos depois, na mesma região das minas visitou a fazenda de Dona Gertrudes $^{151}$, e nas margens do rio Tietê apresenta o cultivo do chá na propriedade do Coronel Anastácio ${ }^{152}$.

Para Kidder "entre as excursões que fizemos pelas circunvizinhanças de S. Paulo, uma das mais interessantes foi às velhas minas de ouro do Jaraguá" ${ }^{\text {"153 }}$. Por sua vez, quando esteve nestas paragens ficou hospedado em uma fazenda de Dona Gertrudes, proprietária de mais "seis outras de valor quase igual, das quais duas estavam situadas ainda mais perto da cidade sendo todas elas dotadas do competente número de escravos, cavalos, mulas, etc. $^{\prime 154}$.

Durante sua visita escalou o morro do Jaraguá na companhia do francês Sr. Guillemin e alguns de seus assistentes botânicos. Sobre a paisagem contemplada ao atingir o pico escreve:

"O panorama que daí descortinamos era de beleza e variedade indescritíveis, e, compensou-nos cem vezes o esforço da escalada. Não muito longe, do lado de trás, avistamos diversas 'lavradas', ou lugares onde lavavam ouro, que, tendo sido extensivamente utilizado em tempos remotos, deixaram o solo revolvido e nu. Na direção oposta repousa a

\footnotetext{
${ }^{150}$ John Mawe. Viagens ao interior do Brasil..., op. cit., p. 70.

151 “O brigadeiro Manuel Rodrigues Jordão faleceu em 1828, deixando viúva Gertrudes Galvão de Oliveira e Lacerda. Sua riqueza estava distribuída em $28 \%$ de escravos (281), 27\% de dívidas ativas e $17 \%$ de imóveis (17). Os outros inventários [grupo A - constituído por aqueles com monte bruto superior a 50 contos de réis] tinham a mesma proporção em imóveis e escravos. Entretanto, este negociante tinha mais escravos do que o padrão. Algumas propriedades eram em sociedade, tais como: o sítio São João de Queluz, em Itu, em sociedade com Elias Antônio Pacheco, que foi a leilão para separar a sociedade; o engenho Bonsucesso, de Constituição, em sociedade com a viúva Ana Vitória; a fazenda Serra de Santo Antônio das Palmeiras, de Bananal, em sociedade com Antônio Barbosa Dias; a fazenda Espírito Santo, de Paraibuna, em sociedade com Antônio Pereira de Barros; as terras de Salto Grande estavam com o sócio e administrador Caetano José Gomes Carneiro para iniciar a produção. Nas demais propriedades ficavam somente os administradores [...] Nessas propriedades trabalhavam os 242 escravos; elas produziam açúcar, café, laranja, algodão, arroz, feijão e milho. [...] O casal residia na Rua Santo Antônio, em frente à igreja. Era um sobrado de 3:400 contos de réis, com três lanços, cinco portas, cinco janelas com grades de ferro e quintal, onde trabalhavam vinte e quatro escravos [...]".Maria Lucília Viveiros Araújo. Os caminhos da riqueza dos paulistanos na Primeira Metade do Oitocentos..., op. cit., p. 153-154.

152 Trata-se do coronel Anastácio de Freitas Trancoso. Nascido no ano de 1753, em Paranaguá, iniciou a carreira militar no posto de capitão de uma companhia de voluntários reais de um regimento organizado por Martim Lopes Lobo de Saldanha, em 1775, para combater no Sul. Foi membro do Governo Provisório. Era pai de Francisco Pinto do Rego Freitas. O lugar onde ficava a fazenda do coronel é hoje um bairro de São Paulo, o Anastácio. Nota de Rubens Borba de Morais. In.: Daniel Parish Kidder. Reminiscências de viagem..., op. cit., p. 225.

${ }^{153}$ Daniel Parish Kidder. Reminiscências de viagem..., op. cit., p. 212.

${ }^{154}$ Ibidem.
} 
capital da província, estendida sobre a encosta antigamente denominada Campos de Piratininga. Avistavam-se também as localidades de Campinas, Itu, Sorocaba, Santo Amaro e Mogi das Cruzes. O aspecto geral da região assemelhava-se vagamente ao de algumas que visitávamos no hemisfério setentrional, e, dada a impossibilidade de distinguirmos qualquer objeto, a não ser algumas plantas à borda dos precipícios, pela primeira vez durante a nossa permanência no Brasil, poderíamos ter imaginado que avistávamos um trecho dos nossos Estados Unidos"155.

Após a excursão ao morro, Kidder passa a descrever a fazenda de Dona Gertrudes. O seu interesse no que via e presenciava resultou nas constantes anotações que fazia. Em determinada ocasião diz:

"Pedimos desculpas à Dona Gertrudes por tomarmos algumas notas em sua presença, explicando-lhe que tínhamos visto tanta coisa interessante aquele dia que desejávamos fixar algumas impressões pessoais. A senhora, porém, manifestou-se satisfeitíssima pelo interesse que demonstrávamos por tudo quanto tínhamos visto e ouvido, acrescentando que sentia prazer em ver encaminhadas para a imprensa informações lisonjeiras sobre sua propriedade agrícola. Portanto, em vista de sua autorização, passaremos em rápida revista - o que de outra forma não ousaríamos fazer - as instalações de seu estabelecimento rural" ${ }^{156}$.

Na propriedade se cultivava cana-de-açúcar, mandioca, feijão, arroz e café. Como aponta "a excursão ao Jaraguá nos proporcionou excelente oportunidade de observar a disposição das plantações do interior. Esse arranjo difere, nos vários países, segundo o clima, as culturas e o desenvolvimento da agricultura" ${ }^{157}$. O viajante enfatiza dois aspectos da fazenda: o engenho para a fabricação da cachaça e o processamento da farinha de mandioca "o principal farináceo do Brasil, e, por isso merece especial destaque"158.

A riqueza da propriedade de Dona Gertrudes está na sua capacidade de comercializar os produtos cultivados e a aguardente produzida, em decorrência e com base na estrutura presente onde "viam-se numerosas construções, tais como a senzala dos negros, armazéns para os diversos produtos e o maquinário necessário para pô-los em condições comerciáveis"

\footnotetext{
${ }^{155}$ Daniel Parish Kidder. Reminiscências de viagem..., op. cit., p. 214-215.

${ }^{156}$ Ibidem, p. 221.

${ }^{157}$ Ibidem, p. 215.

${ }^{158}$ Ibidem, p. 216.

${ }^{159}$ Ibidem, p. 215.
} 
Na volta do Jaraguá foi até à plantação de chá do Coronel Anastácio "uma das mais interessantes que visitamos" ${ }^{\prime 60}$, nas margens do Rio Tietê. Antes de escrever sobre o local, o viajante fornece um quadro da cultura do chá no Brasil com dados sobre sua introdução e a vinda de chineses para a lavoura. Na propriedade trata do cultivo, a qualidade das folhas e o seu cuidado para adquirir crescente valor comercial e a venda da produção. Acompanhando o dono caminhou pela fazenda e "depois de percorremos as proximidades da sede onde vimos belas plantações de mandioca, cana-de-açúcar, banana, café e algodão, sentamo-nos um pouco na sala de visitas do Coronel enquanto ele desenvolvia novamente alguma de suas batalhas. Foi-nos então servido vinho paulistano, puro suco de uvas cultivadas na fazenda, e que, segundo a opinião dos entendidos, era de fina qualidade $^{, 161}$.

Após a visita, seguiu para cidade e conheceu a Academia de Direito, tendo como guia o secretário da instituição e, no local foi apresentado ao presidente em exercício Dr. José Maria Brotero, casado com a norte-americana D. Izabel Dabney ${ }^{162}$. Em seu relato apresenta os prédios, as salas de aula e preleções, as capelas, as disciplinas, os requisitos para o ingresso, a estrutura do exame de argüição e do curso de Direito, e também a biblioteca onde não encontrou um exemplar da Bíblia e, para sanar a lacuna doou um exemplar da tradução portuguesa de Pereira. As características do curso associada à diminuição do número de alunos após 1829 são creditadas pelo viajante à forma como a Academia foi estruturada:

"Afim de explicar as peculiaridades do curso acima descrito é preciso que se diga que, na sua organização foi tomada como paradigma a Universidade de Coimbra. A cultura proporcionada pelo estabelecimento, poderá ser formal e exata, mas, nunca popular. Os brasileiros visam mais a utilidade que as formas antiquadas da Universidade portuguesa, como talvez se possa concluir do decréscimo que ultimamente se vem observando na freqüência da Academia [...] E, quer-nos parecer que, para que consiga ter alunos, será necessário que a Universidade de São Paulo (sic) condense e modernize o seu curso" ${ }^{163}$.

O estar associado a modelos e padrões portugueses é visto como uma das causas e sinônimo de arcaísmo e retrocesso. Para Kidder esta situação não é condizente com a posição da Academia de Direito "ou como é freqüentemente denominada, a Universidade

\footnotetext{
${ }^{160}$ Daniel Parish Kidder. Reminiscências de viagem..., op. cit., p. 227.

161 Ibidem, p. 215.

162 Filha de John B. Dabney, cônsul norte-americano. Antonia Fernanda Pacca de Almeida. Desafio americano..., op. cit., p. 165.

${ }^{163}$ Daniel Parish Kidder. Reminiscências de viagem..., op. cit., p. 232.
} 
de São Paulo (sic), [que] ocupa o primeiro lugar entre os estabelecimentos de ensino no Império"164. Após a visita à instituição de ensino e de "uma permanência suficientemente longa na cidade de São Paulo preparamo-nos para visitar o interior da província" ${ }^{\text {"65 }}$.

Kidder depois de percorrer o interior da província paulista retornou à cidade. Nesta ocasião visitou o Hospital da Misericórdia, a principal escola primária, conversou com políticos paulistas e assistiu a debates na Assembléia Provincial, onde entregou uma "Proposta apresentada à Assembléia Legislativa da Imperial Província de São Paulo" para o fornecimento gratuito pela American Bible Society de doze Bíblias traduzidas para o português pelo padre Pereira de Figueiredo às escolas primárias da Província. Com isto decidiu deixar as terras paulistas, e em Santos embarcou no vapor "Paquete do Norte" para o Rio de Janeiro.

Mawe depois de visitar as minas de Jaraguá permaneceu algum tempo na fazenda do governador Franca e Horta, não tendo percorrido o interior da Província. No período da sua estadia na cidade participava de festas, jantares e bailes, quando "circulou o boato desagradável, de que o Porto de Lisboa fora bombardeado pelos ingleses, e que a declaração de guerra entre as duas potências era esperada a qualquer momento [...] Mas, em breve, chegaram notícias de que Sua Alteza Real, o Príncipe Regente, deixara Portugal, com toda a Corte, e embarcara para o Brasil, escoltado por uma esquadra inglesa, comandada por Sir Sidney Smith. [...] Dez dias depois, chegaram notícias de que havia aportado à Bahia, sendo recebido com todas as demonstrações de alegria popular, procissões, fogos de artifício, etc. Na expectativa da notícia de sua chegada ao Rio de Janeiro, preparei-me para partir, e dediquei os dias restantes a segunda excursão às minas de ouro, e a algumas visitas de despedida aos meus amigos dos arredores de São Paulo" ${ }^{166}$. E assim, no início do ano de 1808 partiu de São Paulo com destino ao Rio de Janeiro.

Para a visualização dos locais visitados pelos viajantes, a seguir inserimos a "Planta da Imperial Cidade de S. Paulo", de 1841, elaborada por Rufino José Felizardo e Costa ${ }^{167}$.

\footnotetext{
${ }^{164}$ Daniel Parish Kidder. Reminiscências de viagem..., op. cit., p. 229.

${ }^{165}$ Ibidem, p. 232.

${ }^{166}$ John Mawe. Viagens ao interior do Brasil..., op. cit., p. 74.

167 "Esta cópia do mapa original, de 1841, foi encomendada por Affonso Taunay, que o fez reproduzir, emoldurado pelos principais monumentos da cidade ilustrados por Dutra. Dois artistas encarregaram-se desse trabalho: Francisco Sonsani, em 1915, e J. Domingos dos Santos Filho, em 1918. Esta cópia foi impressa em 1954, e está aqui reproduzida por conter alguns desenhos de Dutra que não correspondem às aquarelas conhecidas e podem ter-se perdido desde a última vez que foram copiadas". Pedro Côrrea do Lago. Iconografia Paulistana..., op. cit., p. 143.
} 


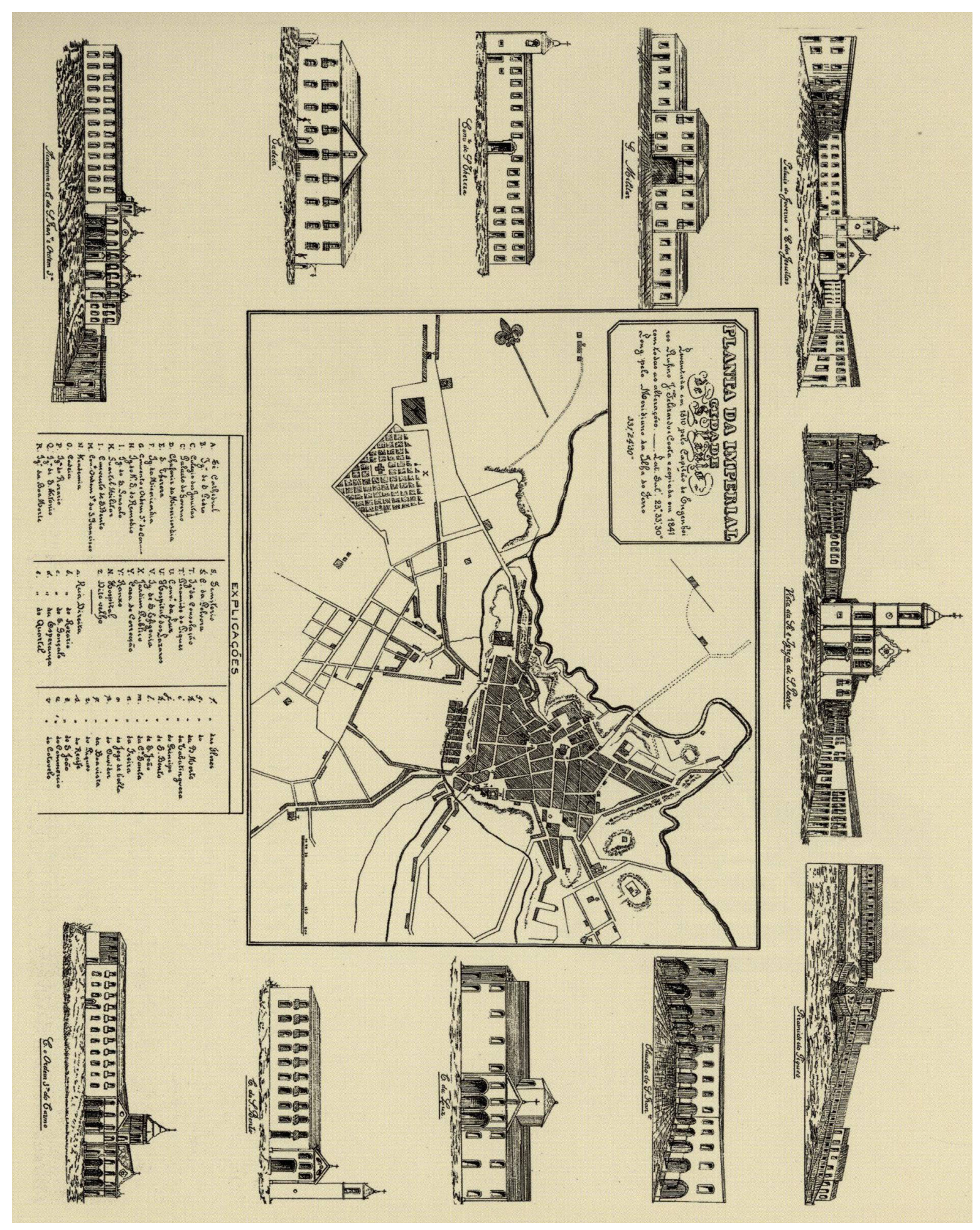




\subsection{Visitas a outras vilas}

Em 1823, Pink viajou da cidade para os distritos açucareiros, visitando Jundiaí, Campinas, Mogi-Mirim, Itu, Porto-Feliz e Sorocaba. Kidder, em 1839, fez percurso semelhante, com os objetivos missionários de propagar os ensinamentos de Cristo e distribuir exemplares da Bíblia, passando por Jundiaí, Campinas, Indaiatuba, Itu e Sorocaba. Devido à similaridade entre o roteiro dos viajantes, ao longo deste sub-capítulo traçaremos paralelos e relacionaremos as informações sobre as mesmas localidades visitadas.

Pink seguiu da cidade para o interior de São Paulo, uma vez que "F. e eu, havendo decidido por uma viagem através dos distritos de açúcar, nos preparamos para a jornada com os acessórios necessários, tendo conseguido um guia que também serviria como nosso criado, um confiável negro livre de nome José "168.

Jacaré (sic) foi o primeiro lugar onde esteve após deixar a cidade paulista, e nele pernoitou em 26 de junho. Na manhã seguinte viajou para Jundiaí, que é descrita como "um lugarzinho meio repugnante, situado a cerca de uma milha à margem esquerda do rio de onde deriva seu nome. Sobre ele há uma ponte. Compõe-se de duas longas ruas cortadas por outras menores. Sua igreja matriz é dedicada a Nossa Senhora do Desterro Our Lady of the Desert. Possui um hospital. A principal ocupação dos habitantes parece ser a criação de mulas, cavalos e gado. Há algumas plantações de milho e feijão na vizinhança e poucas plantações de cana-de-açúcar"169.

Kidder também visitou Jundiaí, e como Pink, destaca a precariedade da região, apontando inclusive o contraste entre este aspecto e sua importância no cenário paulista:

\footnotetext{
"Fustigando os animais, vencemos as duas léguas que dela nos separavam e com grande alívio chegamos à povoação ao cair da noite. Apesar de sua população de duas a três mil almas e de constituir a vila importante centro comercial, dispunha ela de apenas uma estalagem, e essa mesma pequena, afastada da rua, com muito mais aparência de casa particular que de hospedaria" ${ }^{\prime 170}$.
}

Apesar da aparência decadente, o valor desta região estava na sua posição central no comércio açucareiro e no crescimento da sua produção ao longo do final do século XVIII e durante o XIX. Como apontam Francisco Luna e Herbert Klein:

\footnotetext{
${ }^{168}$ Edmund Pink. A São Paulo de Edmund Pink..., op. cit., p. 86.

${ }^{169}$ Ibidem, p. 87.

${ }^{170}$ Daniel Parish Kidder. Reminiscências de viagem..., op. cit., p. 233.
} 
"Inicialmente, Jundiaí era uma localidade pobre, com unidades agrícolas pequenas movidas pelo trabalho familiar e alguns escravos. Mas o aumento constante nas culturas de gênero alimentícios, em especial o milho, e o início de uma moderna economia açucareira no último quartel do século XVIII geraram profundas mudanças estruturais [...] O impacto das crescentes exportações de açúcar e outros gêneros básicos pode ser visto nos dados de produção de Jundiaí. A produção de açúcar passou de 45 toneladas inicialmente para 316 toneladas em 1836. O milho foi de 150 toneladas para 2.420 toneladas, e outros gêneros alimentícios aumentaram em níveis equivalentes. Não cresceu apenas o volume, mas também o seu valor" $" 171$.

No dia 28 de junho chegou a Campinas, após quase nove horas de viagem a partir de Jundiaí. Sobre a região percorrida considera-a "bem arborizada e apresenta geralmente uma aparência muito melhor, mais sinais de cultivo e mais povoações são encontradas"172.

Kidder quando viajou pela província também notou melhorias no caminho de Jundiaí para Campinas, que inclusive lhe trouxeram lembranças da sua terra natal:

"A manhã estava agradabilíssima; o céu límpido e o ar fresco conquanto logo depois de nascer, o sol fosse aquecendo rapidamente. A estrada que percorríamos, atravessava uma floresta quase plana, com quatro léguas de extensão, ao fim das quais apareceram clareiras e plantações. Durante o dia passamos pela primeira serraria que vimos no Brasil, onde os troncos eram serrados pelo lento e estafante processo manual da serrachicote. Diversos pormenores no aspecto geral da região nos fazia cada vez mais lembrar dos Estados Unidos" ${ }^{173}$.

Ao percorrer o caminho para Campinas, Pink descreve as ruas, as casas de proprietários de fazendas e dos menos abastados, a população e a presença da Estrada Real na região, circunvizinhada por terrenos férteis para o açúcar e o café. Sobre o número de fazendas açucareiras na região, considera ser em torno de $70^{174}$, e com base nas informações coletadas e no que viu durante sua viagem diz: "Provavelmente [Campinas] se tornará a mais importante cidade dos distritos açucareiros "175.

Segundo Maria Thereza Petrone, "desde o começo do século, houve um progresso muito grande em Campinas, progresso esse que, de maneira alguma, pode ser comparado ao de qualquer outra localidade, nem mesmo ao da tradicional terra açucareira de Itu" ${ }^{\prime 176}$.

\footnotetext{
${ }^{171}$ Francisco Vidal Luna e Herbert S. Klein. Evolução da sociedade..., op. cit., p. 70-71.

${ }^{172}$ Edmund Pink. A São Paulo de Edmund Pink..., op. cit., p. 87.

${ }^{173}$ Daniel Parish Kidder. Reminiscências de viagem..., op. cit., p. 235.

174 "A cidade de Campinas (situada px [sic] ao Rio Atibaia) ou São Carlos, a cujo santo sua igreja matriz é dedicada, está situada num pequeno riacho, a pouco mais de uma légua do Rio Atibaia... [...] No distrito de Campinas há em torno de 70 fazendas". Edmund Pink. A São Paulo de Edmund Pink.., op. cit., p. 87 e 89. 175 Ibidem, p. 87.

176 Maria Thereza Schorer Petrone. A lavoura canavieira em São Paulo..., op. cit., p. 46.
} 
O número de propriedades indicado por Pink pode complementar os dados apresentados por Petrone, e apontam o crescimento das propriedades açucareiras em Campinas até meados do século XIX, quando o café passou a superar o cultivo do açúcar e ocupar o posto de destaque no comércio paulista.

TABELA 5 - Número de engenhos e produção de açúcar e de aguardente em Campinas 1775-1854

\begin{tabular}{|l|l|l|l|}
\hline Ano & $\mathbf{N}^{\mathbf{0}}$ de engenhos & Açúcar/arrobas & Aguardente canadas \\
\hline & & & \\
\hline 1775 & 3 & ---------- & 150 \\
\hline 1798 & 37 & 15.139 & 460 \\
\hline 1799 & 37 & 16.875 & 381 \\
\hline 1818 & 60 & 100.000 & --------- \\
\hline $\mathbf{1 8 2 3}$ & $7 \mathbf{0}$ & --------- & -------- \\
\hline 1834 & 82 & 302.100 & \\
\hline 1836 & 93 engenhos/93 destilarias & 158.447 & 7.339 \\
\hline 1852 & 51 & --------- & -------- \\
\hline 1854 & 44 & 62.290 & ------- \\
\hline
\end{tabular}

FONTE: Maria Thereza Schorer Petrone. A lavoura canavieira em São Paulo. Expansão e declínio (17651851). São Paulo: Difusão Européia do Livro, 1968, p. 48.

NOTA: As informações destacadas foram adicionadas por nós à tabela original com base nos dados apontados por Pink.

O viajante inglês apontou Campinas como o grande expoente na lavoura canavieira paulista. Kidder do mesmo modo discorreu sobre esta importância, e considera sua localização um fator significativo, pois ela era ponto de confluência de tropas. Sobre o assunto escreve: "Pela sua posição, o lugar tornou-se o ponto de encontro das tropas que levam açúcar para o litoral e de lá trazem sal e outros artigos. Aí viam-se diariamente animais carregando e descarregando" ${ }^{\text {177 }}$. Além dos aspectos positivos da região, registra os problemas que algumas vezes seus habitantes passaram:

"Conquanto aparentasse mais vida e energia em vários setores comerciais que diversas outras cidades do mesmo porto, ainda assim reclamam que São Carlos passa, de vez em quando por períodos bem difíceis" ${ }^{\prime 178}$.

Pink de Campinas foi para Mogi - Mirim, onde visitou a nova plantação de canade-açúcar do capitão Luiz da Cunha, chamada Tatu e "de tamanho considerável - 4 léguas quadradas - e, com exceção de uma pequena parte ainda em cultivo com cana, milho $e$ feijão, consistia de floresta virgem repleta de bonitas madeiras - as árvores atingiam

\footnotetext{
${ }^{177}$ Daniel Parish Kidder. Reminiscências de viagem..., op. cit., p. 236.

${ }^{178}$ Ibidem.
} 
majestosamente altura de 80 a 100 pés e com diâmetro proporcional, cujo interior, com exceção de onde a madeira foi cortada, permanece intocada pela devastadora mão do homem $" 179$.

Da fazenda Tatu voltou para Campinas e de lá foi para Itu. Sobre Itu mescla elementos sobre sua localização, clima, habitantes e construções, com dados referentes à fertilidade da região e sua produtividade. Ao tratar da madeira agrega sua ocorrência à utilização como combustível necessário nas fazendas açucareiras, mas chama a atenção para a necessidade do reflorestamento pelos fazendeiros, visando evitar a sua escassez:

"Esta é uma grande cidade, a princípio próspera, mas agora em declínio por causa da melhor localização de Campinas para o cultivo da cana-deaçúcar... Os habitantes são principalmente plantadores de cana-deaçúcar, muitos dos quais tiveram a atenção atraída tanto para este local como para as redondezas de Campinas, onde o solo é muito mais rico, com mais madeira, como para o mais distante e mais novo distrito de Piracicaba, onde o solo é ainda mais rico, mais ainda no início do cultivo. A essas circunstâncias deve ser atribuído o declínio desta cidade. Os agricultores não dão muita atenção ao reflorestamento depois que as fazendas são desmatadas para a plantação ou a madeira usada na preparação do açúcar. Nas redondezas desta cidade, sendo o lugar dos primeiros cultivadores de cana-de-açúcar na província, em muitas fazendas há, conseqüentemente, grande escassez do combustível necessário" ${ }^{180}$.

Kidder também visitou as terras ituanas, tendo passado antes por Indaiatuba, onde descansaram e deram de comer para os animais. No caminho para Itu atravessou o rio Tietê, já próximo desta localidade, e sua descrição apresenta-o através de informações como sua navegabilidade e percurso:

"Esse rio é dos mais caudalosos da província de São Paulo. Nasce próximo ao ponto mais elevado da Serra do Mar, e, depois de receber numerosos tributários, continua em direção ao Poente, num percurso total de quase setecentas milhas, até desaguar no Paraná. Ao longo de todo o seu curso, contam-se nada menos de quarenta e seis cachoeiras e corredeiras. Mesmo assim, porém, é navegável em canoas, constituindo a artéria líquida que vai ter à Província de Mato Grosso, e, mais além, ao Paraguai" ${ }^{\prime 181}$

Ao chegar na vila expõe que o seu interesse por uma região é proporcional ao número de habitantes, aos melhoramentos e à fertilidade e gêneros cultivados, conforme o trecho a seguir:

\footnotetext{
${ }^{179}$ Edmund Pink. A São Paulo de Edmund Pink..., op. cit., p. 90.

${ }^{180}$ Ibidem, p. 90-91.

${ }^{181}$ Daniel Parish Kidder. Reminiscências de viagem..., op. cit., p. 240.
} 
"Depois de atravessar o Tietê, o lugar a que nos dirigíamos, Itu, fica apenas a uma légua de distância. A viagem ia-se tornando cada vez mais interessante à medida que notávamos o aumento de densidade da população e surgiam os melhoramentos do lugar. O município de Itu é considerado como um dos mais populosos e férteis da província. Aí residem diversos cidadãos de destaque, sendo que um deles teve a gentileza de nos fornecer os seguintes informes relativamente a assuntos do interesse geral: Escolas [...] Edifícios [...] Profissões liberais [...] A sociedade a que fomos apresentados nessa localidade, fez que nossa permanência aí se tornasse extremamente interessante e proveitosa para os fins a que tínhamos em mira. Alguns pomares da cidade estavam muito bem tratados e produziam excelentes romãs e magníficas espécies de uva. Em certas chácaras, fabricam vinho de muito boa qualidade, para uso próprio" ${ }^{" 182}$.

Ao deixar Itu, Pink seguiu para a Fábrica de Ipanema e de lá para Sorocaba, em que o viajante destacou sua prosperidade, a criação de gado e cavalos e o comércio de mulas.

No dia 27 de julho [1823], depois ter percorrido as regiões açucareiras, voltou à cidade de São Paulo, onde traçou um panorama dos locais visitados:

"Domingo, 27 de julho [...] O tempo estava extremamente frio, com chuva de granizo, e achamos nossos capotes realmente agradáveis. Dando uma idéia geral sobre a região pela qual viajamos, como havia declarado antes, a terra nas cercanias da cidade é pobre e pouco arborizada, melhorando em qualidade quando se atinge Campinas ou São Carlos, continuando assim até quase Mogi - Mirim e seguindo a direção de Piracicaba, onde de novo parece assumir uma fertilidade de qualidade muito superior, novamente decaindo em qualidade na direção de Porto Feliz e Itu. Nos distritos açucareiros, geralmente a aparência da região é extremamente bela. Aquelas partes ainda não cultivadas consistem de florestas virgens da mais luxuriante beleza, com árvores se elevando à altura majestosa e de tamanho proporcional, cruzadas por rios em todas as direções. As estradas necessitam de melhorias para permitirem a passagem de carroças. Atualmente, a totalidade da produção é transportada no lombo de mulas; em muitos lugares só são encontradas trilhas de mulas em vez de estradas abertas. Nas imediações de Sorocaba é encontrada uma ótima espécie de caulim e na Fábrica de Ipanema há uma pedra de textura suficientemente boa para afiar delicados instrumentos cortantes. Várias drogas são encontradas nas vizinhanças de Itu e a cultura da cochonilha pode alcançar considerável sucesso. Mas essas coisas nunca serão especuladas enquanto estrangeiros mais empreendedores e industriosos que os portugueses ou os brasileiros não se estabelecerem aqui. Os brasileiros estão completamente satisfeitos em continuar da velha maneira. Madeiras da melhor qualidade e beleza existem em abundância na província, mas devido ao atual estado das estradas, etc. as grandes toras não podem ser transportadas para a costa. Nas imediações da fábrica de Sorocaba, dr. Engler descobriu 130 espécies diferentes de madeira. Na nossa volta,

${ }^{182}$ Daniel Parish Kidder. Reminiscências de viagem..., op. cit., p. 240-242. 
encontramos em São Paulo a maior ansiedade demonstrada por parte dos habitantes pelas notícias vindas da capital". ${ }^{183}$

Após a segunda visita deixou São Paulo em 21 de outubro de 1823 e seguiu rumo ao Rio de Janeiro. Seu relato é interrompido no dia 29 de outubro, quando ainda viajava para seu destino: "Partimos deste rancho [nas proximidades da cidade de São José] nesta noite, por volta das 7 horas, para desfrutar da companhia de..." ${ }^{\text {184 }}$. No dia 15 de setembro de 1825 retornou à Londres.

Já o pastor metodista, de Itu foi para Sorocaba onde pernoitou e no dia seguinte visitou a Fábrica de Ipanema. Desta localidade iniciou a viagem de regresso para a cidade de São Paulo em que realizou algumas atividades e reviu alguns conhecidos. Desceu até Santos, e lá fez uma breve excursão por São Vicente e outra por uma refinaria de açúcar, e com isto embarcou no vapor "Paquete do Norte" para o Rio de Janeiro.

O último capítulo do relato de Kidder consiste no mapeamento da situação da ação missionária em São Paulo e a descrição das suas atividades religiosas durante a permanência na Província. Discorre também sobre sua proposta entregue à Assembléia Provincial de fornecer gratuitamente Bíblias traduzidas para o português às escolas primárias. Sobre os resultados desta empreitada escreve:

\begin{abstract}
"Ao finalizarmos este capítulo, torna-se necessário acrescentar que, devido às injunções e intrigas comuns à maioria das organizações políticas, a decisão da Assembléia, relativamente à nossa proposta, foi procrastinada mais do que esperavam os partidários da idéia e que a última informação que tivemos sobre a questão foi numa conversa com o Presidente da Assembléia. [...] Soubemos mais tarde, pela imprensa que a Comissão à qual o projeto fora encaminhado, ou provavelmente seu presidente, em flagrante contradição com o que nos havia prometido antes e cedendo aos receios infundados do bispo, entregara à Secretaria da Assembléia um parecer desfavorável à proposta.

Provavelmente, nunca mais foi ela objeto de deliberação. Também, para o bom nome da Província, jamais foi abertamente rejeitada" ${ }^{2185}$.
\end{abstract}

A leitura dos relatos nos aponta a presença de um viés econômico e uma concepção utilitarista que permeia a descrição das regiões pelos viajantes. Estes associam qualidades positivas aos locais nos quais a ação humana se faz mais presente, modificando paisagens com suas plantações, construindo estradas e sobrepujando as dificuldades naturais. $\mathrm{Na}$ cidade, ou na visita a fazendas, quando estavam percorrendo determinado caminho, enfim,

\footnotetext{
${ }^{183}$ Edmund Pink. A São Paulo de Edmund Pink..., op. cit., p. 94-95.

${ }^{184}$ Ibidem, p. 97.

${ }^{185}$ Daniel Parish Kidder. Reminiscências de viagem..., op. cit., p. 289-290.
} 
por onde passaram apresentaram os recursos naturais e a eles agregaram valores e potencialidades para a sua utilização e exploração pelo homem. 


\subsection{A agricultura paulista e a visita à Fábrica de Ferro de Ipanema}

Para os viajantes a paisagem é o espaço em que estavam encerrados elementos úteis e que eles mapeiam, definem e registram em seus relatos ${ }^{186}$. Desta forma, consideram a Província de São Paulo dotada de um rico solo, clima favorável para agricultura, recursos minerais, matéria-prima em abundância e potencialidade de realização material do homem, enquadrando-o em um mundo de expectativas de crescimento e enriquecimento ao explorar através de seu trabalho o meio que o cerca. Todavia, na concepção dos viajantes, há uma disparidade entre a capacidade produtiva da região paulista e sua utilização.

Conforme aponta Mawe, em sua descrição de São Paulo, o gado e o leite são fontes de lucro, a fertilidade da região abarrotava o mercado com uma grande variedade de frutas e legumes de boa qualidade, assim como os frangos, leitões, perus, gansos e patos, vendidos a preços baratos. Entretanto, para ele a riqueza do solo e a agricultura, vista como "uma fonte de riqueza constante e inexaurível" 187 , são negligenciadas, porque o lavrador é desmerecido e "considerado como pertencente a uma classe muito inferior, em comparação com a respeitabilidade dos mineiros" $" 188$. O tom é de reprovação:

"É doloroso conservar-se um território que, pelo seu solo fértil e clima invejável, merece ser denominado um paraíso, abandonado e solitário como o Éden, depois da queda, enquanto seus enfatuados possuidores, como a geração de Caim, famintos de ouro, conservam-se afastados do rico banquete que a natureza aqui lhes oferece" ${ }^{\text {"189 }}$.

\footnotetext{
${ }^{186}$ Flora Süssekind aponta nos relatos dos viajantes naturalistas o olhar que guia a descrição das paisagens e, muitas vezes constitui filtros pré-determinados a condicionar seu modo de viajar: "É curioso como, nesses relatos, o olhar que habitualmente se deseja imparcial, desapaixonado, à espera do que vier, do cientista e mesmo do viajante comum, se converte, desde o início das expedições [científicas], em observação interessada, com itinerário, objetivos e modos-de-ver sabidos de cor. Antes mesmo de se chegar ao destino, antes de se iniciarem as caçadas, a coleta do material, os contatos possíveis com tribos indígenas, o levantamento hidrográfico, as picadas mato adentro, os chefes de expedição parecem ter bem clara a definição de uma paisagem útil e dos objetos e espécimes a serem colecionados e registrados nas pranchas dos desenhistas itinerantes. Nisso não apenas os relatos, mas o modo mesmo de viajar desses estudiosos se distingue radicalmente dos outros visitantes do país do mesmo período”. Flora Süssekind. O Brasil não é longe daqui..., op. cit., p. 114.

187 John Mawe. Viagens ao interior do Brasil..., op. cit., p. 66.

${ }^{188}$ Ibidem.

189 Ibidem, p. 69.
}

Sobre a busca do ouro pelos paulistas escreve: "Enquanto os paulistas ficaram em seu território, não houve hostilidade contra o governo; mas depois de terem constituído grandes propriedades, e aumentado de número, não puderam a beleza do clima e a fertilidade do solo fixá-los no terreno que ocupavam. Começaram a abandoná-lo para irem à cata do ouro, atravessando regiões desconhecidas e afrontando fadigas de todo gênero. Não é de surpreender que, tendo vencido tantos obstáculos e perigos para explorar e possuir ricos distritos, tenham aspirado manter seus direitos por todos os meios ao seu alcance. Os homens audazes eram os únicos que na colônia podiam pôr tudo em movimento. Conheciam sua superioridade sobre o resto dos habitantes, e esse sentimento os levava a se contraporem ao governo, que timbrava em lhes prodigalizar epítetos imerecidos. É, todavia, sabido que, na guerra colonial de 1770 , as tropas do governo português, sem o auxílio dos paulistas, teriam feito uma triste figura no Paraguai, no vasto território de Mato Grosso e nos 
Mas não só a agricultura é descurada, o setor da pecuária bovina e a "indústria do leite" são vistos como precários, com o agravante de poderem fornecer inúmeras possibilidades de atividade e lucro. Este quadro desperta no viajante tal indignação, que escreve:

"Em nenhum ramo de trabalho rural os fazendeiros se descuidam tanto quanto no tratamento do gado. Não cultivam pastagens, não constroem cercados, nem armazéns de forragem para a época de escassez. As vacas não são ordenhadas com regularidade; consideram-na mais como ônus do que como fonte de renda. Precisam de sal, de quando em quando, que lhes é dado de quinze em quinze dias, em pequenas porções. A indústria do leite, se assim a podemos qualificar, é conduzida com tão pouco asseio, que a pequena quantidade de manteiga fabricada fica rançosa em poucos dias, e o queijo de nada vale. Neste ramo essencial estão deploravelmente atrasados; raramente vê-se uma fazenda com instalação que se possa olhar. Por falta de lugares apropriados onde conservar seus produtos, são [sic] forçados a colocá-los misturados, em montes, e não é raro encontrar-se café, algodão, milho e feijão atirados nos cantos de um celeiro úmido, coberto com couro cru. A metade se estraga, invariavelmente, devido ao mofo e à podridão e o restante fica muito deteriorado, em conseqüência desta negligência, preguiçosa e estúpida" ${ }^{\prime 190}$.

O pastor metodista norte-americano Daniel Kidder, três décadas após Mawe, também critica a falta de trabalho e aproveitamento dos recursos naturais ofertados por Deus a negligentes habitantes. Quando viaja de Campinas para Indaiatuba, passando pelo Bairro de Boa Esperança nota o rico solo da região. O contraste está entre tal riqueza, que só espera a labuta dos homens, com a aparência paupérrima da população e suas moradias. Sobre isto diz:

\begin{abstract}
"A passagem era tão estreita que dificilmente dava para dois animais, lado a lado. O solo da região era bastante rico, deixando ver, em certos lugares, profunda marga preta. $\mathrm{O}$ primeiro núcleo por que passamos chamava-se Bairro da Boa Esperança. Sua aparência não era de molde a despertar entusiasmo. Algumas casinholas mal tratadas e uns habitantes em iguais condições, eram (sic) tudo quanto compreendia esse núcleo, paupérrimo. Como é comum ver-se o homem retribuir com indiferença e indolência as dádivas que a Providência sobre ele esparze em profusão!"191.
\end{abstract}

\footnotetext{
países do noroeste, onde penetraram e formaram como cavalarianos, fizeram a guerra de um modo particular, e empregaram tantos estratagemas e surpresas que os espanhóis, tomados de terror pânico, foram repelidos de seus domínios. [...] Julga-se que todo o território ao norte do Rio da Prata seria uma conquista fácil, que os paulistas sozinhos se encarregariam de efetuar gradualmente. Devo observar, contudo, que longe de descontentes e rebeldes, como falsamente os acusaram, são os mais fiéis vassalos do Príncipe”. John Mawe. Viagens ao interior do Brasil..., op. cit., p. 186.

190 Ibidem, p. 67.

${ }^{191}$ Daniel Parish Kidder. Reminiscências de viagens..., op. cit., p. 239.
} 
O mote da displicência é constante, aparece em mais de um ramo e é encontrada na atividade madeireira, de acordo com Mawe e Pink. Para eles, a abundância de madeira nas terras de Piratininga é precariamente explorada pelo homem ${ }^{192}$. Nas margens do rio Tietê, Mawe descreve um panorama de grande potencialidade, porém não devidamente cultivado: "Nas suas margens há lugares verdadeiramente dignos de inveja; belas e ricas terras cobertas de madeira capazes de satisfazer, se devidamente cultivadas, não somente as necessidades, mas os luxos da vida, num grau centuplicado ${ }^{~} 193$.

Para Pink, a precariedade da exploração da madeira nas imediações da Fábrica de Ipanema é decorrente da má conservação das estradas e faz parte de um quadro mais amplo de uma série de riquezas inexploradas: uma ótima espécie de caulim encontrada em Sorocaba, a pedra de boa textura localizada na fábrica e adequada para afiar instrumentos delicados, a ocorrência de drogas nas vizinhas de Itu e a cultura da cochonilha. A causa de tal situação é creditada a um fator semelhante àquele apontado por Kidder: negligência por parte dos habitantes dessas regiões, acrescentando que tal quadro só seria revertido com a atuação de estrangeiros mais empreendedores que os portugueses ${ }^{194}$.

Segundo Tania Quintaneiro: "Predominava também entre os viajantes dessa origem [ingleses e norte-americanos] a convicção de que os portugueses e seus descendentes, ancorados no imobilismo, desencorajavam qualquer iniciativa em favor do progresso e que, por isso, não haviam avançado quase nada durante os trezentos anos em que estiveram instalados na América do Sul que, para os primeiros, continuava a encarnar a barbárie"195.

O olhar que vê potencialidades, utilidades e lucro nos caminhos percorridos também escreve sobre o patamar de exploração por aqueles que poderiam se utilizar dos recursos em seu entorno. José Carlos Barreiro, através da desconstrução das representações

\footnotetext{
${ }^{192}$ No ano de 1810 viajou pela Capitania de São Paulo o comerciante britânico William Henry May. A convite do cônsul inglês James Gambier, veio com uma expedição a terras paulistas em busca de madeira útil para a indústria naval inglesa. Sobre esta viagem ver seu relato. William May. Diário de uma viagem da Baía de Botafogo à cidade de São Paulo (1810). Trad. Jean Marcel Carvalho França. Rio de Janeiro: José Olympio, 2006. Oliveira Lima, com base nos dados do Correio Braziliense, destaca o interesse britânico sobre a madeira brasileira quando aborda o Tratado Comercial de 1810, ano de vinda de May para terras paulistas: "Como de tudo quanto faz no domínio internacional, costuma a Inglaterra avisadamente tirar cabedal, não contente com as muitas concessões do tratado de comércio, foi naquele outro tratado de paz convênio político e não mercantil - que lord Strangford arranjou maneira de inserir uma cláusula facultando à Inglaterra, em recompensa dos grandes serviços prestados à família real portuguesa pela marinha real inglesa, o referido privilégio de 'fazer comprar, e cortar madeiras para a construção dos seus navios de guerra, nos bosques, florestas e matas do Brasil (excetuando nas florestas reais, que são designadas para uso da marinha portuguesa), juntamente com permissão de poder fazer construir, prover ou reparar navios de guerra nos portos e baías daquele império' ". Oliveira Lima. Dom João VI no Brasil.., op. cit., p. 257.

${ }^{193}$ John Mawe. Viagens ao interior do Brasil..., op. cit., p. 69.

${ }^{194}$ Edmund Pink. A São Paulo de Edmund Pink..., op. cit., p. 95.

195 Tânia Quintaneiro, Retratos de mulher..., op. cit., p. 27.
} 
dos viajantes sobre a miséria, indolência e aproveitamento rudimentar dos recursos naturais, considera o discurso da pobreza como decorrência dos parâmetros de trabalho sistemático e racionalizado, do máximo aproveitamento do tempo para a acumulação de riqueza e à concepção de propriedade nascida na Europa durante o século XIX e propagada em todo o mundo. Tais balizas são utilizadas pelos viajantes para caracterizar a realidade com que se deparavam ${ }^{196}$.

\footnotetext{
${ }^{196}$ José Carlos Barreiro, Imaginário e viajantes no Brasil do século XIX..., op. cit.
} 


\section{A Fábrica de Ferro de São João de Ipanema}

A Fábrica de Ipanema ${ }^{197}$ foi visitada tanto por Edmund Pink como por Daniel Parish Kidder. Apesar do intervalo de tempo entre as viagens, o primeiro esteve no local em 1823 e o segundo em 1839, os apontamentos possuem o mesmo tom: reprovação, pelo abandono e o descaso com um estabelecimento que poderia gerar riquezas tanto para a Província como para o Brasil ${ }^{198}$.

No ano de $1810^{199}$ o Príncipe Regente ${ }^{200}$ através de um decreto real incentivou a fundição de minério de ferro para a fabricação de objetivos úteis à população. Segundo José de Araújo Filho: "O morro de Araçoiaba, no então termo da vila de Sorocaba, na Capitania de São Paulo, foi o mais velho local conhecido como possuidor do minério de ferro. As forjas que aí funcionaram nos finais do século XVI e princípios do século XVII, com os Afonso Sardinha, dispensaram maiores comentários no sentido de as colocarem como pioneiras no Brasil, como fábricas de algumas das utilidades para os colonos. Mas, os primeiros trabalhos dos Sardinha, assim como os que se tentaram nos séculos seguintes,

\footnotetext{
197 "Em dezembro, no dia 4, [...] uma carta régia, publicada na 'Coleção de Leis do Brasil em 1810', [...] criava o chamado 'Estabelecimento Montanístico das Minas de Ferro de Sorocaba'. Foi o primeiro nome da Fábrica de Ferro de Ipanema [...] Em meados de novembro [1811], a Junta [de acionistas da Fábrica] acertou que o estabelecimento montanístico passasse a se chamar Real Fábrica de Ferro de São João de Ypanema". José Monteiro Salazar. Araçoiaba \& Ipanema; a história daquela maravilhosa região, desde as forjas de Afonso Sardinha até a Real Fábrica de Ferro, Sorocaba, SP. São Paulo: Ministério da Marinha/IBAMA/Governo do Estado de São Paulo, 1998, p. 88 e 91.

${ }^{198}$ Nilton Pereira dos Santos analisa como a Fábrica de Ipanema foi tratada pela política governamental desde sua fundação (1810) até o seu fechamento (1895), destacando ora o empenho régio em desenvolvê-la ora o abandono, e aponta serem estes quadros parte de diferentes contextos a que estava inserido o estabelecimento e das diferentes propostos da Coroa para ele. Nilton Pereira dos Santos. A fábrica de ferro São João de Ipanema: economia e politica nas últimas décadas do Segundo Reinado (1860-1889). Dissertação de Mestrado. Departamento de História/Faculdade de Filosofia, Letras e Ciências Humanas/Universidade de São Paulo, 2009.

199 "A Carta Régia de 4 de dezembro de 1810 que criou o 'estabelecimento montanistico da minas de Sorocaba', chamado depois de Real fábrica de ferro São João de Ipanema, previa a fundação de uma companhia de capital misto, de modo que a Coroa compartilhasse com particulares os custos da criação do empreendimento. Inicialmente, o Estado concederia terras e matas para exploração, forneceria 100 escravos e os bois necessários aos trabalhos, além de mandar vir da Suécia trabalhadores especializados e um diretor para a fábrica, pagando-lhe os respectivos ordenados. Os particulares, por sua vez, ao adquirirem parte na companhia que estava dividida, inicialmente, em 13 ações de $800 \$ 000$ réis cada, arcariam com a compra de maquinário e demais serviços necessários ao crescimento do estabelecimento, repartindo o lucro que viesse na medida em que a companhia se estabelecesse". Ibidem, p. 25. [Itálico do autor].

200 "Já em 27 de maio de 1795 Luiz Pinto de Souza em nome d’El-Rey manda aos governadores das capitanias instruções para remover dois dos mais pesados tributos pagos pela Colônia: o monopólio do sal e o imposto de importação sobre o ferro. Além disso, nesse mesmo ofício vem declarado que fica livre a quem quiser estabelecer fábricas de ferro, ou manufaturas de instrumentos deste gênero [...] De Lisboa continuavam a recomendar aos Vice-Reis e aos governadores animassem as empresas de mineração do ferro. Estas autoridades, entretanto, pouco podiam fazer, pois lutavam com as conseqüências da situação anterior, asfixiadora das tentativas particularistas [...]". João Pandiá Calógeras. O ferro, ensaio de história industrial. Revista do Instituto Histórico e Geográfico de São Paulo, 1904, vol. 9, p. 56-57.
} 
não alcançaram a importância dos que organizaram no local, a partir de 1810, quando o próprio governo português, então sediado no Rio de Janeiro, tomou a iniciativa de explorar, em Araçoiaba, nas bases técnicas mais avançadas da época, o minério, que até então aquele momento desafiara os esforços dos pioneiros coloniais"201.

A coroa portuguesa com o objetivo de desenvolver a indústria siderúrgica no Brasil contratou o Barão Luís Guilherme von Eschwege, alemão formado na Universidade de Göttingen. Entre 1802-1829 e 1835-1836 trabalhou com minas e metalurgia para a Coroa portuguesa, tanto em Portugal como no Brasil. Nas terras americanas se dedicou principalmente na organização de um gabinete minerológico-geognóstico. Em 1833 publicou em Berlim a obra Pluto Brasiliensis, em dois volumes, e no que concerne à Província de São Paulo trata, dentre outros temas, da ocorrência de ouro na região e da Fábrica de Ferro de Ipanema.

Ao tratar da fábrica critica a má administração da Coroa em permitir que péssimos diretores ocupassem a sua direção, porque apesar das dificuldades a instalação tinha capacidade produtiva e, contava ainda com a "proximidade do porto de Santos do qual não dista mais de 26 léguas, por excelente rodovia, [e] permitia, mais do que qualquer outra, a esperança de maiores resultados, vale dizer, benefícios que satisfazem de modo geral ao governo e ao Estado, mas nunca aos acionistas"202.

O contraste entre as condições favoráveis com os parcos resultados e a baixa produtividade também é apresentado por Pink e Kidder ${ }^{203}$. O primeiro, após deixar Porto Feliz em 19 de julho seguiu para a Fábrica de Ipanema, onde chegou na manhã do dia seguinte e pousou na casa de um dos alemães trabalhadores do estabelecimento. Sobre a sua localização escreve:

"Essa fábrica está situada nas proximidades da base da montanha Arassoiava - uma corruptela de Guarassoiava, significando cobertura do

\footnotetext{
${ }^{201}$ José R. de Araújo Filho. O minério de ferro no Brasil no século XIX. In.: Sérgio Buarque de Holanda (org.). História Geral da Civilização Brasileira. O Brasil monárquico: declínio e queda do Império..., op. cit., p. 19-20.

${ }^{202}$ Wilhelm Ludwig von Eschwege. Pluto Brasiliensis. Belo Horizonte: Ed. Itatiaia; São Paulo: Edusp, 1979, v. 2 , p. 260.

${ }^{203}$ O francês Auguste de Saint-Hilaire na sua segunda viagem pela Província de São Paulo em 1822, ao deixar o caminho que percorria desde Minas Gerais, no dia 22 de abril se viu perto da Vila das Areias e nas proximidades do Rancho da Estiva, onde cruzou com tropas carregadas, dentre outros produtos com ferro. Sobre o metal escreve: "É verdadeiramente vergonhoso que num país onde este metal é tão abundante, procede ainda do estrangeiro grande parte do que consome. É evidente que seria prestar real serviço ao Brasil sobrecarregar o ferro de impostos consideráveis ao entrar na Capitania forçando-se, assim, os filhos da terra a fazer uso das riquezas que tem à mão". Auguste de Saint-Hilaire. Segunda viagem do Rio de Janeiro a Minas Gerais e a São Paulo, 1822. Trad. Vivaldi Moreira. Belo Horizonte: Ed. Itatiaia; São Paulo: Edusp, 1974, p. 99.
} 
sol, ou sombra do sol, por causa da grande extensão de terreno sombreado por ela, [ilegível] sol aparece no horizonte - produzindo minério de ferro em grande quantidade e riqueza, rendendo mais de $80 \%$ de metal. O Rio Ipanema corre à direita da fábrica e suas águas foram aproveitadas para todos os propósitos exigidos, através do represamento ou mesmo com comportas, etc. de maneira a alimentar os vários canais abertos que cruzam a fábrica. [...] Foi construído um prédio adequado para refinar, fundir e forjar este ferro. Carvão vegetal é amplamente usado uma vez que nenhum carvão mineral foi achado até agora, mas diz-se que ele existe nas redondezas. A região tem madeira em abundância na vizinhança. Muitas das construções são feitas com um excelente tijolo amarelo, igual aos melhores manufaturados nas redondezas de Londres. A pedra calcária encontrada nas redondezas é de excelente qualidade e foi construído um forno para queimar alguma" ${ }^{204}$.

Conforme descreve, a região da fábrica é dotada de todos os recursos para o seu pleno funcionamento, está localizada próxima ao rio $^{205}$, há madeira abundante na região e as construções são adequadas. Entretanto, quando chegou ao local e foi apresentar seus cumprimentos ao diretor Rufino José Felizardo Costa que assumira em 1821, no posto a cerca de um ano, chegou a conclusão de que ele desconhecia "totalmente a natureza do trabalho que tem que superintender"206. Com isto, a capacidade produtiva do estabelecimento não é explorada ao máximo e, uma das conseqüências, o autor apresenta em números: "O governador declarou que este ano eles haviam fundido apenas 3.000 arrobas de ferro $=$ [incompleto] toneladas. Eles podem fundir 500 arrobas por semana e produzir cerca de 30 arrobas de ferro em barra",207.

O baixo rendimento associado e em decorrência do descaso são resultados de uma péssima administração ${ }^{208}$. Detectado o foco do problema, concluí: “Esse é um

\footnotetext{
${ }^{204}$ Edmund Pink. A São Paulo de Edmund Pink..., op. cit., p. 93.

205 "Dois rios a circundam, sendo o mais importante, e mais próximo, o Ipanema e, do lado sul, o antigo Serapuhy; este, porém, bem mais distante. Ainda, na parte central do Araçoiaba nascem alguns pequenos riachos e um relativamente maior e mais importante, o antigo Rio das Furnas, hoje o chamado Ribeirão do Ferro, o qual, ao descer a vertente, forma o ainda hoje chamado Vale das Furnas. Ele nasce no Monte do Chapéu e corre primeiro do norte para o sul e, depois de passar pelo Vale de Furnas, torce bruscamente e muda radicalmente de direção, fazendo uma grande curva e passando a correr do sul do sul para o norte, indo desaguar, afinal, no Ipanema. Do lado nordeste, apresentam-se três cabeços conhecidos como Cabeço do Ferro, o Cabeço Vermelho e o Cabeço Araçoiaba e, no alto, a montanha apresenta como que um grande platô, onde existem várias lagoas”. José Monteiro Salazar. Araçoiaba \& Ipanema.., op. cit., p. 2.

${ }^{206}$ Edmund Pink. A São Paulo de Edmund Pink..., op. cit., p. 93.

${ }^{207}$ Ibidem.

208 "Pensada para ser uma companhia de capital misto, a fábrica deveria depois de montada ser mantida só com o dinheiro da venda do ferro, o que significava custear as gratificações dos operários, o transporte e viagens, a compra de maquinário e a contratação de eventuais serviços, como o fornecimento de mantimentos, além de dar algum lucro aos acionistas. Contudo, como as vendas da fábrica não eram suficientes para cobrir seus custos, criou-se o hábito de pagar os funcionários com parte da produção, criando um circulo vicioso que culminou com a crise enfrentada pela companhia logo após a independência do país". Nilton Pereira dos Santos. A fábrica de ferro São João de Ipanema..., op. cit., p. 41.
} 
estabelecimento que, nas mãos de uma pessoa hábil, com capital suficiente para manter a fábrica em pleno funcionamento, pode se tornar um negócio muito lucrativo" ${ }^{\text {,209 }}$, todavia o quadro visto não foi nada animador: “A conseqüência é que está caminhando rapidamente para a ruína, ${ }^{, 10}$.

Deixando a fábrica, seguiu caminho para a cidade de Sorocaba, onde chegou no dia 25 de julho. No relato destaca a sua prosperidade e uma população de quase 2 mil habitantes. Aponta a criação de gado e cavalos como a principal atividade dos moradores e algum cultivo de cana-de-açúcar, algodão, milho e vegetais. Considera o comércio de mulas a maior riqueza da região, que "trazidas do Sul para essa cidade onde é organizado um mercado (ou feira) para sua venda, no qual comparecem os negociantes das minas e de outras províncias do Norte, para trocar suas mercadorias, trocar por outras [mulas] ou comprar a dinheiro ${ }^{, 211}$.

A crítica à situação decadente da Fábrica de Ferro é complementada e maximizada quando analisa a proximidade entre ela e o rico comércio sorocabano de mulas, porque as atividades neste estabelecimento poderiam ter um grande crescimento com o intenso fluxo de animais e dos condutores das tropas. Conforme registra:

"Aqui é coletado o imposto arrecadado pelo governador (sobre as mulas do Sul). Calcula-se que anualmente chegam aqui 24.000. Estivesse a Fábrica de Ipanema em pleno funcionamento e conduzida com sucesso, tornaria esse lugar a Birmingham* do Brasil"212.

Daniel Kidder no ano de 1839 também visitou a Fábrica de Ipanema. Na ocasião de sua viagem pelo interior da Província de São Paulo, de Itu seguiu para Sorocaba e de lá para o estabelecimento instalado "em um lindo vale ao sopé do morro Guarassajava"״13. Segundo o viajante sua atenção despendida no tema se dá porque considera ser "este o único estabelecimento do gênero em todo o Império, [e] merece que lhe dispensemos um momento de nossa atenção, principalmente porque sua história, serve para mostrar a inconveniência dos monopólios governamentais ${ }^{, 214}$

\footnotetext{
${ }^{209}$ Edmund Pink. A São Paulo de Edmund Pink..., op. cit., p. 93.

${ }^{210}$ Ibidem

211 Ibidem, p. 94.

${ }^{212}$ Ibidem.

* Cidade da Grã-Bretanha localizada à margem do rio Rea, na parte sudoeste da ilha, que foi o berço da Revolução Industrial Inglesa.

${ }^{213}$ Daniel Parish Kidder, Reminiscências de viagem e permanência nas Províncias do Sul do Brasil..., op. cit., p. 250.

${ }^{214}$ Ibidem.
} 
No local foi recebido pelo diretor, o Major Bloem, nomeado no início de 1835, com grande cortesia e disposição em facilitar a visita do viajante pelas estruturas da fábrica. Kidder a descreve nas seguintes palavras: "O estabelecimento é um próprio do governo e consiste em seis ou oito prédios onde se faz a redução e fundição do ferro. Existe ainda, uma grande casa onde reside o diretor e diversos outros prédios menores, ocupados pelos operários e suas famílias, dos quais, por ocasião da nossa visita, vinte e sete eram alemães $^{, 215}$.

Discordando de Pink e de Eschwege, considera um dos primeiros problemas apontados a forma como foi estruturada a fábrica, despendendo recursos e energia para o transporte do mineral de onde ele é extraído para o local da fundição. Como afirma:

"Para que fosse possível utilizar as águas de riacho, as oficinas foram construídas a grande distância da jazida. Como primeira conseqüência, conta-se com a necessidade de grande número de operários para o transporte do minério, em estado natural, da montanha para a fundição. O leitor poderá fazer idéia das condições do serviço de transporte, se dissermos que todo o minério tem que ser carregado no lombo de burros, sendo feitas a mão tanto a carga como a descarga" ${ }^{\text {216. }}$.

Outra dificuldade diz respeito ao completo descaso dos "que foram guindados ao poder, não só eram destituídos de interesse pelos planos de seus antecessores como ainda sentiam-se enciumados, como se o sucesso da empresa fosse grangear [sic] popularidade aos que haviam precedido no governo",217. Soma-se a este quadro "os operários alemães [que] não se conformam com os salários que recebiam porque, apesar de estarem dentro das condições em que foram contratados na Europa, ainda assim eram muito inferiores aos que viam pagar pelo braço escravo contratado. Essa circunstância desagradável, aliada à saudade da pátria, levou muitos deles a desertar,"218a-b.

\footnotetext{
${ }^{215}$ Daniel Parish Kidder, Reminiscências de viagem e permanência nas Provincias do Sul do Brasil..., op. cit., p. 250.

${ }^{216}$ Ibidem.

${ }^{217}$ Ibidem, p. 251.

${ }^{218}$ A - Ibidem.

B - João Pandiá Calógeras e José Monteiro Salazar apontam para a importante presença do elemento africano na Fábrica de Ipanema. Pandiá Calógeras sobre o assunto aponta: "A ordem para guardar sigilo e não alargar o âmbito das experiências, dada por $\mathrm{D}$. Rodrigo José de Menezes, não tinha podido ser observada à risca, em uma capitania onde numerosíssimos eram os escravos vindos da África, metalurgistas natos como bem fazem notar os etnólogos, e dos quais alguns eram empregados de pequenas ferrarias onde o preparo do metal acessoriamente podia ser feito. O testemunho autorizado de D. Luiz Antonio de Souza mostra não importante foi o concurso do Negro para o funcionamento da fábrica de Araçoyaba em 1765-1775". J. Pandiá Calógeras. O ferro..., op. cit., p. 64. Salazar também tece algumas considerações, e aponta que em 1810 Varnhagen após uma visita de três semanas na região traça um plano para a construção de dois fornos biscainhos assoprados por trombas de água, e as despesas estimadas por ele constavam de " 32 contos de réis e os braços para a sua fabricação em 100 escravos, que seriam empregados na fábrica. Escolheu um lugar para a construção de uma
} 
Não obstante as dificuldades, Kidder narra os bons resultados das ações e do trabalho desenvolvido pelo Major. As peças fundidas foram rodas, cilindros e outros equipamentos destinados aos engenhos das proximidades. O diretor também propôs organizar uma seção para fundição de peças para barcos a vapor e "apesar de todos esses contra-tempos, o Major Bloem persistiu na empresa e conseguiu que a fábrica produzisse, no curto espaço de dois meses, cerca de oito mil dólares em ferro fundidos, como prova de sua capacidade,219.

$\mathrm{Na}$ concepção do viajante norte-americano a raiz dos baixos rendimentos está no fato da fábrica ser um estabelecimento régio, e com isto dependente dos caprichos de agentes governamentais, nem sempre dispostos a investir no ramo da siderurgia, guiandose principalmente por interesses particulares e com ações visando seu próprio favorecimento. Para embasar esta visão se vale da comparação entre Ipanema e os estabelecimentos semelhantes nos Estados Unidos, que contavam com o diferencial de não terem sido patrocinados com capital estatal, decorrendo daí seu sucesso e prosperidade:

\begin{abstract}
"A partir da época em que foram iniciados os trabalhos em Ipanema, centenas de estabelecimentos congêneres surgiram nos Estados Unidos, por iniciativa e com capital particular, a produção global dessas usinas excedeu pelo menos em um milhão de vezes, a da província de São Paulo. E finalmente, depois do que acima dissemos, resta apenas acrescentar que em relatório oficial datado de 1843, perguntava certo ministro, se depois de trinta e quatro anos de experiências, não seria melhor abandonar inteiramente o estabelecimento, pelo menos até que deixasse de constituir fonte de despesas para o erário régio [...] No dia anterior ao de nossa partida, tivemos ocasião de presenciar o processo de fundição, que se assemelha bastante aos das grandes siderurgias norteamericanas; apenas os operários pareciam estranhos, aos olhos de um norte-americano"220.
\end{abstract}

Quando percorreram a Província de São Paulo os viajantes citados tinham como parâmetros o trabalho e produção organizada na formulação capitalista para maximizar e aumentar os lucros. Viajaram dotados de um ideal de aproveitamento dos recursos e matérias-primas que contrastava com a realidade vista. Esta não se enquadrava em seus modelos mentais. Ora são os habitantes negligentes e preguiçosos, ora é a má administração da Coroa dos seus recursos, a conseqüência extraída é sempre a de um quadro de imensas riquezas inexploradas. Conforme Mary Louise Pratt, "Os fracassos da

barragem e edificação da fábrica e designou o 'distrito-mineiro' que foi, afinal, o que se adotou”. José Monteiro Salazar. Araçoiaba \& Ipanema..., op. cit., 87.

${ }^{219}$ Daniel Parish Kidder, Reminiscências de viagem e permanência nas Provincias do Sul do Brasil..., op. cit., p. 251.

${ }_{220}$ Ibidem, p. 252-253. 
vida econômica hispano-americana são diagnosticados nesta literatura não simplesmente como a recusa de trabalhar, mas também, mais especificamente, como o fracasso em racionalizar, especializar e maximizar a produção" 221 .

${ }^{221}$ Mary Louise Pratt. Os olhos do império..., op. cit., p. 261. 


\section{Capítulo 3. A viagem de James Cooley Fletcher e J. J. Aubertin por terras paulistas}

Na segunda metade do século XIX a Província de São Paulo recebeu a visita do pastor metodista norte-americano James Cooley Fletcher ${ }^{222}$ e do britânico J. J. Aubertin ${ }^{223}$, que exerceu o cargo de superintendente da Estrada de Ferro de São Paulo.

Fletcher esteve no Brasil entre fevereiro de 1852 a 1865, com uma breve interrupção ${ }^{224}$. Neste período foi o elo entre a Nova Inglaterra e D. Pedro II, seja mediando

222 "James Cooley Fletcher - Missionário metodista norte-americano. Nasceu em Indianapolis no ano de 1823. A sua missão evangélica no Brasil foi realizada entre os anos de 1851 e 1865, com interrupção entre 1854 e 1855, em que esteve nos Estados Unidos. Fletcher dedicou-se também ao estudo de ciências naturais, tendo, na sua viagem pelo Amazonas, colhido material que enviou ao Prof. Agassiz e de que este se serviu para seus estudos ictiológicos e posteriores observações na mesma região. Durante a sua estada entre nós, em companhia de sua Esposa, conquistou influente círculo de relações, não só no seio da colônia inglesa e norteamericana (foi, por várias vezes, Secretário interino da legação dos Estados Unidos), como entre brasileiros de renome, a começar pelo próprio Imperador. Foi membro do Instituto Histórico e Geográfico Brasileiro. Posteriormente serviu como cônsul de seu país na cidade do Porto, de 1869 a 1873, indo depois, como missionário, para Nápolis. Sabe-se (segundo a publicação biográfica norte-americana 'Who's who', 1890) que em 1877 ainda residia na sua cidade natal, Indianopolis". Edgard Süssekind de Mendonça. Dados Biobiográficos. In.: D. P. Kidder e J. C. Fletcher. O Brasil e os brasileiros (esboço histórico e descritivo). Trad. Elias Dolianiti. São Paulo: Editora Companhia Nacional, 1941, vol. 1, p. IX.

${ }^{223}$ Os dados sobre Aubertin são contraditórios. Durante nossas pesquisas seu nome foi apontado no banco de dados da Library of Congress como sendo John James Aubertin, e por Alice Canabrava como sendo Jean Jacques Aubertin. Sobre sua nacionalidade, encontramos informações que dizem ser J. J. Aubertin inglês, como consta na Grande Enciclopédia Portuguesa e Brasileira, Verbo - Enciclopédia Luso-Brasileira de Cultura, no trabalho de Alice Canabrava e na obra de Gilberto Freyre. Já na Paulistania, edições 53-72, encontramos, na página 19, que J. J. Aubertin é o engenheiro francês Jean Jacques Aubertin (tal informação foi retirada de: www.book.google.com.br). Com base nos dados apresentados nestas obras e no relato de viagem, em nosso trabalho consideramos ser inglesa a nacionalidade de J. J. Aubertin. Alice Canabrava. $O$ algodão em São Paulo..., op. cit.; Gilberto Freyre. Ingleses no Brasil. Aspectos da influência britânica sobre a vida, a paisagem e a cultura do Brasil. Rio de Janeiro: Livraria José Olympio, 1948, p. 88; Grande Enciclopédia... Lisboa; Rio de Janeiro: Editorial Enciclopédia, s/d, p. 704, vol. 3; Verbo - Enciclopédia Luso-Brasileira... Lisboa: Editorial Verbo, 1960, p. 1803, vol. 2; Library of Congress online catalog, em: http://catalog.loc.gov; J. J. Aubertin. Onze dias de viagem na Província de São Paulo..., op. cit.

${ }^{224}$ Edgard Süssekind de Mendonça aponta a interrupção da presença de Fletcher em terras brasileiras de 1854 a 1855. Já Marcus Vinícius de Freitas aponta sua volta aos Estados Unidos "entre 1856 a 1862, [quando] viveu em Newburyport, Massachusetts, de onde visitava freqüentemente Cambridge, onde se tornou amigo de Agassiz e do poeta Longfellow". Tal intervalo de tempo não está de acordo com os apontamentos do próprio Fletcher, que diz em seu relato "Em 1854, regressei por alguns meses aos Estados Unidos. Tendo tido várias vezes ocasião de observar, na minha estada no Brasil, a ignorância aí dominante em relação aos Estados Unidos, e a recíproca ignorância do povo norte-americano em relação ao Brasil [...]". Esta data é reiterada pelo viajante juntamente com a razão de seu retorno em uma carta dirigida ao New York Journal of Commerce e ao Filadelfia Ledger na qual consta: "Rio de Janeiro, 23 de Maio de 1855. 'Srs. Editores ... (Depois de algumas observações preliminares, escrevi o que se segue:) 'O motivo que me animou a empreender esse negócio [Exposição de produtos norte-americanos no Rio de Janeiro] foi simplesmente o bem dos Estados Unidos e do Brasil. [...] Em 1854, em virtude de enfermidade em pessoa de minha família, fui obrigado a deixar subitamente o meu campo de atividade para ir aos Estados Unidos. Aí, passados alguns meses, compreendi que estava obrigado a abandonar a terra da minha adoção. Foi para mim, entretanto, necessário voltar ao Brasil, afim de ultimar os meus negócios. [...] O Srs. Corner \& Sons, de Baltimore, generosamente puseram o seu navio à minha disposição, com passagem grátis. No mês de Março, o belo navio 'Huntingdon' deixou Baltimore levando a minha bagagem. [...] Em Abril, chegamos ao Rio de Janeiro [...]”. D. P. Kidder e J. C. Fletcher. O Brasil e os brasileiros..., op. cit., vol. 1, p. 277 e 277 a 279. Marcus Vinicius de Freitas. Hartt: Expedições pelo Brasil Imperial. 1865-1878. São Paulo: Metalivros, 2001, p. 41. 
a relação entre o Imperador, Luiz Agassiz ${ }^{225}$ e outros naturalistas norte-americanos, ou organizando uma exposição de seiscentos produtos oriundos dos Estados Unidos no grande salão do Museu Nacional, no Rio de Janeiro, que contou com a participação do monarca. Segundo o viajante, sua mostra tinha os "mais altos objetivos em vista do que uma mera difusão de conhecimentos, e uma intensificação do comércio. E, agora, que dois anos se passaram desde a consecução dos meus propósitos, tive a satisfação de saber que novos laços de reciprocidade tinham sido iniciados, que livros escolares haviam sido feitos para o Brasil em estilo americano, e que milhares de dólares foram depois de 1865 empregados na compra dos artigos que expus ${ }^{, 226}$.

Foi também um grande defensor da criação de linhas de navegação direta entre o Brasil e os Estados Unidos, visando melhorar a relação entre os países e aumentar o volume comercializado entre eles. Seu empenho nesta causa foi fortalecido diante do crescimento do lucro auferido pela Inglaterra com a instituição da comunicação direta com os portos brasileiros ${ }^{227}$.

As relações comerciais entre o Brasil e os Estados Unidos intensificaram-se ao longo do oitocentos ${ }^{228}$. Até a década de 1850 o Brasil manteve um saldo favorável na balança comercial entre os dois países, como aponta Luiz Alberto Bandeira: "Até 30 de setembro de 1840, no total de dez anos, os Estados Unidos importavam do Brasil

Edgard Süssekind de Mendonça. Dados Bio-biográficos. In.: D. P. Kidder e J. C. Fletcher. O Brasil e os brasileiros..., op. cit., vol. 1.

${ }^{225}$ Sobre a viagem de Luis Agassiz e sua esposa ver o relato Viagem ao Brasil: 1865-1866. Trad. João Etienne Filho. Belo Horizonte: Ed. Itatiaia; São Paulo: Edusp, 1975.

${ }^{226}$ D. P. Kidder e J. C. Fletcher. O Brasil e os brasileiros..., op. cit., vol. 1, p. 277.

227 "O comércio inglês com o Brasil, desde a fundação de sua primeira linha de vapores em 1850, aumentou as suas exportações de mais de $100 \%$, ao passo que os Estados Unidos exigiram treze anos para fazer o mesmo progresso. O seu comércio total com o Brasil aumenta de $225 \%$, desde a inauguração da primeira linha de vapores. Cada ano, a balança do comércio vem aumentando rapidamente contra nós. Em 1860-1861, os Estados Unidos exportavam para o Brasil, 6.018 contos, ao passo que os Estados Unidos importaram do Brasil 22.547 contos; ou, em outras palavras, um só ano de comércio com o Brasil produz, contra nós, o saldo de 16.528 contos, que temos que pagar a uma pesada taxa de câmbio. A Inglaterra em 1864, vendeu ao Brasil 40.612 contos, e, comprou-lhe apenas 33.079 tornando assim o Brasil seu devedor. Porque esse desastre financeiro contra nós? Os vapores ingleses, a energia e o capital desse país, e a nossa negligência fizeram desse modo progredir o comércio da nossa rival". Ibidem, p. 220-221.

228 "Os dados oficiais, entretanto, não revelam a extensão do comércio entre o Brasil e os Estados Unidos. Linha bastante fluida separava então o negócio legal da pirataria e do contrabando. E nesse particular a navegação americana, que desenvolvera as melhores embarcações da época, as mais velozes, como os clippers, demonstrou elevado padrão de desempenho [...] O abade José Francisco Correia da Serra, ministro de D. João VI em Washington, considerando o corso um instrumento da revolução nas Américas, propusera aos Estados Unidos uma aliança para combatê-lo. O então presidente Monroe recusou. Os Estados Unidos não renunciavam ao corso, tanto na guerra como na paz, e também se negaram a apoiar a Convenção de Paris, para extingui-lo, em 1856. Só depois que irrompeu a guerra civil o governo de Abraham Lincoln (1861-1865) se dispôs a assiná-la, se a sua proibição se estendesse aos Estados Separatistas do Sul. O corso dos confederados causava duras perdas à União, inclusive em águas do Brasil". Luiz Alberto Moniz Bandeira. Presença dos Estados Unidos no Brasil..., op.cit., p. 119-121. 
46.930.648 dólares e exportaram apenas 21.998.822. O saldo favorável ao Brasil foi então de 24.931.826, quase duplicando na década que se iniciava. De 1841 a 1850, a importação de produtos do Brasil pelos Estados Unidos alcançou 69.300.649 dólares, enquanto as suas exportações somavam apenas 27.639.549. O saldo em favor do Brasil aumentou em 41.611.100 dólares. O café que os americanos consumiam numa quantidade cada vez maior, contribuía, decisivamente, para esse desequilíbrio ${ }^{, 229}$.

Tal aspecto não passou despercebido por Fletcher, que o destaca em seu relato:

"Em 1809, o primeiro carregamento foi enviado para os Estados Unidos, e todo o café cultivado no Império nesse ano montava apenas a 30.000 sacas, ao passo que no ano Comercial brasileiro de 1855 exportaram-se 3.256.089 sacas, que trouxeram para o país quase 25.000.000 de dólares. Os Estados Unidos, durante o ano comercial que terminou a 30 de junho de 1856, importaram, de todos os países produtores de café, 235.241.362 libras de grão de café dos quais 180.243.070 libras (isto é, quase três quartos) vieram do Brasil. O seguinte país na lista é a Venezuela, que nos mandou 16.546.166 libras; e o terceiro, Haiti, do qual importamos cerca de 13.500.000 libras. A soma total paga pelos Estados Unidos por café foi 21.514.196 de dólares, dos quais o Brasil recebeu nada menos do que 16.091.714 dólares" ${ }^{\text {"230 }}$.

Internamente os Estados Unidos eram palco de desenvolvimento industrial. Entre 1849 a 1857 “ao longo das fronteiras já traçadas entre o Norte e o Sul. As estradas de ferro substituíram os canais como vias para o transporte de mercadorias e abriram os prados para uma frutuosa colonização. A imigração alcançou novamente um elevado nível e determinou um novo movimento de xenofobia nacionalista em politica" ${ }^{, 231}$. As inovações tecnológicas na agricultura eram reconhecidas internacionalmente, e "em Londres (1851) e em Paris (1855) as máquinas americanas levaram a palma em todos os concursos "232. A cultura do algodão alcançava picos de produção e "a colheita anual aumentou de quarenta milhões para noventa e um milhões de arrobas, mas nem por isso faltavam compradores $^{, 233}$.

Fletcher realizou sua visita às províncias do sul do Brasil, em 1855, e passou por Santos com destino ao Paraná, Santa Catarina e Rio Grande do Sul. De volta a terras paulistas esteve novamente em Santos, seguindo para a cidade de São Paulo, e depois Campinas e Limeira, com destino final à fazenda de Ibicaba do Senador Vergueiro. Sobre

\footnotetext{
${ }^{229}$ Luiz Alberto Moniz Bandeira. Presença dos Estados Unidos no Brasil.., op.cit., p. 119.

${ }^{230}$ D. P. Kidder e J. C. Fletcher. O Brasil e os brasileiros..., op. cit., vol. 2, p. 168.

${ }^{231}$ Samuel Eliot Morison e Henry Steele Commager. História dos Estados Unidos da América..., op. cit., p. 40.

${ }^{232}$ Ibidem, p. 50.

${ }^{233}$ Ibidem, p. 41.
} 
o objetivo da viagem diz: "Enquanto trabalhava pelo bem habilitar-me a ver, por mim próprio, a condição dos milhares de colonos europeus que os empreendedores Vergueiros têm sob suas ordens" 234 . Após visitar o estabelecimento retornou ao porto santista e no dia 6 de julho embarcou no paquete "Paraense" rumo ao Rio de Janeiro.

Dez anos após o pastor metodista ter deixado as terras paulistas, o inglês J. J. Aubertin percorreu a Província de São Paulo. Monica Charlot e Roland Marx apontam haver na Inglaterra deste período um conjunto de valores, melhor qualificado como "puritano", que percebemos no filtro econômico utilitarista do viajante. Nele figurava a ânsia em poupar, a dedicação ao trabalho, o domínio do espírito do progresso, a sede de saber com um entusiasmo crescente por toda inovação técnica e a pobreza era freqüentemente ligada ao vício, à preguiça e aos excessos ${ }^{235}$.

Aubertin percorreu a Província na companhia dos norte-americanos sulistas Dr. Gaston, Dr. Shaw e Major Mereweather, que analisavam as condições de diferentes regiões paulistas para a imigração norte-americana. No seu relato discorre tanto sobre as impressões deles como as potencialidades dos locais visitados para a cultura algodoeira e a inserção de São Paulo no mercado internacional.

A viagem estava relacionada a uma série de acontecimentos internacionais. Nos Estados Unidos o período de prosperidade das décadas de 1840 e 50 foi seguido pela Guerra de Secessão (1861-1865). A causa principal do conflito foram as ações dos estados do norte contra a escravidão, afetando diretamente os estados do baixo sul ${ }^{236}$.

Segundo Morison e Commager as conseqüências da guerra foram distintas para os estados do norte e do sul. Sobre os primeiros apontam: "Apesar dos quatro anos de guerra, os recursos do Norte não pareciam ter sido prejudicados. A população e a riqueza tinham crescido; a produção das fábricas e granjas era maior que nunca. A dívida nacional orçava por três bilhões de dólares, mas ninguém duvidava da solvência do governo. Havia mais

\footnotetext{
${ }^{234}$ D. P. Kidder e J. C. Fletcher. O Brasil e os brasileiros..., op. cit., vol. 2, p. 9.

${ }^{235}$ Monica Charlot e Roland Marx. A sociedade "dual" por excelência. In.: Monica Charlot e Roland Marx (orgs.). Londres: 1851-1901: a Era Vitoriana ou o triunfo das desigualdades. Rio de Janeiro: Jorge Zahar Ed., 1993, p. 16.

${ }^{236}$ Utilizamos os termos "Estados do norte", para os defensores da união nacional e do fim do sistema escravista, e "Estados do sul", partidários da separação entre os estados e a favor da escravidão, tal como encontramos nas obras à respeito da Guerra da Secessão, mas como apontam Morison e Commager "durante toda a Guerra Civil não ficaram delimitadas de uma maneira absolutamente clara as linhas entre os estados que se separaram e os que permaneceram na União". Samuel Eliot Morison e Henry Steele Commager. História dos Estados Unidos da América..., op.cit., p. 79.
} 
dinheiro em circulação que em qualquer outra época da nossa história, e o recenseamento de 1870 revelou que a riqueza do Norte per capita havia duplicado em dez anos”,237.

Para os estados do sul os resultados foram catastróficos e trouxeram a implantação do modelo industrial e do trabalho livre, oriundos do norte, com a hegemonia dos seus padrões em âmbito nacional. Sua produção algodoeira foi destroçada e a agricultura somente voltou ao seu ritmo anterior à guerra no final da década de 1880 . O valor da propriedade teve uma queda de $48 \%$. Toda a indústria manufatureira foi arrasada. $\mathrm{O}$ sistema de transportes estava quase todo destruído e a maior parte das companhias do ramo faliram $^{238}$. Durante os anos da guerra civil houve americanos sulistas que deserdaram da luta para manter suas terras, outros fugiram para a Inglaterra, México e para o Brasil, houve também aqueles que seguiram para o Oeste dos Estados Unidos ou se estabeleceram nas cidades em busca de trabalho ${ }^{239}$. Relacionada a este quadro estava a vinda dos Drs. Gaston e Shaw e o Major Mereweather à São Paulo.

As conseqüências da Guerra Civil nos Estados Unidos ultrapassaram os limites do seu território. Com a queda abrupta da produção algodoeira norte-americana a Inglaterra perdeu seu maior fornecedor, assim como outros países europeus, o que configurava um grande entrave para a sua produção industrial têxtil, que no período detinha a hegemonia tanto como compradora de matéria-prima como exportadora dos artigos manufaturados.

Para evitar um colapso maior, em várias partes do mundo os ingleses se esforçaram para expandir a lavoura algodoeira, visando suprir a escassez da matéria-prima. Os dados da tabela 6 abaixo apontam para os resultados do empenho deles: o crescimento da exportação brasileira e de outros países para a Inglaterra. Nota-se também, a queda do volume comercializado pelos Estados Unidos no período da Guerra Civil e o seu aumento após o término do conflito.

\footnotetext{
${ }^{237}$ Samuel Eliot Morison e Henry Steele Commager. História dos Estados Unidos da América..., op.cit., p. 174.

${ }^{238}$ Ibidem, p. 178-179.

${ }^{239}$ Ibidem, p. 170.
} 
TABELA 6 - Importação de algodão na Inglaterra (fardos)

\begin{tabular}{|l|l|l|l|l|}
\hline \multicolumn{1}{|c|}{ Ano } & \multicolumn{1}{c|}{ E.U. } & \multicolumn{1}{c|}{ Brasil } & \multicolumn{1}{c|}{ Egito } & \multicolumn{1}{c|}{ Outros países } \\
\hline & & & & \\
\hline 1860 & 2.512 .582 & 100.157 & 106.880 & 557.247 \\
\hline 1861 & 1.760 .002 & 94.825 & 93.425 & 946.850 \\
\hline 1862 & 61.604 & 113.903 & 125.276 & 938.464 \\
\hline 1863 & 108.193 & 112.383 & 168.636 & 694.134 \\
\hline 1864 & 155.741 & 167.141 & 202.466 & 1.512 .385 \\
\hline 1865 & 374.661 & 274.170 & 268.811 & 1.305 .120 \\
\hline 1866 & 955.473 & 334.989 & 137.601 & 1.652 .682 \\
\hline
\end{tabular}

FONTE: O Auxiliador, 1869, p. 90. apud. Alice P. Canabrava. O algodão em São Paulo: 1861-1875. 2. ed. São Paulo: Ed. T. A. Queiroz, 1984, p. 7.

NOTA: "Em 1861, as fábricas inglesas que há dois estavam produzindo acima de suas necessidades, possuíam estoques que representavam mais que o dobro de suas necessidades normais. [...] A paralisação das exportações americanas, na segunda metade do ano de 1861, quando se tornou efetivo o bloqueio dos estados confederados, vinha afetar, portanto, um país em plena superprodução de tecidos de algodão". Alice P. Canabrava. O algodão em São Paulo..., op. cit., p. 4-5.

A busca dos ingleses por outros fornecedores se dava desde 1857, quando na Inglaterra foi fundada a Associação para o Suprimento do Algodão de Manchester (Manchester Cotton Supply Association) voltada para o desenvolvimento da cultura algodoeira na Índia. Quando teve início a Guerra Civil norte-americana, os seus objetivos ultrapassaram os territórios indianos, atingindo o Brasil. Aubertin era seu correspondente para a implantação e expansão do cultivo do algodão na Província de São Paulo. Seus esforços lhe renderam em 1869 uma medalha de ouro desta instituição e do governo brasileiro recebeu o hábito da Imperial Ordem da Rosa ${ }^{240}$.

Alice Canabrava data do início da década de 1860 os esforços de Aubertin no desenvolvimento da cultura algodoeira ${ }^{241}$, quando “em passeio pelos arredores da capital paulista, em abril de 1861, o superintendente inglês colheu casualmente, na várzea do rio Tietê, de uma árvore aparentemente selvagem, que vegetava em terreno abandonado, algumas cápsulas de algodão. Informado de que a cultura do algodão, próspera no passado, fora abandonada, se bem que ainda subsistisse em espaços muito restritos da Província, e tendo em vista a crise dos Estados Unidos, interessou-se Aubertin em que fosse 'por alguns modos renovada e mais cientificamente desenvolvida esta cultivação do

\footnotetext{
${ }^{240}$ Alice P. Canabrava. O algodão em São Paulo..., op. cit., p. 14.

${ }^{241}$ J. J. Aubertin escreve sobre o início de suas atividades na Província de São Paulo: "Com todas as minhas esperanças, convicções e insistência a respeito desta cultura [do algodão], não sendo profeta nunca podia adivinhar quando tomei o meu primeiro passo em Abril de 1861, que a realização da primeira verdadeira colheita coincidisse com uma inesperada emigração da sua pátria, e com a sua visita de exploração a esta província...”. J. J. Aubertin. Onze dias de viagem na Província de São Paulo com os Srs. Americanos Drs. Gaston e Shaw, e o Major Mereweather. 1865. Carta dirigida ao Illm. e Exm. Sr. Barão de Piracicaba. São Paulo: Typ. Allemã de H. Schroeder, 1866, p. 36.
} 
algodão'. Enviou, pois, para Londres, em 20 de abril de 1861, as fibras que por acaso havia colhido [...] No início do mês de junho do mesmo ano, a Associação para o Suprimento do Algodão de Manchester manifestava-se favoravelmente quanto à amostra recebida e, em atenção ao pedido de Aubertin, remetia-lhe imediatamente, [...] dois quintais de semente de algodão e um descaroçador de algodão ${ }^{, 242}$.

Em São Paulo a cultura do algodão era incentivada tanto pela instituição inglesa como pelas autoridades públicas do Império e da Província. Alguns entraves limitaram a sua expansão. Grande parte dos lavradores consideravam-na provisória e preferiam investir no açúcar e no café; faltavam maquinários para descaroçar e enfardar a produção; os meios de transporte eram precários, as sementes escassas e não havia os conhecimentos técnicos para o cuidado das plantações e combate às pragas.

Apesar das limitações, durante os anos da guerra civil americana a produção algodoeira paulista teve grande aumento, como podemos perceber na tabela 7 abaixo. Todavia, quando a agricultura norte-americana voltou a se desenvolver e operar com capacidade semelhante à anterior ao conflito, reocupando sua posição no comércio internacional a lavoura paulista, limitada por uma série de fatores e desenvolvida em uma base frágil, passou a ser dependente dos resultados dessa produção. Com isso, "o primeiro aumento ponderável das colheitas norte-americanas, registrado em 1867-68, repercutindo no mercado europeu com um novo abaixamento de preço, teve com [sic] resultado a primeira crise da lavoura algodoeira da Província, ${ }^{, 243}$. Desta forma, o crescimento e o declínio da lavoura algodoeira paulista esteve condicionada à procura inglesa desta matéria-prima e às limitações da agricultura norte-americana decorrentes dos anos de guerra civil.

\footnotetext{
${ }^{242}$ Alice P. Canabrava. O algodão em São Paulo..., op. cit., p. 9-10.

${ }^{243}$ Ibidem, p. 232.
} 
TABELA 7 - Exportação de algodão (em Kgs)

\begin{tabular}{|l|l|l|l|}
\hline \multicolumn{1}{|c|}{ Ano } & \multicolumn{1}{|c|}{ São Paulo (1) } & \multicolumn{1}{|c|}{ Brasil (2) } & Estados Unidos (3) \\
\hline & & & \\
\hline 1861 & & & 2.342 .099 \\
\hline 1862 & 1.305 & & 5.224 .576 \\
\hline 1863 & 5.040 & 19.671 .672 & 5.506 .341 \\
\hline 1864 & 106.605 & 25.358 .635 & 4.081 .686 \\
\hline 1865 & 2.898 .645 & 42.636 .144 & 298.547 .949 \\
\hline 1866 & 3.344 .898 & 42.636 .144 & 321.619 .376 \\
\hline 1867 & 8.185 .973 & 37.728 .762 & 344.807 .364 \\
\hline 1868 & 7.176 .255 & 47.669 .584 & 298.388 .023 \\
\hline 1869 & 6.142 .228 & 41.404 .470 & 456.079 .600 \\
\hline 1870 & 5.475 .682 & 43.024 .065 & 670.626 .593 \\
\hline 1871 & 10.204 .610 & 46.519 .446 & 418.731 .794 \\
\hline 1872 & 9.286 .250 & 83.543 .317 & 566.876 .875 \\
\hline 1873 & 9.283 .258 & 44.618 .060 & 615.529 .453 \\
\hline 1874 & 6.127 .174 & 54.474 .126 & 574.569 .875 \\
\hline 1875 & 4.074 .965 & & 696.988 .792 \\
\hline 1876 & 2.173 .946 & & 651.504 .460 \\
\hline 1877 & 643.074 & & 733.652 .378 \\
\hline
\end{tabular}

FONTE: (1) Synopsis da exportação total da Província de São Paulo, pelo porto de Santos, nos últimos quinze exercicios, e estes comparados por quinquennios. A. de Brito - Relatório, 1881, s.p. (2) O estado da lavoura. Diário de S. Paulo, 21-5-1874, p. 2. (3) J. A. B. Scherer. Cotton as World Power, p. 420. apud. Alice P. Canabrava. O algodão em São Paulo: 1861-1875. 2. ed. São Paulo: Ed. T. A. Queiroz, 1984, p. 301. NOTA: “A elevada exportação de algodão em 1871-72, que atinge 10.204 .610 kgs., é explicada pela retenção das colheitas de 1870, que só começaram a ser vendidas no ano seguinte. Parte da colheita anterior havia ficado armazenada em Santos, segura pelos especuladores que procuraram taxar o produto por preços que não lograram alcançar. [...] Em conseqüência, registra-se em 1870-71, de um modo geral, grande desinteresse pela cultura do algodão, não só porque os preços não animavam os lavradores, como porque contavam para a exportação de 1871 com o saldo de 1870". Alice P. Canabrava. O algodão em São Paulo.., op. cit., p. 236237.

A busca por regiões capazes de fornecer algodão para a indústria têxtil britânica direcionou a viagem de Aubertin quando esteve nas terras paulistas. Suas observações versam, além desta temática sobre as necessidades de melhores caminhos para o escoamento da produção e a comunicação direta entre o porto santista e o mercado internacional, porque para o inglês "tendo a província chamado o mundo para vir comerciar em Santos, já recebeu uma resposta pelas ondas do Atlântico. Já foi a luva atirada, nem deve ser recusado o repto" ${ }^{, 244}$.

Como aponta, sua motivação ao realizar a viagem foi "não menos por simpatia para com a antecipada imigração americana, como também pelo desejo de visitar em sua companhia algumas plantações de algodão, e tirar algumas instruções de sua experiência

\footnotetext{
${ }^{244}$ J. J. Aubertin. Onze dias de viagem na Província de São Paulo..., op. cit., p. 32.
} 
prática, a respeito de uma cultura que, sendo hoje estabelecida na província, não pode deixar de influi-los cabalmente na resolução que definitivamente tenham que tomar,"245.

${ }^{245}$ J. J. Aubertin. Onze dias de viagem na Província de São Paulo..., op. cit., p. 4. 


\section{$\underline{\text { 3.1. A viagem de Fletcher por São Paulo }}$}

O relato O Brasil e os brasileiros (1857) constitui a adição dos registros de Fletcher relativos a sua viagem à Província de São Paulo, em junho de 1855, aos dados apresentados por Daniel Kidder em Reminiscências de viagem (1845), fruto da sua estada nesta região em 1839. Os dois pastores no decorrer da obra apontam claramente quando é um ou outro que escreve. Desta forma, no presente sub-capítulo teremos como foco as informações apresentadas por Fletcher, em vista que as passagens elaboradas por Kidder já foram analisadas.

Fletcher, como pastor metodista, ao percorrer as terras paulistas intencionava difundir os ensinamentos bíblicos nos locais onde passava, ofertando exemplares da Bíblia àqueles que conhecia, e, também visitou a fazenda de Ibicaba do Senador Vergueiro, em Limeira, a fim de conhecer as condições dos colonos europeus contratados pela Vergueiro \& Filhos.

Com tais fins deixou o Rio de Janeiro em navio e seguiu para Limeira, passando por Ubatuba, onde cuidou da correspondência e adquiriu laranjas, e São Sebastião considerada "bem cultivada e algum [sic] tanto populosa"246. Ao chegar à Santos destaca, tal como os outros viajantes, "o porto da florescente província de São Paulo"247; sua passagem foi rápida, dois dias, em que desembarcou sua bagagem e visitou a casa comercial do Sr. José Vergueiro, porém não conversou com qualquer membro da família pois todos estavam ausentes. Neste dia jantou no hotel do Sr. Francisco na companhia de mercadores, médicos, alguns funcionários do governo e um coronel. Pernoitou no vapor e no dia seguinte retornou ao armazém onde encontrou o filho mais novo do Senador. Às 20:00 deixou Santos e seguiu em direção às províncias do sul.

Ao retornar de Santa Catarina desembarcou novamente em Santos, onde permaneceu por pouco tempo porque "tencionava partir para o interior no mesmo dia de minha chegada"248. De Santos seguiu por Cubatão para a cidade de São Paulo. Este caminho estava sendo melhorado para diminuir sua inclinação e engenheiros ingleses projetavam uma estrada para o interior. Segundo o viajante, esta obra era "a grande esperança dos Vergueiros [e] que não está longe o dia em que o café de Campinas, Limeira

\footnotetext{
${ }^{246}$ D. P. Kidder e J. C. Fletcher. O Brasil e os brasileiros..., op. cit., vol. 2, p. 7.

${ }^{247}$ Ibidem, p. 8.

${ }^{248}$ Ibidem, p. 57.
} 
e Itu, venha a ser trazido sobre rodas até Santos"249. Após chegar ao cume da montanha, às dez horas almoçou no hotel do Sr. Lefevre, francês de Roussillon ${ }^{250}$.

Aponta que durante seu percurso encontrou constantemente tropas de mulas carregadas de café com destino à Santos e outras no trajeto inverso, isto é, do litoral santista para o interior paulista. Mas não só a produção cafeeira era transportada no lombo de mula, conforme afirma, "eles geralmente carregam açúcar e outros produtos agrícolas, transportando, de volta, sal, trigo e qualquer variedade de mercadoria importada. Fui informado que, anualmente, duzentas mil mulas chegam com suas cargas a Santos. Um senhor, que durante muitos anos empregou esses meios de condução no transporte de mercadorias, disse que raras vezes ou nunca, soubera de um artigo que não chegara ao seu destino ${ }^{, 251}$.

Caio Prado Júnior destaca a ligação entre Santos e São Paulo e a data de antes do século XIX. Em suas palavras: "Desde logo, há entre estes dois núcleos, S. Paulo e Santos, uma ação recíproca permanente, e a importância de um se projeta fatalmente sobre o outro. Ambos se completam, e no sistema econômico da capitania satisfazem cada qual uma destas funções conexas e inseparavelmente ligadas: centro natural do planalto $e$ porto maritimo" ${ }^{, 252}$.

Seguindo caminho, o viajante no crepúsculo, avistou a cidade de São Paulo e sobre esta paisagem escreve: "Sua posição elevada num pequeno planalto que vai se alteando a partir da planície, suas numerosas torres e campanários e velhos edifícios conventuais, dão-lhe um aspecto muito mais imponente do que o de uma cidade de maior população ${ }^{, 253}$. Antes de chegar à cidade passou pelo Ipiranga, e criticou a ausência de um monumento digno de bronze ou mármore mais durável em comemoração a um acontecimento tão importante para o país.

\footnotetext{
${ }^{249}$ D. P. Kidder e J. C. Fletcher. O Brasil e os brasileiros..., op. cit., vol. 2, p. 62.

250 "Só em torno de 1854 parece que começaram a aparecer os primeiros hotéis 'que davam hospedagem' sem carta de recomendação: o Hotel Paulistano, de Adolfo Dusser, na rua de São Bento esquina da ladeira do Açu; o Hotel do Comércio, de Hilário Magro, na rua da Fundição (Floriano Peixoto) esquina do pátio do Colégio, pegado ao Teatro da Ópera; o Hotel da Providência, de Madame Lagarde, com bilhares, na rua do Comércio; e o melhor de todos eles, o Hotel Universal, do francês Lefebre, também no pátio do Colégio, onde começaram a se fazer ceias alegres de aristocratas. Quase da mesma época era o Hotel das Quatro Estações, que alguns anos depois, sob a direção de José Maragliano, passaria a se chamar Hotel da Itália e mais tarde Hotel da França". Ernani da Silva Bruno. História e tradições da Cidade de São Paulo. Burgo de estudantes (1828-1872). Rio de Janeiro: Livraria José Olympio Editora, 1954, vol. 2, p. 693-694.

${ }^{251}$ D. P. Kidder e J. C. Fletcher. O Brasil e os brasileiros..., op. cit., vol. 2, p. 65.

${ }^{252}$ Caio Prado Junior. O fator geográfico na formação e no desenvolvimento da Cidade de São Paulo. In.: Caio Prado Junior. Evolução política do Brasil e outros estudos. 5. ed. São Paulo: Editora Brasiliense, 1966,

p. 103.
${ }^{253}$ D. P. Kidder e J. C. Fletcher. O Brasil e os brasileiros..., op. cit., vol. 2, p. 67.
} 
De noite, após atravessar o rio Tietê chegou à cidade paulista. Sua primeira reação foi a certeza de se encontrar ao sul do trópico de Capricórnio, devido à vegetação e ao frio. Encontrou alguns estudantes do curso de direito que o levaram ao hotel do Senhor C., e no trajeto conversou com eles sobre a desnecessária existência de corporações de monges e frades em um novo país como o Brasil.

Fletcher considera sua entrada em São Paulo diversa da de Mawe, feita quase cinqüenta anos antes: "Da minha parte, entrei a cavalo na cidade e fui para o hotel da mesma forma como teria feito em Boston, Liverpool ou Genebra" ${ }^{254}$. E passa a citar o assombro dos habitantes, em 1808, ao verem um inglês, inclusive, as crianças naquela ocasião contavam os dedos de Mawe e chegaram a espantosa conclusão de que ele tinha o mesmo número de dedos nas mãos que elas ${ }^{255}$. Tal situação se deu porque a Província de São Paulo em meados do oitocentos assumiu ares cosmopolitas e passava por transformações e mudanças, tendo como foco a modernização e a reformulação das cidades, com maior ou menor intensidade, dentro dos parâmetros europeus de civilidade. Os estrangeiros se faziam presente em todo o território provincial.

As mudanças nas feições de São Paulo já estavam em andamento desde a passagem de Mawe por essas paragens. Como aponta Sérgio Buarque de Holanda: "Baste-nos lembrar, para um exemplo, como já em 1810 o comércio inglês, esse poderoso, talvez o mais poderoso, agente de 'descolonização' do Brasil, descolonização, é claro, com referência ao passado português, começa a tomar pé em S. Paulo. De fato, em uma circular de 10 de novembro desse ano, endereçada aos capitães-mores das vilas mais importantes, o General Franca e Horta pode aludir aos diferentes negociantes britânicos que já montaram casas comerciais na cidade e anunciar que outros se acham prestes a chegar com o mesmo fito ${ }^{, 256}$.

\footnotetext{
${ }^{254}$ D. P. Kidder e J. C. Fletcher. O Brasil e os brasileiros..., op. cit., vol. 2, p. 69.

255 "A nossa presença em São Paulo excitou de maneira indescritível a curiosidade do povo, que parecia nunca ter visto ingleses, até então; as próprias crianças demonstravam o seu espanto, algumas fugindo, outras contando os nossos dedos, constatando, admiradas, termos o mesmo número que elas. Muitos dos bons cidadãos convidaram-nos a ir às suas casas e mandaram chamar os amigos para que nos viessem ver. Como a casa que ocupáramos era muito grande, vimo-nos, freqüentemente, cercados por uma multidão de jovens de ambos os sexos, que vinham até a porta para ver como comíamos e bebíamos. Sentimo-nos gratos ao verificar que esta admiração geral converteu-se num sentimento mais sociável; encontramos bom acolhimento em toda a parte e fomos convidados, várias vezes, para jantar com os habitantes. Nas festas públicas e nos bailes do governo encontramos novidade e prazer; novidade, porque fomos muito melhor recebidos do que nas colônias espanholas, e prazer, por estarmos num meio mais requintado e cortês". John Mawe. Viagens ao interior do Brasil..., op. cit., p. 71.

${ }^{256}$ Sérgio Buarque de Holanda. São Paulo. In.: Sérgio Buarque de Holanda (org.). História Geral da Civilização Brasileira. O Brasil monárquico: dispersão e unidade..., op. cit., p. 429.
} 
No início do século XIX houve a formulação de propostas para melhorar e modernizar a Província de São Paulo, e na segunda metade deste século foram tomadas medidas efetivas, e a região passou a contar com maciços investimentos econômicos, com a fundação de companhias e corporações. Para Eudes Campos "vários são indícios desta nova fase: a proibição efetiva do tráfico de escravos, que deu um golpe à instituição escravocrática; a instituição de novos sistemas de trabalho na grande lavoura do café que avançava pelo Oeste paulista, iniciados em 1848 com a colônia de parceria; as tentativas de organização do Banco do Brasil e a conseqüente organização de uma rede bancária; a aprovação do Código Comercial, que, entre outras coisas, previa a formação de sociedades anônimas, e a Lei de Terras ${ }^{257}$, que introduziu novidades no sistema de terras brasileiro, buscando garantir o surgimento de um proletário rural que viesse trabalhar nas fazendas do país. [...] A mentalidade conservadora estaria sendo continuadamente desafiada por aqueles que buscavam introduzir a idéia de cidade eficiente. Setores das camadas superiores da população paulista, impregnados agora pela visão mecanicista do mundo, própria do progressismo burguês, com empenho e ironia, reivindicavam melhorias urbanas, sobretudo nas páginas da imprensa diária ${ }^{, 258}$.

Sobre a cidade Fletcher destaca sua localização, as ruas consideradas estreitas e sem planejamento, as calçadas também estreitas e sua pavimentação, os edifícios, a disseminada utilização da taipa para a construção de casas e como se dava este processo de edificação.

Em carta a um amigo no Rio de Janeiro, datada de 26 de junho de 1855, escreve gostar do seu aspecto, e a causa do seu respeito "não se originava do tamanho da cidade, nem do seu pitoresco, mas de se notar um ar mais intelectual e menos comercial em seus habitantes do que eu vira em outra qualquer parte do Brasil. Não se ouvia a palavra dinheiro constantemente soando aos ouvidos, como no Rio de Janeiro. Há nada menos de quinhentos estudantes de direito na escola que ai funciona, cujo aspecto realmente evoca as escolas de direito dinamarquesas da Universidade de Harvard (sic) e dos estudantes de Heidelberg ${ }^{, 259}$.

\footnotetext{
${ }^{257}$ A Lei de Terras data de 1850, sendo elaborado um regulamento para sua aplicação em 1854. Sobre o tema ver Raquel Glezer. Chão de terra e outros ensaios sobre São Paulo. São Paulo: Alameda, 2007.

${ }^{258}$ Eudes Campos. São Paulo: desenvolvimento urbano e arquitetura sob o Império. In.: Paula Porta (org.). História da Cidade de São Paulo: a cidade no Império. São Paulo: Paz e Terra, 2004, vol. 2, p. 201. [Itálico do autor].

${ }^{259}$ D. P. Kidder e J. C. Fletcher. O Brasil e os brasileiros..., op. cit., vol. 2, p. 72.

"Na relação das cidades imperiais por população ou significado econômico, a cidade de São Paulo sempre estava abaixo de outras capitais de província. Contudo, poucas cidades do Império receberam a honra de
} 
Tal como Kidder, trata da história de São Paulo e dos esforços missionários em terras paulistas, inclusive citando longamente trechos do relato de 1845 do seu conterrâneo. Sobre a ação evangelizadora, diz encontrar a mesma boa vontade apontada por ele em todas as camadas da sociedade na recepção aos ensinamentos bíblicos.

Para melhor visualizar a cidade paulista visitada por Fletcher, nas páginas seguintes temos o mapa da "Vida Intelectual e Espiritual na Cidade de São Paulo - 1837-1878", elaborado por Ederson Matos para o trabalho de Marisa Deaecto, no qual podemos localizar além da Faculdade de Direito, as igrejas, edifícios públicos e religiosos, teatros, associações, sociedades, instituições de ensino, bibliotecas e repúblicas ${ }^{260}$.

serem "Cidades Imperiais". A cidade de São Paulo recebeu esse título e isso foi transformado em fato de distinção. Os motivos da concessão podem ter sido vários: quer por ter sido o local da Proclamação da Independência (nas margens do riacho do Ipiranga, hoje poluído e mal tratado); porque os Andradas eram da Capitania de São Paulo e eles tiveram peso e influência no processo de Independência, ou por influência da Marquesa de Santos. Outro elemento foi a Academia de Direito. Na Assembléia Constituinte de 1823 os deputados discutiram a necessidade de formar quadros administrativos, que substituíssem os que vinham da colonização, para o novo Estado. O modo tradicional metropolitano de administrar incluía três figuras: o militar, o clérigo e o letrado. As escolas já existiam, trazidas por D. João, mas eram para a formação de alguns elementos especializados, restritivas, limitadas. O clero era formado pela Igreja. Os letrados geralmente eram formados em Direito, em Coimbra. Havia a necessidade de existir pelo menos um curso de Direito. Duas cidade foram escolhidas para ter cursos de Direito: Olinda e São Paulo. A cidade de Olinda foi escolhida pelo seu papel tradicional, pelo fato de ter na região de Recife, que é próxima, um cruzamento de rotas que ligam o Nordeste e o Norte. E a cidade de São Paulo, que também controlava um cruzamento de rotas na Região Sul e porque era apropriada para estudantes, pois 'nela não havia nada que os pudesse pertubar na sua fundamental tarefa de estudar': não havia teatro, não havia diversões, nada. O que poderiam os estudantes fazer na cidade? Apenas estudar...". Raquel Glezer. Chão de terra..., op. cit., p. 177-178. Richard Morse credita às feições acadêmicas de São Paulo a maior capacidade de controlar as influências externas. Em suas palavras: "Com referência aos meados do século, é o da consciência que a cidade ia tomando de novas possibilidades para a vida pessoal e social. A palavra 'consciência' é importante. Pois São Paulo - como cidade acadêmica, capital da Província, centro econômico e diocesano - estava em condições de passar por um processo de 'abertura' mais controlado e seletivo que o das pequenas comunidades mestiças das Américas, contra as quais se chocaram subitamente os padrões das grandes cidades". Richard Morse. Formação histórica de São Paulo (de comunidade à metrópole). São Paulo: Difusão Européia do Livro, 1970, p. 142.

${ }^{260}$ Marisa Midori Deaecto. No Império das Letras..., op. cit., p. 197-198. 
MAPA 5 - "Mapa da Vida Intelectual e Espiritual na Cidade de São Paulo (18371878)"

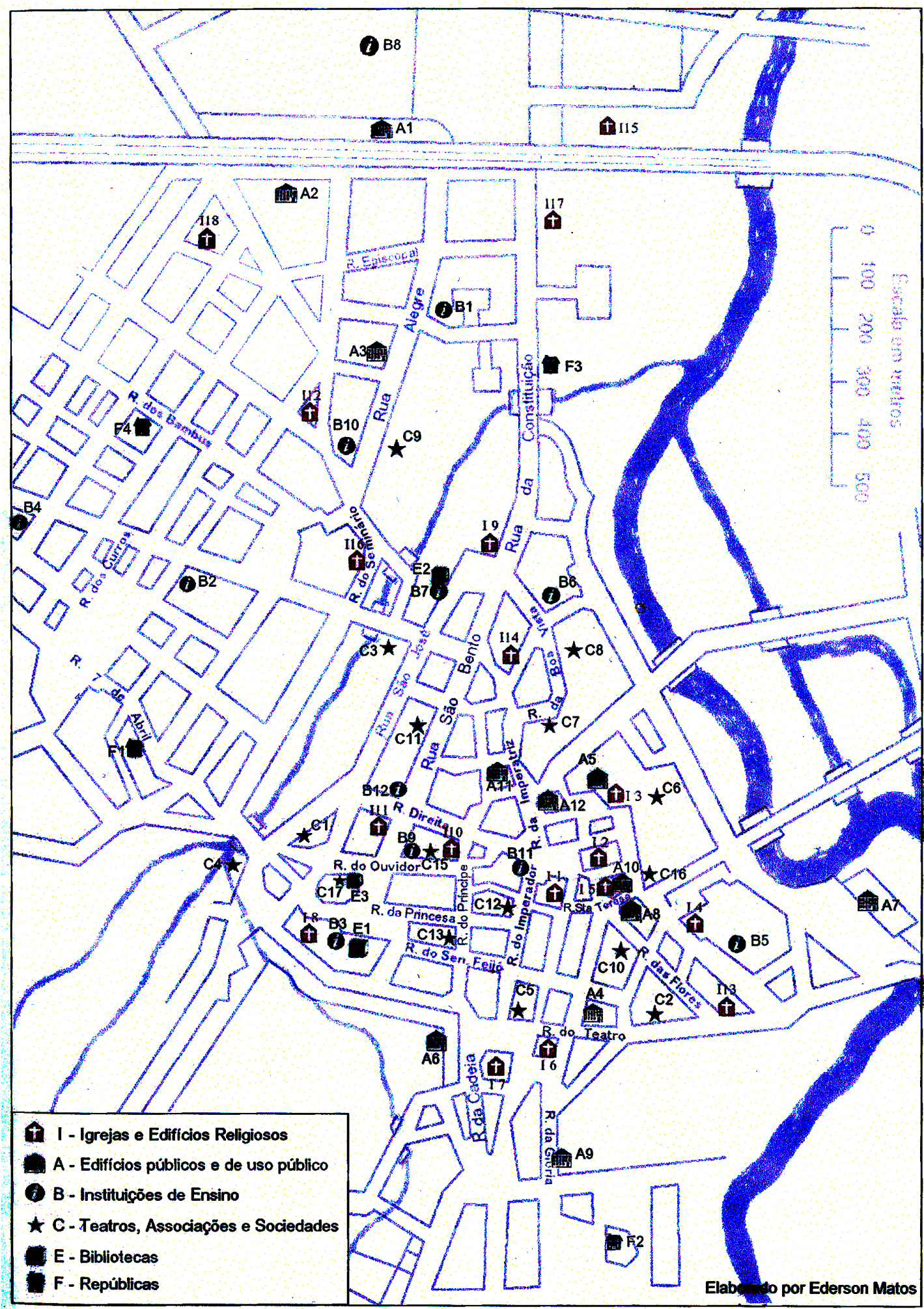

FONTE: Marisa Midori Deaecto. No Império das Letras: circulação e consumo de livros na São Paulo oitocentista. Tese de doutorado. Departamento de História/Faculdade de Filosofia, Letras e Ciências Humanas. São Paulo, 2005, p. 197-198. 


\section{LEGENDA}

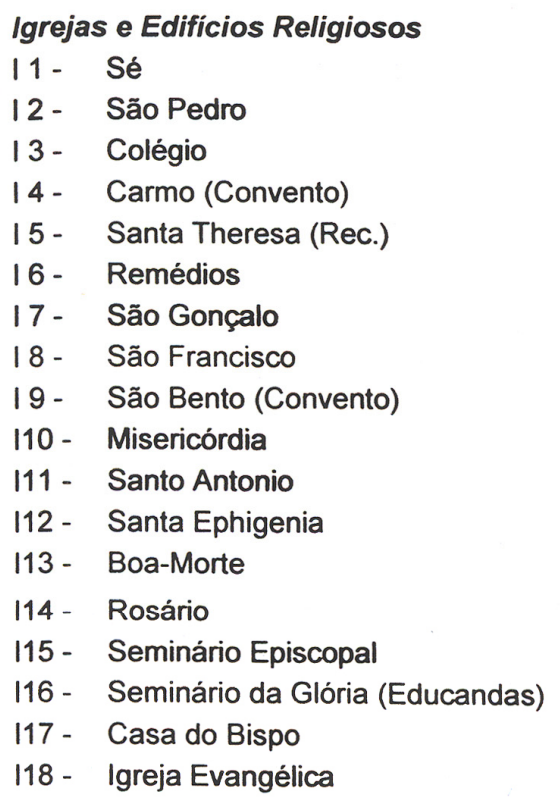

Teatros, Associações e Sociedades

$\begin{array}{ll}\text { C1 - } & \text { Loja Maçônica América } \\ \text { C2 - } & \text { Loja Maçônica Amizade } \\ \text { C3 - } & \text { Loja Maçônica Piratininga } \\ \text { C4 - } & \text { Loja Maçônica } 7 \text { de Setembro } \\ \text { C5 - } & \text { Teatro São Jose } \\ \text { C6 - } & \text { Teatro da Ópera } \\ \text { C7 - } & \text { Teatro Provisório } \\ \text { C8 - } & \text { Arcadia Paulista } \\ \text { C9 - } & \text { Agricultura, comércio e artes } \\ \text { C10- } & \text { Sociedade "Ensaio Philosophico Paulistano" } \\ \text { C11- } & \text { Sociedade "Atheneu Paulistano" } \\ \text { C12- } & \text { Sociedade "Proteção aos Artistas" } \\ \text { C13- } & \text { Teatrinho da Batuira } \\ \text { C14- } & \text { "Club Enterpe Commercial" } \\ \text { C15- } & \text { Taberna d'O Corvo } \\ \text { C16- } & \text { Sociedade "Concordia Paulistana" } \\ \text { C17- } & \text { Sociedade Germânia }\end{array}$

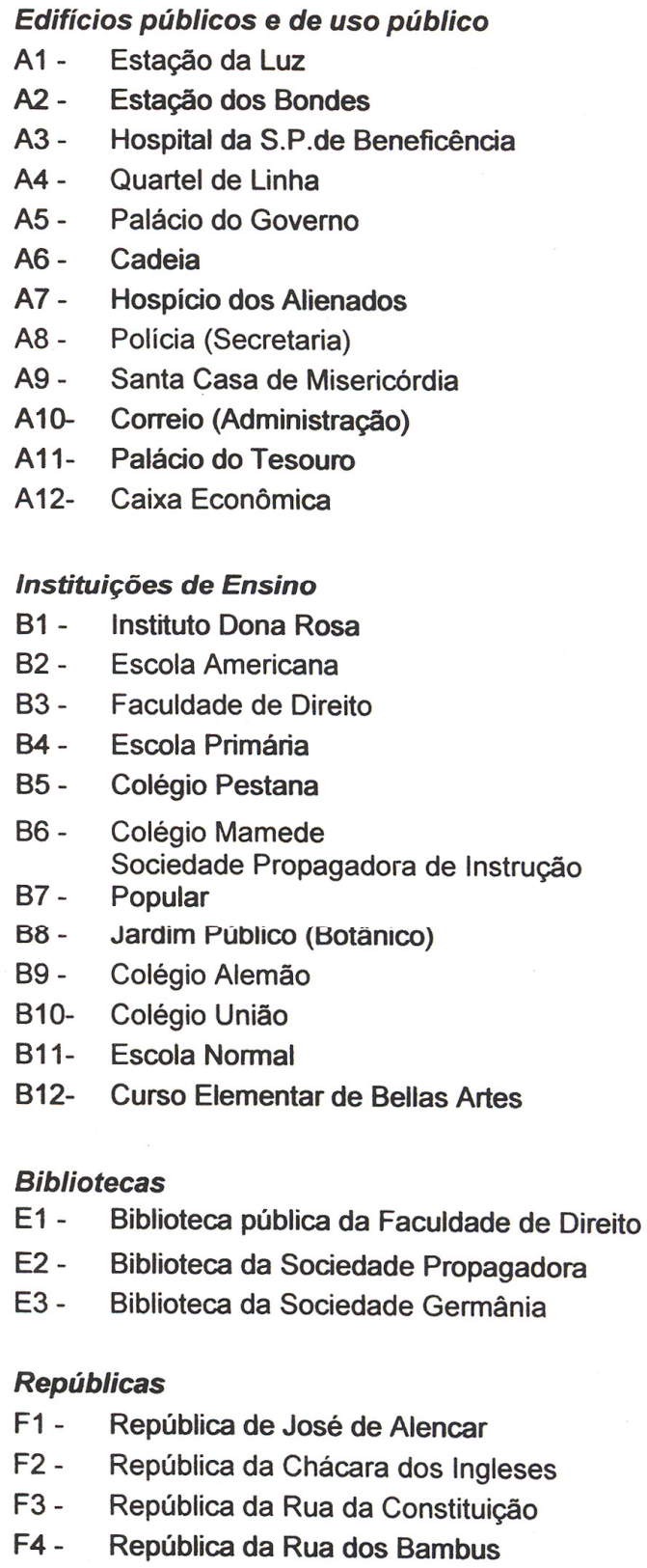

No dia 21 de junho deixou a cidade e partiu para Limeira, com destino à fazenda de Ibicaba do Senador Vergueiro. A paisagem vista e os caminhos trilhados são resumidos nas seguintes palavras: "Percorremos, tão rapidamente quanto possível, uma bela região da

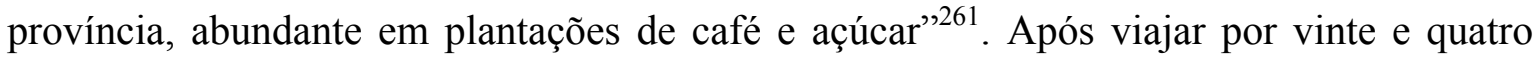

${ }^{261}$ D. P. Kidder e J. C. Fletcher. O Brasil e os brasileiros..., op. cit., vol. 2, p. 104. 
milhas, pernoitou em uma casa onde encontrou comida ruim e um quarto que, segundo o viajante, não caberia tal denominação.

Seguindo viagem, no dia 28 de junho chegou aos arredores de Campinas. E a sua descrição é sintomática da ótica que apresenta uma região, principalmente, através de informações sobre sua fertilidade e os efeitos das ações humanas:

\begin{abstract}
"Nosso local de descanso seria a importante cidade de Campinas (ou São Carlos), a mais de cem milhas do interior. Quando nos aproximamos dessa cidade, fui surpreendido pela beleza e fertilidade da região circundante. As grandes e antigas montanhas haviam sido deixadas muito para trás de nós, e em redor, até onde pude ver, estendiam-se extensas planícies, ou antes, prados ondulosos, com quase todos os acres ocupados. Havia muitas plantações de café superiormente cultivadas, entre cujo verde escuro podia-se avistar, aqui e ali, as grandes residências caiadas de branco dos proprietários das terras" ${ }^{\text {"262 }}$.
\end{abstract}

A mesma concepção é apresentada no caminho de Campinas para Ibicaba, fazendo Fletcher associar a região percorrida com os Estados Unidos: "O caráter recente das construções e plantações, me faria acreditar facilmente que estava na parte norte do Ohio" ${ }^{263}$. Os fatores que fizeram o viajante lembrar de sua terra natal como as construções e as terras cultivadas são interessantes, porque no início do relato diz serem os países sulamericanos seus parâmetros comparativos do progresso brasileiro, e não as nações com maior grau de desenvolvimento cultural, político e econômico, como os Estados Unidos, o que deixa claro sua ótica e seus modelos para a captação das particularidades paulistas, sua dinâmica e organização social e econômica.

Em Limeira encontrou um médico norte-americano, da Pensilvânia, que o acompanhou até a fazenda do Senador Vergueiro. Ao chegar à propriedade suas expectativas, criadas com base nas informações ouvidas, foram confirmadas e registra no seu relato: "Ao aproximarmo-nos do seu solar, vimos por todos os lados, provas de progresso" ${ }^{264}$. A boa impressão causada à primeira vista foi reiterada durante sua visita $\mathrm{e}$ nos seus apontamentos finais sobre a fazenda, pouco antes de deixá-la, diz:

"O Sr. Vergueiro e seus filhos estão realizando constantes melhoramentos no sentido da agricultura e estão estudando a melhor maneira de aplicar o trabalho e a capacidade do homem do norte à agricultura tropical. Mencionei em páginas anteriores as oficinas de mecânicos, onde os utensílios agrícolas em madeira e ferro são fabricados iguais em qualidade a quaisquer outros feitos na Europa ou na América do Norte. Entre as várias máquinas para facilitar a preparação

\footnotetext{
${ }^{262}$ D. P. Kidder e J. C. Fletcher. O Brasil e os brasileiros..., op. cit., vol. 2, p. 106-107.

${ }^{263}$ Ibidem, p. 109.

${ }^{264}$ Ibidem, p. 115.
} 
do café para o mercado, estava uma invenção do Senador Vergueiro que limpa nada menos de trinta e duas mil libras de café por dia"265.

Juntamente às observações escritas 0 viajante apresenta imagens do estabelecimento, como a que reproduzimos abaixo, proporcionando assim o duplo contato com a realidade da fazenda (textual e visualmente) e o melhor entendimento pelos leitores dos temas abordados.

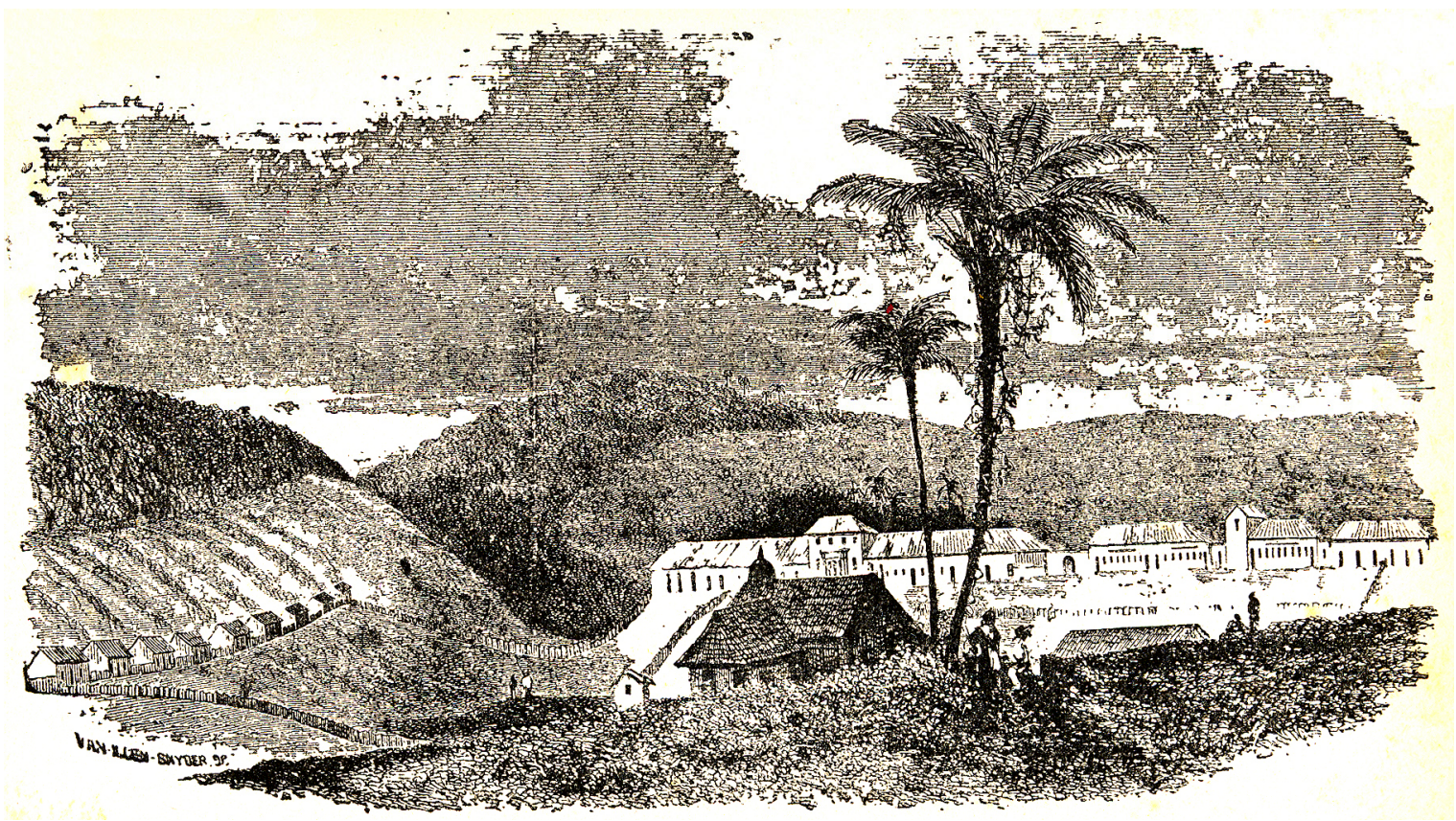

Figura 17. D. P. Kidder e J. C. Fletcher. "Fazenda do Senador Vergueiro, em Ibicaba", 1857. 15,2 x 8,5 cm. Ilustração da obra $O$ Brasil e os brasileiros (Esboço histórico e descritivo). São Paulo: Editora Nacional, 1941, p. 119.

A questão do progresso e da civilidade é fluída e permeia as informações sobre a propriedade. Quando trata dos meios de transporte utilizados diz: "Pela primeira vez fora do Rio de Janeiro, vi carros cujas rodas não eram da antiga e primitiva espécie romana, porém movendo-se sobre eixos como um carro de rodas civilizados. Note-se também que estes carros, todos os utensílios agrícolas e maquinismos, são fabricados na fazenda,"266. Ao percorrê-la destaca os melhoramentos realizados:

"Antes de alcançar o lugarejo atravessei um pequeno curso d'água sobre uma ponte de construção recente e barata, que por sua simplicidade recomendo a todo colono na Austrália ou na América Ocidental, onde os

\footnotetext{
${ }^{265}$ D. P. Kidder e J. C. Fletcher. O Brasil e os brasileiros..., op. cit., vol. 2, p. 126.

${ }^{266}$ Ibidem, p. 115-116.
} 
proprietários são muitos e os trabalhadores poucos. Pode ser qualificada como uma ponte feita por si própria. Certas qualidades de toros de madeira são unidos longitudinalmente dentro d'água, deixando-se, certamente, espaços entre os mesmos. Sobre eles, colocam-se grandes ramos, e depois galhos mais delgados; e na superfície é colocado certa quantidade de argila e terra solta",267.

O homem que projeta pontes e as realizadas através de seu esforço e dos recursos naturais disponíveis, como toras, galhos, ramos, argila e terra, é capaz de direcionar e se utilizar das capacidades naturais encontradas de acordo com seus imperativos. Tal como ocorreu na fazenda:

"Uma parte do curso d'água, acima da ponte, é desviada por uma vala que passa pelas terras ribeirinhas e leva as águas sobre os cepos e o montão de gravetos. Em poucos dias este pequeno desvio lateral tem aterrado uma imensa quantidade de solo vermelho por cima da ponte, tornando a superestrutura tão firme como a da estrada, enquanto em baixo, através dos ramos e cepos, o 'rio corre alegremente'. Tendo a água terminado seu trabalho, a vala é fechada, obtendo-se assim uma sólida passagem,268.

Suas atividades também estiveram voltadas para a análise da situação dos colonos alemães e suíços empregados na fazenda de Ibicaba, em Limeira. Segundo Fletcher:

"Foram-me permitidas todas as facilidades para um completo exame dos livros das plantações e condição da colônia, o que habilitou-me (sic) a fazer uma justa e clara comparação entre esse sistema de colonização e as de Petrópolis e Dona Francisca, e também para ver mais claramente os resultados dos trabalhos livre e escravos. O dia inteiro foi assim ocupado $[\ldots]^{\prime 269}$.

Os europeus que deixaram o Velho Continente e desembarcaram em São Paulo para trabalhar na propriedade do Senador Vergueiro ${ }^{270}$ eram contratados pelo sistema de parceria. De acordo com Sérgio Buarque de Holanda tal sistema foi "inaugurado no ano de 1847 [e] depois de empregar alguns milhares de colonos em diversas propriedades agrícolas, será de todo abandonado em $1860^{\text {„271 }}$. O viajante apresenta-o nos seguintes termos:

"O Sr. Vergueiro tem na Europa um agente, que se comunica com autoridades comunais e cantonais, ou diretamente com os interessados, oferecendo vantagens aos homens pobres e capazes que desejem emigrar

\footnotetext{
${ }^{267}$ D. P. Kidder e J. C. Fletcher. O Brasil e os brasileiros..., op. cit., vol. 2, p. 122.

${ }^{268}$ Ibidem.

${ }^{269}$ Ibidem, p. 116.

${ }^{270}$ Nicolau de Campos Vergueiro (1778-1859).

271 Sérgio Buarque de Holanda. São Paulo. In.: Sérgio Buarque de Holanda (org.). História Geral da Civilização Brasileira. O Brasil monárquico: dispersão e unidade..., op. cit.., vol. 2, p. 461.
} 
com as famílias para o Novo Mundo. O emigrante, por sua opção, pode pagar suas próprias despesas para chegar ao Brasil, ou, aceitar que o $\mathrm{Sr}$. Vergueiro o transporte, concordando, nesse caso, em reembolsar em tempo oportuno o preço de sua passagem, mais um pequeno juro. $\mathrm{O}$ agente em Hamburgo freta um navio, e assim um grande número de colonos estão habilitados a procurar um novo lar com uma despesa verdadeiramente módica.

O Sr. Vergueiro garante, por sua parte, pagar todas as despesas dos colonos, desde o litoral até às suas plantações, e, na chegada ao destino final, fornecer a cada chefe de família uma casa, tantos mil pés de café, proporcionalmente ao número de membros de cada família, e suprir com todas as provisões, roupas, etc., a preços por atacado. O colono, por sua vez, concorda em cuidar fielmente da porção de pés de café que lhe foi concedida, partilhar os proveitos e gastos da colheita, não deixar de prestar contas anualmente e pagar seus débitos (se existir) pela passagem adiantada" ${ }^{, 72}$.

Quando estabelecidos na fazenda, os gastos dos colonos eram registrados por um administrador que intermediava os pedidos e a compra destes artigos nos armazéns do Senador, isto é, o imigrante encomendava determinado produto, o administrador assinava a liberação da compra e só assim o colono podia efetuá-la.

A imigração dos suíços e alemães para trabalhar nas lavouras paulistas foi vista por Fletcher como benéfica tanto para os proprietários das fazendas e o governo brasileiro como para os colonos, e o sistema de parceria constituía "uma segura garantia para as partes contratantes" ${ }^{\text {273 }}$. Os últimos podiam livrar-se da condição de opressão e servidão na Europa, e no Brasil havia a possibilidade de prosperarem como agricultores e constituir famílias. Sob tal sistema seus interesses lhes evitariam a indolência, e "no prazo de um ano, depois de aprenderem, sob a tutela e a proteção de um enérgico brasileiro, a cultura de produtos tropicais, podem deixar a colônia e 'estabelecerem-se' por si próprio, se o preferem. Podem naturalizar-se facilmente; [e] seus filhos crescem como cidadãos ligados ao solo ${ }^{, 274}$.

A imagem de colonos felizes e prósperos ${ }^{275}$ é apresentada pelo viajante na ilustração reproduzida a seguir e quando visitou as casas dos imigrantes a uma milha de distância da sede da fazenda:

\footnotetext{
${ }^{272}$ D. P. Kidder e J. C. Fletcher. O Brasil e os brasileiros..., op. cit., vol. 2, p. 120.

${ }^{273}$ Ibidem.

${ }^{274}$ Ibidem, p. 125.

${ }^{275}$ Na primavera de 1855, no mesmo ano da visita de Fletcher, a fazenda Ibicaba do Senador Vergueiro, em Limeira, recebeu um grupo de imigrantes europeus. Dentre estes, desembarcou em São Paulo, juntamente com sua família, o suíço Thomas Davatz, que trabalhava como mestre escola em sua cidade natal. Suas esperanças e expectativas de melhores condições para ele, sua esposa e filhos foram ceifadas quando passou a trabalhar na propriedade do Senador. Segundo ele, os termos do contrato do sistema de parceria não foram
} 
"Ao passar pelas mesmas, era constantemente saudado por alegres trabalhadores suíços e alemães, alguns dos quais rodeados de crianças, turbulentas, alegres e bonitas que brincavam em volta com tanta vida e alegria como se estivessem ao sopé do Hartz ou nos vales de Oberland"276.

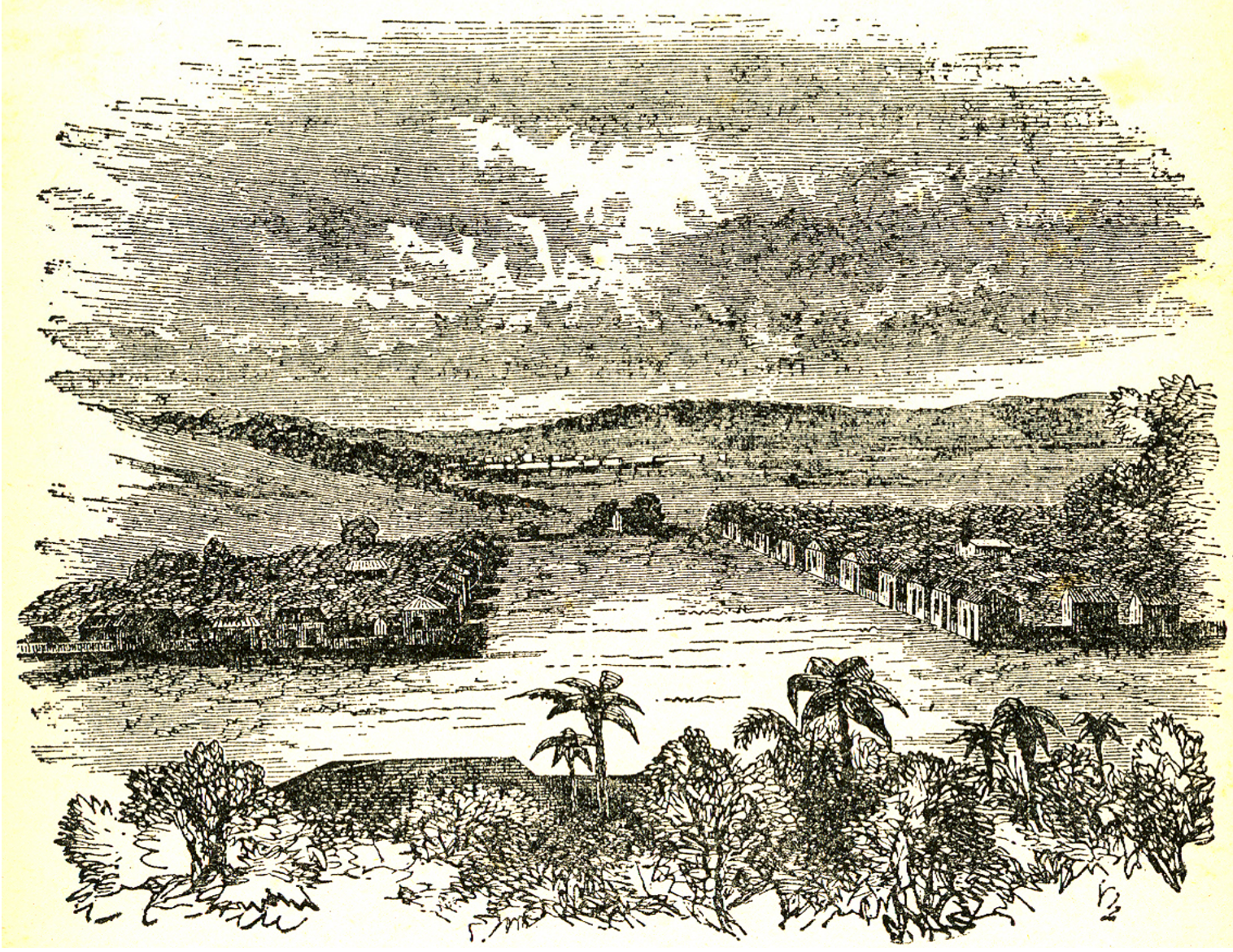

Figura 18. D. P. Kidder e J. C. Fletcher. "Colônia Vergueiro", 1857. 9 x 8,7 cm. Ilustração da obra $O$ Brasil e os brasileiros (Esboço histórico e descritivo). São Paulo: Editora Nacional, p. 121.

cumpridos, os colonos eram alvo de altos juros e outras arbitrariedades, foram ameaçados e seus pagamentos não eram efetuados corretamente. Considerando-se enganado procurou ajuda de oficiais brasileiros e envolvidos na imigração, e também daqueles que pudessem lhes ajudar sem estarem a serviço do governo do Brasil e da Suíça. Mas diante dos resultados quase nulos, decidiu se unir a outros colonos contra as opressões sofridas. Seu objetivo, segundo aponta, não era incitar uma revolução no Brasil, mas sim propor o "esclarecimento amplo de nossas condições e um apelo vigoroso e oportuno, para que obtivéssemos aquilo que desejávamos: vermo-nos livres dos opressores, que em nossa opinião tinham violado os contratos de muitos modos, tornando-os nulos, e conquistar o direito de viver como cidadãos felizes e súditos do governo do país". Foi aberta uma sindicância e as conclusões apresentadas no dia 9 de março de 1857. Na noite seguinte Thomas Davatz foi embora da fazenda com destino a Santos, onde esperou até o dia 19 para embarcar para o Rio de Janeiro. Sua família deixou Ibicaba em 15 de março e demorou 16 dias para chegar a Santos. No dia 2 de abril o suíço e sua família se encontraram no Rio de Janeiro. Em 21 de julho de 1857 chegou a sua terra natal, onde passou a escrever um relato sobre suas experiências em São Paulo com o principal objetivo de "advertir tanto quanto possível contra a leviandade das emigrações e trabalhar um pouco para que se acalme a febre de emigrar, mesmo quando ela dirige a outros centros (América do Norte, Austrália, etc.), poupando a muita gente amargas desilusões". Thomas Davatz. Memórias de um colono no Brasil (1850). Trad. Sérgio Buarque de Holanda. São Paulo: Livraria Martins, 1941, p. 140 e 38.

${ }^{276}$ D. P. Kidder e J. C. Fletcher. O Brasil e os brasileiros..., op. cit., vol. 2, p. 121. 
O "plano Vergueiro", como o chama Fletcher, era excelente por "sua aplicabilidade em todo o Império, em grande ou pequena escala"277, e, em âmbito nacional, tal plano resolveria uma importante questão: "Qual o verdadeiro modo de realizar a colonização no Brasil?"278. A extinção do trabalho escravo acarretaria uma falta de trabalhadores nas lavouras, e a vinda de portugueses, alemães e suíços é vista como uma solução. Em conversa com o Senador Vergueiro perguntou-lhe "se era mera filantropia que inspirava seus esforços para introduzir o trabalho livre, [ele] respondeu, muito prontamente e decididamente: 'Achamos o trabalho do homem que tem sua própria vontade e interesses na empresa, muitíssimo mais aproveitável do que o trabalho do escravo"279.

Devido à forma como o contrato era elaborado, tal sistema é visto por ele como mais próspero para os imigrantes e seus empregadores quando comparado às colônias fundadas pelo governo imperial e autoridades provinciais, e tal como Kidder - quando trata da Fábrica de Ipanema - critica o mau desempenho dos estabelecimentos sob o controle estatal. Para tal afirmação o viajante se baseia nos seguintes dados:

"Pelo relatório do Ministro do Império de 1854-55, verifico que, além das dezessete colônias fundadas pelo governo Imperial ou pelas autoridades provinciais, apenas quatro podem ser consideradas prósperas; e apenas duas 'muito prósperas'. As restantes são classificadas como 'não prósperas', 'confundidas com a população', 'em decadência', ou 'falta de informação sobre o seu estado'. De vinte e quatro tentativas privadas de colonização, vinte e uma são consideradas prósperas, quase todas tendo sido fundados depois de 1852, e mais ou menos pelo sistema Vergueiro. Estas colônias estão situadas em cinco províncias, e a excelência do 'plano Vergueiro' consiste no seguinte: sua aplicabilidade em todo o Império, em grande ou pequena escala. Nove dos vinte e um senhores, têm menos de cento e vinte colonos, habilitando assim os pequenos proprietários a ter, até certo ponto, as vantagens dos proprietários de fazendas maiores" ${ }^{280}$.

Segundo Fletcher, as vantagens e os bons resultados deveriam ser maximizados com a modificação das leis pelo Governo Imperial para facilitar a introdução dos colonos. Assim, o empenho e a vontade de todos os envolvidos, associado ao alargamento do trabalho livre no Brasil para ele "promoveriam a imigração, e, com o tempo, uma nova população cresceria neste belo país, digno de seus vastos recursos. Que um puro

\footnotetext{
${ }^{277}$ D. P. Kidder e J. C. Fletcher. O Brasil e os brasileiros..., op. cit., vol. 2, p. 124.

${ }^{278}$ Ibidem, p. 115.

${ }^{279}$ Ibidem, p. 123.

${ }^{280}$ Ibidem, p. 123-124. [Itálicos do autor].
} 
evangelho possa estar nos corações de um tal povo [sic], e o Brasil, no futuro, será uma terra a todos os respeitos não sobrepujada em toda a face da terra, ${ }^{\text {,281. }}$.

O relato de Kidder e Fletcher foi sendo constantemente atualizado, e a cada nova edição apresentava as modificações e transformações tanto brasileiras como internacionais. No ano de 1866 foi lançada a $6^{\mathrm{a}}$ edição da obra, que contou com dados sobre as conseqüências projetadas no Brasil da Guerra Civil nos Estados Unidos. A imigração de norte-americanos, em especial dos agricultores do sul, também foi aventada. Na nota 51 escreve:

\begin{abstract}
"Nota de 1866 - [...] A conclusão de uma longa luta interna nos Estados Unidos obrigou a muitos plantadores do sul a procurar o Brasil. $\mathrm{O}$ Governo Imperial, como se tem dito, está determinado a recebê-los da forma a mais liberal; e a colonização que, deve ser confessado, não tem cumprido a expectativa de seus amigos, dará lugar a (sic) imigração, que tem feito tanto pelos Estados Unidos; se o Governo do Brasil fosse decididamente liberal e cumprisse suas promessas, a saber, vender a terra barata e cortar o burocratismo dos funcionários públicos e inferiores fiscais e sub-delegados, nova gente será introduzida a qual multiplicará o bem estar e a honra do Império" ${ }^{282}$.
\end{abstract}

A Província de São Paulo, assim como todas no sul do Brasil, é considerada pelo pastor metodista como próspera e melhor capacitada para a instalação dos imigrantes norte-americanos, com inúmeros atrativos naturais possíveis de serem explorados e locais apropriados para a criação de carneiros, tema já abordado entre ministros brasileiros e alguns dos seus conterrâneos. As terras paulistas são vistas através de uma lente que enfoca suas potencialidades visando à possível instalação de colonos. Fletcher afirma:

"Nota de 1866 - A província de São Paulo, com outras províncias do Sul, por seu clima, solo, etc., oferece muitos atrativos para os emigrantes dos Estados Unidos. As porções montanhosas de São Paulo, Paraná, Sta. Catarina e Rio Grande do Sul são as mais bem adaptadas à criação de carneiros. Uma oferta muito agradável de quatro belos merinos, foi feita pelo Dr. George B. Loring, de Salem, Massachusetts, ao Imperados do Brasil, em 1865. As ovelhas foram recebidas no Rio, com agradecimentos pelo Imperador, e foram colocadas em mãos de $\mathrm{Mr}$. John Hayes, o enérgico e inteligente diretor americano das plantações do Barão de Mauá. Estas ovelhas seriam o começo de melhorias introduzidas na raça bovina das províncias do Sul. O Sr. Marcondes [Jesuino Marcondes de Oliveira e Sá], Ministro da Agricultura no Gabinete de Agosto de 1864, e o Sr. Paulo Souza [Antônio Francisco de Paula Souza], ocupando o mesmo posto no Gabinete de Maio de 1865, louvaram altamente a dádiva do Dr. Loring" ${ }^{283}$.

\footnotetext{
${ }^{281}$ D. P. Kidder e J. C. Fletcher. O Brasil e os brasileiros..., op. cit., vol. 2, 125-126.

${ }^{282}$ Ibidem, p. 126.

${ }^{283}$ Ibidem, p. 145.
} 
Após visitar a Fazenda de Ibicaba e depois de observar os resultados do sistema de parceria e como viviam os colonos, deixou a propriedade do Senador seguindo para Limeira, de onde partiu no dia 2 de julho em direção à Campinas, e pernoitou nesta localidade. No dia seguinte viajou para a cidade de São Paulo com destino a Santos. A região percorrida é apresentada como "muito bem cultivada, de grandes plantações de café estendendo-se de um e outro lado, até onde a vista podia alcançar, entremeadas com campos de cana de açúcar ou tufos de matas umbrosas"284.

A 6 de julho de 1855 deixou as terras paulistas com destino à capital carioca, e registra que as experiências vividas não foram sobrepujadas por nenhuma outra localidade brasileira. Durante a viagem para o Rio de Janeiro diz: "De São Sebastião até Pão de Açúcar, fomos levado em belo estilo através de um mar furioso, mas o sol brilhou muito mais quando no dia seguinte nos encontramos debaixo dos canhões de Villegagnon, e o glorioso panorama da magnifica baía, cintilante na frescura da manhã, nada perdeu de seu esplendor em comparação com as lindas cenas que testemunhara no Sul do Brasil, e que depois verifiquei não ter rival nas províncias do Norte ${ }^{, 285}$.

\footnotetext{
${ }^{284}$ D. P. Kidder e J. C. Fletcher. O Brasil e os brasileiros..., op. cit., vol. 2, p. 137.

${ }^{285}$ Ibidem, p. 144-145.
} 


\subsection{Aubertin visita o interior da Província de São Paulo}

Ao longo do século XIX os fazendeiros norte-americanos produtores de algodão colocaram seu país no patamar de maior exportador do gênero para os países europeus, sendo quase toda matéria-prima importada pela Inglaterra fornecida por eles. Durante a Guerra Civil nos Estados Unidos (1861-1865) este quadro foi alterado, com a destruição de inúmeras propriedades agrícolas, especialmente nos Estados do Sul, onde a lavoura algodoeira era predominante.

Com o arrasamento das plantações e propriedades houve uma diminuição drástica da produção e a busca de muitos proprietários por outras terras onde pudessem se estabelecer e cultivar. A procura de outras áreas para colonizar os Drs. Gaston e Shaw e o Major Mereweather desembarcaram em São Paulo. Aubertin os apresenta nos seguintes termos:

"Era bom, talvez, agora explicar que os srs. dr. Shaw e major Mereweather tem (sic) sido cultivadores do algodão por toda a sua vida nos Estados Sulistas; (sendo o major Mereweather filho também de um bem conhecido lavrador), e, nessa ocupação, na qual estão ambos perfeitamente inteirados, passaram a sua vida agrícola até que abandonaram o arado para tomar a espada. Nem brandiam uma espada virgem! O ilustre sr. dr. Gaston sem se ter ocupado em semelhante cultura, também se tem devotado ultimamente com afinco ao assunto como também a todos os demais que interessam (sic) a esperada imigração.

Assim, com a sua assiduidade perpétua, e capacidades literárias, é ele um campeão inestimável do movimento" ${ }^{286}$.

A presença do britânico superintendente da Estrada de ferro de São Paulo em terras paulistas também foi moldada pelas conseqüências da Guerra de Secessão norteamericana. Com a interrupção do fluxo de matéria-prima exportada para a Inglaterra, esta fez uma campanha mundial para implantar e expandir a cultura algodoeira no Brasil, no Egito, na Índia e em outros países capazes de lhe fornecer material para sua indústria têxtil em franco desenvolvimento.

$\mathrm{Na}$ província paulista Aubertin lançou-se no esforço de incentivar a produção algodoeira. Suas ações abarcavam uma vasta gama de atividades: escrevia para diversos jornais, trocava correspondência com os membros da Associação para o Suprimento do Algodão de Manchester, enviava algodão de diferentes regiões para serem examinados na

${ }^{286}$ J. J. Aubertin. Onze dias de viagem na Província de São Paulo..., op. cit., p. 7-8. 
Inglaterra, atuou na afirmação de uma corrente de agricultores empenhados no cultivo do algodão, expôs amostras da produção paulista na Exposição Universal de Londres, se comunicava com a Sociedade Auxiliadora da Indústria Nacional, aconselhava sobre temas relacionados à lavoura algodoeira, foi incentivador da imigração norte-americana e incursionava por terras paulistas em busca de regiões nas quais o algodão encontrasse condições favoráveis para ser cultivado.

A viagem realizada em companhia dos norte-americanos sulistas, feita no final do ano de 1865, foi registrada na obra Onze dias de viagem na Província de São Paulo com os Srs. Americanos Drs. Gastón e Shaw, e o Major Mereweather. 1865. Carta dirigida ao Illm. e Exm. Sr. Barão de Piracicaba.

Ao saber da viagem dos três norte-americanos pelos distritos paulistas, sob a direção do engenheiro Benatton, se juntou ao grupo. Na tarde de 18 de dezembro de 1865 deixou a cidade de São Paulo, e pernoitou na fazenda do Tenente Joaquim José da Silva, onde visitou a primeira plantação de algodão.

No dia 20 do mesmo mês se encontraram na fazenda do Barão de Piracicaba, em Itu. A propriedade foi visitada pelo grupo na companhia do próprio Barão. Ao relatar a visita destaca a impressão favorável tanto dele como dos outros integrantes, não só devido às belezas naturais, mas também às capacidades naturais da região:

"O rio por cujas margens pacíficas no dia anterior [quando iam para a
fazenda] tínhamos por algumas léguas seguido pensando na navegação
que talvez pudesse oferecer aos distritos próximos, tinha de repente
mudado os sussurros das suas correntes pelo estrépito de seus saltos, e
ali contemplando o Schaffhausen no Rheno em miniatura, vimos águas
turbulentas e desabridas, ameaçando só a morte violenta, as quais sendo
por arte subjugadas e dirigidas, serviriam para a riqueza e o
contentamento de milhares! Que vantagens ainda mortas e perdidas"287.

Deixando a fazenda, seguiram viagem passando por Salto e Porto Feliz, onde cruzaram o Rio Tietê e conheceram a Fábrica de Ipanema. Em Sorocaba ficaram hospedados na casa do Coronel Manoel Lopes de Oliveira, percorreram suas plantações e viram o processamento do algodão na fazenda, assim como o seu maquinário e o de Carlos Tolomei. Sobre o local, o destaque é para a alta qualidade e a grande quantidade de algodão produzido:

"Tanto pela sua qualidade geral - enquanto à quantidade, (embora garantida por muitas pessoas fidedignas e até pelo snr. Coronel Lopes mesmo) quando me deixaram, seguindo para Itapetininga, estavam [os

${ }^{287}$ J. J. Aubertin. Onze dias de viagem na Província de São Paulo..., op. cit., p. 8. 
norte-americanos] ainda quase descrentes, embora quase persuadidos do fato atual. Em poucas palavras, enquanto o alqueire norte-americano, dando bem, produz de cem até cento e dez ou talvez vinte arrobas em caroço, todos os plantadores aqui concordam no fato do alqueire paulistano dar quase sempre muito além de duzentas e em muitos exemplos além de trezentas, e até em algumas boas cultivações quatrocentas!"288.

A cultura algodoeira em Sorocaba se desenvolveu principalmente após 1862, quando a feira de animais na região começava a apresentar sinais de decadência. A intensidade e extensão da lavoura algodoeira nas terras sorocabanas se devem a um quadro diferenciado daquele encontrado na maior parte da Província de São Paulo ${ }^{289}$. Conforme destaca Alice Canabrava: “A cultura do algodão surgia, portanto, em Sorocaba, como um ramo de exploração que vinha providencialmente substituir o comércio de animais que a estrada de ferro parecia destinar irremediavelmente ao desaparecimento total. Dessa maneira, ela encontrava, juntamente com a ausência de resistência social representada por interesses de outra cultura sólida e próspera, os capitais e a mão-de-obra em disponibilidade os quais podiam ser colocados a seu serviço" ${ }^{290}$.

A mudança do foco das atividades relacionadas à feira de animais para a lavoura algodoeira foi vista por Aubertin como um sinal do futuro promissor sorocabano e paulista, e afirma:

"Tanto mais apreciei eu tudo por saber que os meus companheiros o apreciavam, dizendo-me, repetidas vezes, que melhor algodão nem quereriam nem podiam cultivar no seu país. E enquanto estávamos examinando e tomando conta de tudo, refletindo sobre a imensa importância do produto, a grande falta no seu suprimento que está sofrendo o mundo inteiro, e os grande resultados felizes, diretos e indiretos, da sua cultivação extensa não se pode deixar de perguntar: 'Não vale tudo isso mais, não pertence muito mais aos dias futuros e ilustrados do país, de que a feira mais bonita de animais!" ${ }^{291}$.

\footnotetext{
${ }^{288}$ J. J. Aubertin. Onze dias de viagem na Província de São Paulo..., op. cit., p. 16-17.

289 “A quarta empresa constituída à época - a Sorocabana - apresenta-se com uma característica distinta. A elevação dos preços do algodão no mercado internacional durante a Guerra de Secessão norte-americana estimulara a plantação do algodão na região de Sorocaba (em São Paulo). Um grande comerciante do produto - Luiz Matheus Mailasky - procurando reduzir os custos de transporte do algodão, organizou a empresa ferroviária, junto com alguns proprietários de terra, financiando sua instalação. Mais tarde, com o declínio da produção algodoeira, a Sorocabana também se transformaria numa estrada de ferro do café". Flávio de Saes. A Grande Empresa de Serviços Públicos na Economia Cafeeira. São Paulo: Hucitec, 1986, p. 44-46. apud. Flávio de Saes. Estradas de ferro e diversificação da atividade econômica na expansão cafeeira em São Paulo, 1870-1900. In.: História econômica da Independência e do Império. Tamás Szmrecsányi e José do Amaral Lapa (org.). 2. ed. rev. São Paulo: Hucitec, ABPHE, Edusp, Imprensa Oficial, 2002, p. 182.

${ }^{290}$ Alice P. Canabrava. O algodão em São Paulo..., op. cit., p. 66.

${ }^{291}$ J. J. Aubertin. Onze dias de viagem na Província de São Paulo..., op. cit., p. 15-16.
} 
Apesar do empenho do britânico, um dos limites da lavoura algodoeira foi que grande parte dos agricultores entendeu que o interesse por este gênero era provisório e sua expansão seria sempre limitada pelos acontecimentos internacionais, e com isso preferiram direcionar seus esforços e capital para cultura não instituída em alicerces tão frágeis. Aubertin, com base nas potencialidades e capacidade vistas, escreve e apela aos descrentes sobre a qualidade, alta produtividade e a existência dos recursos naturais perfeitos para o cultivo do algodão, mais apropriados, inclusive, do que os norte-americanos, porque em São Paulo não havia geada, que ocorria nos Estados Unidos, e o clima paulista era considerado mais adequado, com melhor possibilidade de conservar o algodoeiro por dois ou três anos apenas com poda. Para os relutantes diz:

"Deveras já é tarde demais para duvidar do algodão de São Paulo; mas se ainda há descrentes, apenas apelo para os dois srs. Cultivadores que acompanhei, major Mereweather e dr. Shaw. Ambos eles me repetiram muitas vezes, que melhor algodão que aquele que nos vimos não desejavam ver; que nas suas próprias plantações e com todos os seus meios perfeitos não costumavam produzir melhor" ${ }^{292}$.

Após visitar as fazendas, ver as plantações e discutir longamente com o grupo sobre a viagem, a região e o algodão, deixa-os em Sorocaba na companhia de Bennanton. Os norte-americanos seguiram para Itapetininga ${ }^{293}$ e o viajante voltou para a capital. Seus últimos registros da viagem sobre a visita dos drs. Shaw e Gaston e do major Mereweather são:

"Enfim, meu distinto amigo sr. Barão, os três senhores Americanos, que tiveram a bonita ocasião de gozar das benevolências de v. exc. Completaram sua visita a Sorocaba e saíram com o sr. Bennanton, contentíssimos, seguindo para Itapetininga, procurando ainda novas informações. Não pude - infelizmente - continuar a minha viagem, tendo deveres que chamavam para a Capital. Mas as palavras, que na despedida me dirigia o sr. Major Mereweather, não esqueço, nem acho que devem ser esquecidas, porque mostram, que o curto tempo que

\footnotetext{
292 J. J. Aubertin. Onze dias de viagem na Província de São Paulo..., op. cit., p. 16.

293 "Na direção sul, nos campos além de Sorocaba, até os limites da província do Paraná, o algodoeiro herbáceo estava conquistando rapidamente o terreno. Nessa área, contudo, Itapetininga se distinguiu desde cedo como um dos mais ativos centros produtores de algodão da Província. [...] Em 1864 a cultura do algodoeiro herbáceo adquiriu aí grande impulso; nesse ano, o município de Itapetininga juntamente com o de Sorocaba se destacavam na Província pelo desenvolvimento que haviam dado à cultura do algodoeiro. Em Dezembro de 1865 contavam-se, nos arredores da povoação, quatro máquinas de descaroçar, enquanto outras estavam sendo assentadas dentro da cidade, completando um total de oito. A produção local de 1866 se avaliava em 30 a 40 mil arrobas de algodão descaroçado e, nesse ano, chegavam à cidade os primeiros descaroçadores tocados a vapor. Apesar da ausência de comunicações com o litoral na parte meridional da Província, que dificultava a exportação do produto, sentia-se uma aura de progresso que imprimia ritmo novo a toda a vida da cidade. Como dizia o seu correspondente, "Aqui tudo vai em progressivo aumento. $\mathrm{O}$ algodão vai transformando tudo[...]”.Alice P. Canabrava. O algodão em São Paulo..., op. cit., p. 69-70.
} 
passei com eles não foi inutilmente empregado, nem baldo de impressões positivas.

'Sr. Aubertin', me disse ele, 'vamos muito mais longe para ver tudo; mas já vi bastante para me persuadir, que esta província, bem e sistematicamente cultivada contém uma capacidade extraordinária para a cultivação do algodão. Estabelecendo-nos aqui, conforme os nossos desejos, seríamos capazes de produzir o algodão e o milho, em escala gigantesca; e mais uma palavra; em face de tudo que nós vimos juntos, digo-lhe que embora $\mathrm{V}$. tanto contribuísse para o novo movimento, lhe desafio de fazê-lo, por qualquer modo, outra vez desaparecer'. E acredite-me, o sr. Barão, que a esse respeito seria o primeiro a proclamar a minha profunda incapacidade" 294 .

A seguir inserimos o mapa simplificado da Província de São Paulo para a localização das regiões visitadas por Aubertin e os norte-americanos descritas no relato. Este mapa tem como base o material cartográfico elaborado por Francisco Luna e Herbert Klein sobre as principais rotas comerciais de São Paulo no século XVIII. De acordo com nosso objetivo, foram feitas as alterações necessárias visando adequá-lo ao contexto do século XIX e ao roteiro da viagem ${ }^{295}$.

\footnotetext{
${ }^{294}$ J. J. Aubertin. Onze dias de viagem na Província de São Paulo..., op. cit., p. 19-20.

${ }^{295}$ Francisco Vidal Luna e Herbert S. Klein. Evolução da sociedade e economia escravista de São Paulo..., op. cit., p. 35.
} 


\section{MAPA 6 - Regiões paulistas percorridas por J. J. Aubertin, Drs. Gastón e Shaw e Major Mereweather em 1865}

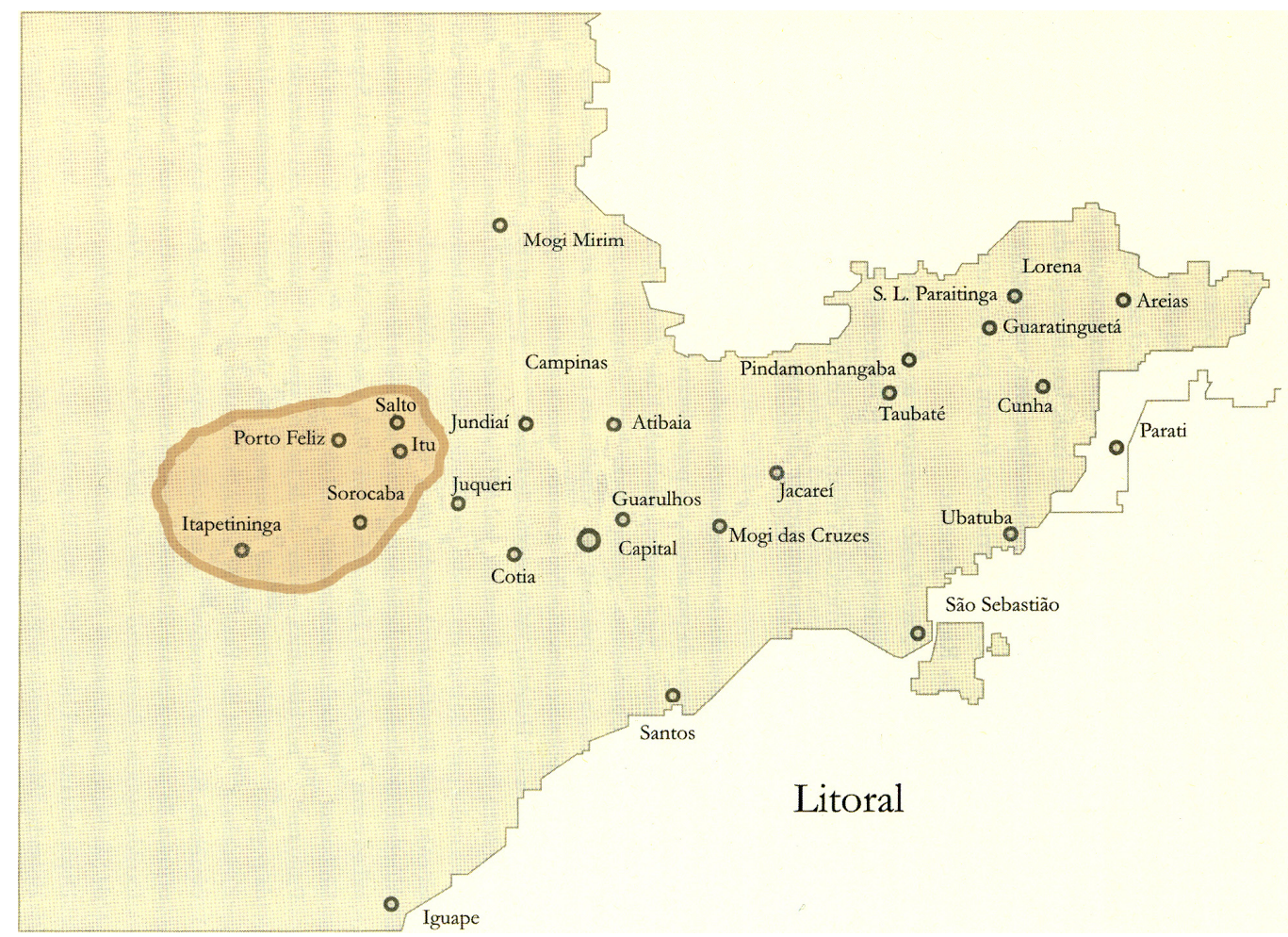

FONTE: Francisco Vidal Luna e Herbert S. Klein. Evolução da sociedade e economia escravista de São Paulo, de 1750 a 1850. São Paulo: Edusp, 2005, p. 35.

As considerações de Aubertin sobre a Província de São Paulo também abordam os entraves para o escoamento da produção e as limitações para o comércio direto entre Santos e os mercados internacionais. Sua primeira observação recai na falta de caminhos eficientes e planejados ${ }^{296}$, inclusive esta queixa foi feita pelos norte-americanos a ele. Segundo Alice Canabrava: "A freqüência das reclamações sobre o péssimo estado das vias freqüentemente interrompidas pelos lamaçais produzidos pelas chuvas, pela queda de pontes, e até pela invasão da vegetação, quando se negligenciavam por alguns anos os

\footnotetext{
${ }^{296}$ O problema dos precários caminhos também foi uma das barreiras para a expansão das culturas açucareira e cafeeira na Província de São Paulo. Como apontam Francisco Luna e Herbert Klein: "Nas décadas intermediárias do século XIX, o açúcar, conforme observamos, já não era tão importante na economia paulista nem o setor dinâmico que fora no início do século. O papel de impulsionar a importação de escravos, melhorar os transportes e reorganizar a economia passou aos produtores de café. Mas os cafeicultores deparariam com os mesmo problemas enfrentados anteriormente pelos senhores de engenho. A necessidade de números cada vez maiores de escravos e a de melhores caminhos e postos de parada a fim de proteger as mercadorias transportadas quando as mulas eram descarregadas foram os fatores limitadores da expansão do setor cafeeiro, como haviam sido da pioneira economia açucareira de grande lavoura". Francisco Vidal Luna e Herbert S. Klein. Evolução da sociedade e economia escravista de São Paulo..., op. cit., p. 76.
} 
trabalhos de descortinamento, nos leva a admitir que o mau estado das estradas de ferro era a situação normal. Essas condições, que caracterizavam os meios de comunicação da época, dificultavam o maior incremento da cultura do algodão, além da área central da Província, nas regiões pioneiras, onde a precariedade dos investimentos financeiros poderia ter propiciado seu maior desenvolvimento" 297.

Em 9 de dezembro de 1865, o Ministério dos Negócios da Agricultura havia nomeado o engenheiro civil Newton Bennaton para a construção de estradas de ferro que atendessem à demanda, segundo o viajante, dos distritos mais férteis da província. Para o autor inglês esta questão era urgente e "é uma obra que precisa muitas mãos, muito dinheiro e muita pressa na sua realização, nem posso conceber qualquer outra questão publica da atualidade mais importante, se for deverás qualquer de importância igual” ${ }^{298}$.

Outro tema abordado por ele foi a necessidade da ligação direta entre Santos e o mercado consumidor internacional, pois naquele ano de 1865 desembarcou no porto de Santos o primeiro navio mercante inglês: o Saladin, de Liverpool, e outra embarcação, o Herschell, tentou atracar em São Paulo, mas naufragou antes de alcançar os portos paulistas, como escreve o viajante.

Para dotar esta questão de toda a importância e urgência que considerava pertinente cita um parágrafo do Times, de 5 de dezembro [1865], sobre as queixas dos negociantes cariocas diante do aumento do volume da produção algodoeira de São Paulo e da falta de comunicação direta com Santos. E destaca que a Inglaterra, enérgica quando trata de assuntos comerciais, em conseqüência deste parágrafo publicou no dia seguinte uma carta para chamar a atenção de todos sobre o tema:

"Liverpool, 6 de Dezembro

'Senhor. - Seu artigo comercial de ontem faz referência às representações dos negociantes no Rio a respeito do assunto de comunicações [sic] por vapor entre Santos e a Europa, e insiste que a linha de vapores entre Liverpool e Brasil devia visitar aquele porto. A's representações assim avançadas, os acionistas dos vapores mencionados não podem dar senão uma só resposta, e vem a ser, que hoje resolveram que o vapor NEWTON, deixando Liverpool para o Brasil no dia 9, deve proceder a Santos, e que uma comunicação semelhante continuará cada mês dali para diante, enquanto o comércio oferecer bastante atração" 299 .

No mesmo ano da visita de Aubertin o porto santista foi registrado na fotografia reproduzida abaixo, cuja autoria é atribuída a Militão Augusto de Azevedo.

\footnotetext{
297 Alice P. Canabrava. O algodão em São Paulo..., op. cit., p. 114.

${ }^{298}$ J. J. Aubertin. Onze dias de viagem na Província de São Paulo..., op. cit., p. 26-27.

${ }^{299}$ Ibidem, p. 33. [Itálico do autor].
} 


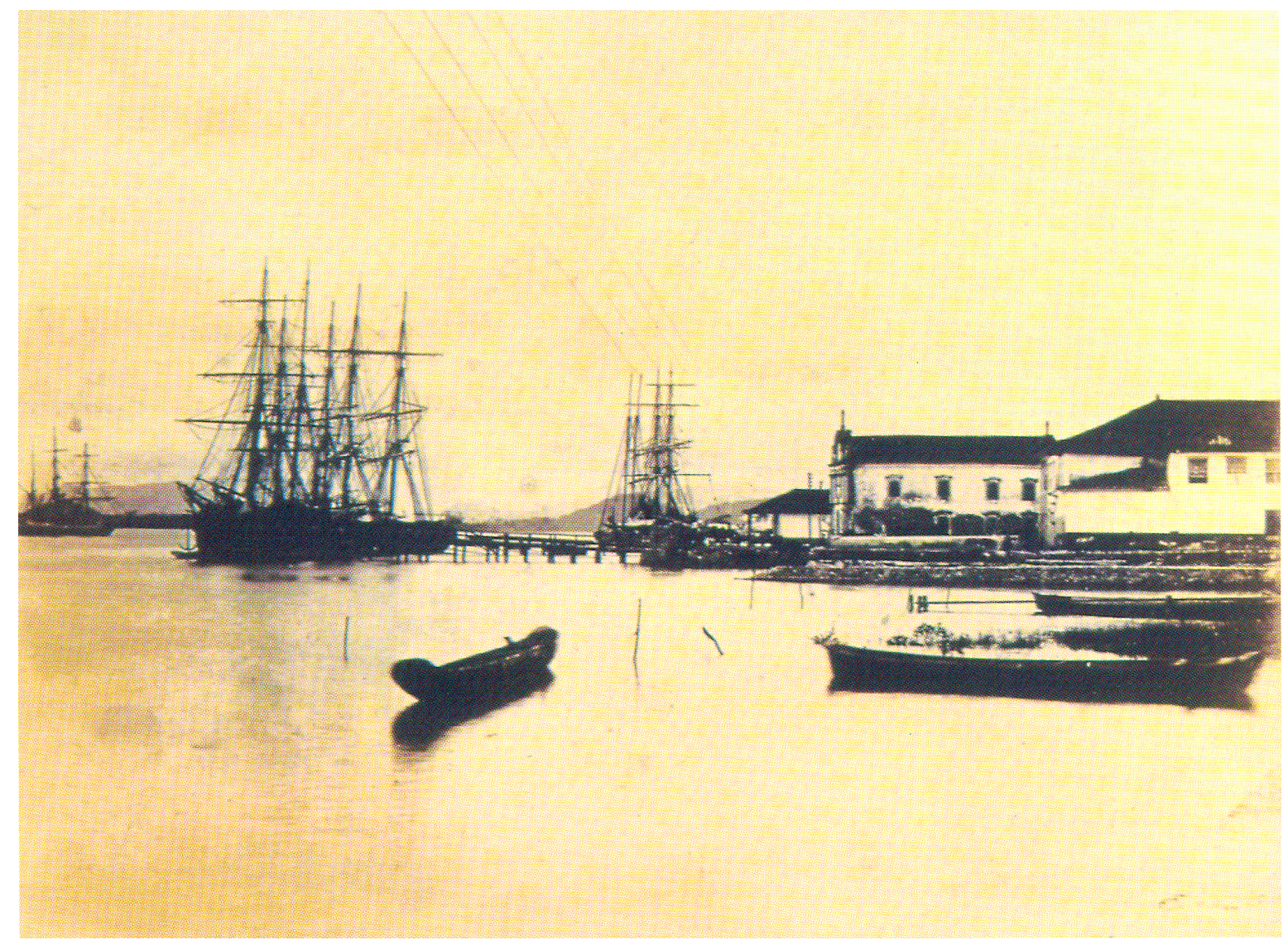

Figura 19. Militão Augusto de Azevedo (atribuição). "Porto de Santos, 1865". Fotografia sobre papel luminado. In.: Carlos Eugênio Marcondes de Moura. Até onde o olhar alcança. In.: Carlos Eugênio Marcondes de Moura (org.). Vida cotidiana em São Paulo no século XIX: memórias, depoimentos, evocações. São Paulo: Ateliê Editorial: Fundação Editora UNESP: Imprensa Oficial do Estado: Secretaria de Estado da Cultura, 1998, p. 398.

Com a comunicação direta entre Santos e a Europa aumentou o volume exportado e houve uma mudança na dinâmica dos caminhos para o escoamento da produção, pois "enquanto que, em 1865, a maior parte do algodão vendido e despachado no Rio de Janeiro, era de procedência paulista, cinco anos depois notava-se uma situação diferente, pois das vendas efetuadas no Rio de Janeiro a maior parte era de algodão paulista a ser embarcado diretamente de Santos"300.

TABELA 8 - Exportação do algodão da Província de S. Paulo (fardos)

\begin{tabular}{|c|c|c|c|c|}
\hline Destino & $\mathbf{1 8 6 5 - 6 6}$ & $\mathbf{1 8 6 7 - 6 8}$ & $\mathbf{1 8 6 8 - 6 9}$ & $\mathbf{1 8 6 9 - 7 0}$ \\
\hline & & & & \\
\hline Liverpool & 9.348 & 54.369 & 69.074 & 44.794 \\
\hline Havre & 2.452 & 3.277 & 26.011 & 50.730 \\
\hline
\end{tabular}

FONTE: A situação da cultura do algodão em nossa Província. Diário de S. Paulo. 4-1-1873, p. 2. apud. Alice P. Canabrava. O algodão em São Paulo: 1861-1875. 2. ed. São Paulo: Ed. T. A. Queiroz, 1984, p. 7.

${ }^{300}$ Alice P. Canabrava. O algodão em São Paulo..., op. cit., p. 268. 
Na tarde de 28 de dezembro de 1865 o autor retornou à cidade de São Paulo. Seu relato, publicado em 1866, nos apresenta um viajante britânico movido pela ânsia de implantar a lavoura algodoeira na Província paulista e de ligá-la ao mercado consumidor internacional. Munido de tais objetivos, percorreu um trecho de seu território visando mapear a capacidade para o cultivo deste gênero e o estabelecimento de imigrantes norteamericanos. Conforme a ótica utilitarista, o rio é apresentado pela sua potência motriz. A região visitada é descrita de acordo com as lavouras encontradas, sua fertilidade e produção. $\mathrm{O}$ que lhe encantou foram os maquinários desenvolvidos pelo homem para o processamento do algodão.

Suas sugestões são pragmáticas: as dificuldades deveriam ser solucionadas; os recursos naturais explorados em sua plenitude; os caminhos deveriam ser melhorados e as distâncias encurtadas, porque a Província tinha chamado o mundo para com ela comercializar. O que o superintendente ansiava era o progresso necessário para seu crescimento, enriquecimento e uma estrutura capaz de responder à demanda internacional.

Em maio de 1868 Aubertin deixou o Brasil, mas manteve seu interesse pela cultura algodoeira brasileira, sobretudo em São Paulo ${ }^{301}$.

${ }^{301}$ Alice P. Canabrava. O algodão em São Paulo..., op. cit., p. 13. 


\section{Aubertin visita a Fábrica de Ferro de Ipanema}

Aubertin esteve na Fábrica de Ipanema, em 1865, e apesar de Pink e de Kidder terem visitado o estabelecimento anos antes dele, em 1823 e 1839 respectivamente, o tom de reprovação pela situação decadente do estabelecimento encontrado é o mesmo nos relatos dos três viajantes.

No dia 23 de dezembro às 6 horas da manhã ele saiu em companhia do grupo de norte-americanos para visitar a fábrica e na época era diretor o Capitão Joaquim de Souza Mursa, que assumiu o estabelecimento em 6 de setembro de 1865. Segundo Salazar, "Mursa deve ter encontrado a fábrica num estado lastimável, e possivelmente, trabalhou arduamente no engajamento de bons técnicos e operários, assim como na preparação do estabelecimento e sua organização"302.

Se Pink e Kidder apresentam Ipanema como dotada de potencialidade, mas com poucos resultados e uma pequena produção, o superintendente apresenta um quadro de completa desolação, resultante do abandono da fábrica em $1860^{303}$, em vista que sua visita foi realizada no início da gestão de Mursa e, portanto não pode ver os resultados desta direção ${ }^{304}$. Sobre a fábrica, que foi fechada em 1895, escreve:

\footnotetext{
${ }^{302}$ José Monteiro Salazar. Araçoiaba \& Ipanema.., op. cit., p. 126.

303 "Em busca de um parecer conclusivo, o Governo nomeou o engenheiro Guilherme Schuch de Capanema, em 1863, para que realizasse também um estudo minucioso do estabelecimento. No relatório que elaborou sobre a companhia, Capanema chamou atenção, inicialmente, para a ausência de uma clara definição dos limites territoriais da fábrica e para os conflitos decorrentes deste fato, visto que, por má índole ou desconhecimento, sitiantes haviam transformado parte das matas pertencentes ao estabelecimento em áreas pastoris ou de cultivo agrícola. As invasões eram, na verdade, fruto do abandono em que caiu a fábrica após a desativação, em 1860. Segundo atestou o encarregado pela fábrica no período 1860-1865, o tenente reformado Francisco Antonio Dias, os repasses não eram suficientes para o custeio do lugar e tampouco havia trabalhadores especializados, passando Ipanema por situações embaraçosas". Nilton Pereira dos Santos. A fábrica de ferro São João de Ipanema..., op. cit., p. 62.

304 "Foi a guerra do Paraguai que determinou anular-se esse plano [do estabelecimento de uma usina metalúrgica em Mato Grosso], pela impossibilidade de se dispor da navegação do rio, e restaurar o trabalho em Ypanema, sob as vistas do então capitão de engenheiros, o Dr. Joaquim de Sousa Mursa, cuja direção, apesar de seus defeitos técnicos numerosos, ainda representa o período áureo daquele estabelecimento". João Pandiá Calógeras. O ferro..., op. cit., p. 93.

Sobre as conseqüências da Guerra do Paraguai na política governamental para a Fábrica de Ipanema considera Nilton Pereira Santos: "Os principais autores que estudaram a fábrica Ipanema afirmaram que o período 1865-1870 foi próspero para o estabelecimento em virtude da Guerra contra o Paraguai. [...] Contudo, os relatórios e ofícios enviados pela fábrica ao ministro da Guerra durante os anos do conflito mostram uma realidade bem diferente. Entre 1865 e 1870 o estabelecimento amargou problemas crônicos como fornecimento de combustível, disponibilidade de mão-de-obra especializada, falta de maquinários e lentidão no repasse das subvenções e, portanto, não houve produção regular de ferro. [...] Portanto, mesmo que o Governo, a partir de 1865 , tivesse adotado uma nova postura em relação à Ipanema, que passou a ser vista como estratégica para o Estado, sobretudo pela possibilidade de fornecer 'projéteis ao Exército e Marinha, canhões de ferro fundido e de aço, e armas brancas', várias razões levaram o Ministério da Guerra a protelar o restauro da fábrica, uma vez que havia muitos obstáculos ao desenvolvimento da companhia e a
} 
"Mas, que desolação em redor de nós! que uivar do vento a cada lado da grande morada! que fragmentos rudes de edifícios antigamente bem construídos! que buracos deploráveis onde antes estavam os aparelhos das ressonantes forjas, e crepitavam as luminosas labaredas das fundições! Tudo despido e morto!"305.

A localização de inúmeros recursos e potencialidades de cultivo e extração é avaliada como um agravante para o quadro de negligência e o estado das instalações da fábrica, transformadas em ruínas. Com relação às riquezas afirma:

"Quando saímos às seis horas da manhã para visitar a famosa fábrica de Ypanema, distante algumas cinco léguas (sic), admirava muito o respeito do caráter do lugar que procurávamos. Tantas vezes tinha ouvido falar das ricas minas de ferro ali existentes, sem poder formar qualquer idéia do distrito; mas figurando a aparência geral que terras minerais apresentam, e das quais na Inglaterra já tenho visto muitas, supus que fosse Ypanema mais ou menos parecida com elas, e que havíamos de colocar-nos para o resto do dia e da noite em um lugar seco, árido e estéril! Mas em vez de achar terras estéreis caminhei sobre ricos pastos, embora muito desiguais na sua superfície; coberto de gato; os únicos objetos secos e áridos que vi, sendo os grandes resíduos de um estabelecimento abandonado, e mesmo desmanchado [...] Todavia ali a natureza ainda é riquíssima! riquíssima não só no mineral, mas igualmente no vegetal. Até a terra por toda a extensão é uma terra roxa, e ferruginosa, que produz o café; os Matos (sic), os pastos e a vegetação inteira é viçosa!"306.

Os norte-americanos também consideraram a região extremamente fértil, e, apropriada para o cultivo agrícola. Quando a visitavam, o Major Mereweather disse a Aubertin: "Dê-nos apenas este pedaço (indicando um lugar já roçado em que estamos) para plantar o nosso algodão e milho, e mando vir a nossa família sem sair da Província”307.

O britânico, tal como fazia com as amostras de algodão que coletava nas terras paulistas e enviava para análise na Associação para o Suprimento do Algodão de Manchester, retirou amostrar de algumas substâncias ao redor da fábrica para o estudo na Inglaterra e diz: "Já pelo último paquete mandei para Londres amostra de ferro e de cal, e chamei atenção especial para as varias capacidades importantíssimas da Ipanema",308.

Para o superintendente, os fazendeiros tinham dificuldade para escoar sua produção algodoeira devido à falta de estradas de ferro e melhores caminhos. Quando houve o

saída mais rápida de seus produtos, como exigia um conflito daquelas proporções”. Nilton Pereira dos Santos. A fábrica de ferro São João de Ipanema..., op. cit., p. 69-70 e 74.

${ }^{305}$ J. J. Aubertin. Onze dias de viagem na Província de São Paulo..., op. cit., p. 12.

${ }^{306}$ Ibidem, p. 10-12.

${ }^{307}$ Ibidem, p. 12.

${ }^{308}$ Ibidem, p. 13. 
aumento da produção no auge da procura pela matéria-prima, o porto de Santos não estava dotado de uma estrutura para que se comercializasse direto com os compradores. E toda a riqueza da região da Fábrica de Ipanema e sua construção em uma ótima localização eram negligenciadas.

Desta forma, se para Mawe e Pink a explicação se fundamenta em uma população negligente, e com Kidder, além deste fator, se soma a má administração pública; na segunda metade do século XIX, marcada pelo crescimento paulista e sua inserção no cenário comercial mundial, o desenvolvimento possível é limitado pela falta de infraestrutura que não foi prevista pela elite provincial e imperial, em decorrência da ausência de investimentos adequados. Se antes a displicência atrofiava o crescimento da produção e a exploração dos recursos, agora as realizações são limitadas por um novo fator ${ }^{309}$.

\footnotetext{
${ }^{309}$ Outros fatores são apresentados por Elizabeth de Camargo Mendes como causas do atraso brasileiro no oitocentos: "o atraso do Brasil, segundo os viajantes, deriva do fato de, além de ter sido uma colônia durante séculos, ser uma sociedade escravista. Para eles, este atraso se evidencia no fato de revelar abertamente que a riqueza advinha da exploração do trabalho alheio, que o Estado era um organismo político dos senhores, que a cultura era monopólio de uma classe, que a religião, descaradamente, um instrumento ideológico e que o ócio dos senhores era a contrapartida da atividade dos escravos". Elizabeth de Camargo Mendes. Os viajantes no Brasil: 1808-1822. Dissertação de mestrado. Departamento de História/Faculdade de Filosofia, Letras e Ciências Humanas/Universidade de São Paulo, 1981, p. 159. [Grifos da autora].
} 


\section{Considerações finais:}

Este trabalho tem como objetivo compreender como nos relatos de viagem se faz presente a ótica econômica e utilitarista, a qual agrega valor monetário e de uso aos elementos naturais pertencentes às localidades por onde passavam, filtrando potencialidades e capacidades de extração pelo homem.

Os relatos analisados foram Viagens ao interior do Brasil, principalmente aos distritos do ouro e dos diamantes (1812) de John Mawe; o Diário de uma viagem através das províncias do Rio de Janeiro e São Paulo. Brasil. América do Sul, escrito por Edmund Pink, que teve a primeira edição nacional em 2000; Reminiscências de viagens $e$ permanência nas Províncias do Sul do Brasil: Rio de Janeiro e Província de São Paulo: compreendendo notícias históricas e geográficas do Império e das diversas províncias (1845) de Daniel Parish Kidder, que juntamente com James Cooley Fletcher elabora a obra O Brasil e os brasileiros (Esboço histórico e descritivo) [1857]; e de autoria de J. J. Aubertin Onze dias de viagem na Província de São Paulo com os Srs. Americanos Drs. Gastón e Shaw, e Major Mereweather. 1865. Carta dirigida ao Illm. e Exm. Sr. Barão de Piracicaba (1866).

A visita destes viajantes a terras paulistas faz parte do contexto da transferência da Família Real Portuguesa para suas possessões americanas, porque se até então o território era protegido da cobiça e da presença de forasteiros, após 1808 os viajantes contaram com a permissão régia para percorrê-lo.

Devido às relações entre Portugal e Inglaterra, a última detinha a hegemonia econômica nas terras luso-brasileiras. Os súditos de Sua Majestade Imperial Britânica eram presença constante no cenário.

Se a Inglaterra intencionava permanecer em sua posição preponderante, os Estados Unidos almejavam desafiar este poderio, obter tratados comerciais e fortalecer as relações econômicas com o Brasil, e para isso se valeram das brechas na presença e ação inglesa. Concomitante a vinda dos viajantes britânicos há a dos norte-americanos.

A instalação da Corte no Centro-Sul do território da América Portuguesa trouxe a centralização política para a região, e estes viajantes durante sua permanência na capital carioca viajaram pontualmente para a Capitania e depois Província de São Paulo, com exceção de Aubertin que estava a serviço da Estrada de Ferro de São Paulo e também se preocupou com a região algodoeira paulista. 
John Mawe esteve na Capitania paulista entre o final de 1807 e início de 1808, partindo para o Rio de Janeiro assim que soube da chegada da Família Real a procura de contatos e contratos junto à Corte. Seu compatriota, o comerciante Edmund Pink também esteve em São Paulo, e sua viagem realizada durante o ano de 1823 teve a finalidade de percorrer os distritos açucareiros.

J. J. Aubertin algumas décadas após também se estabeleceu nessas paragens, e em 1865 empreendeu uma viagem pela região algodoeira paulista para analisar seu desenvolvimento e possibilidades de implantação e de crescimento. Nesta ocasião acompanhou um grupo de norte-americanos que estudavam a possibilidade de imigrarem com outros compatriotas devido à crise na lavoura algodoeira nos Estados Unidos, em especial nos estados do sul, em decorrência da Guerra Civil ocorrida entre 1861-1865.

A excursão de Aubertin esteve relacionada ao conflito, porque com os problemas internos norte-americanos houve a interrupção do fornecimento de algodão para a Inglaterra, que no período estava com sua importante indústria têxtil em franco desenvolvimento. Para evitar o colapso do sistema, os ingleses se lançaram pelo mundo em busca de regiões nas quais o algodão pudesse ser plantado e fossem capazes de se tornar mercado fornecedor.

Os norte-americanos Daniel Parish Kidder e James Cooley Fletcher visitaram São Paulo com intenções missionárias, e distribuíram exemplares da Bíblia pelas localidades onde estiveram. $\mathrm{O}$ último tinha também o escopo de estreitar as relações econômicas e culturais entre o Brasil e os Estados Unidos.

Ao descreveram as localidades que viam os viajantes se valeram de diferentes fontes e de material iconográfico. A presença destes elementos proporciona ao leitor o aprofundamento dos temas abordados, e as imagens, tal como as informações escritas, fornecem uma leitura da realidade paulista. Em nosso trabalho mapas, ilustrações e apontamentos foram abordados comparativamente e entendidos como parte do sentido dos relatos.

Apesar de cada um dos viajantes terem distintos objetivos, através da leitura dos relatos notamos que eles têm em comum uma ótica econômica e utilitarista, e vislumbram e descrevem as paragens encontradas através de modelos e parâmetros embasados na veneração ao trabalho, na concepção linear do tempo e exaltação das inovações técnicas. Condenavam o ócio e a preguiça, consideradas males sociais e que deveriam ser corrigidas, 
por exemplo, através da imigração e a vinda de novos habitantes, sem os vícios da população aqui existente.

Para os viajantes ingleses e norte-americanos as potencialidades de crescimento e enriquecimento paulista não são empregadas em sua capacidade máxima, de forma que limitam o seu desenvolvimento econômico. Regina Horta Duarte sintetiza este quadro nos seguintes termos: "O decorrer do século XIX parece ter assistido a um crescente otimismo dos europeus em relação a si próprios e à cultura da qual participavam. Evolução, progresso, produção e civilização são motivos de orgulho a ponto da incompreensão e intolerância de qualquer outra sociedade em que os homens pudessem viver diferentemente. [...] Na verdade, eles não apenas postularam tal superioridade, mas também apresentavam seu modelo de sociedade como o único realmente factível e propriamente humano" 310 .

\footnotetext{
${ }^{310}$ Regina Horta Duarte. Olhares estrangeiros. Viajantes no vale do rio Mucuri. Revista Brasileira de História. São Paulo, v. 22, nª 44, 2002, p. 278.
} 


\section{Fontes:}

Os relatos de viagem contam com diversas edições. Utilizamos como fonte para citações as edições brasileiras contemporâneas pela facilidade de acesso, com exceção da obra de J. J. Aubertin em que usamos o exemplar de 1866.

AUBERTIN, J. J. Onze dias de viagem na Província de São Paulo com os Srs. Americanos Drs. Gastón e Shaw, e o Major Mereweather. 1865. Carta dirigida ao Illm. e Exm. Sr. Barão de Piracicaba. São Paulo: Typ. Allemã de H. Schroeder, 1866. (1ª edição).

FLETCHER, J. C.; KIDDER, D. P. O Brasil e os brasileiros (Esboço histórico e descritivo). Trad. Elias Dolianiti. São Paulo: Companhia Editora Nacional, 1941, 2. vols. ( $1^{\mathrm{a}}$ edição 1857$)$.

KIDDER, Daniel Parish. Reminiscências de viagens e permanência nas Províncias do Sul do Brasil: Rio de Janeiro e Província de São Paulo: compreendendo notícias históricas e geográficas do Império e das diversas províncias. Trad. Moacir Vasconcelos. Belo Horizonte: Ed. Itatiaia; São Paulo: Edusp, 1980. (1ª edição 1845).

MAWE, John. Viagens ao interior do Brasil, principalmente aos distritos do ouro e dos diamantes. Trad. Selena Benevides Viana. Rio de Janeiro: Zelio Valverde, 1944. ( $1^{\mathrm{a}}$ edição 1812).

Viagens ao interior do Brasil. Trad. Selena Benevides Viana. Belo Horizonte: Ed. Itatiaia; São Paulo: Edusp, 1978.

PINK, Edmund. A São Paulo de Edmund Pink. Trad. e transcr. Cristina Antunes. São Paulo: CBA, 2000. (1823 - $1^{\text {a }}$ edição 2000).

\section{Fontes Complementares:}

AGASSIZ, Luiz e Elizabeth. Viagem ao Brasil: 1865-1866. Trad. João Etienne Filho. Belo Horizonte: Ed. Itatiaia; São Paulo: Edusp, 1975.

ANDRADA, Martim Francisco Ribeiro de. Diário de uma viagem mineralógica pela província de São Paulo no ano de 1805. Jornal do Instituto Histórico e Geográfico Brasileiro. 2. ed. Rio de Janeiro: Typographia de João Ignácio da Silva, 1869, tomo IX, p. 527-548.

ANDREWS, C.C. Brazil. Its condition and prospects. New York: D. Applenton and Company, 1887.

AVÉ-LALLEMANT, Robert. Viagens pelas províncias de Santa Catarina, Paraná e São Paulo (1858). Trad. Teodoro Cabral. Belo Horizonte: Ed. Itatiaia; São Paulo: Edusp, 1980.

BALL, John. Notes of a naturalist in South America. London: Kegan Paul, Trench \& CO., I, Paternoster Square, 1887.

BEYER, Gustavo. Viagem a São Paulo no verão de 1813. Trad. Alberto Loëfgren. 2. ed. Campinas (SP): PucCampinas, 1992. 
BUNBURY, Charles James Fox. Viagem de um naturalista inglês ao Rio de Janeiro e Minas Gerais: 1833-1835. Trad. Helena Garcia de Souza. Belo Horizonte: Ed. Itatiaia; São Paulo: Edusp, 1981.

BURTON, Richard Francis. Viagem do Rio de Janeiro a Morro Velho. Trad. David Jardim Júnior. Belo Horizonte: Itatiaia; São Paulo: Edusp, 1976.

- Viagem de canoa de Sabará ao Oceano Atlântico. Trad. David Jardim Júnior. Belo Horizonte: Itatiaia; São Paulo: Edusp, 1977.

CALDCLEUGH, Alexander. Travels in South America, during the years 1819-20-21: containing an account of the present state of Brazil, Buenos Aires. London: John Murray, 1867. 2. vols.

DAVATZ, Thomas. Memórias de um colono no Brasil (1850). Trad. Sérgio Buarque de Holanda. São Paulo: Livraria Martins, 1941.

D’ORBIGNY, Alcides Dessalines. Viagem pitoresca através do Brasil. Trad. David Jardim. Belo Horizonte: Ed. Itatiaia; São Paulo: Edusp, 1976.

ESCHWEGE, Wilhelm. Pluto Brasiliensis. Belo Horizonte: Ed. Itatiaia; São Paulo: Edusp, 1979. 2. vols.

EWBANK, Thomas. A vida no Brasil; ou, Diário de uma visita à terra do cacaueiro e das palmeiras, com um apêndice contendo ilustrações das artes sul-americanas antigas. Trad. Jamil Almansur Haddad. Belo Horizonte: Ed. Itatiaia; São Paulo: Edusp, 1976.

GARDNER, George. Viagem ao interior do Brasil, principalmente nas províncias do Norte e nos distritos do ouro e do diamante durante os anos de 1836-1841. Trad. Milton Amado. Belo Horizonte: Ed. Itatiaia; São Paulo: Edusp, 1975.

GRAHAM, Maria. Diário de uma viagem ao Brasil. Trad. A. J. L. Belo Horizonte: Itatiaia; São Paulo: Edusp, 1990.

JUZARTE, Teotônio José. Diário da navegação. Jonas Soares de Souza, Miyoko Makino (orgs.). São Paulo: Edusp; Imprensa Oficial do Estado, 2000.

HADFIELD, William. Brazil and the River Plate in 1868: showing the progress of those countries since his former visit in 1853. London: Bates, Hendy and CO., 1869.

HARTT, Charles Frederick. Geologia e geografia física do Brasil. Trad. Edgard Süssekind de Mendonça e Elias Dolianiti. São Paulo, Rio de Janeiro, Recife, Porto Alegre: Cia. Editora Nacional, 1941.

KIDDER, Daniel Parish. São Paulo in 1839. São Paulo: Sociedade Brasileira de Cultura Inglesa, 1969.

KINDERSLEY, Jemima. Mulheres viajantes no Brasil (1754-1820): antologia de textos (Jemima Kindersley, Elizabeth Henrietta Macquarie, Rose Freycinet). Trad. e org. Jean Marcel Carvalho França. Rio de Janeiro: José Olympio, 2008.

LANDSEER, Charles. Landseer. Editor Cândido Guinle de Paula Machado. Textos Alberto Rangel. São Paulo: Lanzara S.A., 1972.

LUCCOCK, John. Notas sobre o Rio de Janeiro e partes meridionais do Brasil. Trad. Milton da Silva Rodrigues. Belo Horizonte: Ed. Itatiaia; São Paulo: Edusp, 1975.

MAY, William Henry. Diário de uma viagem da Baía de Botafogo à cidade de São Paulo (1810). Trad. Jean Marcel de Carvalho França. Rio de Janeiro: José Olympio, 2006. 
SAINT-HILAIRE, Auguste de. Viagem à Província de São Paulo. Trad. Regina Reis Junqueira. Belo Horizonte: Ed. Itatiaia; São Paulo: Edusp, 1976.

. Segunda viagem do Rio de Janeiro a Minas Gerais e a São Paulo, 1822. Trad. Vivaldi Moreira. Belo Horizonte: Ed. Itatiaia; São Paulo: Edusp, 1974.

SILVA, Danuzio Gil Bernardino (org.). Os diários de Langsdorff. Trad. Márcia Eggs e outros. Fiocruz: Rio de Janeiro; Campinas (SP): Associação Internacional de Estudos Landsdorff, 1997, vol. 1. Rio de Janeiro e Minas Gerais - 8 de maio de 1824 a 17 de fevereiro de 1825; vol. 2. 26 de agosto de 1825 a 22 de novembro de 1826 .

SMITH, Herbert H. Do Rio de Janeiro a Cuiabá. Notas de um naturalista (Com capítulo de Carlos von den Steinen sobre a capital do Matto Grosso). São Paulo: Companhia Melhoramentos/Weiszflog Irmãos Incorporados, 1922.

SPIX, Johann von; MARTIUS, Carl von. Viagem pelo Brasil. 1817-1820. Trad. Lúcia Furquim Lahmeyer. 2. ed. São Paulo: Melhoramentos, s/d.

TSCHUDI, Johann Jakob von. Viagens às províncias do Rio de Janeiro e São Paulo. Trad. Eduardo de Lima Castro. Belo Horizonte: Ed. Itatiaia; São Paulo: Edusp, 1980.

WELLS, James W. Explorando e viajando três milhas através do Brasil - do Rio de Janeiro ao Maranhão. Trad. Myriam Ávila. Introd. Christopher Hill. Belo Horizonte: Fundação João Pinheiro, Centro de Estudos Históricos e Culturais, 1995, 2. vols.

\section{Cartografia:}

COSTA, Rufino José Felizardo e. Planta da Imperial Cidade de São Paulo, 1841. In.: LAGO, Pedro Côrrea do. Iconografia paulistana: do século XIX. 2. ed. rev. e ampl. São Paulo: Capivara, 2003.

MENDES, Candido. Atlas do Império do Brazil (1868). Rio de Janeiro: Arte \& História, Livros e Edições, 2000. Mapa do Império do Brazil (1868): II; Mapa da Província de São Paulo (1868): XVII.

\section{Bibliografia:}

ABREU, Jean Luiz Neves. Fronteira aberta: território e natureza nas memórias, corografias e relatos de viajantes em Minas Gerais no século XIX. Revista de Economia Política e História Econômica, São Paulo: Núcleo de Economia Política e História Econômica (NEPHE), no 17, ano 6, junho de 2009. (Disponível em http://rephe01.googlepages.com).

ALMEIDA, Aluísio de. Vida cotidiana da Capitania de São Paulo (1722-1822). Excertos de uma obra completa. In.: MOURA, Carlos Eugênio Marcondes de (org.). Vida cotidiana em São Paulo no século XIX: memórias, depoimentos, evocações. São Paulo: Ateliê Editorial: Fundação Editora da Unesp: Imprensa Oficial do Estado: Secretaria de Estado da Cultura, 1998. 
ALMEIDA, Antonia Fernanda Pacca de. Desafio americano à preponderância britânica no Brasil: 1808-1850. Tese de doutorado. Departamento de História/Faculdade de Filosofia, Letras e Ciências Humanas/Universidade de São Paulo, 1970.

ARAÚJO FILHO, José R. de. O minério de ferro no Brasil no século XIX. In.: HOLANDA, Sérgio Buarque de (org.). História Geral da Civilização Brasileira. O Brasil monárquico: declínio e queda do império. 5. ed. Rio de Janeiro: Bertrand Brasil, 1995.

ARAÚJO, Maria Lucília Viveiros. Os caminhos da riqueza dos paulistanos na primeira metade do oitocentos. São Paulo: Hucitec: FAPESP, 2006.

ARRUDA, José Jobson de Andrade. Uma colônia entre dois impérios: a abertura dos portos brasileiros. 1800-1808. Bauru (SP): EDUSC, 2008.

BANDEIRA, Luiz Alberto Moniz. Presença dos Estados Unidos no Brasil. Rio de Janeiro: Civilização Brasileira, 2007.

BARREIRO, José Carlos. Imaginário e viajantes no Brasil do século XIX: cultura e cotidiano, tradição e resistência. São Paulo: Editora UNESP, 2002.

O cotidiano e o discurso dos viajantes: criminalidade, ideologia e luta social no Brasil do século XIX. São Paulo. Tese de doutorado. Departamento de História/Faculdade de Filosofia, Letras e Ciências Humanas/Universidade de São Paulo, 1988.

BASTOS, Elide Rugai. Os descendentes de Prometeu. Folha de S. Paulo, São Paulo, 12 abril 2000. Caderno Mais, p. 18-19.

BIVAR, Diogo Soares da Silva de. Apêndice à Crônica do ano de 1842. Revista do Instituto Histórico e Geográfico Brasileiro. 3. ed. Rio de Janeiro: Typographia Universal Lammert \& C., 1885, tomo 5, p. 413-430.

BJÖRKMAN, Göran. Dr. Gustavo Beyer. Esboço biográfico extraído e vertido da Sveriges Läkarehistoria (História dos Médicos da Suécia) de J. F. Sacklén. Revista do Instituto Histórico e Geográfico de S. Paulo. São Paulo: Typographia do Diário Oficial, 1911, vol. XIII, p. 435-440.

BLAJ, Ilana. A trama das tensões: o processo de mercantilização de São Paulo colonial (1681-1721). São Paulo: Humanitas Publicações FFLCH/USP; FAPESP, 2002.

BORGES, Maria Eliza Linhares. Imagens da nação brasileira. Locus: revista de história, Juiz de Fora-MG: EDUFJF, v. 7, n. 1, pp. 9-25, 2001.

BORGES, Urquiza Maria. A cidade de São Paulo (meados do século XIX). História. São Paulo: Fundação para o Desenvolvimento da UNESP, 1998/1999, p. 45-69.

BOXER, Charles. O império marítimo português (1415-1825). 2. reimp. Trad. Anna Olga de Barros Barreto. São Paulo: Companhia das Letras, 2002.

BRASIL. Secretaria de Estado dos Negócios do Império e Estrangeiros. O Conselho de Estado e a política externa do Império: consulta da seção dos negócios estrangeiros (1858-1862). Rio de Janeiro: CDHH; Brasília: FUNAG, 2005.

BRESCIANI, Maria Stella (org.). Imagens da cidade: séculos XIX e XX. São Paulo: Marco Zero-ANPUH/SP-FAPESP, 1994.

Imagens de São Paulo: estética e cidadania. In.: FERREIRA, Antonio Celso; LUCA, Tânia Regina; IOKOI, Zilda Grícoli. Encontros com a História: 
percursos históricos e historiográficos de São Paulo. São Paulo: ANPUH/FAPESP/Ed. Unesp, 1999.

BRUNO, Ernani da Silva. História e tradições da cidade de São Paulo. Rio de Janeiro: José Olympio, 1953, 3. vols.

. Viagem ao país dos paulistas. Ensaio sobre a ocupação da área vicentina e a formação de sua economia e de sua sociedade nos tempos coloniais. Rio de Janeiro: José Olympio, 1966.

CALDEIRA, Jorge. A nação mercantilista. 2. reimp. São Paulo: Ed. 34, 1999.

CAMPOS, Eudes. São Paulo: desenvolvimento urbano e arquitetura sob o Império. In: PORTA, Paula (org.). História da Cidade de São Paulo: a cidade no Império. São Paulo: Paz e Terra, 2004, vol. 2.

CAMPOS, Pedro Moacyr. Imagens do Brasil no Velho Mundo. In.: HOLANDA, Sérgio Buarque de (org.). História geral da civilização brasileira: o Brasil monárquico: o processo de emancipação. 2. ed. São Paulo: Difusão Européia do Livro, 1965, vol. 1.

CANABRAVA, Alice P. O algodão em São Paulo: 1861-1875. 2. ed. São Paulo: Ed. T. A. Queiroz, 1984.

. A grande lavoura. In.: HOLANDA, Sérgio Buarque de (org.). História Geral da Civilização Brasileira: O Brasil monárquico: declínio e queda do Império. 5. ed. Rio de Janeiro: Bertrand Brasil, 1995.

CAVENAGHI, Airton José. O território paulista na iconografia oitocentista: mapas, desenhos e fotografias. Análise de uma herança cotidiana. Anais do Museu Paulista: História e Cultura Material, São Paulo, v. 14, n ${ }^{\circ}$ 1. jan./jun. 2006. (Disponível em www.scielo.br).

CHARLOT, Monica; MARX, Roland (orgs.). Londres: 1851-1901: a Era Vitoriana ou o triunfo das desigualdades. Rio de Janeiro: Jorge Zahar Ed., 1993.

COMMAGER, Henry Steele; MORISON, Samuel Eliot. História dos Estados Unidos. São Paulo: Edições Melhoramentos, s/d, tomo 2.

CORRÊA, Dora Shellard. Historiadores e cronistas e a paisagem da colônia Brasil. Revista Brasileira de História, São Paulo: ANPUH; Humanitas Publicações FFLCH/USP, v. 26, n. 51, jan./jun. 2006.

COSTA, Christina Rostworowski da. O Príncipe Maximiliano de Wied-Neuwied e sua Viagem ao Brasil (1815-1817). Dissertação de mestrado. Departamento de História/Faculdade de Filosofia, Letras e Ciências Humanas/Universidade de São Paulo, 2008.

COSTA, Marcos. Para uma nova história. Textos de Sérgio Buarque de Holanda. São Paulo: Editora Fundação Perseu Abramo, 2004.

COSTA, Wanderlei Messias da. Geografia política e geopolítica: discurso sobre o território e o poder. 2. ed. São Paulo: Edusp, 2008.

CRUZ, Ana Lúcia Rocha Barbalho da. As viagens são os viajantes: dimensões identitárias dos viajantes naturalistas brasileiros do século XVIII. História: questões e debates, Curitiba, PR: Ed. UFPR, v. 19, n. 36, jan./jun. 2002, p. 61-98. 
DEAECTO, Marisa Midori. No Império das Letras: circulação e consumo de livros na São Paulo oitocentista. Tese de doutorado. Departamento de História/Faculdade de Filosofia, Letras e Ciências Humanas/Universidade de São Paulo. São Paulo, 2005.

DIAS, Maria Odila L. da Silva. A interiorização da metrópole e outros estudos. 2. ed. São Paulo: Alameda, 2005.

São Paulo: Brasiliense, 1995.

Quotidiano e poder em São Paulo no século XIX. 2. ed.

DOM PEDRO II Imperador do Brasil. Viagens pelo Brasil: Bahia, Sergipe e Alagoas (1859-1860). 2. ed. Rio de Janeiro: Bom texto, Letras \& Expressões, 2003.

DOMINGUES, Ângela. Viagens de exploração geográfica na Amazônia em finais do século XVIII: política, ciência e aventura. Lisboa/Região Autônoma da Madeira: Imprensa de Coimbra /Secretaria Regional do Turismo, Cultura e Emigração/Centro de Estudos de História do Atlântico, 1991.

DUARTE, Regina Horta. Olhares estrangeiros. Viajantes no vale do rio Mucuri. Revista Brasileira de História, São Paulo: ANPUH; Humanitas Publicações FFLCH/USP, v. 22, n. 44, 2002, p. 267-288.

ELLIS, Myriam. A mineração no Brasil no século XIX. In.: HOLANDA, Sérgio Buarque de (org.). História Geral da Civilização Brasileira. O Brasil monárquico: declínio e queda do império. 5. ed. Rio de Janeiro: Bertrand Brasil, 1995.

FAZENDA, Vieira. Gustavo Beyer. Viajante Sueco (1813). Revista do Instituto Histórico e Geográfico de S. Paulo. São Paulo: Typ. do 'Diário Oficial', 1908, vol. XII, p. 665-669.

FERNANDES, Luiz Estevam; MORAIS, Marcus Vinícius. Os EUA no século XIX. In.: KARNAL, Leandro [et alli]. História dos Estados Unidos: das origens ao século XXI. São Paulo: Contexto, 2007.

FONSECA, Vera Maria. Invertebrados fósseis do Museu Nacional: um legado de Hartt. In.: GEBARA, Alexsander Lemos de Almeida. Hartt: expedições pelo Brasil Imperial. 1865-1878. São Paulo: Metalivros, 2001, pp. 232-235.

FOUCAULT, Michel. Sobre a geografia. In.: FOUCAULT, Michel. Microfisica do poder. 15. ed. Rio de Janeiro: Edições Graal, 2000.

FRANCO, José Luiz de Andrade; DRUMMOND, José Carlos. Cândido de Mello-Leitão: as ciências biológicas e a valorização da natureza e da diversidade da vida. História, Ciência, Saúde - Manguinhos, Rio de Janeiro, vol. 14, n. 4, out./dez. 2007. (Disponível em www.scielo.br).

FRANÇA, Jean Marcel Carvalho. Apresentação: Viajantes estrangeiras no Brasil. In.: KINDERSLEY, Jemima. Mulheres viajantes no Brasil (1754-1820): antologia de textos (Jemima Kindersley, Elizabeth Henrietta Macquarie, Rose Freycinet). Trad. e org. Jean Marcel Carvalho França. Rio de Janeiro: José Olympio, 2008.

Apresentação. In.: MAY, William Henry. Diário de $\overline{u m a}$ viagem da Baía de Botafogo à cidade de São Paulo (1810). Rio de Janeiro: José Olympio, 2006.

FREITAS, Marcus Vinicius de. Charles Frederick Hartt, um naturalista no império de Pedro II. Belo Horizonte: Ed. UFMG, 2002. 
Paulo: Metalivros, 2001.

. Hartt: expedições pelo Brasil Imperial. 1865-1878. São

FREYRE, Gilberto. Ingleses no Brasil. Aspectos da influência britânica sobre a vida, a paisagem e a cultura do Brasil. Prefácio Octavio Tarquínio de Souza. Rio de Janeiro: Livraria José Olympio Editora, 1948.

. Prefácio da edição brasileira. In.: LIMA, Oliveira. Formação histórica da nacionalidade brasileira. 3. ed. Rio de Janeiro: Topbooks; São Paulo: Publifolha, 2000, pp. 9-13.

. Sobrados e mucambos. 12. ed. Rio de Janeiro: Record, 2000.

GARCIA, Rodolfo. Richard Grandsire: viajante francês no Brasil. Revista do Instituto Histórico e Geográfico Brasileiro. Rio de Janeiro: Imprensa Nacional, 1925, vol. 144, tomo 90 , p. 539-554.

GASPAR, Lúcia. Viajantes em terras brasileiras: documentos existentes no acervo da Biblioteca Central Blanche Knopf. In.: FUNDAÇÃO JOAQUIM NABUCO. (Disponível em www.fundaj.gov.br/geral).

GEBARA, Alexsander Lemos de Almeida. A experiência do contato. As descrições populacionais de Richard Francis Burton. Dissertação de mestrado. Departamento de História/Faculdade de Filosofia, Letras e Ciências Humanas/Universidade de São Paulo. São Paulo, 2001.

. A África presente no discurso de Richard Francis Burton. Uma análise da construção de suas representações. Tese de doutorado. Departamento de História/Faculdade de Filosofia, Letras e Ciências Humanas/Universidade de São Paulo. São Paulo, 2006.

GERODETTI, João Emilio; CORNEJO, Carlos. Lembranças do Brasil: as capitais brasileiras nos cartões-postais e álbuns de lembrança. São Paulo: Solaris Edições Culturais, 2004.

GLEZER, Raquel. Chão de terra e outros ensaios sobre São Paulo. São Paulo: Alameda, 2007. [et alli]. São Paulo espaço e história. São Paulo: LCTE Editora, 2008.

. Visões de São Paulo. In.: BRESCIANI, Maria Stella (org.). Imagens da cidade: séculos XIX e XX. São Paulo: Marco Zero-ANPUH/SP-FAPESP, 1994.

GOMES, Ângela de Castro. Gilberto Freyre e Oliveira Lima: Casa Grande e Senzala e o contexto historiográfico do início do século XX. História, São Paulo: Fundação Editora da UNESP, v. 20, p. 29-44, 2001.

GRANDE Enciclopédia Portuguesa e Brasileira. Lisboa; Rio de Janeiro: Editorial Enciclopédia, s/d, vol. 3.

GUIMARÃES, Manoel Luís Salgado. Nação e civilização nos trópicos: o Instituto Histórico e Geográfico Brasileiro e o projeto de uma história nacional. Estudos Históricos, Rio de Janeiro: Edições Vértice, n. 1, p. 5-27, 1988.

HARDMAN, Francisco Foot. Trem fantasma: a ferrovia Madeira - Mamoré e a modernidade na selva. 2. ed. rev. e ampl. São Paulo: Companhia das Letras, 2005.

HOBSBAWN, Eric J. A era do capital, 1848-1875. Rio de Janeiro: Paz e Terra, 1996. 
HOLANDA, Sérgio Buarque de. Para uma nova história. Textos de Sérgio Buarque de Holanda. Marcos Costa (Org.). São Paulo: Editora Fundação Perseu Abramo, 2004.

. A herança colonial: sua desagregação. In.: HOLANDA, Sérgio Buarque de (org.). História geral da civilização brasileira: o Brasil monárquico: o processo de emancipação. 2. ed. São Paulo: Difusão Européia do Livro, 1965, vol. 1.

São Paulo. In.: HOLANDA, Sérgio Buarque (org.). História Geral da Civilização Brasileira. O Brasil monárquico: dispersão e unidade. 6. ed. Rio de Janeiro: Bertrand Brasil, 1995.

$\mathrm{HORCH}$, Rosemarie Érika. Álbuns de viajantes que estiveram no Brasil, na primeira metade do século XIX. Boletim Bibliográfico Biblioteca Mário de Andrade, São Paulo, v. 41, n. 3-4, pp. 48-149, jul. dez. 1980. (Separata do Boletim).

IGLÉSIAS, Francisco. Os historiadores do Brasil: capitulos de historiografia brasileira. Rio de Janeiro: Nova Fronteira; Belo Horizonte: UFMG, IPEA, 2000.

JANCSÓ, István [et alii]. Cronologia de história do Brasil monárquico: 1808-1899. São Paulo: Humanitas, 2000.

KOK, Glória Porto. O sertão itinerante: expedições da capitania de São Paulo no século XVIII. São Paulo: Hucitec; FAPESP, 2004.

LAGO, Pedro Côrrea do. Iconografia paulistana: do século XIX. 2. ed. rev. e ampl. São Paulo: Capivara, 2003.

LE GOFF, Jacques; NORA, Pierre. História: novas abordagens. 3. ed. Rio de Janeiro: Francisco Alves, 1988.

Alves, 1976. História: novos objetos. Rio de Janeiro: Francisco

Francisco Alves, 1988.

História: novos problemas. 3. ed. Rio de Janeiro:

LEITE, Miriam Lifchitz Moreira; MOTT, Maria Lúcia de Barros. A condição feminina no Rio de Janeiro. Século XIX: antologia de textos de viajantes estrangeiros. São Paulo: HUCITEC, Edusp; Brasília: INL, Fundação Nacional Pró-Memória, 1984.

UFRJ, 1997. . Livros de viagem (1803-1900). Rio de Janeiro: Ed.

LESSA, Clado Ribeiro de. Introdução. In.: MAWE, John . Viagens ao interior do Brasil. Trad. Selena Benevides Viana. Belo Horizonte: Ed. Itatiaia; São Paulo: Edusp, 1978.

LIMA, Oliveira. As notas de viagem no Brasil, em 1813, de Gustavo Beyer. Revista do Instituto Histórico e Geográfico de S. Paulo. São Paulo: Typ. do 'Diário Oficial', 1908, vol. XII, p. 669-672.

. Dom João VI no Brasil. 4. ed. Rio de Janeiro: Topbooks, 2006.

. Formação histórica da nacionalidade brasileira. 3. ed. Rio de Janeiro: Topbooks; São Paulo: Publifolha, 2000.

. Quem era Gustavo Beyer. Revista do Instituto Histórico e Geográfico de S. Paulo. São Paulo: Typ. do 'Diário Oficial', 1908, vol. XII, p. 672-676.. 
LISBOA, Karen Macknow. Nova Atlântida ou o gabinete naturalista dos doutores Spix e Martius: natureza e civilização na viagem pelo Brasil (1817-1820). Dissertação de mestrado. Departamento de História/Faculdade de Filosofia, Letras e Ciências Humanas/Universidade de São Paulo. São Paulo, 1995.

Viajantes de língua alemã no Brasil. Olhares sobre a sociedade e a cultura (1893-1942). Tese de doutorado. Departamento de História/Faculdade de Filosofia, Letras e Ciências Humanas/ Universidade de São Paulo. São Paulo, 2002.

Olhares estrangeiros sobre o Brasil do século XIX. In.: MOTA, Carlos Guilherme (org.) Viagem incompleta: a experiência brasileira (15002000). 2. ed. São Paulo: Editora SENAC, 2000.

LÖFGREN, Alberto. O viajante sueco Gustavo Beyer. Revista do Instituto Histórico e Geográfico de S. Paulo. São Paulo: Typ. do 'Diário Oficial', 1912, vol. XIV, p. 71-76.

LUNA, Francisco Vidal; KLEIN, Herbert S. Evolução da sociedade e economia escravista de São Paulo, de 1750 a 1850. São Paulo: Edusp, 2005.

MAGNOLI, Demétrio. O corpo da pátria: imaginação geográfica e política externa no Brasil (1808-1912). São Paulo: Ed. UNESP: Moderna, 1997.

MANCHESTER, Alan K. Preeminência inglesa no Brasil. São Paulo: Brasiliense, 1973.

MATOS, Odilon Nogueira. Café e ferrovias: a evolução ferroviária de São Paulo e o desenvolvimento da cultura cafeeira. 4. ed. Campinas, São Paulo: Pontes, 1990.

. Uma visão diferente de São Paulo no início do século XIX.

Notícias bibliográficas e históricas, Campinas, SP: Ed. PUC-Campinas, n. 188, pp. 3-9, jan./mar. 2003.

MELLO, Evaldo Cabral de. O ovo de Colombo gilbertiano. Folha de S. Paulo, São Paulo, 12 abril 2000. Caderno Mais, p. 12-14.

Uma nova Lusitânia. In.: MOTA, Carlos Guilherme (org.). Viagem incompleta: a experiência brasileira (1500-2000). 2. ed. São Paulo: Editora SENAC, 2000.

MELlO-LEITÃO, Cândido de. A biologia no Brasil. São Paulo: Companhia Editora Nacional, 1937.

. A vida na selva. São Paulo: Companhia Editora Nacional, 1940.

Companhia Editora Nacional, 1941.

. História das expedições científicas no Brasil. São Paulo:

Editora Nacional, 1937.

. O Brasil visto pelos ingleses. São Paulo: Companhia

. Prefácio. In.: BATES, Henry Walter. O naturalista no Rio Amazonas. Trad. pref. e notas de Cândido de Mello-Leitão. São Paulo: Companhia Editora Nacional, 1944, vol. 1.

Companhia Editora Nacional, 1944

Vida maravilhosa dos animais. 2. ed. São Paulo: 
Editora Nacional, 1934.

. Visitantes do Primeiro Império. São Paulo: Companhia

MENDES, Elizabeth de Camargo. Os viajantes no Brasil: 1808-1822. Dissertação de mestrado. Departamento de História/Faculdade de Filosofia, Letras e Ciências Humanas/Universidade de São Paulo. São Paulo, 1981.

MENDONÇA, Edgard Süssekind. Notas bio-biográficas In.: J. C. FLETCHER; D. P. KIDDER. O Brasil e os brasileiros (Esboço histórico e descritivo). Trad. Elias Dolianiti. São Paulo: Companhia Editora Nacional, 1941, vol. 1.

MESGRAVIS, Laima. O viajante e a cidade (a vida no Rio de Janeiro através dos viajantes estrangeiros da primeira metade do século XIX). Tese de Livre Docência. Departamento de História/Faculdade de Filosofia, Letras e Ciências Humanas/Universidade de São Paulo. São Paulo, 1987. 2 vols.

MINDLIN, José. Viajantes no Brasil: viagem em torno dos meus livros. Estudos históricos: viagem e narrativa. Rio de Janeiro, nº 7, p. 35-54, 1991.

MONTESINHO, Antonio Roiz. Mappa corographico da Capitania de S. Paulo (17911792). In.: Collectanea de mappas da cartographia paulista antiga. Abrangendo nove cartas, de 1612 a 1837, reproduzidas da collecção do Museu Paulista e acompanhadas de breves commentarios. São Paulo: Companhia Melhoramentos de S. Paulo; Museu Paulista, 1922.

MORAES, Antonio Carlos Robert. Território e história no Brasil. São Paulo: Annablume, 2005.

MORAIS, Rubens Borba de. Introdução. In.: KIDDER, Daniel Parish. Reminiscências de viagens e permanência nas Províncias do Sul do Brasil: Rio de Janeiro e Províncias de São Paulo: compreendendo notícias históricas e geográficas do Império e das diversas províncias. Trad. Moacir Vasconcelos. Belo Horizonte: Ed. Itatiaia; São Paulo: Edusp, 1980.

MOREL, Marco. As transformações dos espaços públicos. Imprensa, atores políticos e sociabilidade na cidade imperial (1820-1840). São Paulo: HUCITEC, 2005.

MORSE, Richard. Formação histórica de São Paulo (de comunidade à metrópole). São Paulo: Difusão Européia do Livro, 1970.

MOURA, Carlos Eugênio Marcondes de (org.). Vida cotidiana em São Paulo no século XIX: memórias, depoimentos, evocações. São Paulo: Ateliê Editorial: Fundação Editora da Unesp: Imprensa Oficial do Estado: Secretaria de Estado da Cultura, 1998.

MOURA, Denise Aparecida Soares de. Economia, cultura e sociedade em São Paulo (1808-1850). Tese de doutorado. Departamento de História/Faculdade de Filosofia, Letras e Ciências Humanas/Universidade de São Paulo, 2002.

MÜLLER, Daniel Pedro. Ensaio d'um quadro estatístico da província de São Paulo: ordenado pelas leis municipais de 11 de abril de 1836 e 10 de março de 1837. 3. ed. facsimilar. São Paulo: Governo do Estado, 1978.

- Mappa corographico da Provincia de S. Paulo (1837). In.:

Collectanea de mappas da cartographia paulista antiga. Abrangendo nove cartas, de 1612 a 1837, reproduzidas da collecção do Museu Paulista e acompanhadas de breves commentarios. São Paulo: Companhia Melhoramentos de S. Paulo; Museu Paulista, 1922. 
NISBET, Robert. História da idéia de progresso. Brasília: Ed. UNB, 1985.

NOAL FILHO, Valter Antonio; FRANCO, Sérgio da Costa. Os viajantes olham Porto Alegre: 1754-1890. Santa Maria: Anaterra, 2004.

Alegre: 1890-1941. Santa Maria: Anaterra, 2004.

Os viajantes olham Porto

NOMURA, Hitoshi. Vultos da zoologia brasileira. Mossoró (RN): Escola Superior de Agricultura de Mossoró/Fundação Guimarães Duque, 1991, vol. 1, pp. 59-63.

NOVAIS, Fernando. Portugal e Brasil na crise do Antigo Sistema Colonial (1777-1808). 8. ed. São Paulo: Hucitec, 2006.

OBERACKER, Carlos. Viajantes, naturalistas e artistas estrangeiros. In.: HOLANDA, Sérgio Buarque (Org.) História geral da civilização brasileira: o Brasil monárquico. 2. ed. São Paulo: Difusão Européia do Livro, 1965, tomo. 2, v. 1.

OLIVEIRA, Maria da Glória. Traçando vidas de brasileiros distintos com escrupulosa exatidão: biografias, erudição e escrita da história na Revista do Instituto Histórico e Geográfico Brasileiro (1839-1850). História (São Paulo). Franca. v. 26, nº 1, 2007. (Disponível em www.scielo.br).

PALAZZO-ALMEIDA, Carmen Lícia. Entre mitos, utopias e razão: os olhares franceses sobre o Brasil (séculos XVI a XVII). Tese de doutorado. Departamento de História, Universidade de Brasília. Brasília, 1999.

PANDIÁ CALÓGERAS, João. O ferro, ensaio de história industrial. Revista do Instituto Histórico e Geográfico de São Paulo. São Paulo, 1904, vol. IX, p. 20-100.

PANTALEÃO, Olga. A presença inglesa. In.: HOLANDA, Sérgio Buarque de (org.). História Geral da Civilização Brasileira: O Brasil monárquico. 2. ed. São Paulo: Difusão Européia do Livro, 1965, vol. 1.

; CAMPOS, Pedro Moacyr. O reconhecimento do Império. In.: HOLANDA, Sérgio Buarque de (org.). História geral da civilização brasileira: o Brasil monárquico: o processo de emancipação. 2. ed. São Paulo: Difusão Européia do Livro, 1965, vol. 1.

PEREIRA, Valter Pires. A idéia de progresso na formação social brasileira: das academias literárias à Sociedade Auxiliadora da Indústria Nacional. Tese de doutorado. Departamento de História/Faculdade de Filosofia, Letras e Ciências Humanas/Universidade de São Paulo, 1999.

PETRONE, Maria Thereza Schorer. A lavoura canavieira em São Paulo. Expansão e declínio (1765-1851). São Paulo: Difusão Européia do Livro, 1968.

PINTO, Virgílio Noya. Balanço das transformações econômicas no século XIX. In.: MOTA, Carlos Guilherme (org.). Brasil em perspectiva. 2. ed. São Paulo: Difusão Européia do Livro, 1969.

PRADO JR., Caio. O fator geográfico na formação e no desenvolvimento da Cidade de São Paulo. In.: Editora Brasiliense, 1966.

PRATT, Mary Louise [et alli]. Literatura e História: perspectivas e convergências. Bauru (SP): EDUSC, 1999. 
Paulo: EDUSC, 1999.

. Os olhos do império: relatos de viagem e transculturação. São

QUINTANEIRO, Tânia. Retratos de mulher: a brasileira vista por viageiros ingleses $e$ norte-americanos durante o século XIX. Rio de Janeiro: Vozes, 1995.

RANGEL, Alberto. Os dois ingleses: Strangford e Stuart. [Rio de Janeiro]: Departamento de Imprensa Nacional, 1972.

RICCI, Maria Lúcia de Souza Rangel; MATOS, Odilon Nogueira. A segunda viagem de Saint-Hilaire a São Paulo. Campinas (SP): Publicações da Academia Campinense de Letras, n. 42, 1982.

RICUPERO, Rubens; OLIVEIRA, Luís Valente de. A Abertura dos Portos. São Paulo: Editora SENAC-SP, 2007.

SAES, Flávio Azevedo Marques de. Estradas de ferro e diversificação da atividade econômica na expansão cafeeira em São Paulo, 1870-1900. In.: SZMRECSÁNYI, Tamás; LAPA, José Roberto do Amaral (orgs.). História econômica da Independência e do Império. 2a. ed. rev. São Paulo: Hucitec/Associação Brasileira de Pesquisadores em História Econômica/Editora da Universidade de São Paulo/Imprensa Oficial, 2002.

SALAZAR, José Monteiro. Araçoiaba \& Ipanema; a história daquela maravilhosa região, desde as forjas de Afonso Sardinha até a Real Fábrica de Ferro, Sorocaba, São Paulo. São Paulo: Ministério da Marinha/IBAMA/Governo do Estado de São Paulo, 1998.

SANTOS, Nilton Pereira dos. A fábrica de ferro São João de Ipanema: economia e política nas últimas décadas do Segundo Reinado (1860-1889). Dissertação de mestrado. Departamento de História/Faculdade de Filosofia, Letras e Ciências Humanas/Universidade de São Paulo, 2009.

SCHWARCZ, Lilia Moritz. O espetáculo das raças: cientistas, instituições e questão racial no Brasil (1870-1930). 5. reimp. São Paulo: Companhia das Letras, 2004.

SEVCENKO, Nicolau. Vislumbrando novas perspectivas. In: Edmund Pink. A São Paulo de Edmund Pink. Trad. e transcr. Cristina Antunes. São Paulo: CBA, 2000.

SILVA, Wilton Carlos Lima da. As terras inventadas: discurso e natureza em Jean de Léry, André João Antonil e Richard Francis Burton. São Paulo: Ed. UNESP, 2003.

SOUZA, Octavio Tarquínio de. Prefácio à $2^{\mathrm{a}}$ edição. In: LIMA, Oliveira. Dom João VI no Brasil. 4. ed. Rio de Janeiro: Topbooks, 2006, pp. 770-775.

SÜSSEKIND, Flora. O Brasil não é longe daqui: o narrador, a viagem. São Paulo: Companhia das Letras, 1990.

TAUNAY, Affonso de E. Collectanea de mappas da cartographia paulista antiga. Abrangendo nove cartas, de 1612 a 1837, reproduzidas da collecção do Museu Paulista e acompanhadas de breves commentarios. São Paulo: Companhia Melhoramentos de S. Paulo, Museu Paulista, 1922.

. Visitantes do Brasil colonial (Séculos XVI-XVIII). 2. ed. São Paulo, Rio de Janeiro, Recife, Porto Alegre: Companhia Editora Nacional, 1938.

TENGARRINHA, José (org.). História de Portugal. 2. ed. rev. ampl. São Paulo: UNESP; Bauru (SP): EDUSC; Portugal: Instituto Camões, 2001. 
TOLEDO, Benedito Lima de. São Paulo: três cidades em um século. 2. ed. aum. São Paulo: Duas Cidades, 1983.

VAINFAS, Ronaldo (org.). Dicionário do Brasil Imperial. Rio de Janeiro: Objetiva, 2002.

VENTURA, Roberto. A saga da cana-de-açúcar. Folha de S. Paulo, São Paulo, 12 abril 2000. Caderno Mais, p. 16-17.

VERBO - Enciclopédia Luso-Brasileira de Cultura. Lisboa: Editorial Verbo, 1960, vol. 2.

VERÍSSIMO, José. Um diplomata da atualidade. In.: LIMA, Oliveira. Formação histórica da nacionalidade brasileira. 3. ed. Rio de Janeiro: Topbooks; São Paulo: Publifolha, 2000, pp. 19-27.

VILLA, Marco Antonio. Um historiador em busca da nacionalidade brasileira. In.: LIMA, Oliveira. Formação histórica da nacionalidade brasileira. 3. ed. Rio de Janeiro: Topbooks; São Paulo: Publifolha, 2000, pp. 261-267.

WETTER, João. A visita do médico sueco dr. Gustavo Beyer ao Brasil no ano de 1813 e a Fábrica de Ferro de Ypanema. Revista do Instituto Histórico e Geográfico de S. Paulo. São Paulo: Typ. do 'Diário Oficial', 1912, vol. XIV, p. 77-102.

WRIGHT, Fernanda de Almeida. Brasil - Estados Unidos. In.: Sérgio Buarque de Holanda (org.). História Geral da Civilização Brasileira. O Brasil monárquico: declínio e queda do império. 5. ed. Rio de Janeiro: Bertrand Brasil, 1995.

\section{Enderecos eletrônicos:}

Anais do Museu Paulista: História e Cultura Material: www.scielo.br

Fundação Biblioteca Nacional: www.bn.br/portal/

Fundação Joaquim Nabuco: www.fundaj.gov.br/geral

História, Ciência, Saúde - Manguinhos: www.scielo.br

História (São Paulo): www.scielo.br

Library of Congress online catalog: http://catalog.loc.gov

Portal dos Sistemas de Bibliotecas das Universidades Estaduais Paulistas:

http://bibliotecas-cruesp.usp.br/unibibliweb/

Revista de Economia Política e História Econômica: http://rephe01.googlepages.com

Revista Eletrônica de Jornalismo Científico: http://www.comciencia.br e http://www.labjor.unicamp.br

Sistema de Bibliotecas da PUC: http://lumen.pucsp.br

Sistema de Bibliotecas da Unicamp: www.unicamp.br/bc/

Sistema de Biblioteca da USP:

http://dedalus.usp.br:4500/ALEPH/por/USP/USP/DEDALUS/START

The British Library: www.bl.uk 
ANEXO I - "O território da capitania de São Paulo, de 1700 a 1853”
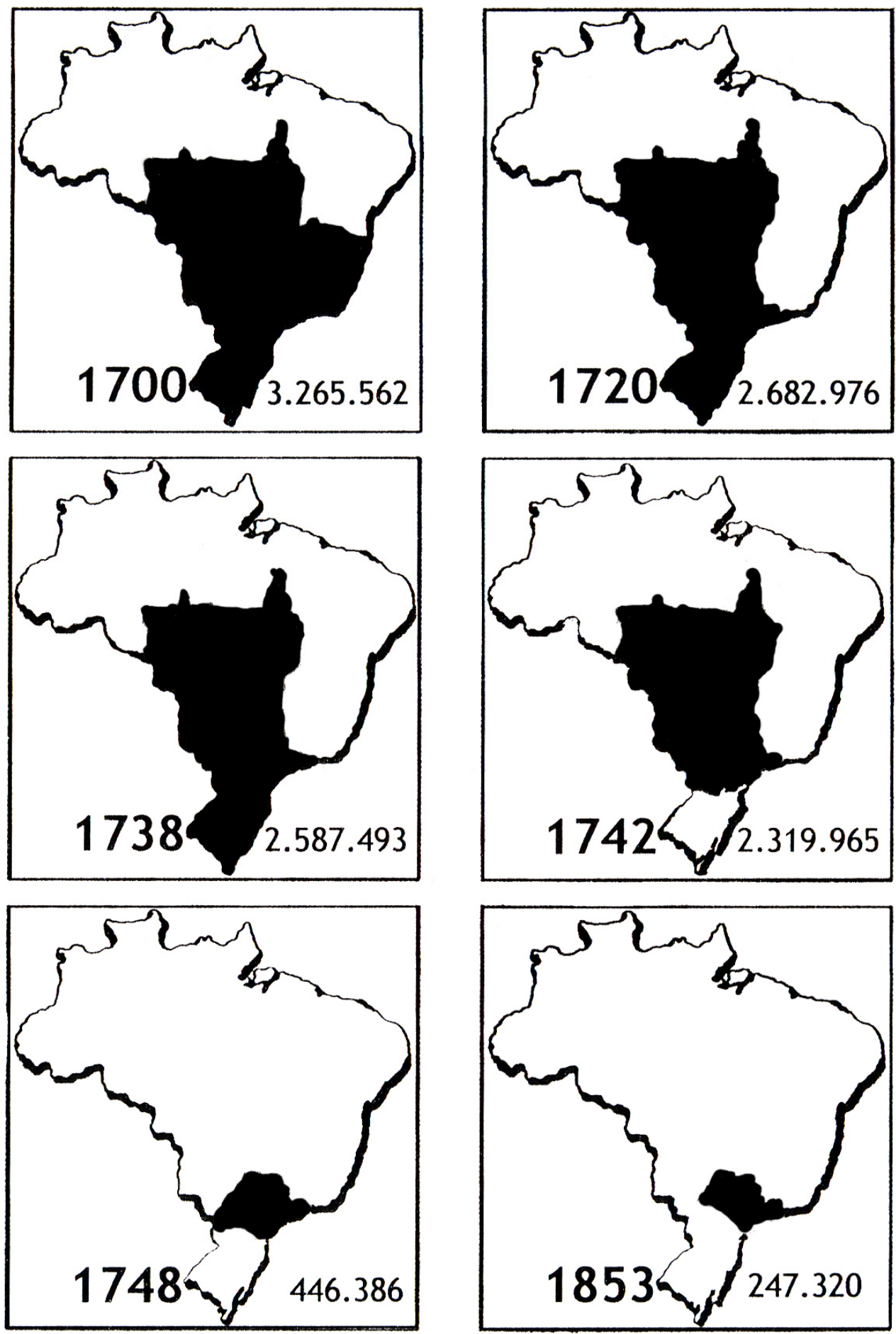

FONTE: Honório de Sylos. São Paulo e seus caminhos. São Paulo: McGraw-Hill, 1976, p. 7. apud. Maria Lucília Viveiros Araújo. Os caminhos da riqueza dos paulistanos na primeira metade do oitocentos. São Paulo: Hucitec: FAPESP, 2006, p. 22.

NOTA: Os valores apresentados no mapa correspondem à área de extensão da capitania paulista em quilômetros quadrados. 
